MARIZILDA MAGRO

\title{
Aspectos da Pesca e Dinâmica de Populações do espada, Trichiurus lepturus (Trichiuridae, Teleostei), da costa Sudeste-Sul do Brasil.
}

Tese apresentada ao Instituto Oceanográfico da Universidade de São Paulo, como parte dos requisitos para a obtenção do título de Doutor em Ciências, área de Oceanografia Biológica.

Orientador: Prof. Dr. Miguel Petrere Jr.

Co-orientador: Prof. Dr. Alexandre W. Silva Hilsdorf 
Universidade de São Paulo

Instituto Oceanográfico

Aspectos da Pesca e Dinâmica de Populações do espada, Trichiurus lepturus (Trichiuridae, Teleostei), da costa Sudeste-Sul do Brasil.

\section{MARIZILDA MAGRO}

Tese apresentada ao Instituto Oceanográfico da Universidade de São Paulo, como parte dos requisitos para obtenção do título de Doutor em Ciências, área de Oceanografia Biológica.

Julgada em

Prof. Dr.

Conceito

Prof. Dr.

Conceito

Prof. Dr.

Conceito

Prof. Dr.

Conceito

Prof. Dr.

Conceito 
Melhor, porém, do que o sacrifício de objetos e coisas, é o sacrifício oferecido pelo saber. O saber em si mesmo é o coroamento de todas as ações... 
A você... Maria ... que me deu a luz e que ainda me ilumina.... A você Ricardo... que me mostra o quanto posso, mesmo que eu não queira ver.... 


\section{ÍNDICE}

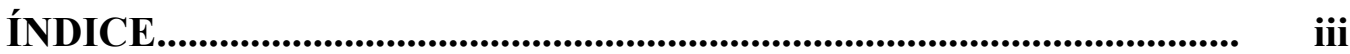

ÍNDICE DE TABELAS................................................................... v

ÍNDICE DE FIGURAS.......................................................................

AGRADECIMENTOS................................................................................

RESUMO........................................................................................................ xvii

ABSTRACT ..............................................................................................

I. INTRODUÇÃO......................................................................................... 1

II. CARACTERIZAÇÃO DA ÁREA DE ESTUDO.................................. 7

III. OBJETIVOS...................................................................................

IV. METODOLOGIA................................................................................ 9

1. Obtenção de dados estatísticos das pescarias......................................... 9

2. Obtenção de dados em campo..................................................................... 10

3. Obtenção de dados em laboratório........................................................... 13

4. Análise de dados............................................................................................... 14

4.1. Dados estatístico-pesqueiros............................................................... 14

4.2. Diversidade genética intra e inter populacional.................................. 15

4.3. Dados merísticos............................................................................. 18

4.4. Estrutura de comprimentos............................................................... 18

4.5. Relações Biométricas........................................................................... 19

4.6. Reprodução..................................................................................... 20

4.7. Idade e Crescimento.......................................................................... 22

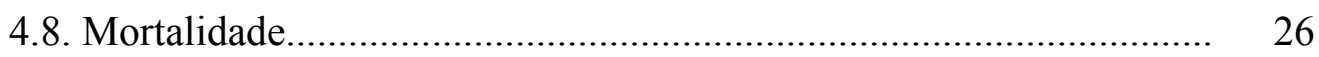

4.9. Rendimento e Biomassa Relativos por Recruta.................................. 28 


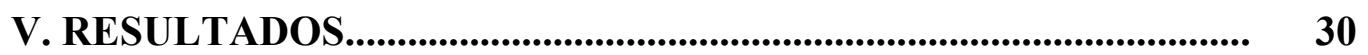

1. Dados estatístico-pesqueiros.......................................................... 30

2. Diversidade genética intra e inter populacional................................. 32

3. Dados merísticos......................................................................... 33

4. Estrutura de comprimentos............................................................ 34

5. Relações Biométricas..................................................................... 35

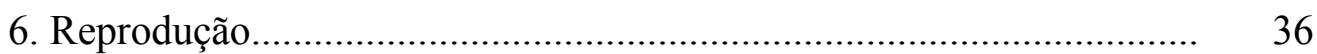

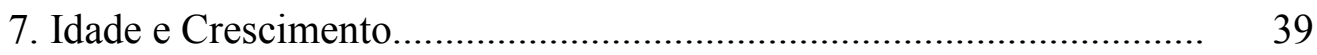

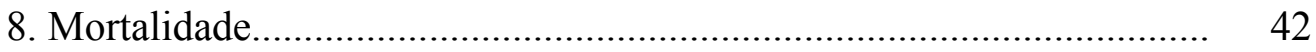

9. Rendimento e Biomassa Relativos por Recruta................................... 44

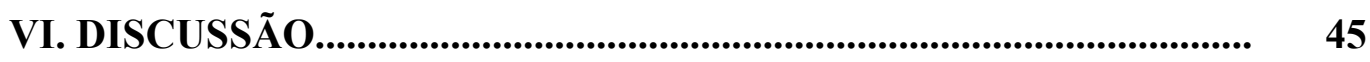

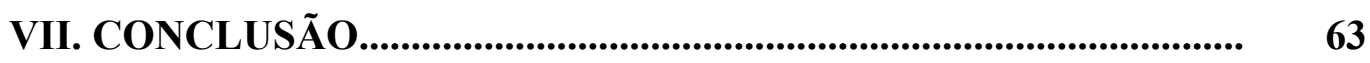

VIII. BIBLIOGRAFIA................................................................................... 65

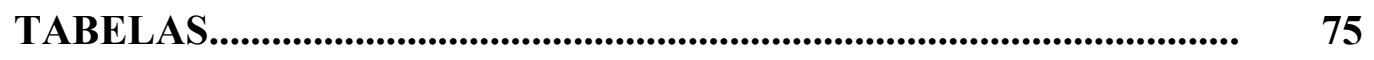

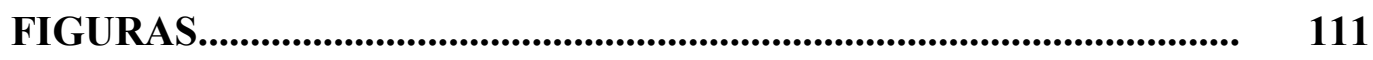

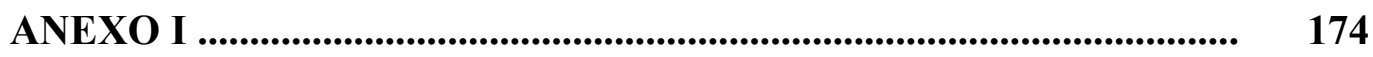




\section{ÍNDICE DE TABELAS}

Tabela 01: Produção pesqueira anual das principais espécies capturadas na região de Arraial do Cabo (RJ) no período de 1992 a 2002, fornecida por MSc. Paulo José de Azevedo Silva (FIPAC).

Tabela 02: Dados de desembarques de todas as artes de pesca que apresentaram T. lepturus em suas capturas, fornecidos pelo Instituto de Pesca-SP.

Tabela 03: Participação relativa de Trichiurus lepturus ao nível explicativo de $80 \%$ na arte de pesca de linha-de-mão e arrasto de fundo com parelhas desenvolvidas na costa de São Paulo, no período de 1998 a 2004.

Tabela 04: Produção pesqueira mensal das principais espécies capturadas em três cercos flutuantes localizados na região de Porto Belo (SC), de propriedade da Empresa Pioneira da Costa S.A., no período de maio de 2002 a abril de 2003.

Tabela 05: A - Análise molecular de variância (AMOVA) dos 108 exemplares de T. lepturus. B Tabela de Фst pareado. Entre parenteses - não significativamente diferente de zero. 1 Belém (PA), 2 - Natal (RN), 3 - Arraial do Cabo (RJ), 4 - Guarujá (SP), 5 - Porto Belo (SC), 6 - Rio Grande (RS).

Tabela 06: Matriz de distâncias genéticas (acima da diagonal) e de identidade (abaixo da diagonal) de Nei (1978) com correção de Lynch \& Milligan (1994) para as regiões pareadas. 1 Belém (PA), 2 - Natal (RN), 3 - Arraial do Cabo (RJ), 4 - Guarujá (SP), 5 - Porto Belo (SC), 6 - Rio Grande (RS).

Tabela 07: Descrição das amostras de número de raios da primeira nadadeira dorsal dos exemplares de T. lepturus de cada região amostrada, por sexo. RJF e RJM - fêmeas e machos do Rio de Janeiro; SPF e SPM - fêmeas e machos de São Paulo; SCF e SCM - fêmeas e machos de Santa Catarina; n - número da amostra; dp - desvio padrão; Min e Max - limites da amplitude dos dados; stg1 - simetria estandartizada; stg2 - curtose estandartizada.

Tabela 08: Probabilidades dos testes de variância (teste F), testes de igualdade de médias (teste t), teste de homocedasticidade (Bartlett) e de comparação de medianas (Kruskal-Wallis) para o número de raios da segunda nadadeira dorsal dos exemplares de T. lepturus. RJF e RJM fêmeas e machos do Rio de Janeiro; SPF e SPM - fêmeas e machos de São Paulo; SCF e SCM - fêmeas e machos de Santa Catarina. * Diferença significativa ao nível de significância de $5 \%$.

Tabela 09: Teste de comparação múltipla não-paramétricos a posteriori para dados desbalanceados aplicado aos dados de número de raios da segunda nadadeira dorsal de T. lepturus dos grupos de diferentes Estados.

Tabela 10: Descrição das amostras de comprimento total $(\mathrm{Lt}-\mathrm{mm})$ dos exemplares de T. lepturus de cada região amostrada, por sexo. RJF e RJM - fêmeas e machos do Rio de Janeiro; SPF e SPM - fêmeas e machos de São Paulo; SCF e SCM - fêmeas e machos de Santa Catarina; n - número da amostra; dp - desvio padrão; Min e Max - limites da amplitude dos dados; stg1 - simetria estandartizada; stg2 - curtose estandartizada.

Tabela 11: Descrição das amostras de peso total $(\mathrm{Wt}-\mathrm{g})$ dos exemplares de T. lepturus de cada região amostrada, por sexo. RJF e RJM - fêmeas e machos do Rio de Janeiro; SPF e SPM fêmeas e machos de São Paulo; SCF e SCM - fêmeas e machos de Santa Catarina; n número da amostra; dp - desvio padrão; Min e Max - limites da amplitude dos dados; stg1 simetria estandartizada; stg2 - curtose estandartizada. 
Tabela 12: Parâmetros da relação potencial $\left(y=a \cdot x^{b}\right)$ entre comprimento anal e comprimento total dos exemplares de $T$. lepturus por sexo e agrupados obtidos para os diferentes Estados analisados e seus respectivos desvios padrão (parênteses). RJF, RJM e RJ - fêmeas, machos e agrupados do Rio de Janeiro; SPF, SPM e SP - fêmeas, machos e agrupados de São Paulo; SCF, SCM e SC - fêmeas, machos e agrupados de Santa Catarina; a - intercepto; b inclinação; $\mathrm{r}^{2}$ - coeficiente de determinação; $\mathrm{n}$ - número amostral.

Tabela 13: Parâmetros da relação potencial $\left(y=a \cdot x^{b}\right)$ entre comprimento total e comprimento anal dos exemplares de T. lepturus por sexo e agrupados obtidos para os diferentes Estados analisados e seus respectivos desvios padrão (parênteses). RJF, RJM e RJ - fêmeas, machos e agrupados do Rio de Janeiro; SPF, SPM e SP - fêmeas, machos e agrupados de São Paulo; SCF, SCM e SC - fêmeas, machos e agrupados de Santa Catarina; a - intercepto; b inclinação; $\mathrm{r}^{2}$ - coeficiente de determinação; $\mathrm{n}$ - número amostral.

Tabela 14 - Análise de covariância dos modelos relacionando comprimento total (variável dependente) e sexo (variável categórica) e comprimento anal (covariável), nos diferentes Estados analisados.

Tabela 15: Parâmetros da relação potencial $\left(y=a \cdot x^{b}\right)$ entre peso total e comprimento total dos exemplares de $T$. lepturus por sexo e agrupados obtidos para os diferentes Estados analisados e seus respectivos desvios padrão (parênteses). RJF, RJM e RJ - fêmeas, machos e agrupados do Rio de Janeiro; SPF, SPM e SP - fêmeas, machos e agrupados de São Paulo; SCF, SCM e SC - fêmeas, machos e agrupados de Santa Catarina; a - intercepto; b inclinação; $r^{2}$ - coeficiente de determinação; $n$ - número amostral.

Tabela 16: Níveis de significância (P) do teste de $\chi^{2}$ da razão de verossimilhança máxima para as diversas hipóteses de comparação entre as curvas resultantes do modelo potencial entre peso total e comprimento total. Curvas: hipótese de curvas coincidentes; a: hipótese de igualdade de interceptos; b: hipótese de igualdade de inclinações. *Diferenças significativas com $\mathrm{P}<0,05$.

Tabela 17: Número de exemplares por sexo de Trichiurus lepturus coletados mensalmente nos diferentes Estados.

Tabela 18: Comprimentos totais e anais médios de primeira maturação gonadal $\left(\mathrm{L}_{50}\right)$ de $T$. lepturus em cada Estado analisado.

Tabela 19: Níveis de significância $(\mathrm{P})$ do teste de $\chi^{2}$ da razão de verossimilhança máxima para as diversas hipóteses de comparação entre as curvas de freqüência relativa acumulada de fêmeas e machos adultos por classe de comprimento total $(\mathrm{mm})$. Curvas: hipótese de curvas coincidentes; L50: hipótese de igualdade de pontos de inflecção das curvas; r: hipótese de igualdade de coeficientes de curvatura. * Diferenças significativas com $\mathrm{P}<0,05$.

Tabela 20: Níveis de significância (P) do teste de $\chi^{2}$ da razão de verossimilhança máxima para as diversas hipóteses de comparação entre as curvas resultantes do modelo potencial entre fecundidade e as variáveis de peso total e comprimento total dos Estados de São Paulo e Santa Catarina. Curvas: hipótese de curvas coincidentes; a: hipótese de igualdade de interceptos; b: hipótese de igualdade de inclinações. * Diferenças significativas com $\mathrm{P}<0,05$.

Tabela 21: Número analisado de otólitos de fêmeas (F) e machos (M) por classe de comprimento e bimestre de T. lepturus amostrados em Arraial do Cabo (RJ).

Tabela 22: Número analisado de otólitos de fêmeas (F) e machos (M) por classe de comprimento e bimestre de T. lepturus amostrados no Guarujá (SP). 
Tabela 23: Número analisado de otólitos de fêmeas (F) e machos (M) por classe de comprimento e bimestre de T. lepturus amostrados em Porto Belo (SC).

Tabela 24: Descrição de amostras de comprimento (Lo $-\mathrm{mm}$ ), altura (Ho $-\mathrm{mm}$ ) e peso (Wo $-\mathrm{g}$ ) dos otólitos esquerdo (E) e direito (D) por sexo de T. lepturus da região de Arraial do Cabo (RJ). $\mathrm{n}$ - número da amostra; dp - desvio padrão; Min e Max - limites da amplitude dos dados; stg1 - simetria estandartizada; stg2 - curtose estandartizada.

Tabela 25: Descrição de amostras de comprimento (Lo $-\mathrm{mm})$, altura (Ho $-\mathrm{mm})$ e peso (Wo $-\mathrm{g})$ dos otólitos esquerdo (E) e direito (D) por sexo de T. lepturus da costa de São Paulo. n número da amostra; dp - desvio padrão; Min e Max - limites da amplitude dos dados; stg1 simetria estandartizada; stg2 - curtose estandartizada.

Tabela 26: Descrição de amostras de comprimento (Lo $-\mathrm{mm})$, altura (Ho $-\mathrm{mm})$ e peso (Wo $-\mathrm{g})$ dos otólitos esquerdo (E) e direito (D) por sexo de T. lepturus da região de Porto Belo (SC). $\mathrm{n}$ - número da amostra; dp - desvio padrão; Min e Max - limites da amplitude dos dados; stg1 - simetria estandartizada; stg2 - curtose estandartizada.

Tabela 27: Níveis de significância dos testes t (t) ou Wilcoxon-Mann-Whitney (W) pareados para o comprimento (Lo), altura (Ho) e peso (Wo) dos otólitos direito e esquerdo de fêmeas e machos de T. lepturus. RJ - Rio de Janeiro; SP - São Paulo; SC - Santa Catarina. * Diferença significativa ao nível de significância de $5 \%$.

Tabela 28: Parâmetros da relação linear $\left(y=a+b^{*} x\right)$ entre comprimento do otólito e comprimento total dos exemplares de T. lepturus por sexo obtidos para os diferentes Estados analisados e seus respectivos desvios padrão (parênteses). RJF e RJM - fêmeas e machos do Rio de Janeiro; SPF e SPM - fêmeas e machos de São Paulo; SCF e SCM - fêmeas e machos de Santa Catarina; $\mathrm{a}$ - intercepto; $\mathrm{b}$ - inclinação; $\mathrm{r}^{2}$ - coeficiente de determinação; $\mathrm{n}$ - número amostral.

Tabela 29: Níveis de significância da análise de covariância (ANCOVA) das inclinações (Pb) e interceptos $(\mathrm{Pa})$ das relações lineares entre comprimento do otólito e comprimento total, e respectivos parâmetros comuns. * Diferenças significativas com $\mathrm{P}<0,05$.

Tabela 30: Parâmetros da relação linear $\left(y=a+b^{*} x\right)$ entre altura do otólito e comprimento total dos exemplares de T. lepturus por sexo obtidos para os diferentes Estados analisados e seus respectivos desvios padrão (parênteses). RJF e RJM - fêmeas e machos do Rio de Janeiro; SPF e SPM - fêmeas e machos de São Paulo; SCF e SCM - fêmeas e machos de Santa Catarina; $\mathrm{a}$ - intercepto; $\mathrm{b}$ - inclinação; $\mathrm{r}^{2}$ - coeficiente de determinação; $\mathrm{n}$ - número amostral.

Tabela 31: Níveis de significância da análise de covariância (ANCOVA) das inclinações (Pb) e interceptos $(\mathrm{Pa})$ das relações lineares entre altura do otólito e comprimento total, e respectivos parâmetros comuns. * Diferenças significativas com $\mathrm{P}<0,05$.

Tabela 32: Parâmetros da relação potencial $\left(y=\mathrm{a}^{*} \mathrm{x}^{\mathrm{b}}\right)$ entre peso do otólito e comprimento total dos exemplares de T. lepturus por sexo obtidos para os diferentes Estados analisados e seus respectivos desvios padrão (parênteses). RJF e RJM - fêmeas e machos do Rio de Janeiro; SPF e SPM - fêmeas e machos de São Paulo; SCF e SCM - fêmeas e machos de Santa Catarina; $\mathrm{a}$ - intercepto; $\mathrm{b}$ - inclinação; $\mathrm{r}^{2}-$ coeficiente de determinação; $\mathrm{n}$ - número amostral.

Tabela 33: Níveis de significância (P) do teste de $\chi^{2}$ da razão de verossimilhança máxima para as diversas hipóteses de comparação entre as curvas resultantes do modelo potencial entre peso do otólito e comprimento total. Curvas: hipótese de curvas coincidentes; a: hipótese de igualdade de interceptos; b: hipótese de igualdade de inclinações. * Diferenças significativas com $\mathrm{P}<0,05$. 
Tabela 34: Número de exemplares de $T$. lepturus obtido por número de anéis de crescimento nas secções dos otólitos, por sexo de cada Estado analisado.

Tabela 35: Descrição de amostras dos resíduos dos modelos linear (Lin), potencial (Pot) e logístico ( $\mathrm{Log})$ entre comprimento total $(\mathrm{mm})$ e raio do otólito $(\mathrm{mm})$ por sexo de T. lepturus da região de Arraial do Cabo (RJ). n - número da amostra; dp - desvio padrão; Min e Max - limites da amplitude dos dados; stg1 - simetria estandartizada; stg2 - curtose estandartizada.

Tabela 36: Descrição de amostras dos resíduos dos modelos linear (Lin), potencial (Pot) e logístico $(\mathrm{Log})$ entre comprimento total $(\mathrm{mm})$ e raio do otólito $(\mathrm{mm})$ por sexo de T. lepturus da costa de São Paulo. $\mathrm{n}$ - número da amostra; dp - desvio padrão; Min e Max - limites da amplitude dos dados; stg1 - simetria estandartizada; stg2 - curtose estandartizada.

Tabela 37: Descrição de amostras dos resíduos dos modelos linear (Lin), potencial (Pot) e logístico $(\mathrm{Log})$ entre comprimento total $(\mathrm{mm})$ e raio do otólito $(\mathrm{mm})$ por sexo de T. lepturus da região de Porto Belo (SC). n - número da amostra; dp - desvio padrão; Min e Max - limites da amplitude dos dados; stg1 - simetria estandartizada; stg2 - curtose estandartizada.

Tabela 38: Parâmetros das curvas do modelo logístico $\left(\mathrm{y}=\left(\mathrm{a} / 1+\mathrm{b}^{*} \mathrm{c}^{\mathrm{x}}\right)\right.$ entre comprimento total e raio do otólito dos exemplares de T. lepturus por sexo e agrupados obtidos para os diferentes Estados analisados e seus respectivos desvios padrão (parênteses). RJF, RJM e RJ - fêmeas, machas e agrupadas do Rio de Janeiro; SPF, SPM e SP - fêmeas, machos e agrupados de São Paulo; SCF, SCM e SC - fêmeas, machos e agrupados de Santa Catarina; a - intercepto; $\mathrm{b}$ - inclinação; $\mathrm{r}^{2}$ - coeficiente de determinação; $\mathrm{n}$ - número amostral.

Tabela 39: Comprimento total médio por classe etária para os conjuntos OtolMed (otólitos) e RetroMed (retrocalculados) por sexo e agrupados de T. lepturus da região de Arraial do Cabo (RJ) (n - número de exemplares por classe etária; Ltmed - comprimento médio.

Tabela 40: Comprimento total médio por classe etária para os conjuntos OtolMed (otólitos) e RetroMed (retrocalculados) por sexo e agrupados de T. lepturus da costa de São Paulo (n número de exemplares por classe etária; Ltmed - comprimento médio.

Tabela 41: Comprimento total médio por classe etária para os conjuntos OtolMed (otólitos) e RetroMed (retrocalculados) por sexo e agrupados de T. lepturus da região de Porto Belo (SC) ( $\mathrm{n}$ - número de exemplares por classe etária; Ltmed - comprimento médio

Tabela 42: Parâmetros do modelo de crescimento de von Bertalanffy estimados para os conjuntos OtolTot, OtolMed, RetroTot e RetroMed, e seus respectivos desvios padrão (parênteses), coeficientes de determinação $\left(\mathrm{r}^{2}\right)$, número amostral $(\mathrm{n})$, índices de performance de crescimento $(\phi ')$ e pesos assintóticos $\left(\mathrm{W}_{\mathrm{oo}}\right)$, dos exemplares de T. lepturus da região de Arraial do Cabo (RJ).

Tabela 43: Parâmetros do modelo de crescimento de von Bertalanffy estimados para os conjuntos OtolTot, OtolMed, RetroTot e RetroMed, e seus respectivos desvios padrão (parênteses), coeficientes de determinação $\left(\mathrm{r}^{2}\right)$, número amostral $(\mathrm{n})$, índices de performance de crescimento $\left(\phi^{\prime}\right)$ e pesos assintóticos $\left(\mathrm{W}_{\mathrm{oo}}\right)$, dos exemplares de T. lepturus da costa de São Paulo.

Tabela 44: Parâmetros do modelo de crescimento de von Bertalanffy estimados para os conjuntos OtolTot, OtolMed, RetroTot e RetroMed, e seus respectivos desvios padrão (parênteses), coeficientes de determinação $\left(\mathrm{r}^{2}\right)$, número amostral $(\mathrm{n})$, índices de performance de crescimento $\left(\boldsymbol{\phi}\right.$ ') e pesos assintóticos $\left(\mathrm{W}_{\mathrm{oo}}\right)$, dos exemplares de T. lepturus da região de Porto Belo (SC). 
Tabela 45: Níveis de significância $(\mathrm{P})$ do teste de $\chi^{2}$ da razão de verossimilhança máxima para as diversas hipóteses de comparação entre as curvas resultantes do modelo de crescimento de von Bertalanffy dos conjuntos OtolTot e RetroTot por sexo de cada Estado. Curvas: hipótese de curvas coincidentes; $\mathrm{L}_{\mathrm{oo}}$ : hipótese de igualdade de comprimentos assintóticos; $\mathrm{k}$ : hipótese de igualdade de taxas de crescimento; $\mathrm{t}_{0}$ : hipótese de igualdade de idade teórica no comprimento zero; $\mathrm{L}_{\mathrm{oo}}-\mathrm{k}$ : hipótese de igualdade de $\mathrm{L}_{\mathrm{oo}}$ e $\mathrm{k} ; \mathrm{L}_{\mathrm{oo}}-\mathrm{t}_{0}$ : hipótese de igualdade

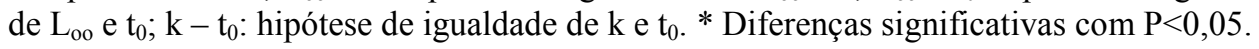

Tabela 46: Parâmetros do modelo de crescimento de von Bertalanffy estimados para sexos agrupados do conjunto OtolTot de cada Estado, e seus respectivos desvios padrão (parênteses), coeficientes de determinação $\left(\mathrm{r}^{2}\right)$, número amostral (n), índices de performance de crescimento $\left(\phi^{\prime}\right)$ e pesos assintóticos $\left(\mathrm{W}_{\mathrm{oo}}\right)$.

Tabela 47: Níveis de significância (P) do teste de $\chi^{2}$ da razão de verossimilhança máxima para as diversas hipóteses de comparação entre as curvas resultantes do modelo de crescimento de von Bertalanffy do conjunto OtolTot entre sexos e agrupados de cada Estado. Curvas: hipótese de curvas coincidentes; $\mathrm{L}_{\mathrm{oo}}$ : hipótese de igualdade de comprimentos assintóticos; $\mathrm{k}$ : hipótese de igualdade de taxas de crescimento; $\mathrm{t}_{0}$ : hipótese de igualdade de idade teórica no comprimento zero; $\mathrm{L}_{\mathrm{oo}}-\mathrm{k}$ : hipótese de igualdade de $\mathrm{L}_{\mathrm{oo}}$ e $\mathrm{k} ; \mathrm{L}_{\mathrm{oo}}-\mathrm{t}_{0}$ : hipótese de igualdade

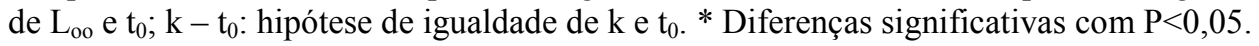

Tabela 48: Chave idade-comprimento por sexo e agrupados obtida para os exemplares da região de Arraial do cabo $(\mathrm{RJ})$.

Tabela 49: Chave idade-comprimento por sexo e agrupados obtida para os exemplares da costa de São Paulo.

Tabela 50: Chave idade-comprimento por sexo e agrupados obtida para os exemplares da região de Porto Belo (SC).

Tabela 51: Total capturado no dia de coleta de dados de campo de T. lepturus na Prainha (Arraial do Cabo, RJ), no período de janeiro de 2002 a julho de 2003.

Tabela 52: Produção mensal de T. lepturus na costa de São Paulo capturada com arrasto de fundo com parelhas (fonte Instituto de Pesca/ APTA/SAA/SP). Em negrito o período de amostragem deste trabalho.

Tabela 53: Taxas de mortalidade total (Z) obtidas para T. lepturus pelos métodos de Curva de Captura e de Ssentongo \& Larkin, e respectivas taxas de sobrevivência (S).

Tabela 54: A: Estimadores de parâmetros utilizados para o cálculo de mortalidade natural dos diversos modelos propostos. $\mathrm{L}_{\mathrm{oo}}=$ comprimento máximo assintótico $(\mathrm{em} \mathrm{cm}) ; \mathrm{k}=$ taxa de crescimento $\left(\mathrm{ano}^{-1}\right) ; \mathrm{t}_{0}=$ idade teórica no comprimento zero (anos); $\mathrm{T}\left({ }^{\circ} \mathrm{C}\right)=$ temperatura média anual da água; Tmáx = longevidade (anos); $\mathrm{T}_{50}=$ idade de primeira maturação sexual. B: Taxas de mortalidade natural (M) obtidas por diversos métodos para T. lepturus de cada Estado analisado.

Tabela 55: Taxas de mortalidade por pesca (F - /ano) e taxas de explotação obtidas para T. lepturus em cada Estado, para as diferentes estimativas de taxa de mortalidade.

Tabela 56: Taxas de explotação $\mathrm{E}_{\max }$ e $\mathrm{E}_{0.1}$ e taxas de mortalidade por pesca $\mathrm{F}_{\max }$ e $\mathrm{F}_{0.1}$ obtidas para T. lepturus em cada Estado, utilizando-se a taxa de mortalidade natural do modelo empírico de Pauly. 


\section{ÍNDICE DE FIGURAS}

Figura 01: Espada Trichiurus lepturus (Linnaeus, 1758) (Trichiuridae, Teleostei)

Figura 02: Área de distribuição da espécie Trichiurus lepturus na região sudeste-sul do Brasil ( em azul) e pontos de coleta de amostras (*)

Figura 03: Pesca artesanal de linha de mão - Arraial do Cabo (RJ)

Figura 04: Pescadores pesando a produção de pescado em caixas de até $20 \mathrm{~kg}$,

Figura 05: Pescador limpando os peixes a céu aberto para retirada dos filés,

Figura 06: Arrasto de praia noturno - Prainha - Arraial do Cabo (RJ)

Figura 07: Obtenção dos dados biométricos em campo - Arraial do Cabo (RJ)

Figura 08: Barco da parelha Cigano do Mar III e Cigano do Mar IV - Guarujá (SP)

Figura 09: Pescado passando pela pré-lavagem no momento da descarga - Itafish Guarujá (SP)

Figura 10: Triagem das espécies para comercialização - Itafish - Guarujá (SP)

Figura 11: Cerco flutuante da Praia do Estaleiro - Porto Belo (SC)

Figura 12: Canoa fechando a boca da rede de cerco (círculo menor - bóias vermelhas) Porto belo (SC)

Figura 13: Detalhe da boca da rede de cerco flutuante

Figura 14: Procedimento de despesca da rede de cerco flutuante - Porto Belo (SC)

Figura 15: Pescadores trazendo o capturado para o interior da chata "Katu" - Porto Belo (SC)

Figura 16: Formas para acondicionamento do espada em freezer - Pioneira da Costa S,A,

Figura 17: Acondicionamento dos espadas nas formas metálicas para congelamento Pioneira da Costa S.A.

Figura 18: Corte dos blocos de espada congelados para transporte e comercialização

Figura 19: Caixa para acondicionamento e transporte do produto

Figura 20: Captura e esforço de pesca anuais, verificados no período de 1992 a 2002 na região de Arraial do Cabo (RJ),

Figura 21: Captura por unidade de esforço (CPUE) anual da pesca em Arraial do Cabo (RJ) e respectivos desvios da média, no período de 1992 a 2002,

Figura 22: Proporção das principais espécies na captura anual de Arraial do Cabo (RJ), no período de 1992 a 2002,

Figura 23: Produção anual de Trichiurus lepturus e respectivas proporções do total capturado no período de 1992 a 2002, na região de Arraial do Cabo (RJ). 
Figura 24: Captura por unidade de esforço (CPUE) anual de Trichiurus lepturus da região de Arraial do Cabo (RJ) e respectivos desvios da média, no período de 1992 a 2002,

Figura 25: Produção total anual desembarcada em São Paulo (em kg) e respectivas proporções de T. lepturus no período 1998-2004.

Figura 26: Proporções mensais de T. lepturus na captura total desembarcada em São Paulo no período 1998-2004.

Figura 27: Proporções mensais de T. lepturus na captura anual da espécie desembarcada em São Paulo no período 1998-2004.

Figura 28: Número de desembarques realizados em São Paulo com presença de $T$. lepturus por arte de pesca no período de 1998-2004. Dados disponibilizados pelo Instituto de Pesca/APTA/SAA/SP.

Figura 29: Captura (em kg) de T. lepturus em cada arte de pesca e respectivas porcentagens do total capturado em São Paulo no período de 1998-2004.

Figura 30: Participação relativa de T. lepturus por desembarque de pesca comercial de arrasto de fundo com parelhas efetuados em São Paulo no período de 1998-2004.

Figura 31: Participação relativa de T. lepturus por desembarque de pesca artesanal de linha-de-mão efetuados em São Paulo no período de 1998-2004.

Figura 32: Boxplot das capturas trimestrais de T. lepturus provenientes da pesca de arrasto de fundo com parelhas em São Paulo no período de 1998 a 2004.

Figura 33: Boxplot do esforço de pesca trimestral aplicado nas operações de pesca de arrasto de fundo com parelhas em São Paulo que apresentaram T. lepturus no período de 1998 a 2004

Figura 34: Boxplot da CPUE trimestral de T. lepturus capturado na pesca de arrasto de fundo com parelhas em São Paulo no período de 1998 a 2004.

Figura 35: Variação trimestral da mediana das capturas de T. lepturus na pesca de arrasto de fundo com parelhas de São Paulo, em relação à sua média no período de 1998 a 2004.

Figura 36: Variação trimestral da mediana do esforço de pesca aplicado trimestralmente na pesca de arrasto de fundo com parelhas de São Paulo que apresentaram $T$. lepturus, em relação à sua média no período de 1998 a 2004.

Figura 37: Variação trimestral da mediana da CPUE de T. lepturus na pesca de arrasto de fundo com parelhas de São Paulo, em relação à sua média no período de 1998 a 2004.

Figura 38: Produção mensal $(\mathrm{kg})$ e esforço de pesca (dias) dos cercos flutuantes situados nas praias de Caixa D'aço e Estaleiro, em Porto Belo (SC), de propriedade da Empresa Pioneira da Costa S.A., no período de maio de 2002 a abril de 2003.

Figura 39: Proporção mensal das espécies capturadas nos cercos flutuantes situados nas praias de Caixa D'aço e Estaleiro, em Porto Belo (SC), de propriedade da Empresa Pioneira da Costa S.A., no período de maio de 2002 a abril de 2003.

Figura 40: Produção mensal de T. lepturus $(\mathrm{kg})$ e proporção da espécie na captura total obtida nos cercos flutuantes situados nas praias de Caixa D'aço e Estaleiro, em Porto Belo (SC), de propriedade da Empresa Pioneira da Costa S.A., no período de maio de 2002 a abril de 2003. 
Figura 41: Captura por umidade de esforço (CPUE - kg/dia) e respectivas variações da média do período dos cercos flutuantes situados nas praias de Caixa D’aço e Estaleiro, em Porto Belo (SC), de propriedade da Empresa Pioneira da Costa S.A., no período de maio de 2002 a abril de 2003.

Figura 42: Extração de várias amostras de DNA de T. lepturus, apresentando os rastros de degradação do DNA a diferentes concentrações.

Figura 43: Eletroforese das amplificações RAPD-PCR das amostras de DNA de tecido muscular de $T$, lepturus, com o primer Primer 01, nos Estados do Pará, Rio Grande do Norte e Rio de Janeiro, São Paulo, Santa Catarina e Rio Grande do Sul.

Figura 44 - Dendrograma de similaridade genética com o coeficiente de Jaccard e algoritmo UPGMA obtido para as amostras de T. lepturus das seis regiões analisadas.

Figura 45: Dendrograma de distâncias genéticas de Ney (1978) e algoritmo UPGMA obtido para T. lepturus em cada região. 1 - Belém (PA), 2 - Natal (RN), 3 Arraial do Cabo (RJ), 4 - Guarujá (SP), 5 - Porto Belo (SC), 6 - Rio Grande (RS).

Figura 46 - Distribuição mensal de freqüências relativas de comprimento anal dos exemplares Trichiurus lepturus amostrados em Arraial do Cabo (RJ).

Figura 47 - Distribuição mensal de freqüências relativas de comprimento anal dos exemplares Trichiurus lepturus amostrados em Guarujá (SP).

Figura 48 - Distribuição mensal de freqüências relativas de comprimento anal dos exemplares Trichiurus lepturus amostrados em Porto Belo e Florianópolis (SC).

Figura 49: Boxplot dos comprimentos totais $(\mathrm{Lt}-\mathrm{mm})$ de $T$. lepturus por sexo de cada região estudada. RJF e RJM - fêmeas e machos do Rio de Janeiro; SPF, SPI e SPM - fêmeas, indeterminados e machos de São Paulo; SCF, SCI e SCM fêmeas, indeterminados e machos de Santa Catarina

Figura 50: Boxplot dos pesos totais $(\mathrm{Wt}-\mathrm{g})$ de T. lepturus por sexo de cada região estudada. RJF e RJM - fêmeas e machos do Rio de Janeiro; SPF, SPI e SPM fêmeas, indeterminados e machos de São Paulo; SCF, SCI e SCM - fêmeas, indeterminados e machos de Santa Catarina.

Figura 51: Relações entre o comprimento anal e comprimento total dos exemplares fêmeas (RJ -Fem), machos (RJ - Mac) e sexos agrupados (RJ) de T. lepturus da região de Arraial do Cabo (RJ), e seus respectivos diagramas de dispersão de resíduos.

Figura 52: Relações entre o comprimento total e comprimento anal dos exemplares fêmeas (RJ -Fem), machos (RJ - Mac) e sexos agrupados (RJ) de T. lepturus da região de Arraial do Cabo (RJ), e seus respectivos diagramas de dispersão de resíduos.

Figura 53: Relações entre o peso total e comprimento total dos exemplares fêmeas (RJ Fem), machos (RJ - Mac) e sexos agrupados (RJ) de T. lepturus da região de Arraial do Cabo (RJ), e seus respectivos diagramas de dispersão de resíduos.

Figura 54: Relações entre o comprimento anal e comprimento total dos exemplares fêmeas (SP -Fem), machos (SP - Mac) e sexos agrupados (SP) de T. lepturus da costa de São Paulo, e seus respectivos diagramas de dispersão de resíduos. 
Figura 55: Relações entre o comprimento total e comprimento anal dos exemplares fêmeas (SP -Fem), machos (SP - Mac) e sexos agrupados (SP) de T. lepturus da costa de São Paulo, e seus respectivos diagramas de dispersão de resíduos.

Figura 56: Relações entre o peso total e comprimento total dos exemplares fêmeas (SP Fem), machos (SP - Mac) e sexos agrupados (SP) de T. lepturus da costa de São Paulo, e seus respectivos diagramas de dispersão de resíduos.

Figura 57: Relações entre o comprimento anal e comprimento total dos exemplares fêmeas ( $\mathrm{SC}-\mathrm{Fem})$, machos ( $\mathrm{SC}-\mathrm{Mac})$ e sexos agrupados $(\mathrm{SC})$ de $T$. lepturus de Porto Belo (SC), e seus respectivos diagramas de dispersão de resíduos.

Figura 58: Relações entre o comprimento total e comprimento anal dos exemplares fêmeas ( $\mathrm{SC}-\mathrm{Fem})$, machos ( $\mathrm{SC}-\mathrm{Mac})$ e sexos agrupados $(\mathrm{SC}) \mathrm{de}$ T. lepturus de Porto Belo (SC), e seus respectivos diagramas de dispersão de resíduos.

Figura 59: Relações entre o peso total e comprimento total dos exemplares fêmeas ( $\mathrm{SC}$ Fem), machos (SC - Mac) e sexos agrupados (SC) de T. lepturus de Porto Belo (SC), e seus respectivos diagramas de dispersão de resíduos.

Figura 60: Freqüência absoluta dos exemplares de T. lepturus, por classe de comprimento anal e sexo, capturados nos diversos Estados.

Figura 61: Boxplot do peso das gônadas por sexo e estádio de maturidade dos exemplares de T. lepturus capturados em cada Estado. A seta indica escala diferenciada dos demais.

Figura 62: Freqüência relativa mensal de estádios de maturidade de fêmeas de $T$. lepturus coletados nos diferentes Estados.

Figura 63: Freqüência relativa mensal de estádios de maturidade de machos de $T$. lepturus coletados nos diferentes Estados.

Figura 64: Variação mensal das relações gonadossomáticas médias (RGS1 e RGS2) e fatores de condição alométrico médios (K e K') de fêmeas e machos de $T$. lepturus coletados em Arraial do Cabo (RJ).

Figura 65: Boxplot dos índices gonadais (IG) mensais das fêmeas de T. lepturus coletadas na região de Arraial do Cabo (RJ).

Figura 66: Variação mensal das relações gonadossomáticas médias (RGS1 e RGS2) e fatores de condição alométrico médios (K e K') de fêmeas e machos de $T$. lepturus coletados no Guarujá (SP), e suas respectivas diferenças em fêmeas.

Figura 67: Boxplot dos índices gonadais (IG) mensais das fêmeas de T. lepturus coletadas em São Paulo.

Figura 68: Variação mensal das relações gonadossomáticas médias (RGS1 e RGS2) e fatores de condição alométrico médios ( $\mathrm{K}$ e $\mathrm{K}$ ') de fêmeas e machos de $T$. lepturus coletados em Porto Belo (SC), e as suas respectivas diferenças em fêmeas.

Figura 69: Boxplot dos índices gonadais (IG) mensais das fêmeas de T. lepturus coletadas na região de Porto Belo (SC).

Figura 70: Curva de freqüência relativa acumulada de fêmeas e machos adultos por classe de comprimento total $(\mathrm{mm})$ de T. lepturus coletados nos diferentes Estados 
Figura 71: Distribuição de freqüência absoluta de diâmetros de ovócitos das gônadas de fêmeas maduras $(\mathrm{C}$ e $\mathrm{C} / \mathrm{H})$ de $T$. lepturus, coletados em diferentes amostras de São Paulo e Santa Catarina.

Figura 72: Relações entre fecundidade (em número de ovócitos) e comprimento total (Lt $-\mathrm{mm}$ ) e peso total $(\mathrm{Wt}-\mathrm{g})$ das fêmeas maduras de T. lepturus coletados em São Paulo e Santa Catarina.

Figura 73: Otólito sagitta de T. lepturus: fêmea com $1230 \mathrm{~mm}$ de comprimento total. Comprimento do otólito $7,8 \mathrm{~mm}$.

Figura 74: Cortes transversais de otólitos de T. lepturus com indicação dos anéis de crescimento

Figura 75: Boxplot dos raios de cada anel observado nos otólitos de T. lepturus coletados nos diferentes Estados analisados.

Figura 76: Constância na formação dos anéis dos otólitos de indivíduos de diferentes idades de T. lepturus em cada Estado analisado.

Figura 77: Proporção bimestral de borda opaca (O) e translúcida (T) nos otólitos dos exemplares de T. lepturus coletados em cada Estado.

Figura 78: Variação bimestral do incremento marginal médio (IM) para exemplares de $T$. lepturus com 2, 4 e 5 anéis de crescimento nos otólitos.

Figura 79: Curvas ajustadas pelo modelo logístico $\left(\mathrm{Lt}=\mathrm{a} / 1+\mathrm{b} * \mathrm{c}^{\mathrm{Rt}}\right)$ aos dados de comprimento total $(\mathrm{Lt})$ e raio total dos otólitos $(\mathrm{Rt})$ de $T$. lepturus da região de Arraial do Cabo (RJ) e respectivos diagramas de dispersão de resíduos.

Figura 80: Curvas ajustadas pelo modelo logístico $\left(\mathrm{Lt}=\mathrm{a} / 1+\mathrm{b} * \mathrm{c}^{\mathrm{Rt}}\right)$ aos dados de comprimento total $(\mathrm{Lt})$ e raio total dos otólitos $(\mathrm{Rt})$ por sexo de T. lepturus da costa de São Paulo e respectivos diagramas de dispersão de resíduos.

Figura 81: Curvas ajustadas pelo modelo logístico $\left(\mathrm{Lt}=\mathrm{a} / 1+\mathrm{b} * \mathrm{c}^{\mathrm{Rt}}\right)$ aos dados de comprimento total $(\mathrm{Lt})$ e raio total dos otólitos $(\mathrm{Rt})$ por sexo de T. lepturus da região de Porto Belo (SC) e respectivos diagramas de dispersão de resíduos.

Figura 82: Curvas do modelo de crescimento de von Bertalanffy ajustadas aos dados do conjunto OtolTot de T. lepturus da região de Arraial do Cabo (RJ), por sexo e agrupados.

Figura 83: Curvas do modelo de crescimento de von Bertalanffy ajustadas aos dados do conjunto OtolTot de T. lepturus da costa de São Paulo, por sexo e agrupados.

Figura 84: Curvas do modelo de crescimento de von Bertalanffy ajustadas aos dados do conjunto OtolTot de T. lepturus da região de Porto Belo (SC), por sexo e agrupados.

Figura 85: Curvas de Captura de comprimentos convertidos em idade de T. lepturus em cada Estado analisado. Os pontos em negrito foram utilizados na regressão linear.

Figura 86: Rendimento relativo por recruta (Y'/R) em função das taxas de explotação (E) e mortalidade por pesca $(F)$; e biomassa relativa por recruta $\left(B^{\prime} / R\right)$ em função da taxa de mortalidade por pesca $(\mathrm{F})$ de $T$. lepturus da região de Arraial do Cabo (RJ), com indicação dos pontos de referência $E_{\max }, E_{0.1}, F_{\max }$ e $F_{0.1}$.

Figura 87: Rendimento relativo por recruta ( $\left.\mathrm{Y}^{\prime} / \mathrm{R}\right)$ em função das taxas de explotação (E) e mortalidade por pesca (F); e biomassa relativa por recruta (B'/R) em função da taxa de mortalidade por pesca $(\mathrm{F})$ de $T$. lepturus da costa de São Paulo, com indicação dos pontos de referência $\mathrm{E}_{\max }, \mathrm{E}_{0.1}, \mathrm{~F}_{\max }$ e $\mathrm{F}_{0.1}$.

Figura 88: Rendimento relativo por recruta (Y'/R) em função das taxas de explotação (E) e mortalidade por pesca $(F)$; e biomassa relativa por recruta $\left(B^{\prime} / R\right)$ em função da taxa de mortalidade por pesca $(\mathrm{F})$ de T. lepturus da região de Porto Belo (SC), com indicação dos pontos de referência $\mathrm{E}_{\max }, \mathrm{E}_{0.1}, \mathrm{~F}_{\max }$ e $\mathrm{F}_{0.1}$. 


\section{AGRADECIMENTOS}

Ao Prof. Dr. Miguel Petrere Junior, meu orientador, pelo apoio, carinho e muita compreensão.

Ao Prof. Dr. Alexandre Wagner Silva Hilsdorf, meu co-orientador, pela confiança e incentivo.

Ao CNPq, Conselho Nacional de Desenvolvimento Científico e Tecnológico, pela bolsa de doutorado.

À FAPESP, Fundação de Amparo à Pesquisa do Estado de São Paulo, pelo financiamento do projeto temático no. 01/13299-7.

Ao IOUSP, Instituto Oceanográfico da Universidade de São Paulo, pelo espaço fornecido.

À UNIVALI, Universidade do Vale do Itajaí (SC), à Associação dos Pescadores Artesanais de São Pedro da Aldeia (RJ), e ao Instituto de Pesca de Santos, pelos laboratórios e todo apoio técnico e logístico.

Aos amigos Prof. Dr. Manuel Haimovici (RS), Profa. Dra. Rosangela Lessa (PE), Profa. Dra. Patrícia Cunningham (SP), Profa. Dra. Rosália Cutri de Souza (PA) e MSc. Roberta Gonçalves Ikeda (PA) pelas amostras de espada para análises de estrutura genético-populacional.

À Empresa Pioneira da Costa S/A, pelo fornecimento do material de Santa Catarina.

À Empresa Itafish, na pessoa do Sr. Lutz, pelo material de São Paulo.

\section{E a uma multidão de gente me ajudou a chegar até aqui...}

Meus irmãos da labuta de campo... querida Aline e o super maridão Chico, e Zé Maria, amigaço.... meus braços Norte e Sul...

Minha irmã ... Dra. Adriana Saad... você é incrível... e o super pescador Chico (e a linda Milena)... beijos...

Meu anjo da guarda... fêmea e oriental... Meire Kikuchi, que bom, você apareceu de novo...

Meus queridos e sinceros amigos Márcio, Michael, Ritinha linda, Izair, e a super Suzuki... sempre prontos, a qualquer hora, sempre doando sua luz...

Ao amigo de todas as horas e distâncias... Luiz Miguel Casarini... você é o cara....

Meus pais adotivos... Dona Esmeralda e Seu Chico, no Rio; Rozeli e Kotas e o maninho Daniel (sem esquecer da Pituca), Dona Mércia e Seu Oswaldo e meu querido 
Marcelo Ribeiro, grande cara..., em Santa Catarina; Cláudia e Gastão, Cíntia e Antonio Olinto em Santos; Super Cláudia Mucinhato e Acácio.... não há como negar... vocês me mimaram muito...

Aos que me empurraram para o doutorado... Paula Gênova e Zavala... valeu o estímulo...

Meus amigos do peito... Mestre Pedro, super força, e Mestre Kiko... valeu pelo apoio e pelos peixinhos...

Meu amigo de bordo em Porto Belo... Branco... super gente boa...

Meus novos amigos... Sr. Choshiro e Irineia... pelo apoio no japonês... muito obrigada... Meus amigos da UNIVALI... Pezzuto e Eliana, Angel, Humber, Schwingel... por me abrirem as portas dos laboratórios e do coração... e a turma da Kombi, Flávio, Nívea, Rodrigo, Eurides, Joãozinho... obrigada...

O grande Paulo Azevedo, da FIPAC... Sr. Competência...

Minha amigona Dra. Mayra Martins, da ESALQ, salvadora da pátria... e Welington... pela força e carinho... (vou levar o peixe...)...

Aos hoje Professores, mas sempre amigos Mary, June, Michel... minha admiração...

À dupla IBAMA... Suzy Saccardo e Cris Cergole... meu carinho...

À moçada do apoio moral ... suuuuper Ricardo Menga, Andressa, Cínthia, Robertinha (Piracicaba), Profa. Yara Novelli, Nilamon, Mônica, Daniela, Amanda, Kika, Gabi, Marinella, André, Roberto, Didi e Betão da lanchonete... não esqueço de vocês... (mas sei que esqueci de um monte...)

À turma do NIB de Mogi das Cruzes... galerinha fera... super Ângela, Thaty, Juliana, Sara, Fábio, André, Cris e Dimona... beijinhos carinhosos... (esqueci de alguém... com certeza...é a idade...)

As queridas da secretaria Silvana e Aninha... altas reclamações... sentirei saudade...

Ao pessoal da biblioteca... Rai, Maria, Cida, Cláudia, Domingos... xiiiiiii... todo mundo que correu atrás de mim pelos livros atrasados... meu grande abraço...

Aos meus filhos... caninos e felinos... pelos momentos de prazer...

A todos os funcionários e amigos do IOUSP... anos de amizade...

À minha mãe Maria... luz e amor que sustentam minha vida... meu muito obrigada....

Ao meu companheiro e amigo... Ricardo Diniz... eu não chegaria tão longe sem você...

Enfim... A todos que (sei que esqueci de muitos) estiveram de alguma forma presentes nos degraus desta escada que subi... OBRIGADA... 


\section{RESUMO}

Os aspectos da pesca do espada, Trichiurus lepturus (Linnaeus, 1758) (Trichiuridae), foram descritos e analisados para as artes de pesca artesanal de linha-demão em Arraial do Cabo (RJ) e cerco flutuante em Porto Belo (SC), e da pesca comercial de arrasto de fundo com parelhas na costa de São Paulo. Verificaram-se tendências crescentes na produção da espécie, principalmente na pesca artesanal. Foram utilizados marcadores moleculares tipo RAPD para analisar a estrutura genéticopopulacional da espécie com exemplares de Belém (PA), Natal (RN), Arraial do Cabo (RJ), Guarujá (SP), Porto Belo (SC) e Rio Grande (RS), evidenciando-se uma população distinta em Belém, enquanto as demais não apresentaram estruturação definida. A dinâmica de populações foi analisada para exemplares de Arraial do Cabo, São Paulo e Porto Belo, coletados mensalmente de janeiro/2002 a julho/2003. A desova da espécie é parcelada com período reprodutivo ocorrendo do verão ao início do inverno. As fêmeas maduras migram para a plataforma encontrando-se com os machos maduros que ali permanecem, retornando à costa após a desova. $\mathrm{O}$ comprimento médio de primeira maturação sexual variou de 647 a $670 \mathrm{~mm}$ (Lt) para fêmeas, e de 526 a $650 \mathrm{~mm}$ para machos. As estimativas dos parâmetros de crescimento foram as seguintes: para fêmeas $\mathrm{L}_{\mathrm{oo}}$ de 1740 a $2010 \mathrm{~mm}$; $\mathrm{k}$ de 0,12 a $0,15 /$ ano e $\mathrm{t}_{0}$ de $-1,642$ a -2,517 anos; para machos $\mathrm{L}_{\mathrm{oo}}$ de 1373 a $1580 \mathrm{~mm}$; $\mathrm{k}$ de 0,17 a $0.25 /$ ano e $\mathrm{t}_{0}$ de $-1,662$ a $-1,866$ anos. A longevidade foi cerca de 14 anos. As taxas de mortalidade natural variaram de $0,20 \mathrm{a}$ 0,29/ano. O modelo de rendimento relativo por recruta indicou que as taxas de mortalidade por pesca do espada estão próximas ou já ultrapassam os limites do rendimento máximo sustentável.

Palavras chave: Trichiurus lepturus, espada, Sudeste-Sul do Brasil, estrutura populacional, marcadores RAPD, reprodução, crescimento, mortalidades. 


\section{ABSTRACT}

The fishery aspects of the cutlassfish, Trichiurus lepturus (Linnaeus, 1758) (Trichiuridae), were analyzed for the artisanal fishery of line and hook of Arraial do Cabo (RJ) and floating encirclement of Porto Belo (SC), and of the commercial paired bottom trawlers in the coast of São Paulo. Tendencies in increasing yields were detected, mainly in the artisanal fishery. RAPD markers techniques were employed in order to analyze the genetic-population structure of the cutlassfish from Belém (PA), Natal (RN), Arraial do Cabo (RJ), Guarujá (SP), Porto Belo (SC) and Rio Grande (RS), showing a different population in Belém, while the others did not show a clearly defined structure. The population dynamics were analyzed for fishes of Arraial do Cabo, São Paulo and Porto Belo, collected monthly of January/2002 to July/2003. The cutlassfish spawning is parceled with reproductive period from the summer to the beginning of the winter. Ripe females migrate offshore to mate with ripe males that stay there, returning to the coast just after spawning. The length of first sexual maturity varied from 647 to $670 \mathrm{~mm}(\mathrm{Lt})$ for females, and 526 to $650 \mathrm{~mm}$ for males. The estimates of growth parameters were: for females $\mathrm{L}_{\mathrm{oo}}$ from 1740 to $2010 \mathrm{~mm}$; $\mathrm{k}$ from 0,12 to $0,15 /$ year and $\mathrm{t}_{0}$ from $-1,642$ to $-2,517$ years, and for males $\mathrm{L}_{\mathrm{oo}}$ from 1373 to $1580 \mathrm{~mm}$; $\mathrm{k}$ from 0,171 $0.255 /$ year and $t_{0}$ from $-1,662$ to $-1,866$ years. The longevity was about 14 years. The natural mortality rate varied from 0,20 to 0,29 /year. The relative yield per recruit model showed that fishing mortality rates of the cutlassfish are close or just exceeding the limits of the maximum sustainable yield.

Key words: Trichiurus lepturus, cutlassfish, Southeast-south of Brazil, RAPD markers, genetic-population structure, reproduction, growth, mortalities. 


\section{INTRODUÇÃO}

A importância dos recursos vivos do mar advém não apenas de sua explotação com a finalidade de produção de alimentos, sob enfoque de recursos pesqueiros, mas também de sua biodiversidade, enquanto patrimônio genético, e como fonte potencial para utilização na biotecnologia (V PSRM, 1999).

Em 2004, a produção de pescado nacional atingiu mais de 1 milhão de toneladas, sendo a metade proveniente da pesca extrativa marinha. A região sudeste-sul foi responsável por 260.000 t, sendo $81 \%$ provenientes da pesca industrial e $19 \%$, da artesanal (IBAMA, 2005).

Os peixes pelágicos, organismos que se aproveitam da coluna d'água como local de desenvolvimento de seus ciclos de vida (reprodução, crescimento, alimentação) são responsáveis por mais de $45 \%$ da produção global de peixes. São suscetíveis às artes de pesca, principalmente à pesca com redes de cerco, onde grandes grupos de peixes são capturados devido a sua organização em cardumes, como característica de comportamento social (Bailey, 1992 apud Pitcher, 1995). Esses peixes planctófagos requerem como essencial para sua sobrevivência no nicho espacial pelágico, o acesso a altas taxas de produção planctônica, as quais formam manchas ("patches") de alimentos. Este fato leva à alta produção de peixes, sendo comum se obter resultados da ordem de $8 \mathrm{t} / \mathrm{km}^{2} /$ ano para peixes pelágicos, enquanto que para peixes demersais observa-se menos da metade desse valor (Pitcher, 1995).

Os recursos pesqueiros da coluna d'água associados ao fundo marinho são denominados demersais. Nas regiões de plataforma continental tais recursos são bastante abundantes, em fundos de areia e/ou lama, constituindo parcela importante no ecossistema marinho. De acordo com Yáñez-Arancibia \& Sanchez-Gill (1988), os recursos demersais são ligados ao fundo marinho em função de seus hábitos reprodutivo, alimentar ou migratório. Nas costas tropicais e subtropicais são recursos pesqueiros dos mais importantes, sendo suas características de diversidade, abundância e distribuição dependentes das condições ecológicas do ecossistema e de interações bióticas. A pesca de espécies demersais na região Sudeste/Sul do Brasil é praticada por meio de diversas artes de pesca, tais como arrasteiros de parelha e portas, simples e tangones, linha-de-mão, espinhel de fundo, rede de emalhe e covos, sendo principalmente as parelhas direcionadas à captura de peixes demersais costeiros (Valentini et al., 1991; IBAMA, 1993; Haimovici, 1997; Perez et al., 2001). 
Entre os principais estoques de peixes pelágicos da costa sudeste/sul brasileira, a sardinha-brasileira (Sardinella brasiliensis) destaca-se como principal recurso pesqueiro, responsável por mais de $30 \%$ da produção nacional de pescado (Dias-Neto \& Dornelles, 1996). Já a captura de peixes demersais na região sudeste é dirigida a três espécies principais pescadas simultaneamente: corvina (Micropogonias furnieri), pescada-foguete (Macrodon ancylodon) e goete (Cynoscion jamaicensis) (Castro, 1998; Castro, 2000).

A contínua explotação desses recursos vem provocando sérias oscilações em suas produções. Tanto os recursos pelágicos, como a sardinha-verdadeira, como as principais espécies demersais, vêm sofrendo queda de produção, o que reflete um problema biológico, onde os estoques já não conseguem manter uma taxa de produtividade capaz de gerar uma oferta de produtos pesqueiros a preços competitivos (Cergole \& Valentini, 1994; IBAMA, 1995; Castro, 1998).

Segundo Hilborn \& Walters (1992), no caso de pescarias multiespecíficas, com a queda de produtividade das espécies de maior interesse, a pesca progressivamente será desviada para outras espécies menos valiosas. Em ambas pescarias, pelágicos e demersais, várias outras espécies são também capturadas e vêm assumindo importância crescente nos desembarques. Dentre elas, podemos destacar o espada Trichiurus lepturus, segunda espécie de teleósteo mais abundante nos cruzeiros oceanográficos do Programa REVIZEE (Figueiredo et al., 2002) e quarta espécie nos levantamentos da plataforma sul do Brasil, capturado principalmente na pesca com redes de arrasto (Haimovici, 1997).

Apesar de evidências de um forte potencial de captura do espada na região Sudeste-Sul do Brasil, não há uma pescaria direcionada para a explotação dessa espécie (com. pess. Hélio Valentini, Dr. - Instituto de Pesca, Santos, SP). Entretanto, têm sido registradas capturas crescentes de espada nas pescarias da região sudeste-sul do Brasil. Informações da Fundação Instituto de Pesca de Arraial do Cabo (FIPAC-RJ) apontam que, durante o primeiro semestre de 2001, o espada representou mais de $30 \%$ do total capturado na região.

Trichiurus lepturus Linnaeus, 1758 (Figura 01), conhecida como Espada, pertencente à família Trichiuridae (Teleostei), é espécie cosmopolita, que se distribui da zona costeira até $120 \mathrm{~m}$ de profundidade. Sua ocorrência é mais freqüente na Primavera, Verão e Outono, apresentando maior abundância à salinidades de 33 a 35,5 e 
temperaturas maiores de $15^{\circ} \mathrm{C}$. Águas à temperaturas inferiores a $11^{\circ} \mathrm{C}$ são consideradas barreiras oceanográficas para sua distribuição, relacionando-se à tolerância fisiológica da espécie (Bellini, 1980; Nakatami et al., 1980; Baik \& Park, 1986; FUNDESPA, 1994; Haimovici et al., 1994; Martins \& Haimovici, 1997).

Apresenta hábito demerso-pelágico, formando cardumes migrantes a partir de $50 \mathrm{~cm}$ de comprimento (Narasimham, 1976; Haimovici et al., 1994). É espécie oportunista, altamente voraz, e realiza migração vertical, deslocando-se para o fundo durante o dia para alimentação. A sua ocorrência está relacionada com a presença de cardumes de pequenos pelágicos, dos quais se alimenta (Bellini, 1980; Matsuoka et al., 1993; Graça-Lopes et al., 1993; Haimovici et al., 1994; Pucci, 2004; Muto et al., 2005; Martins et al., 2005).

Sua produção está entre as 10 espécies mais pescadas do mundo, principalmente em águas orientais (Bartley, 2005), sendo as maiores capturas com redes de arrasto obtidas durante o dia (Bellini, op. cit.; Matsuoka et al., op. cit.; Haimovici et al., 1994; Haimovici et al., 1996; Kwok \& Ni, 1999).

Estudos sobre sua reprodução indicam que T. lepturus apresenta desova prolongada, da primavera ao outono, principalmente no verão, sendo encontrados ovos e larvas principalmente no outono (Munekiyo \& Kuwahara, 1984; Sheridan et al., 1984; Haimovici et al., 1994, 1996; Martins \& Haimovici, 1997; Kwok \& Ni, 1999; Martins \& Haimovici, 2000).

Em estudos desenvolvidos por todo o mundo, a idade máxima observada para a espécie foi de 6 anos, verificando-se crescimento diferenciado entre coortes de épocas distintas (Bellini, op. cit.; Munekiyo \& Kuwahara, 1988; Kwok \& Ni, 2000).

Magro et al. (2000) elaboraram uma resenha bibliográfica das vinte espécies potencialmente explotáveis na região Sudeste e Sul do Brasil, para ser utilizada como subsídio de futuros estudos sobre o manejo e conservação, dentre elas Trichiurus lepturus.

Até o momento, inexistem estudos completos de biologia pesqueira e pesca exploratória do espada na região sudeste/sul. Estudos preliminares foram desenvolvidos por Bellini (1980), com exemplares capturados em cruzeiros oceanográficos sazonais realizados no Programa FAUNEC, desenvolvido em 1975 pelo Instituto Oceanográfico da USP, e mais recentemente os estudos sobre bioecologia da espécie, desenvolvido por Martins (1992), obtido em cruzeiros oceanográficos na plataforma continental do Rio Grande do Sul, realizados pela Fundação Universidade do Rio Grande (FURG). 
No Programa “Avaliação do Potencial Sustentável de Recursos Vivos na Zona Econômica Exclusiva" - REVIZEE, coordenado pelo MMA, a espécie Trichiurus lepturus foi considerada importante recurso pesqueiro potencial no Score-Sul, por apresentar capturas superiores a 1.000 t no período de 1986 a 1995, e foram desenvolvidos estudos preliminares da dinâmica populacional da espécie, com dados obtidos em 1997-98, não conclusivos, mas que serão utilizados para subsidiar o presente estudo (Magro \& Cergole, 2000).

A necessidade de explotar os recursos pesqueiros tropicais e subtropicais impõe um desafio de se conhecer cientificamente essas comunidades de alta complexidade e diversidade, antes que o avanço tecnológico imponha uma sobrexplotação aos recursos, na maioria das vezes, pouco conhecidos (Castro, 2000).

Nesse sentido, Cushing (1975) chamou a atenção quanto à necessidade de integrar estudos de ecologia marinha e biologia pesqueira, tanto na formação curricular quanto na prática investigativa. De acordo com Caddy \& Sharp (1986), é importante lembrar a relevância que a ecologia marinha tem para as pescarias, pois "se se pretende minimizar os efeitos adversos da pesca e não comprometer a capacidade do sistema em sustentar uma atividade humana produtiva, deve-se ter consciência de que os componentes explotados de um sistema complexo estão ligados a outros, que não são explotados, mas que podem ser essenciais à produtividade econômica do sistema”.

Assim, estudos sobre aspectos biológicos e pesqueiros são extremamente relevantes para o conhecimento das espécies de interesse, uma vez que tais pesquisas terão importância para a conservação e manejo do recurso, prolongando seu aproveitamento.

A explotação racional de um recurso pesqueiro requer, em primeiro lugar, delimitar as chamadas unidades de população ou estoques. Define-se como estoque "um grupo intraespecifico de organismos, cujo fluxo gênico ocorre aleatoriamente com integridade espacial e temporal"' (Ihssen et al., 1981).

Uma espécie com distribuição geográfica ampla pode estar constituída por várias populações ou estoques, ou por diferentes subespécies, que devem ser claramente identificados, já que as mudanças em um deles, tanto naturais como as provocadas pela atividade pesqueira, não afetam os demais. Para tanto, definir a identidade dos estoques tem grande importância para o manejo da pesca. A longo prazo, o manejo deve ter como 
ponto de partida a diversidade genética intra e inter populacional, sendo o conhecimento da estrutura genético-populacional da espécie um parâmetro importante para que os estoques (ou populações) presentes em uma mesma área (apresentando diferenças genéticas), possam ser tratados como unidades diferentes em que a captura e esforços de pesca devam ser diferenciados (Beddington et al., 1990).

As barreiras que impedem a troca de genes entre indivíduos de uma mesma espécie geralmente não são intensas em ambientes marinhos. A escolha da ferramenta a ser utilizada para avaliar o grau de diferenciação é um importante passo para obtenção de resultados significativos, pois servem para avaliar a estrutura populacional em espécies aquáticas.

Estudos populacionais que descrevam as propriedades dinâmicas de uma população, tais como abundância, rendimento, idade, crescimento, recrutamento, mortalidade, dentre outros, são pertinentes somente a estoques simpátricos, sendo sensíveis a fatores extrínsecos (ambientais). Tais estudos caracterizam mais o ambiente ocupado, e assim, diferenças significativas entre grupos podem ser aceitas como evidências de diferentes ambientes. Fatores ambientais podem modificar a expressão de genes responsáveis por caracteres merísticos, muitas vezes alvo de estudos para distinguir populações. Assim, a expressão fenotípica desses caracteres representa uma complexa reciprocidade entre fatores genéticos, fisiológicos e ambientais. Já estudos desenvolvidos com estruturas calcificadas, principalmente otólitos, são ótimos identificadores de estoques quanto ao formato, posição e forma do núcleo, tamanho dos anéis, etc. (Ihssen et al., 1981).

Porém, foi o uso de fenótipos eletroforéticos de proteínas (STOCS, 1981) e a grande variabilidade encontrada nos ácidos nucléicos (Ferris \& Berg, 1987) que permitiram avanços significativos no estudo da estrutura populacional de vários grupos de animais. O desenvolvimento de técnicas de biologia molecular permitiu o descobrimento de grande número de marcadores moleculares no DNA, que abriu as fronteiras dos estudos evolutivos e populacionais em diversas espécies. Silva \& Russo (2000) apresentaram um levantamento bibliográfico sobre técnicas e análises estatísticas utilizadas nos estudos de genética de populações. Os autores evidenciaram que a maioria desses estudos (76\%) utilizou as técnicas de RFLP (Restriction Fragment Lenght Polymorphism) (44\%), sequenciamento (18\%) e RAPD (Randomly Amplified Polimorphic DNA) (14\%). 
Marcadores de RAPD (Williams et al., 1990) têm sido utilizados como ferramenta em diversos estudos de mapeamento genético, genético-populacionais, evolutivos e taxonomia. Essa técnica consiste na amplificação do DNA nuclear sem prévio conhecimento da seqüência do DNA. O RAPD tem como princípio a amplificação do DNA através de "primers" (seqüências de DNA) aleatórios que identificam em mínimas quantidades de DNA marcadores que se expressam por herança mendeliana (dominante ou recessivo). A maior simplicidade para identificação de marcadores de DNA quando comparado às outras técnicas, tem feito com que o RAPD venha sendo usado com relativa freqüência em estudos genético-populacionais (Bielawski \& Pumo, 1997; Clark \& Lanigan, 1993).

Devido sua ampla distribuição geográfica e sua importância como recurso pesqueiro potencial na região do Sudeste/Sul do Brasil, acredita-se de fundamental importância o estudo da dinâmica de população da espécie Trichiurus lepturus em conjunto com avaliações de sua estrutura populacional para o futuro manejo da pesca e sua conservação. 


\section{CARACTERIZAÇÃo DA ÁREA DE ESTUDO}

Em função dos diferentes ambientes físicos, Castro \& Miranda (1998) dividem a costa Sudeste-Sul do Brasil em duas zonas, sendo: Embaiamento do Sul do Brasil $\left(23^{\circ} \mathrm{S}-28,5^{\circ} \mathrm{S}\right)$ e Plataforma Sul Brasileira $\left(28,5^{\circ} \mathrm{S}-34^{\circ} \mathrm{S}\right)$. O presente estudo abrangerá principalmente o Embaiamento do Sul do Brasil. Segundo esses autores, o embaiamento se encontra entre dois cabos proeminentes, Cabo Frio (RJ) e Cabo de Santa Marta Grande (SC) abrangendo linha de costa de aproximadamente $1.100 \mathrm{~km}$.

A característica oceanográfica da região é a presença sazonal da Água Central do Atlântico Sul (ACAS) sobre o domínio interior da plataforma continental (10 a $50 \mathrm{~m}$ de profundidade). Durante o verão, a ACAS, que ocupa a camada abaixo da Corrente do Brasil ao longo do talude continental, penetra na camada de fundo sobre a plataforma, alcançando a região costeira. Durante o Inverno, a ACAS se retrai em direção à margem da plataforma continental. Devido à penetração dessa massa de água fria e ao aquecimento da água superficial, forma-se uma termoclina marcante durante o verão, numa profundidade de aproximadamente 10 a 15 m (Matsuura, 1995).

Brandini et al. (1997) também ressaltam a importância de alguns processos oceanográficos de grande escala que afetam favoravelmente a estrutura e dinâmica do ecossistema da plataforma Sudeste-Sul:

* Intrusão da ACAS no assoalho da plataforma durante o verão, acentuando a termoclina;

* Proximidade da Zona de Convergência das Correntes Brasil/Malvinas;

* Ressurgência de borda de plataforma causadas por vórtices frontais ciclônicos da Corrente do Brasil;

* Ressurgência de Cabo Frio, RJ;

* Drenagem continental da Lagoa dos Patos e do Rio da Prata, que invadem setores ao norte da plataforma entre o Rio Grande do Sul e Santa Catarina.

Tais fatores têm influência direta nos aumentos de produção primária no verão, que juntamente com a estabilidade na coluna d'água favorecem a sobrevivência de larvas planctônicas de animais marinhos, de modo que a grande maioria dos peixes e megabentos têm sua época de reprodução concentrada nessa época do ano. A estrutura e função do ecossistema da Área Sudeste foram largamente estudadas em investigação multidisciplinar desenvolvida na região costeira de Ubatuba (Pires-Vanin \& Matsuura, 1993). 


\section{OBJETIVOS}

Este trabalho tem por objetivos descrever e avaliar aspectos de diferentes artes de pesca que exploram a espécie Trichiurus lepturus na região sudeste-sul do Brasil, bem como analisar sua dinâmica de populações enfocando a estrutura genéticopopulacional, reprodução, crescimento e mortalidade, no intuito de se obter as informações necessárias para o manejo e conservação da espécie. 


\section{METODOLOGIA}

A espécie Trichiurus lepturus, segundo o relatório de estatística pesqueira do IBAMA (2004), passa a constar nas listas de peixes explotados somente a partir do Estado da Bahia, com considerável captura na pesca artesanal. Na região sudeste-sul, é capturada em praticamente todas as artes de pesca, principalmente na pesca artesanal do Rio de Janeiro e Santa Catarina. Em São Paulo, apresenta maior participação na pesca comercial. Já no Rio Grande do Sul, a espécie não consta nas estatísticas da região.

Assim, foram verificados pontos de atuação da pesca artesanal nos Estados do Rio de Janeiro e Santa Catarina, e da pesca comercial de São Paulo, onde a espécie Trichiurus lepturus vem sendo amplamente explorada.

No Rio de Janeiro, optou-se pela pesca em Arraial do Cabo, onde a população local captura o espada na arte de pesca de linha de mão, para consumo local ou no recente mercado surgido nos Estados do Rio de Janeiro e Minas Gerais. Em São Paulo, a espécie é muito capturada na pesca de arrasto de fundo de parelhas, sendo atualmente incluída como categoria de pescado, quando a menos de uma década fazia parte da categoria mistura. Em Santa Catarina, nas cidades de Porto Belo e Florianópolis, vem sendo explotada na arte de cerco flutuante, cujo produto atende ao mercado interno do Sudeste, além de ser exportado aos EUA e Japão.

Dessa forma, obtiveram-se amostras de diferentes artes de pesca em cada Estado (Figura 02), a saber:

- Rio de Janeiro: pesca artesanal de linha de mão

- São Paulo: pesca comercial de arrasto com parelhas

- Santa Catarina: pesca artesanal de cerco flutuante

\section{Obtenção de dados estatísticos das pescarias}

Foram adotadas várias estratégias para a obtenção de dados estatísticos das pescarias alvo deste estudo.

No Rio de Janeiro, devido a dificuldade de implementação de uma rotina de coleta de informações sobre o desembarque, foi obtida apenas a produção pesqueira total anual da região, junto à Fundação do Instituto de Pesca de Arraial do Cabo (FIPAC), sob responsabilidade do MSc. Paulo José de Azevedo Silva. Os dados 
abrangeram totais anuais de captura (em $\mathrm{kg}$ ) e esforço de pesca (em $\mathrm{h}$ de pesca) do período de 1992 a 2002, englobando as artes de cerco, arrasto de praia, rede de armar, espinhel e linha, desenvolvidas na região de Arraial do Cabo. Foram obtidos no momento dos desembarques pela equipe da FIPAC por meio de entrevistas realizadas no cais da Marina Pública dos Pescadores e as praias dos Anjos, Grande e Prainha, em Arraial do Cabo. A descrição e dinâmica da frota pesqueira e a produção da região foram analisadas por Azevedo (2004). A frota é composta por embarcações de pequeno porte, sendo considerada pelo autor como artesanal.

Em São Paulo, os dados estatístico-pesqueiros aqui utilizados foram disponibilizados pela Unidade Laboratorial de Referência em Controle Estatístico da Produção Pesqueira Marinha do Instituto de Pesca/APTA/SAA/SP, através do Sistema Gerenciador de Banco de Dados ProPesq ${ }^{\circledR}$ (Ávila-da-Silva et al., 1999), abrangendo o período de 1998 a 2004. Nestes, constavam informações sobre os desembarques monitorados pela Instituição, abrangendo as artes de cerco, arrasto de fundo (parelhas e tangones), espinhel (de fundo e superfície), linha-de-mão e emalhe, dentre outras.

Para Santa Catarina, foi disponibilizada a produção diária da pesca artesanal de três cercos flutuantes localizados nas Praias de Estaleiro e Caixa D'aço (Porto Belo SC), de propriedade da Pesqueira Pioneira da Costa S/A, constantes no recém implantado banco de dados de controle contábil da empresa, referentes ao período de maio de 2002 a abril de 2003, excetuando-se parte dos meses de maio e julho e o mês de junho de 2002, período de defeso da tainha na região.

\section{Obtenção de dados em campo}

O material utilizado neste trabalho foi coletado mensalmente, durante 18 meses, abrangendo o período de janeiro de 2002 a julho de 2003. Durante as coletas, foram também observadas as respectivas rotinas de cada arte de pesca em cada local pré-determinado.

Ao longo dos desembarques, mediu-se o comprimento anal (em mm) de 200 exemplares de espada no mínimo, com auxílio de ictiômetro de madeira, para obtenção da distribuição mensal de freqüência de comprimentos da espécie. Optou-se pelo comprimento anal dos exemplares, pois durante os procedimentos da pesca, a ponta de sua cauda é comumente prejudicada, daí subestimando o valor do comprimento total. $\mathrm{O}$ 
comprimento anal equivale à distância da ponta do focinho até o início da abertura anal do exemplar.

A pesca artesanal de linha de mão ocorre diariamente na região de Arraial do Cabo, principalmente na Ponta da Prainha, atuando próximo à costa. Dezenas de embarcações, dentre elas 182 denominadas "boca-aberta", registradas na FIPAC, com um a três pescadores em cada, saem todo final de tarde para a pesca do espada com auxílio de lampiões, que atraem seus cardumes, retornando três ou quatro horas depois (Figura 03). Os exemplares capturados são acondicionados em caixas, pesados (Figura 04) e vendidos à peixaria da Praia dos Anjos, de onde seguem para venda na região, do próprio Estado ou para Minas Gerais. Podem ser também filetados em pequenos galpões, ou a céu aberto (Figura 05), e vendidos para os restaurantes da redondeza.

Cerca de $30 \mathrm{~kg}$ de espada oriundos da pesca de linha-de-mão, foram adquiridos diretamente dos pescadores artesanais da Prainha, em Arraial do Cabo (RJ), logo após seu desembarque noturno, durante a pesagem da captura, no período de fevereiro de 2002 a julho de 2003. No mês de maio de 2003, devido à ausência de exemplares provenientes da pesca de linha no período, a amostra foi obtida da pesca de arrastão realizada na Prainha (Figura 06). No mês de julho de 2003, foram obtidos dados de comprimento anal de 194 exemplares de espada provenientes da pesca de parelhas na costa do Rio de Janeiro, a título de comparação. Cuidados foram tomados para que os exemplares das amostras não estivessem prejudicados, tanto na ponta da cauda, como na região da cabeça, que freqüentemente é dilacerada pelo pescador no momento da pesca de linha-de-mão devido a voracidade dos espadas (Figura 07). As coletas foram realizadas com auxílio da Bel. Aline Ferreira Aguiar Leal, bióloga residente na região. O material era então transferido em caixas de gelo para o laboratório na residência da Dra. Adriana Saad, ou para a residência da Bel. Aline, ou à sede da Associação dos Pescadores Artesanais de São Pedro da Aldeia, onde era triado para obtenção de dados biológicos.

O material de estudo no Estado de São Paulo foi obtido das capturas da pesca comercial de arrasto de fundo de parelhas, realizadas pelos barcos da parelha Cigano do Mar III e Cigano do Mar IV (Figura 08), no período de janeiro de 2002 a junho de 2003, perfazendo 17 desembarques em 2002 (16.750 kg de produção de espada) e 10 desembarques até junho de 2003 (13.000 kg de produção de espada). A área de atuação da embarcação abrangeu a região adjacente às ilhas de Queimadas Grande e Pequena, Iguape/Juréia, até as proximidades da Baía de Santos, em profundidades que variaram 
de 15 a 30m, e cujas espécies-alvo da pescaria foram principalmente a corvina (Micropogonias furnieri), o goete (Cynoscion jamicensis), o linguado (Paralichthys sp.) e o peixe-porco (Balistes capriscus), dentre outras. Durante os desembarques, realizados na empresa "Itafish", no Guarujá (SP) (Figuras 9 e 10), foi medido o comprimento anal dos exemplares de espada. Os exemplares utilizados para obtenção dos dados biológicos foram doados pelos Mestres Amauri (Kiko) e Pedro, e transportados ao laboratório no IOUSP em caixas de isopor com gelo para triagem.

Em Santa Catarina, apenas nos meses de janeiro e fevereiro de 2002, as amostras foram obtidas na Praia da Armação (Florianópolis), logo após os procedimentos de despesca dos dois cercos lá existentes. Verificou-se, porém, que todo o capturado nesses cercos é vendido e transportado para a empresa Pioneira da Costa S.A., em Porto Belo, onde é processado para comercialização. Esta empresa também possui três cercos instalados nas Praias de Caixa d'Aço e Estaleiro, em Porto Belo. Assim sendo, optou-se pela amostragem destes cercos, onde mensalmente foram medidos os cerca de 200 exemplares no ato do desembarque e as amostras para análise foram doadas da Empresa.

O cerco flutuante é constituído de uma rede de 100 braças (cerca de $180 \mathrm{~m}$ ) de malha $5 \mathrm{~cm}$ no corpo da rede e $2 \mathrm{~cm}$ no ensacador, instalado próximo à ponta da praia, a $8 \mathrm{~m}$ de profundidade. Toda a rede é mantida aberta da superfície ao fundo por meio de bóias de PVC e lastros (Figura 11). Uma ponta da rede é fixada junto ao costão e esticada por cerca de $50 \mathrm{~m}$, denominada "caminho", e a partir daí é armada em dois círculos, um com cerca de $5 \mathrm{~m}$ de diâmetro no interior de outro com cerca de $20 \mathrm{~m}$ de diâmetro, formando uma espécie de armadilha na porta de entrada do cerco. O cardume é "encaminhado" pela porção reta à boca da rede em círculo, onde ficam presos (Figura 12).

A despesca é realizada todos os dias pela manhã por sete pescadores a bordo de duas embarcações, uma "chata" grande e uma pequena canoa. No ato da despesca, dois pescadores na pequena canoa são responsáveis pelo fechamento da boca da rede no círculo menor (Figura 13). Em seguida, todos os pescadores puxam a rede de forma a irem diminuindo seu diâmetro, empurrando o pescado para o ensacador, no canto do círculo maior (Figura 14). O pescado é, então, despejado na "chata" (Figura 15) e transportado para a empresa Pioneira da Costa, na Praia do Araçá, onde é processado. Os exemplares de espada são acondicionados inteiros ou sem cabeça em formas metálicas, e congelados, para posteriormente serem exportados (Figs. 16 a 19). 
Devido o defeso da tainha na região, que ocorre de meados de abril a meados de junho, quando os cercos flutuantes são retirados do mar, os dados biológicos e de distribuição de freqüência de comprimento anal no mês de maio de 2002 foram provenientes da pesca de arrasto de fundo com parelhas. Os dados de junho de 2002 e 2003 foram oriundos da pesca comercial de cerco. O mesmo fato não permitiu a obtenção de dados no mês de abril de 2003. As coletas foram realizadas com o auxílio do MSc. José Maria de Souza da Conceição, oceanógrafo residente na região. O material era então transportado em caixas com gelo para triagem nos laboratórios da UNIVALI, em Itajaí (SC).

\section{Obtenção de dados em laboratório}

As amostras mensais de espada transferidas aos laboratórios foram triadas sendo obtidos de cada exemplar os dados:

Merísticos:

- número de espinhos da primeira nadadeira dorsal

- número de raios da segunda nadadeira dorsal

- número de raios da nadadeira peitoral

Morfométricos:

- comprimento total $(\mathrm{Lt})$ - em $\mathrm{mm}$, correspondente à ponta do focinho até a ponta da cauda;

- comprimento anal (La) - em mm, correspondente à ponta do focinho até o início da abertura anal;

- peso total (Wt) e peso eviscerado (We) - em g; com balança digital com precisão de $0,1 \mathrm{~g}$;

- peso das gônadas (Wg) - em g, com precisão de 0,01 g;

Estruturas:

- sexo (S) e estádio de maturidade (EM);

- gônadas, preservadas em formalina 10\%;

- par de otólitos "sagittae".

\section{Genéticos:}

Foram obtidas cerca de 20 amostras trimestrais de tecido muscular (cerca de 1 $\mathrm{cm}^{3}$ ), preservadas em etanol $95 \%$, para extração do DNA total dos exemplares. 
Amostras pontuais coletadas em Belém (PA), Natal (RN) e Rio Grande (RS) foram obtidas para avaliação da diversidade genética intra e inter populacional do espada ao longo da costa brasileira, com a colaboração de professores e funcionários da UFPA, UFRPE e FURG.

\section{Análise de dados}

\subsection{Dados estatístico-pesqueiros}

Utilizando-se os dados da pesca de Arraial do Cabo, foram analisadas as proporções de T. lepturus na captura anual e a variação anual da captura por unidade de esforço (CPUE - kg/h), Obteve-se a CPUE média no período e verificaram-se as diferenças entre as CPUE anuais e esta média, aqui considerados desvios da média do período, para a verificação de possíveis tendências na CPUE da espécie.

Para São Paulo, foram utilizados os dados das capturas anuais e mensais do total capturado em todas as artes e de $T$. lepturus para verificação da proporção da espécie na pesca. As proporções mensais das capturas de espada em relação aos seus respectivos totais anuais foram verificadas para determinação do período do ano de maior ocorrência da mesma. As proporções da captura da espécie por arte de pesca também foram analisadas, verificando-se a importância da espécie nas distintas artes.

Verificou-se a importância relativa da espécie nas artes de pesca de sua maior ocorrência em peso, através do método de análise do grau de direcionamento das pescarias, proposto por Biseau (1998) e descrito em Ávila-da-Silva (2002). Esse método permite categorizar a espécie como alvo da pescaria ou acessória, baseando-se na relação entre a freqüência acumulada de desembarques e as contribuições em peso de $T$. lepturus. Para se determinar a participação relativa da espécie na curva resultante ao nível de $80 \%$, denominado nível explicativo (NE), verifica-se o valor no eixo " $\mathrm{x}$ " correspondente à freqüência acumulada (eixo "y”) de 20\% (100-NE).

Para a pesca de arrasto-de-fundo com parelhas, a mais relevante em termos de captura da espécie, e aqui analisada, os dados de captura (kg), esforço (h) e CPUE (captura por unidade de esforço $-\mathrm{kg} / \mathrm{h}$ ) foram descritos por gráficos de densidade tipo boxplot, onde as linhas horizontais do retângulo indicam valores dos quartis 25, 50 (mediana) e 75\%. A barra de erro denota os valores de 5 a $95 \%$. Os dois símbolos (traço e cruz) acima dos 5\% indicam os valores zero e $1 \%$. Os mesmos, abaixo dos 
95\%, indicam os valores 100 e 99\%. O símbolo "quadrado" no interior do retângulo indica a média dos dados. Foram também analisados os desvios das medianas da CPUE trimestral de espada em relação à sua média no período, verificando-se possíveis padrões na ocorrência da espécie no capturado.

Com os dados da pesca de cerco flutuante de Porto Belo (SC), foram determinadas as proporções mensais da espécie na captura, bem como o esforço mensal aplicado (em dias de pesca). Analisou-se a captura por unidade de esforço (CPUE $\mathrm{kg} / \mathrm{dia}$ ) da espécie e suas variações mensais em relação à média do período (anomalias) para verificação de possíveis padrões de ocorrência da espécie na pescaria.

\subsection{Diversidade genética intra e inter populacional}

Analisou-se a diversidade genética intra e inter populacional das amostras obtidas nas diferentes localidades utilizando-se a técnica de marcadores moleculares tipo RAPD. Tais análises foram desenvolvidas no Laboratório de Genética de Peixes e Aqüicultura pertencente ao Núcleo de Ciências Ambientais da Universidade de Mogi das Cruzes, sob a co-orientação do Dr. Alexandre Wagner Silva Hilsdorf, professor da Universidade de Mogi das Cruzes.

Das amostras trimestrais de tecido muscular preservado em etanol no momento do desembarque, extraiu-se o DNA total. O mecanismo de extração foi estabelecido a partir de modificações no protocolo de Taggart et al. (1992), com o aumento da concentração de proteinase $\mathrm{K}$ de $10 \mu \mathrm{l}$ para $15 \mu \mathrm{l}(20 \mathrm{mg} / \mathrm{ml})$ e diminuição da concentração de EDTA diluído no tampão STE (0,1M NaCL, 0,05M de Tris-HCL e

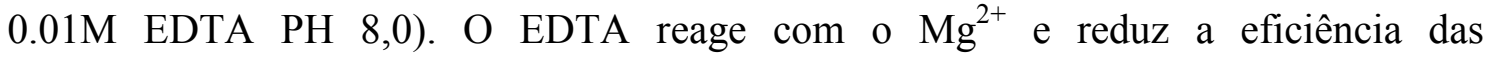
amplificações.

As reações de RAPD foram feitas de acordo com o protocolo estabelecido por Paiva (2001). Demais padronizações das condições de amplificação foram realizadas, variando-se basicamente as concentrações de $\mathrm{MgCl}_{2}$ e a temperatura de anelamento de diversos primers em gradientes de concentração e temperatura.

Após extração, o DNA obtido de 18 amostras de cada local foi amplificado via PCR (Polymerase Chain Reaction), em termociclador PTC-200 (Peltier Thermal Cycler) da MJ Research, com primers aleatórios de 10 nucleotídeos. Grande dificuldade foi 
encontrada no processo de amplificação, pois apesar das extrações apresentarem grande quantidade de DNA, o estado degradado do mesmo não respondia a contento. Mesmo apresentando concentrações equivalentes no espectrofotômetro, cada amostra teve de ser avaliada individualmente em sua diluição para padronização de uma "concentração de resposta”, tentando-se ao máximo aproveitar seu DNA ainda íntegro.

Após inúmeros testes com 32 primers diferentes, utilizando-se amostras em melhores condições de integridade de DNA, optou-se pela utilização daqueles com as seguintes seqüências de nucleotídeos:

\begin{tabular}{|c|c|}
\hline Primer & Seqüência de nucleotídeos \\
\hline Primer 01 & 5'-GAAACACCCC-3' \\
\hline Primer 02 & 5'-CCTGATCACC-3' \\
\hline Primer 03 & 5'-CCAAGCTTCC-3' \\
\hline Primer 04 & 5'-TGGACCGGTG-3' \\
\hline Primer 05 & 5'-AGGCCCGATG-3' \\
\hline
\end{tabular}

As reações de PCR com $25 \mu$ foram montadas em frascos de microcentrífuga com os seguintes reagentes: $2,5 \mu \mathrm{l}$ de Buffer 10X (50 mM), 2,5 $\mu 1$ de Mix dNTP's (2,5mM de cada dNTP), 2,5 $\mu$ de primer $(2 \mu \mathrm{M}), 3,0 \mu 1$ de $\mathrm{MgCl}_{2}(25 \mathrm{mM}), 0,4 \mu 1$ de Taq DNA Polimerase, e 2,5 $\mu$ l de amostra de DNA, complementando o volume final com água deionizada.

A amplificação via PCR seguiu as seguintes condições de amplificação:

\begin{tabular}{|c|c|c|c|}
\hline & Etapas da reação de amplificação & Temperatura & Duração \\
\hline & Denaturação Inicial & $92^{\circ} \mathrm{C}$ & $4 \min$ \\
\hline \multirow{3}{*}{$\underset{\circlearrowright}{\circlearrowright}$} & Denaturação & $92^{\circ} \mathrm{C}$ & $1 \mathrm{~min}$ \\
\hline & Anelamento do primer & $37^{\circ} \mathrm{C}$ & $1: 30 \mathrm{~min}$ \\
\hline & Extensão & $72^{\circ} \mathrm{C}$ & $2 \min$ \\
\hline & Extensão final & $72^{\circ} \mathrm{C}$ & $5 \mathrm{~min}$ \\
\hline & Número de ciclos & 40 & \\
\hline
\end{tabular}


Os produtos da amplificação foram submetidos à eletroforese em gel de agarose a 1,5\%, juntamente com um controle negativo para verificação de possíveis contaminações, e posteriormente imerso em solução de brometo de etídeo $(1 \mathrm{mg} / \mathrm{ml})$ por 15 a 20 min, sendo fotografado em transiluminador da Alpha Innotech Corporation com luz UV em seguida.

As amplificações foram repetidas várias vezes para confirmação do padrão de bandas que apresentaram. Somente os fragmentos amplificados bem demarcados (bandas) e reproduzidos em uma série de amplificações foram considerados. Os resultados de cada primer foram analisados e montaram-se matrizes de presença/ausência $(0,1)$ de bandas.

Para análise da estruturação de populações nos diferentes locais amostrados, a saber: Belém, PA; Natal, RN; Rio de Janeiro (RJ); São Paulo (SP); Porto Belo (SC); e Rio Grande (RS), as matrizes obtidas foram inseridas no programa ARLEQUIN (versão 2.0; Schneider et al., 2000) para análise molecular de variância (AMOVA). Nessa análise, a variância das freqüências gênicas é subdividida em vários componentes hierarquicamente inclusivos, como a variação entre regiões, a variância entre populações $(\Phi s t)$ ou a variância residual entre indivíduos. Obteve-se também a matriz de $\Phi$ st para as regiões pareadas. Valores não significativos de st indicam que a hipótese nula de panmixia não pode ser rejeitada, mas apontam a necessidade de estudos adicionais para verificação da homogeneidade. Para as estimativas de $\Phi$ st significativamente diferentes de zero, os valores superiores a 0,05 indicam alta estruturação populacional (Solé-Cava, 2004).

Para avaliar a similaridade entre as amostras das diversas regiões utilizou-se o coeficiente de similaridade de Jaccard (1901) $((\mathrm{a} / \mathrm{a}+\mathrm{b}+\mathrm{c})$, sendo que $\underline{\boldsymbol{a}}$ se refere ao número de bandas concordantes e $\underline{\boldsymbol{b}}$ e $\underline{\boldsymbol{c}}$, o número de bandas discordantes) e o algoritmo

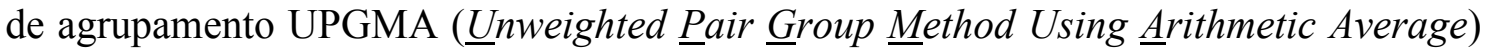
para construção do dendrograma com o total das amostras de T. lepturus de cada região, com o programa NTSYSpc (Rohlf, 1997). A técnica de bootstrap (Efron, 1985) foi utilizada com número de 1000 réplicas para avaliar os limites de confiança do dendrograma, a partir da re-amostragem dos próprios dados com reposição, utilizandose o programa WinBoot (Yap \& Nelson, 1996). 
A distância genética e identidade genética de Ney (1978) foram estimadas para as diferentes regiões, combinadas duas a duas, com o auxílio do programa TFPGA 1.3 (Miller, 1997). As freqüências alélicas foram estimadas baseadas na correção de Lynch \& Milligan (1994). O dendrograma das distâncias genéticas foi obtido pelo método UPGMA, com avaliação por bootstrap baseado em 1000 réplicas.

\subsection{Dados merísticos}

O número de espinhos da primeira nadadeira dorsal, número de raios da segunda nadadeira dorsal e número de raios da nadadeira peitoral dos exemplares de $T$. lepturus foram comparados entre sexos e entre os diferentes Estados analisados.

Verificou-se a normalidade dos dados através do cálculo de simetria $\left(\mathrm{g}_{1}\right)$ e curtose $\left(g_{2}\right)$, e respectivos desvios estandartizados $\left(\operatorname{stg}_{1}\right.$ e $\left.\operatorname{stg}_{2}\right)$, sendo consideradas normais as distribuições cujos valores desses desvios estivessem nos limites entre (2 e 2). Foram comparados os dados por sexo de cada Estado, aplicando-se o teste F ( $\alpha=$ 0,05), para comparação da razão das variâncias entre duas amostras, e o teste t, para comparação de médias $(\alpha=0,05)$ aos dados que apresentaram distribuição normal. $\mathrm{O}$ teste não-paramétrico de Wilcoxon-Mann-Whitney foi aplicado aos dados que não apresentaram distribuição normal.

Os dados de cada Estado, agrupados quando as diferenças entre sexos não foram significativas, foram comparados entre si. Aplicou-se, então, o teste de Bartlett, para verificação da homocedasticidade das variâncias. Assim, quando as variâncias foram iguais, compararam-se as médias de todas amostras através da análise de variância - ANOVA, e o teste de Tukey, para comparações múltiplas. Quando as variâncias foram heterocedásticas, foi aplicado o teste de análise de variância nãoparamétrica de Kruskal-Wallis e um teste de comparações múltiplas apropriado (Zar, 1999).

\subsection{Estrutura de comprimentos}

Os dados de comprimento anal (La) de T. lepturus, obtidos nos desembarques, foram agrupados em classes de $20 \mathrm{~mm}$ para análise da estrutura de comprimentos das 
capturas mensais, verificando-se o deslocamento temporal de modas, indicações sobre o crescimento de coortes na população.

\subsection{Relações Biométricas}

Verificou-se a normalidade dos dados de comprimento total (Lt) e peso (Wt) por sexo dos exemplares de T. lepturus de cada Estado através do cálculo de simetria e curtose, e respectivos desvios estandartizados. Aos dados que apresentaram distribuição normal, aplicou-se o teste $\mathrm{F}\left(\alpha_{2}=0,05\right)$, para comparação da razão das variâncias entre duas amostras, e o teste $t$, para comparação de médias $\left(\alpha_{2}=0,05\right)$. O teste nãoparamétrico de Wilcoxon-Mann-Whitney foi aplicado àqueles que não apresentaram distribuição normal. Os dados de comprimento total e peso por sexo para cada Estado foram descritos por gráficos de densidade tipo boxplot.

Utilizando-se o método dos mínimos quadrados, testaram-se os modelos linear $\left(y=a+b^{*} x\right)$ e potencial $\left(y=a^{*} x^{b}\right)$, para as relações entre comprimento total e comprimento anal, e comprimento anal e comprimento total, por sexo e agrupados. Analisando-se os resíduos de cada modelo e a normalidade destes, bem como os desvios de cada parâmetro e os coeficientes de determinação, optou-se pelo modelo potencial. Tais relações permitiram a conversão dessas medidas possibilitando comparações com a literatura disponível.

Com a finalidade de detectar possíveis relações e interações entre o sexo e os comprimentos anal (La) dos exemplares, foram realizadas análises de covariância (ANCOVA) para cada Estado, sendo o comprimento total a variável dependente e o sexo como variável categórica, segundo os modelos abaixo:

Comprimento total $(\mathrm{Lt})=$ constante + Comprimento anal $(\mathrm{La})+\operatorname{sexo}+$ sexo $*$ (La)

Comprimento total $(\mathrm{Lt})=$ constante + Comprimento anal $(\mathrm{La})+$ sexo com nível de significância $(\mathrm{p}<0,05)$. Foram calculados os coeficientes de correlação $(r)$ e de determinação $\left(\mathrm{r}^{2}\right)$.

O peso total dos exemplares de cada Estado foram relacionados ao comprimento total dos mesmos, por sexo e agrupados, ajustando-se o modelo potencial $\left(y=a^{*} x^{b}\right)$ através do método não-linear de mínimos quadrados. As curvas resultantes 
foram comparadas utilizando-se a razão de verossimilhança máxima, na qual são testadas as hipóteses de curvas coincidentes, interceptos iguais ou inclinações iguais (Kimura, 1980; Cerrato, 1990; Haddon, 2001).

\subsection{Reprodução}

Baseando-se na metodologia descrita por Vazzoler (1996), adaptou-se aqui uma escala macroscópica de estádios de maturidade dos exemplares a fresco de $T$. lepturus, como descrito a seguir com referência às fêmeas:

Estádio A: a gônada apresenta-se filiforme, de cor alaranjada, transparente, e colada à parede dorsal, esta representa uma "fêmea imatura".

Estádio B: a gônada ocupa $1 / 3$ da cavidade celomática, aparência firme, opaca de cor laranja claro, com rede capilar pouco intensa e ovócitos pequenos facilmente visíveis a olho nu, denominada "em maturação".

Estádio C: a gônada ocupa de 2/3 a quase toda a cavidade celomática, sendo observados ovócitos grandes, porém não completamente hidratados, denominada "madura".

Estádio $\mathrm{C} / \mathrm{H}$ : a gônada ocupa toda a cavidade celomática, com ovócitos hidratados e translúcidos, indicando desova iminente, denominada "fêmea hidratada".

Estádio C/D: a gônada ocupa quase toda a cavidade celomática, porém sua consistência tende à flacidez. Ovócitos grandes ainda são observados e liberados com leve pressão abdominal indicando estar em estádio de pós-desova, denominadas como "recém-desovadas".

Estádio D: a gônada ocupa 1/3 a 2/3 da cavidade celomática, consistência flácida, de cor laranja escuro, indicando estar em estádio de recuperação.

Para machos, utilizou-se uma escala similar, porém com maior dificuldade na distinção entre os estádios, sendo levado em consideração principalmente o tamanho, coloração da gônada, e resistência na liberação do esperma sob pressão, sendo:

Estádio A: a gônada é filamentosa e esbranquiçada, denominada "imatura". 
Estádio B: a gônada ocupa 1/3 da cavidade celomática, aparência firme, opaca de cor branco-leitoso, não liberando nenhuma substância ao ser pressionada, denominada "em maturação".

Estádio C: a gônada ocupa de $2 / 3$ a quase toda a cavidade celomática, aspecto firme e branco leitoso, com pouca liberação de sêmen sob pressão, denominada "madura".

Estádio C/D: a gônada ocupa quase toda a cavidade celomática, porém sua consistência tende à flacidez. Opaca, e cor creme, as bordas apresentam-se por vezes cor laranja escuro, aparentando ressecamento. Fácil liberação de esperma, sendo denominada "recém-esvaziada".

Estádio D: a gônada ocupa 1/3 a 2/3 da cavidade celomática, consistência flácida, de cor creme escuro leitoso, indicando período de recuperação.

O reconhecimento dos estádios de maturidade seria dificultado, até mesmo para as fêmeas, se os exemplares estivessem conservados em formol.

Verificou-se a proporção mensal de fêmeas em cada Estado analisado. Foram também analisadas a composição sexual por classe de comprimento e a ocorrência de jovens e adultos no período.

Os valores de peso das gônadas $(\mathrm{Wg})$ por estádio de maturidade foram plotados em gráficos de densidade tipo boxplot.

A época de desova foi verificada através de análises:

* qualitativa - distribuição mensal dos estádios de maturidade por sexo;

* quantitativa: 1) variação temporal da relação gonadossomática (RGS) das fêmeas:

$$
\mathrm{RGS}_{1}=\mathrm{Wg} * 100 / \mathrm{Wt} ; \quad \mathrm{RGS}_{2}=\mathrm{Wg}^{*} 100 / \mathrm{Wc}
$$

2) variação temporal do fator de condição alométrico $(K)$ :

$$
\mathrm{K} \text {-total }=\mathrm{K}=\mathrm{Wt} / \mathrm{Lt}^{\mathrm{b}} ; \quad \mathrm{K} \text {-somático }=\mathrm{K}^{\prime}=\mathrm{Wc} / \mathrm{Lt}^{\mathrm{b}}
$$

3) variação temporal do índice gonadal (IG):

$$
\mathrm{IG}=\mathrm{Wg} / \mathrm{Lt}^{\mathrm{b}}
$$

sendo Wg peso da gônada;

$\mathrm{Wt}=$ peso total;

$\mathrm{Wc}=$ peso do corpo $(\mathrm{Wc}=\mathrm{Wt}-\mathrm{Wg})$;

$\mathrm{Lt}=$ comprimento total;

$\mathrm{b}=$ coeficiente angular da relação peso-comprimento. 
Os valores de IG mensais foram descritos em gráficos de densidade tipo boxplot. Os valores médios mensais de $\mathrm{RGS}_{1}$ e $\mathrm{RGS}_{2}$, bem como os valores médios de $\mathrm{K}$ e $\mathrm{K}$ ' foram plotados em gráfico, para verificação da época de maior diferença entre esses índices, diferença esta devida ao peso da gônada, dando indicações do período de desova (Vazzoler, 1996).

O comprimento médio de primeira maturação gonadal $\left(\mathrm{L}_{50}\right)$, no qual $50 \%$ dos indivíduos constituintes de uma população entram ativamente na fase adulta, foi obtido pela agregação dos indivíduos considerados maduros em distribuições de freqüências relativas de comprimento total, ajustadas pelo método dos mínimos quadrados (iterativo) em uma curva logística de forma:

$$
\mathrm{Pi}=1 /\left[1+\mathrm{e}^{-\mathrm{r} *\left(\mathrm{Lt}-\mathrm{L}_{50}\right)}\right]
$$

sendo: $\mathrm{Pi}=$ freqüência relativa esperada de indivíduos maduros na classe " $\mathrm{i}$ " de $\mathrm{Lt}$

$\mathrm{Lt}=$ comprimento total na classe $\mathrm{i}$

$\mathrm{r}=$ parâmetro de curvatura

$\mathrm{L}_{50}=$ comprimento médio de primeira maturação gonadal

As curvas obtidas em cada Estado foram comparadas pela razão de verossimilhança máxima (Kimura, 1980; Cerrato, 1990; Haddon, 2001).

O tipo de desova da espécie foi verificado através da mensuração do diâmetro dos ovócitos de amostras das gônadas de fêmeas maduras (estádios $\mathrm{C}$ e $\mathrm{C} / \mathrm{H}$ ), que foram lançados em histogramas de distribuição de freqüência. Os ovócitos foram fotografados sob estereomicroscópio OPTECH-SZ acoplado a uma câmera digital GKB-CC-9603 com luz incidente, utilizando-se o software Pinnacle PCTV Vision. Para mensuração dos ovócitos utilizou-se o programa ImageTool (UTHSCSA, 1996).

A fecundidade relativa da espécie foi obtida através da contagem de ovócitos maduros e/ou hidratados presentes em três amostras de porções distintas de cada gônada de fêmea madura, extrapolada para o total da gônada. Através do ajuste de modelo potencial pelo método dos mínimos quadrados, foram obtidas as relações entre fecundidade e as variáveis de peso e comprimento dos exemplares de cada Estado, e comparadas por razão de verossimilhança máxima. 


\subsection{Idade e Crescimento}

Para o estudo do crescimento de T. lepturus foram analisados os otólitos "sagitae" dos exemplares de cada Estado. Foram escolhidos cerca de 5 exemplares por classe de comprimento e sexo para o estudo do crescimento, perfazendo 424 pares de otólitos, sendo 221 de fêmeas, 169 de machos e 34 não identificados.

Os otólitos direito e esquerdo de cada exemplar foram pesados (Wo, 0,001g) e medidos em comprimento (Lo, $\mathrm{mm}$ ) e altura (Ho, mm). Para cada conjunto de dados, agrupados por sexo, foi testada sua normalidade, e aplicados os testes $\mathrm{t}$ e WilcoxonMann-Whitney pareados, para os que apresentaram distribuição normal ou não, respectivamente, verificando-se diferenças entre as estruturas de cada indivíduo. Os dados de comprimento e largura dos otólitos foram relacionados ao comprimento total dos exemplares pelo modelo linear, e o peso dos otólitos foi relacionado ao comprimento total pelo modelo potencial, ambos modelos ajustados pelo método dos mínimos quadrados. Os coeficientes linear e angular das regressões lineares foram comparados entre sexos e Estados através da análise de covariância - ANCOVA (Zar, 1999). As curvas obtidas nas relações peso do otólito e comprimento total foram comparadas pela razão de verossimilhança máxima.

Os otólitos esquerdos foram previamente observados sob estereomicroscópio OPTECH-SX para demarcação da região do núcleo da estrutura. Em seguida, foram emblocados em resina acrílica para obtenção de cortes transversais da região do núcleo com cerca de $0,3 \mathrm{~mm}$, utilizando-se serra metalográfica de baixa rotação (ISOMET Buehler) e lâmina diamantada. Os cortes foram lixados delicadamente com lixa d'água 2000 e afixados em lâminas com bálsamo do Canadá.

Os cortes foram fotografados em sistema de análise de imagens com câmera digital GKB-CC-9603 acoplada ao estereomicroscópio OPTECH-SZ, com luz transmitida e aumento de 18 vezes, utilizando-se o software Pinnacle PCTV Vision. Para observação e mensuração dos cortes dos otólitos utilizou-se o programa ImageTool (UTHSCSA, 1996).

A idade relativa foi determinada pela contagem do número de conjuntos de anéis translúcido e opaco adjacente. Considerou-se raio do anel de crescimento (Ri) à distância entre o núcleo dos otólitos e a borda externa de cada anel opaco, e raio total (Rt), à distância entre o núcleo e a borda dorsal do otólito seccionado. Foram efetuadas 
duas leituras em ordem aleatória, sem o conhecimento prévio do comprimento anal ou total do exemplar, a intervalos de tempo de pelo menos duas semanas entre uma leitura e outra. A terceira leitura foi efetuada para verificação dos otólitos cujas contagens anteriores foram discordantes. Os otólitos cujas leituras mesmo assim não foram coincidentes foram descartados e trocados por outros de exemplares de tamanho e sexo equivalentes. O tipo de bordo de cada otólito (opaco ou translúcido) foi verificado.

Os valores obtidos para os raios de cada anel observado nos otólitos de $T$. lepturus de cada Estado foram lançados em gráficos de densidade do tipo boxplot, para verificação de seu deslocamento crescente com o aumento do número de anéis. A constância na distância de cada anel em relação ao núcleo, seja qual for a idade do peixe, foi verificada plotando-se as médias e respectivos desvios de cada raio de anel por seu número máximo de anéis.

Para que a leitura acima reflita a idade real do peixe de maneira satisfatória, é necessário validar a formação dos anéis de crescimento. A validação consiste na determinação da época e periodicidade da formação dos anéis de crescimento, através da análise da:

- proporção mensal de bordo translúcido e opaco observada nos otólitos;

- média mensal de incremento marginal:

$$
\mathrm{IM}=\left(\mathrm{R}_{\mathrm{o}}-\mathrm{R}_{\mathrm{i}}\right) /\left(\mathrm{R}_{\mathrm{i}}-\mathrm{R}_{\mathrm{i}-1}\right)
$$

onde $\quad \mathrm{R}_{\mathrm{o}}=$ distância do núcleo ao bordo da estrutura;

$\mathrm{R}_{\mathrm{i}}=$ distância do núcleo ao último anel;

$\mathrm{R}_{\mathrm{i}-1}=$ distância do núcleo ao penúltimo anel.

Uma vez validados, os dados de número de anéis e época de formação puderam ser convertidos em idade, obtendo-se o comprimento médio para cada idade pela média de comprimentos dos exemplares com o mesmo número de anéis de crescimento.

Utilizou-se o modelo de von Bertalanffy para descrição do crescimento de $T$. lepturus por sexo e agrupados, conforme a equação:

$$
\mathrm{Lt}=\mathrm{L}_{\mathrm{oo}} *\left[1-\mathrm{e}^{-\mathrm{k} *(\mathrm{t}-\mathrm{t})}, 0\right.
$$

sendo $\mathrm{Lt}=$ comprimento total $(\mathrm{mm})$ na idade $\mathrm{t}$

$\mathrm{L}_{\mathrm{oo}}=$ comprimento máximo assintótico $(\mathrm{mm})$;

$\mathrm{k}=$ taxa de crescimento (/ano); 
$\mathrm{t}=$ idade $(\operatorname{anos})$

$\mathrm{t}_{0}=$ idade teórica no comprimento zero (anos).

Diversos conjuntos de dados de comprimento total por idade foram utilizados para a estimativa dos parâmetros acima por sexo. O primeiro conjunto referiu-se aos dados individuais de comprimento total por idade (OtolTot), obtidos através da leitura de anéis de crescimento nas secções dos otólitos. O segundo conjunto foi formado pelas médias ponderadas desses comprimentos individuais por idade (OtolMéd). $\mathrm{O}$ terceiro conjunto utilizou os dados individuais de comprimento total retrocalculados para cada idade (RetroTot). O quarto conjunto abrangeu os comprimentos retrocalculados médios para cada idade (RetroMéd).

A técnica de retrocálculo usa o comprimento do peixe à época de captura para inferir seu comprimento em idades anteriores, à época de formação de cada anel etário. É muito utilizada para aumentar o tamanho amostral dos dados de comprimento por idade e preencher as lacunas nos dados com relação às idades raramente observadas (Francis, 1990). Este método pode ser utilizado desde que haja dependência entre o crescimento do corpo e da estrutura rígida em estudo.

Para verificar qual modelo melhor representaria a dependência entre $\mathrm{o}$ crescimento do peixe e o crescimento do raio total do otólito em $T$. lepturus, foram testados os modelos: linear, potencial e logístico, conforme as equações:
I. Linear:
$\mathrm{Lt}=\mathrm{a}+\mathrm{b}^{*} \mathrm{Rt}$
II. Potencial:
$\mathrm{Lt}=\mathrm{a}^{*} \mathrm{Rt}$
III. Logístico:
$\mathrm{Lt}=\mathrm{a} / 1+\mathrm{b} * \mathrm{c}^{\mathrm{Rt}}$

(Ávila-da-Silva, 2002)

onde: $\mathrm{Lt}=$ comprimento do peixe

$\mathrm{Rt}=$ raio total

$\mathrm{a}, \mathrm{b}, \mathrm{c}=$ parâmetros das equações

Todos os parâmetros das diversas equações foram estimados por iteração, baseada no algoritmo derivado por Levenberg \& Marquardt, utilizando-se o método dos mínimos quadrados (Gauss-Newton). A escolha da função que melhor se adequou aos dados foi baseada nos testes de normalidade dos resíduos de cada modelo.

Os comprimentos totais foram então retrocalculados, baseados na hipótese de “corpo proporcional”, na qual o comprimento do peixe é a variável dependente na relação (Francis, op. cit.), segundo a função logística: 


$$
\mathrm{Lti}=\left(\mathrm{a} / 1+\mathrm{b} * \mathrm{c}^{\mathrm{Ri}}\right) * \mathrm{f}
$$

onde: $\mathrm{Lti}=$ comprimento retrocalculado na idade $\mathrm{i}$

$\mathrm{Ri}=$ raio do anel na idade $\mathrm{i}$

a, b, c = parâmetros da relação comprimento total $(\mathrm{Lt})$ e raio total $(\mathrm{Rt})$

$\mathrm{f}=$ razão entre o comprimento total observado $(\mathrm{Lt})$ e o comprimento total estimado $\left(\mathrm{Lt}_{\text {est }}\right)$ na equação entre comprimento total e raio total, sendo $\mathrm{f}=\mathrm{Lt}$ / $\mathrm{Lt}_{\mathrm{est}}$

A cada estimativa de parâmetros de crescimento foi calculado o índice de performance de crescimento ф' (Gayanilo \& Pauly, 1997):

$$
\phi^{\prime}=\log \mathrm{k}+2 * \log \mathrm{L}_{\mathrm{oo}}
$$

que compara a performance de crescimento da espécie para diferentes valores de parâmetros. Valores muito diferentes entre si podem indicar erros na estimativa dos parâmetros de crescimento.

Utilizando-se a razão de verossimilhança máxima, com nível de significância de $5 \%$, foram comparadas as curvas do modelo de von Bertalanffy obtidas para cada sexo usando-se os conjuntos OtolTot e RetroTot. Com o conjunto OtolTot, comparou-se os sexos de cada Estado e entre Estados

$\mathrm{O}$ peso máximo assintótico $\left(\mathrm{W}_{\mathrm{oo}}\right)$ foi calculado através da relação pesocomprimento por sexo e agrupados para cada Estado.

A proporção de cada grupo etário por classe de comprimento $(50 \mathrm{~mm})$ foi utilizada para elaboração das chaves idade-comprimento da espécie.

\subsection{Mortalidade}

A taxa de mortalidade total $(Z)$ foi calculada pelo método de Curva de Captura de comprimentos convertidos em idade, que se baseia nos dados de composição em comprimento do capturado (Sparre \& Venema, 1998). Este método relaciona o logaritmo natural da razão entre freqüência absoluta por classe de comprimento no capturado pelo tempo de vida gasto em cada classe (ln $\mathrm{C}(\mathrm{L} 1, \mathrm{~L} 2) / \Delta \mathrm{t}(\mathrm{L} 1, \mathrm{~L} 2))$, e a idade estimada para o comprimento médio de cada classe de comprimento [t((L1+L2)/2)]. Desta relação, ajusta-se o modelo linear a pontos escolhidos no lado descendente da curva (comprimentos totalmente explotados na pesca), onde o valor da mortalidade total 
(Z) será o inverso do valor obtido para a inclinação da reta (b). Este método foi aplicado aos dados mensais de freqüência de comprimento anal (convertidos em comprimento total) obtidos no período amostrado em cada Estado, ponderados pelas capturas mensais disponíveis para cada arte de pesca analisada. Os comprimentos totais foram convertidos em idade utilizando-se os parâmetros de crescimento do modelo de von Bertalanffy obtidos com o conjunto OtolTot para sexos agrupados. Para escolha do número de pontos do braço descendente da curva acima descrita, foram calculadas várias retas com diferentes números de pontos, escolhendo-se aquela cujo intervalo de confiança (IC) fosse menor (Sparre \& Venema, 1998). As inclinações (b) das retas obtidas em cada Estado foram comparadas por análise de covariância (ANCOVA) e, uma vez significativamente diferentes, foi aplicado o teste de comparação múltipla para as inclinações (Zar, 1999).

A mortalidade total $(Z)$ foi também estimada pelo método descrito por Ssentongo \& Larkin (1973) para peixes tropicais, segundo a equação:

$$
\mathrm{Z}=\mathrm{N} *(\mathrm{k} / \mathrm{N}+1) * \ln \left(\left(\mathrm{L}_{\mathrm{oo}}-\mathrm{Lc}\right) /\left(\mathrm{L}_{\mathrm{oo}}-\mathrm{Lméd}\right)\right)
$$

Onde: $\mathrm{N}=$ número total da amostra

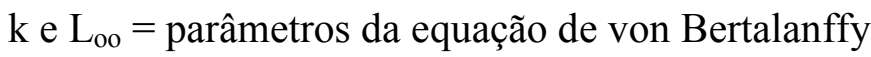

$\mathrm{Lc}=$ comprimento médio de primeira captura

Lméd $=$ comprimento médio do capturado acima de Lc

O comprimento de primeira captura (Lc) foi estimado através do pacote computacional FISAT II (versão 1.1.0), que apresenta uma subrotina para estimativa da mortalidade total pelo método de curva de captura. Esta também fornece as probabilidades de captura por classes de comprimento, a partir da qual o programa estima os valores de Lc (= L50), ajustando uma curva logística às freqüências acumuladas dessas probabilidades (Gayanilo \& Pauly, 1997).

As taxas de sobrevivência foram estimadas pela equação: $S=\mathrm{e}^{-Z}$.

Valores de mortalidade natural (M) foram obtidos utilizando-se equações de vários autores (in Sparre e Venema, 1998), a saber:

Fórmula empírica de Pauly (1980), com correção de 20\% para formação de cardumes:

$$
\log _{10} \mathrm{M}=0,8 *\left(-0,0066-0,279 \log _{10} \mathrm{~L}_{\mathrm{oo}}+0,6543 \log _{10} \mathrm{k}+0,4634 \log _{10} \mathrm{~T}\left({ }^{\circ} \mathrm{C}\right)\right)
$$


Alagaraja: $\quad M=-\ln (0,01) / \operatorname{Tmax}$

Hoenig: $\quad \operatorname{Ln} M=1,45-1,01 * \ln T \operatorname{Tmax}$

Rikter \& Efanov $\quad M=\left(\left(1,52 / T_{50}\right) \cdot 0,72\right)-0.16$

onde: $\quad \mathrm{L}_{\mathrm{oo}}=$ comprimento máximo assintótico $(\mathrm{em} \mathrm{cm})$;

$\mathrm{k}=$ taxa de crescimento $\left(\right.$ ano $\left.^{-1}\right)$;

$\mathrm{T}\left({ }^{\circ} \mathrm{C}\right)=$ temperatura média anual da água - considerada $24^{\circ} \mathrm{C}$.

Tmáx $=$ longevidade (anos), pela equação: $\quad \operatorname{Tmax}=\mathrm{t}_{0}+2,996 / \mathrm{k}$;

$\mathrm{t}_{0}=$ idade teórica no comprimento zero (anos)

$\mathrm{T}_{50}=$ idade de primeira maturação sexual, correspondente ao $\mathrm{L}_{50}$ (comprimento de primeira maturação sexual).

A mortalidade por pesca (F) foi obtida pela diferença entre a mortalidade total e a natural $(\mathrm{F}=\mathrm{Z}-\mathrm{M})$.

\subsection{Rendimento e Biomassa Relativos por Recruta}

O modelo de rendimento relativo por recruta, desenvolvido por Beverton \& Holt (1966 in Sparre \& Venema, 1998), foi estimado pela equação:

sendo:

$$
\mathrm{Y}^{\prime} / \mathrm{R}=\mathrm{E} * \mathrm{U}^{\mathrm{M} / \mathrm{k}} *\left[1-(3 \mathrm{U} / 1+\mathrm{m})+\left(3 \mathrm{U}^{2} / 1+2 \mathrm{~m}\right)-\left(\mathrm{U}^{3} / 1+3 \mathrm{~m}\right)\right]
$$

$$
\begin{aligned}
& \mathrm{m}=(1-\mathrm{E}) /(\mathrm{M} / \mathrm{k})=\mathrm{k} / \mathrm{Z} \\
& \mathrm{U}=1-\mathrm{Lc} / \mathrm{L}_{\mathrm{oo}} \\
& \mathrm{E}=\mathrm{F} / \mathrm{Z}
\end{aligned}
$$

onde: $\mathrm{E}=$ taxa de explotação;

$\mathrm{M}=$ mortalidade natural $\left(\mathrm{ano}^{-1}\right)$;

$\mathrm{F}=$ mortalidade por pesca $\left(\mathrm{ano}^{-1}\right)$;

$\mathrm{Z}=$ mortalidade total $\left(\mathrm{ano}^{-1}\right)$;

$\mathrm{k} \mathrm{e}_{\mathrm{oo}}=$ parâmetros do modelo de crescimento de von Bertalanffy;

$\mathrm{Lc}=$ comprimento médio $(\mathrm{mm})$ de primeira captura.

A biomassa relativa por recruta foi obtida pela equação: $B^{\prime} / R=\left(Y^{\prime} / R\right) / F$

Determinou-se as curvas de $\mathrm{Y}^{\prime} / \mathrm{R}$ e $\mathrm{B}^{\prime} / \mathrm{R}$ versus $\mathrm{E}$ alterando-se os valores de $\mathrm{E}$ entre de 0 a 1, que corresponde aos valores de $\mathrm{F}$ de 0 a $\infty$. 
Os valores de $E_{\max }$ e $E_{0.1}$ foram obtidos através da subrotina para estimativa de rendimento relativo por recruta do pacote computacional FISAT II (versão 1.1.0). Os pontos de referência biológica $\mathrm{F}_{\max }$ e $\mathrm{F}_{0.1}$ foram obtidos numericamente encontrando-se as taxas de mortalidade por pesca nas quais a inclinação da curva de rendimento relativo por recruta $\left(\mathrm{Y}^{\prime} / \mathrm{R}\right)$ fosse zero e $10 \%$ da inclinação inicial, respectivamente, através da derivação da equação de Y'/R (Gayanilo \& Pauly, 1997).

Os valores $\mathrm{E}_{\max }$ e $\mathrm{F}_{\max }$ referem-se à taxa de explotação e mortalidade por pesca no rendimento máximo sustentável (MSY) respectivamente. Os valores $\mathrm{E}_{0.1}$ e $\mathrm{F}_{0.1}$ referem-se, respectivamente, à taxa de explotação e mortalidade por pesca no ponto da curva $Y^{\prime} / R$ onde o valor da inclinação é $10 \%$ do valor original. 


\section{RESULTADOS}

\section{A Pesca de Trichiurus lepturus - Dados estatístico-pesqueiros}

\section{$\underline{\text { Rio de Janeiro }}$}

A produção pesqueira da região de Arraial do Cabo (RJ) no período de 1992 a 2002 atingiu $18.994 \mathrm{t}$, com captura média anual de 1.727 t ( $\mathrm{dp} \pm$ 617). As maiores capturas ocorreram em 1999/2000, excluindo-se o ano de 1995, com descargas da pesca comercial nesse cais que foram englobadas com a pesca artesanal (Azevedo, 2004). O esforço aplicado em todas as artes no período, padronizado em horas de pesca, correspondeu a $527.286 \mathrm{~h}$, apresentando média anual de $47.935 \mathrm{~h}$ (dp \pm 13.183). De maneira geral, o aumento do esforço de pesca implicou em aumento da produção local (Figura 20), excetuando-se 1995 pelos motivos descritos acima. A CPUE no período manteve-se ao redor de $30 \mathrm{~kg} / \mathrm{h}$, exceto nos anos de 1995 e 1996, quando atingiu picos ao redor de $65 \mathrm{~kg} / \mathrm{h}$, devido a alta captura em 1995 e o menor esforço de pesca em 1996, o que resultou em desvios negativos da média de CPUE no período para todos os demais anos (Figura 21).

Foram capturadas 107 espécies no período analisado, sendo $90 \%$ do total pertencente a apenas 16 espécies, principalmente peixes pelágicos (Figura 22). A produção do espada Trichiurus lepturus não ultrapassava 5\% do total até 1995, quando apresentou importância crescente, tornando-se a principal espécie a partir de 1999, atingindo 35\% da captura em 2001 (Figura 23). A CPUE da espécie variou de 0,33 a $12,66 \mathrm{~kg} / \mathrm{h}$, com média de $5,03 \mathrm{~kg} / \mathrm{h}( \pm 4,12)$ no período. As médias anuais apresentaram desvios sempre positivos a partir de 1998 (Figura 24).

\section{$\underline{\text { São Paulo }}$}

Foram disponibilizados os dados de 8.973 desembarques efetuados ao longo da costa de São Paulo (Guarujá, Ubatuba e Santos), pelo Instituto de Pesca/APTA/SAA/SP, abrangendo a pesca comercial e artesanal no período de 1998 a 2004. Destes, 6018 desembarques apresentaram a espécie T. lepturus em suas capturas (Tabela 02). 
Verificou-se que a captura de espada aumentou a partir do ano 2000, oscilando desde então ao redor de 3,5\% da produção total (Figura 25).

Analisando-se as proporções mensais de espada na captura total nesse período, observou-se a tendência de maior captura da espécie no período de dezembro a junho em todos os anos analisados, exceto em 1998, quando as menores proporções foram verificadas nos primeiros meses do ano (Figura 26). A mesma tendência é verificada quando se analisa a proporção mensal de capturado em relação ao total anual da espécie, havendo, portanto menor captura da mesma nos meses referentes ao inverno (Figura 27).

O número de desembarques que apresentaram espada para cada arte de pesca está apresentado na figura 28. A maior produção de espada foi obtida na pesca comercial de arrasto de fundo com parelha, correspondendo a $61,8 \%$ da produção total da espécie no período, enquanto apenas $32,7 \%$ desta foi verificada nas demais artes. Entretanto, em termos proporcionais, o espada representou apenas 3,3\% do total capturado por parelhas, predominando na arte de pesca artesanal de linha-de-mão $(57,1 \%)$ (Figura 29).

Assim, foram efetuadas análises do direcionamento da atividade pesqueira anual das artes de pesca de linha-de-mão e parelha. No arrasto de parelha, verificou-se o formato fortemente convexo da curva de freqüência acumulada. Isto indica que a espécie pouco contribuiu para cada desembarque, pois em $80 \%$ destes não atingiu participações relativas superiores a $2 \%$ em qualquer ano analisado, sendo considerada espécie acessória (Tabela 03 e Figura 30). Na pesca artesanal de linha-de-mão, desenvolvida na região de Ubatuba (SP), a participação do espada oscilou no período analisado, porém nunca apresentou participação relativa inferior a 30\%, observado em 2002 e 2004. Excetuando-se esses anos, a espécie pode ser considerada alvo da pescaria, com contribuições ao redor de $50 \%$ ou mais, verificado no formato côncavo das curvas resultantes (Tabela 03 e Figura 31).

A pesca de arrasto com parelhas atuou na faixa de 15 a $60 \mathrm{~m}$ de profundidade, e apresentou tendências crescentes na captura e esforço da frota no período estudado (Figuras 32 e 33). Até o ano de 2001, as maiores capturas de espada foram verificadas no $4^{\mathrm{o}}$. bimestre, e a partir de 2002, no $1^{\mathrm{o}}$. bimestre, envolvendo os períodos de primavera-verão. Os maiores esforços de pesca da frota foram aplicados principalmente no $2^{\circ}$. bimestre de diversos anos do período, não refletindo as maiores capturas da espécie; pelo contrário, as maiores CPUEs de espada foram verificadas no $4^{\circ}$. bimestre 
até 2000 e a partir daí, no $1^{\circ}$. bimestre, mesmo padrão observado para as capturas (Figura 34). Analisando-se as variações das medianas trimestrais das capturas em relação à média destas no período, verifica-se que valores acima da média do período ocorrem principalmente a partir de 2001, na primeira metade dos anos (Figura 35). Menor variação foi verificada com relação às medianas de esforço de pesca, exceto em 2004, onde foram verificados valores acima da média do período em todos os trimestres (Figura 36). A mesma tendência das capturas foi observada para as CPUEs da espécie. Valores superiores à média do período foram verificados principalmente a partir de 2001, nos primeiros semestres (Figura 37).

\section{$\underline{\text { Santa Catarina }}$}

A produção dos três cercos flutuantes da Empresa Pioneira da Costa S/A, localizados na região de Porto Belo (SC) foi de $90.667 \mathrm{~kg}$, com média mensal de 8.242 $\mathrm{kg}(\mathrm{dp} \pm 5900)$. A maior produção foi verificada principalmente de julho a outubro e em fevereiro. O esforço aplicado totalizou 166 dias de pesca, variando de 12 a 20 dias, excetuando-se os meses de defeso da tainha, com média de 15,1 dias $(\mathrm{dp} \pm 3,83)$ (Figura 38). Foram capturadas trinta espécies no período, com apenas 8 delas atingindo $96,6 \%$ da captura total. O espada Trichiurus lepturus foi responsável por 73,6\% da captura no período, com maior participação no segundo semestre (Tabela 04 e Figuras 39 e 40). A CPUE média da espécie para o período foi de 554,6 kg ( $\mathrm{dp} \pm 386$ ), com maiores valores observados nos meses de julho e agosto de 2002. A CPUE da espécie apresentou desvios acima da média (positivos) nos meses de julho a novembro de 2002 (Figura 41).

\section{Diversidade genética intra e inter populacional}

Após vários meses de dificuldades com a padronização das amostras de DNA, devido ao alto grau de degradação em que se encontravam, conseguiu-se amplificações satisfatórias de DNA de espada com a técnica RAPD/PCR. A figura 42 apresenta um exemplo do resultado da extração de DNA de algumas amostras, onde se verifica o rastro resultante das inúmeras bandas formadas pelo DNA degradado em concentrações diversas. A figura 43 apresenta, como exemplo, os resultados obtidos da eletroforese do primer 01 nas amostras dos diferentes Estados analisados. 
Foram obtidas 38 marcas polimórficas (bandas) distintas com os primers utilizados nas amplificações dos 108 exemplares de T. lepturus analisados (18 por região), as quais variaram de 550 a 1800 pb. Verificou-se a ocorrência de uma banda exclusiva da região de Belém, e outra banda exclusiva das demais regiões.

$\mathrm{Na}$ análise molecular de variância (AMOVA), obteve-se $\Phi$ st $=0,044$ (significativamente diferente de zero), o que indica diferenciação genética entre as regiões amostradas. Examinando-se a diferenciação genética das regiões pareadas, os maiores valores de $\Phi$ st foram obtidos nos pares que envolviam a região de Belém (PA) $(\Phi s t>0,05)$ (Tabela 05A e B).

Analisando-se o dendrograma obtido para os coeficientes de similaridade de Jaccard entre os exemplares de T. lepturus, verifica-se a formação de dois grandes grupos no dendrograma (Figura 44). O primeiro formado por exemplares exclusivamente da região de Belém e o outro grande grupo envolveu os exemplares das demais regiões. Entretanto, a análise de bootstrap indicou robustez apenas no grupo de Belém, com valores superiores a $40 \%$. Valores inferiores a $20 \%$ foram verificados nos demais nós do dendrograma, indicando que todo o segundo grupo apresenta grande diversidade gênica em toda a região ao sul de Natal. Os valores superiores a $20 \%$ foram apresentados para os demais nós do dendrograma.

A matriz das distâncias genéticas de Ney, obtida para as regiões pareadas, resultou num dendrograma semelhante ao anterior, onde todas as regiões ao sul de Natal apresentaram alta identidade entre si, sendo agrupadas com 97\% de confiança, enquanto que a região de Belém apresentou alto valor de distância genética com os demais grupos, ficando isolada (Figura 45 e Tabela 06).

\section{Dados merísticos}

O número de espinhos na primeira nadadeira dorsal não apresentou variação entre os diversos locais analisados, permanecendo constante em 3 espinhos. O mesmo foi observado com os raios da nadadeira peitoral, que apresentaram 11 raios em qualquer região analisada.

Os raios da segunda nadadeira dorsal apresentaram variações entre sexos e regiões, e suas descrições de amostra estão apresentadas na tabela 07. A distribuição dos dados apresentou-se normal em todos os grupos. Verificou-se homocedasticidade entre 
os dados por sexo de cada região (Teste F), e as médias (teste t) diferiram apenas entre fêmeas e machos de Santa Catarina. Uma vez agrupados machos e fêmeas do Rio de Janeiro e São Paulo, compararam-se as variâncias dos grupos dos diferentes Estados (Bartlett), verificando-se diferença muito significativa entre suas variâncias, e o teste de Kruskal-Wallis, que também indicou diferença significativa entre elas (Tabela 08). Aplicando-se o teste de comparação múltipla não-paramétricos a posteriori desbalanceados, o grupo dos machos de Santa Catarina apresentou-se significativamente diferente dos grupos do Rio de Janeiro e São Paulo. Para o grupo das fêmeas de Santa Catarina, o teste não foi conclusivo, permanecendo intermediário entre os Estados mais ao norte e os machos de Santa Catarina (Tabela 09).

\section{Estrutura de comprimentos}

O comprimento anal dos exemplares, obtido mensalmente nos locais de desembarque, foi agrupado em classes de $20 \mathrm{~mm}$.

No Rio de Janeiro, foram medidos 4298 exemplares de janeiro/02 a julho/03, abrangendo as classes de 240 a $740 \mathrm{~mm}$. A ausência de exemplares de menor porte indica a seletividade do aparelho de pesca, que atua sobre os estratos dos maiores indivíduos da população. Evidência desse fato foi constatada em julho/03, quando foi obtida uma amostra de 194 exemplares da pesca de parelha na região, onde se verificou exemplares de 60 a $160 \mathrm{~mm}$ (Figura 46). As distribuições mensais apresentaram-se normais, uni ou bimodais, não havendo deslocamento de modas muito evidente ao longo do período, indicando também seletividade da arte de pesca. Os menores exemplares foram observados no fim do Outono e Inverno.

Em São Paulo, obteve-se o comprimento anal de 5485 exemplares de espada no período de janeiro/02 a junho/03, com amplitude de 40 a $720 \mathrm{~mm}$. Apesar dos pequenos exemplares da espécie serem descartados ao mar, obtiveram-se algumas amostras de indivíduos de pequeno porte principalmente entre Verão e Inverno. Segundo informações dos pescadores, o período de maior ocorrência destes é no início do ano (Verão). As distribuições mensais apresentaram-se normais, uni ou bimodais, com deslocamento de modas pouco mais evidente que no Rio de Janeiro (Figura 47).

Em Santa Catarina, foram medidos 3637 exemplares no período de janeiro/02 a junho/03, abrangendo de 60 a $640 \mathrm{~mm}$. As distribuições apresentaram-se normais, 
unimodais, com evidente deslocamento de modas. A ausência de exemplares de pequeno porte indica a seletividade da arte de pesca de cerco flutuante. Alguns exemplares pequenos foram obtidos no primeiro semestre, que segundo os pescadores são acidentais (Figura 48). Amostras da pesca de cerco comercial foram obtidas nos meses de abril e maio/02 e 03 e junho/03, devido ao defeso da tainha (Mugil sp.) quando são retirados os cercos flutuantes do mar.

\section{Relações Biométricas}

A descrição das amostras de comprimento total $(\mathrm{Lt}-\mathrm{mm})$ e peso total $(\mathrm{Wt}-\mathrm{g})$ dos exemplares de T. lepturus analisados em cada Estado por sexo estão apresentadas nas tabelas 10 e 11 . Os dados de comprimento total apresentaram distribuição não normal em sua maioria. No Rio de Janeiro não foram verificados exemplares indeterminados. Em São Paulo e Santa Catarina os exemplares indeterminados corresponderam a 5,25\% e $6,9 \%$ do total amostrado, respectivamente.

No Rio de Janeiro, as fêmeas foram maiores que machos tanto em comprimento (Wilcoxon-Mann-Whitney: $\mathrm{P}=8,57 \mathrm{e}-9$ ) quanto em peso (WilcoxonMann-Whitney: $\mathrm{P}=1,72 \mathrm{e}-8)$. Em São Paulo, não foram verificadas diferenças significativas entre comprimentos (Wilcoxon-Mann-Whitney: $\mathrm{P}=0,132$ ) e pesos (Wilcoxon-Mann-Whitney: $\mathrm{P}=$ 0,361) de fêmeas e machos. Em Santa Catarina, as fêmeas foram significativamente diferentes dos machos em comprimento (WilcoxonMann-Whitney: $\mathrm{P}=1,75 \mathrm{e}-7$ ) e peso (Wilcoxon-Mann-Whitney: $\mathrm{P}=3,57 \mathrm{e}-7$ ). As figuras 49 e 50 apresentam os gráficos de densidade tipo "boxplot" dos dados de comprimento e peso, respectivamente.

Os coeficientes lineares e angulares das relações entre comprimento anal e total, e comprimento total e anal, para cada Estado analisado, por sexo e agrupados (incluindo indeterminados), bem como seus desvios padrões e respectivos coeficientes de determinação $\left(\mathrm{r}^{2}\right)$, estão apresentados nas tabelas 12 e 13 . Os altos valores obtidos para os coeficientes de determinação $\left(\mathrm{r}^{2}\right)$ indicam alta correlação entre os comprimentos anal e total da espécie $T$. lepturus.

As análises de covariância dos modelos que relacionaram comprimento total (variável dependente), sexo (variável categórica), e comprimento anal (covariável) dos diferentes Estados analisados, estão apresentadas na tabela 14. Os comprimentos anais variaram significativamente $(\mathrm{P}<0,05)$, mas não foram verificadas variações 
significativas na interação comprimento anal e sexo e entre sexos, nos três Estados analisados.

Os coeficientes lineares e angulares das relações entre peso total e comprimento total, por sexo e agrupados, de cada Estado analisado, seus respectivos desvios padrões e coeficientes de determinação $\left(\mathrm{r}^{2}\right)$, estão apresentados na tabela 15 . Aplicando-se a razão de verossimilhança máxima, não foram verificadas diferenças significativas entre os sexos no Rio de Janeiro e Santa Catarina, sendo agrupados os dados para comparações posteriores com machos e fêmeas de São Paulo, separadamente. Diferenças muito significativas foram verificadas nas comparações entre Estados (Tabela 16).

As figuras 51 a 59 apresentam as relações comprimento anal e total, comprimento total e anal, e peso total e comprimento total, por sexo e agrupados, obtidas nos diferentes Estados, e seus respectivos diagramas de dispersão de resíduos.

\section{Reprodução}

A proporção entre sexos variou muito nas regiões analisadas. No Rio de Janeiro ocorreram fêmeas e machos na proporção 5:1 no período, com predominância de fêmeas em todos os meses. Os machos foram bem representados apenas em São Paulo, cuja proporção foi de praticamente 1:1 no período. Porém, a proporção de machos foi maior no verão e início de inverno. Em Santa Catarina, as fêmeas voltam a prevalecer em todos os meses, com proporção 3:1, no total do período (Tabela17).

Com relação à composição sexual por classe de comprimento anal, verificou-se que as fêmeas atingem tamanhos maiores em todas as regiões estudadas, pois somente estas ocorreram a partir de $540 \mathrm{~mm}$. Exemplares indeterminados ocorreram em São Paulo (5,25\%) e Santa Catarina (6,90\%) somente nas classes de menor tamanho (Figura $60)$, sendo em menor número no fim do inverno e primavera (Tabela 17).

Apenas 3\% dos exemplares amostrados no Rio de Janeiro eram jovens (estádio A - imaturos). Em São Paulo, esta proporção atinge 20,28\%, e em Santa Catarina, $12,07 \%$.

Nos gráficos de densidade tipo "boxplot” apresentados na figura 61, verifica-se nítida diferença entre os pesos das gônadas de fêmeas e machos por estádio de maturação gonadal. Os machos apresentaram variações bem menos conspícuas entre os estádios de maturação do que as fêmeas. Os maiores valores para fêmeas foram 
verificados em São Paulo, principalmente no estádio hidratado $(\mathrm{C} / \mathrm{H})$, seguidos por Santa Catarina. No Rio de Janeiro não foram observadas fêmeas hidratadas em todo o período de estudo, sendo aí verificados os maiores valores para os estádios B e C/D (em maturação e recém-desovadas).

Analisando-se a freqüência relativa mensal dos estádios de maturação gonadal (Figuras 62 e 63), verificou-se no Rio de Janeiro que as fêmeas apresentaram-se desovadas principalmente no segundo semestre, onde a quase totalidade dessas se encontravam no estádio desovado (D). Fêmeas em maturação e maduras prevaleceram nos primeiros semestres. Os machos encontravam-se maduros o ano todo. Em maio de 2003, a amostra foi obtida do arrastão de praia, onde ocorreram exemplares imaturos, confirmando a seletividade da arte de linha de mão.

Em São Paulo, principalmente nos primeiros meses do ano (Verão), observouse alta incidência de exemplares maduros apresentando desova iminente $(\mathrm{C}, \mathrm{C} / \mathrm{H})$, aumentando a proporção de imaturos, em maturação e desovados nos meses de Outono e Inverno. Nos meses referentes ao segundo semestre, as fêmeas apresentaram-se desovadas e em maturação. A alta ocorrência de imaturos nos meses de março e abril, freqüentes no período, segundo os pescadores, correspondeu às amostras de indivíduos jovens que, acidentalmente, não foram descartados ao mar, sendo coletados na esteira de triagem durante a descarga.

Em Santa Catarina foi observada a ocorrência de fêmeas em maturação no primeiro semestre, prevalecendo desovadas no segundo. Aquelas em desova iminente $(\mathrm{C} / \mathrm{H})$, observadas no mês de maio de 2002, corresponderam à amostra proveniente da pesca de arrasto com parelhas. No segundo semestre predominaram os estádios de pósdesova, tanto em machos quanto em fêmeas.

Nas figuras 64 a 69 estão apresentadas as análises quantitativas do período de desova da espécie. Tanto as relações gonadossomáticas (RGS) quanto os índices gonadais (IG) e fatores de condição (K e K') médios mostraram maior relevância das gônadas de fêmeas durante os primeiros semestres dos anos analisados, apresentando picos de atividade reprodutiva no verão e fim do outono/início do inverno, principalmente em São Paulo. Para os machos, de maneira geral, a acuidade das análises é prejudicada, haja vista a pequena variação no peso gonadal dentro e fora do período reprodutivo.

No Rio de Janeiro, os valores médios mensais de RGS não ultrapassaram 3\%, não sendo observadas variações entre $R_{G} S_{1}$ e $R_{G S}$. Em São Paulo foram obtidas as 
maiores médias para fêmeas, ultrapassando 5\%. Em Santa Catarina, foram verificados os menores valores de RGS, excetuando-se o mês de maio/02 para fêmeas, amostra proveniente da pesca de parelhas, e março/02 para machos. A maior variação entre $\mathrm{RGS}_{1}$ e RGS 2 foi observada nas fêmeas capturadas em São Paulo, no verão e princípio do inverno, indicando maior alocação de energia para as gônadas nessa região. Nos demais Estados, pequena variação entre os RGS foi verificada, mostrando baixa relevância das gônadas em relação ao peso total do exemplar.

Os maiores valores médios mensais de $\mathrm{K}$ e $\mathrm{K}$ ' foram observados em Santa Catarina, indicando melhor grau de higidez dos exemplares de T. lepturus na região. Já a maior variação entre os valores mensais médios de $\mathrm{K}$ e $\mathrm{K}^{\prime}$ foi observada em São Paulo, onde maior alocação de energia para a hidratação das gônadas das fêmeas foi verificada. No Rio de Janeiro foram obtidos os menores valores, que indica menor "bem estar" dos exemplares, possivelmente relacionado ao estado de recuperação gonadal.

A variação mensal das medianas obtidas para o índice gonadal (IG) corroborou com aquela verificada para os demais índices. A amplitude dos valores variou consideravelmente nos diferentes Estados. Em São Paulo foi verificada a maior amplitude, pois as amostras incluíam além de exemplares adultos, muitos de pequeno porte. No Rio de Janeiro, devido a amostra apresentar somente exemplares de maior porte (seletividade da arte de pesca), foram verificadas as maiores medianas mensais de IG, excetuando-se a amostra de maio/03, quando foram utilizados exemplares de menor porte provenientes do arrastão de praia. A baixa freqüência de fêmeas hidratadas em Santa Catarina resultou nos menores valores do IG, com exceção de maio/02, quando a amostra de parelhas (defeso da tainha) apresentou fêmeas hidratadas em grande quantidade.

Utilizando-se a freqüência relativa (\%) de adultos por classe de comprimento total e anal, obteve-se os valores médios de comprimento de primeira maturação gonadal $\left(\mathrm{L}_{50}\right)$ para cada sexo e agrupados, apresentados na tabela 18. As comparações por razão de verossimilhança máxima indicaram que as fêmeas de Santa Catarina diferiram dos demais Estados. A ausência de exemplares nas classes de comprimento menores que $600 \mathrm{~mm}$ nas amostras do Rio de Janeiro, portanto jovens, podem ter influenciado na determinação do ponto de inflexão da curva $\left(\mathrm{L}_{50}\right)$, causando maior dispersão dos dados nesse. Este fato pode ter influenciando nos resultados comparativos (Figura 70). 
Através das distribuições de freqüência do diâmetro dos ovócitos das gônadas analisadas (Figuras 71), evidenciou-se a presença de dois lotes de ovócitos no interior das gônadas maduras e/ou hidratadas: o lote de estoque de reserva, com diâmetros entre 0,1 e 0,5 mm; e o lote dos ovócitos em desenvolvimento sincrônico que serão eliminados no próximo período de desova. O desenvolvimento ovocitário parece ocorrer em pequeno intervalo de tempo, dentro do amplo período de desova observado, pois amostras em meses adjacentes apresentaram ovócitos com diâmetros bem maiores. Dessa forma, Trichiurus lepturus parece apresentar desova parcelada, com pelo menos dois lotes de ovócitos eliminados por período de desova.

Em Santa Catarina, as gônadas apresentaram diâmetros de ovócitos menores que aquelas obtidas em São Paulo. Provavelmente, estas últimas se encontravam em período de desova iminente.

A contagem de ovócitos maduros e/ou hidratados de 36 exemplares de fêmeas maduras capturadas em São Paulo, apresentou fecundidades variando de 11.500 ovócitos para um exemplar de $840 \mathrm{~mm}$ de comprimento total e peso $380 \mathrm{~g}$, até 102.000 ovócitos para um exemplar de $1373 \mathrm{~mm}$ e peso $1595 \mathrm{~g}$. Para onze exemplares de fêmeas maduras capturadas em Porto Belo (SC), a fecundidade variou de 22.145 ovócitos para um exemplar de $1014 \mathrm{~mm}$ e $695 \mathrm{~g}$, até 80.519 ovócitos para um exemplar de $1187 \mathrm{~mm}$ e $1590 \mathrm{~g}$. As equações e curvas obtidas para as relações entre fecundidade e as variáveis de comprimento total e peso estão apresentadas na figura 72. A razão de verossimilhança máxima (Tabela 20) não evidenciou diferença significativa entre as relações de fecundidade com as variáveis de comprimento total e peso total, devido a ampla dispersão dos dados.

\section{Crescimento}

Foram analisados os pares de otólitos de 424 exemplares de T. lepturus para o estudo do crescimento, abrangendo as classes de 150 a $1550 \mathrm{~mm}$ de comprimento total, sendo 111 do Rio de Janeiro, 156 de São Paulo e 157 de Santa Catarina. O número de exemplares por sexo e classes de comprimento estão apresentados nas tabelas 21 a 23.

A descrição das amostras de comprimento, altura (Figura 73) e peso dos otólitos direito e esquerdo de cada exemplar por sexo e região estão apresentadas nas tabelas 24 a 26. Os testes estatísticos (teste $t$ e teste de Wilcoxon-Mann-Whitney, pareados) indicaram diferenças significativas entre os otólitos direito e esquerdo, 
principalmente em relação à altura dos mesmos, tanto nos machos como nas fêmeas (Tabela 27). Assim sendo, as análises restringiram-se aos otólitos esquerdos dos exemplares.

Alta correlação foi verificada entre as variáveis de comprimento, altura e peso dos otólitos e o comprimento total de T. lepturus, como esperado para variáveis biométricas podendo, portanto serem usados satisfatoriamente para o estudo do crescimento da espécie. Os parâmetros obtidos para as relações lineares entre comprimento do otólito e comprimento total do peixe, em cada Estado por sexo, estão apresentados na tabela 28. Na análise de covariância (ANCOVA), comparando-se as inclinações (b) e interceptos (a) entre sexos de cada Estado (Tabela 29), apenas no Rio de Janeiro não foi observada diferença significativa entre fêmeas e machos. Entre Estados, somente entre as fêmeas do Rio de Janeiro e Santa Catarina foram verificadas diferenças significativas. Os machos do Rio de Janeiro diferiram significativamente dos demais Estados.

As relações lineares entre altura do otólito e comprimento total dos exemplares (Tabela 30) diferiram entre os sexos em todos os Estados analisados. As retas obtidas para fêmeas e machos do Rio de Janeiro diferiram dos demais. Fêmeas e machos de São Paulo e Santa Catarina não apresentaram diferenças significativas entre os parâmetros dessas relações (Tabela 31).

Os parâmetros das relações entre peso do otólito e comprimento estão apresentados na tabela 32. A razão de verossimilhança máxima indicou coincidência entre as curvas de fêmeas e machos apenas em Santa Catarina. Entre Estados, as fêmeas de Santa Catarina e os machos do Rio de Janeiro diferiram dos demais (Tabela 33).

Os otólitos seccionados transversalmente (direção referente à altura dos mesmos) apresentaram núcleo opaco próximo ao sulcus acusticus (Figura 74), circundado por um padrão de bandas largas, translúcidas, e finas, opacas. A contagem e mensuração dos anéis de crescimento foram realizadas no sentido do núcleo até a extremidade dorsal do otólito.

Foram observados até sete anéis de crescimento nas secções de otólitos para ambos os sexos de T. lepturus, ocorrendo apenas um exemplar fêmea com oito anéis em Santa Catarina. No Rio de Janeiro não foram encontrados exemplares com 0 anel, devido à seletividade da arte de pesca de linha-de-mão (Tabela 34). A figura 75 apresenta os gráficos de densidade tipo "boxplot" dos raios de cada anel mensurado, verificando-se aumento crescente dos raios dos anéis com o aumento do número de 
anéis. A constância na formação dos mesmos em indivíduos com números diferentes de anéis pode ser observada na figura 76 , exceto a partir do anel 5 , devido ao pequeno número de exemplares com número maior de anéis.

$\mathrm{Na}$ análise das proporções bimestrais de bordas opacas e translúcidas, verificou-se periodicidade anual na formação dos anéis, com picos de proporção de anel opaco em meados do ano (Figura 77). A análise de incremento marginal corroborou esta periodicidade, confirmando a época de deposição dos mesmos (Figura 78). Assim sendo, o número de anéis verificado nos otólitos de T. lepturus refletirá a idade dos exemplares.

Para obtenção dos comprimentos retrocalculados em idades anteriores à captura, foram testados os modelos linear, potencial e logístico para verificação daquele que melhor representaria a relação entre o comprimento total dos exemplares e o raio total dos otólitos. As tabelas 35 a 37 apresentam a descrição dos resíduos de cada modelo, por sexo em cada Estado analisado. Optou-se pelo modelo logístico, cujos resíduos apresentaram menores valores de simetria e curtose estandartizadas, indicando melhor ajuste dos dados. Os parâmetros das curvas estimados para o modelo logístico, bem como seus desvios padrão e coeficientes de determinação, por sexo e agrupados, estão apresentados na tabela 38. As figuras 79 a 81 apresentam as curvas ajustadas aos dados por sexo em cada Estado, e seus respectivos diagramas de dispersão de resíduos.

O modelo de crescimento de von Bertalanffy foi ajustado aos diversos conjuntos de dados de comprimento total por idade, por sexo e agrupados. Os comprimentos médios por idade obtidos na leitura de anéis de crescimento dos otólitos (OtolMed) e os comprimentos médios retrocalculados (RetroMed) de fêmeas, machos e agrupados de cada Estado estão apresentados nas tabelas 39 a 41. As tabelas 42 a 44 apresentam os estimadores dos parâmetros da equação de crescimento obtidos para cada conjunto de dados analisado (OtolTot, Otolméd, RetroTot e RetroMed), bem como seus desvios padrão, coeficientes de determinação, índices de performance de crescimento $\left(\phi^{\prime}\right)$ e peso assintótico. Os índices de performance de crescimento apresentaram pequenas variações entre si, indicando coerência entre os parâmetros obtidos. Uma vez disponíveis os dados individuais, optou-se pela análise dos conjuntos OtolTot e RetroTot ao invés de suas médias por idade. As curvas de crescimento por sexo desses dois conjuntos foram significativamente diferentes quando testadas pelo método de razão de verossimilhança máxima (Tabela 45), principalmente em relação às hipóteses de igualdade entre $\mathrm{L}_{\mathrm{oo}}-\mathrm{k}$ e $\mathrm{k}-\mathrm{t}_{0}$. 
Nas análises subseqüentes, utilizou-se os estimadores dos parâmetros de crescimento obtidos para o conjunto OtolTot (Figuras 82 a 84). Comparando-se as curvas obtidas por sexo em cada Estado, verificaram-se curvas coincidentes para fêmeas e machos apenas em Santa Catarina. Não foram observadas diferenças significativas entre as curvas de crescimento obtidas para fêmeas nos diversos Estados. A curva obtida para os machos de São Paulo foi significativamente diferente dos demais Estados, porém apenas na hipótese que avalia as variâncias de todos os parâmetros agrupados (hipótese de curvas coincidentes), não ocorrendo diferenças nas demais hipóteses. As curvas de crescimento dos dados agrupados não apresentaram diferenças significativas entre os Estados analisados (Tabelas 46 e 47).

As chaves idade-comprimento por sexos e agrupados de cada Estado, apresentadas nas tabelas 48 a 50, fornecem a composição etária relativa em cada classe de comprimento. As classes de comprimento intermediárias abrangeram maior amplitude de idades.

O Anexo I apresenta um diagrama sintetizando os resultados obtidos nas diferentes comparações efetuadas com dados de T. lepturus.

\section{Mortalidade}

Para estimar as taxas de mortalidade total $(Z)$ foram utilizados os estimadores dos parâmetros de crescimento do modelo de von Bertalanffy para sexos agrupados. No Rio de Janeiro, foram utilizadas apenas as capturas computadas nos dias de coleta de dados da pesca de linha-de-mão, pois não foi possível a obtenção de dados mensais da captura no período de estudo (Tabela 51). Em São Paulo, foram utilizados os dados de captura mensais da pesca de arrasto de fundo com parelhas do período, disponibilizados pelo Instituto de Pesca/ APTA/SAA/SP (Tabela 52). Para Santa Catarina, utilizaram-se as capturas mensais da espécie obtidas nos cercos flutuantes da Empresa Pioneira da Costa S/A, apresentados anteriormente na Tabela 04.

Para o Rio de Janeiro, o menor intervalo de confiança foi verificado na reta calculada com nove pontos do braço descendente da curva de captura de comprimentos convertidos em idade, obtendo-se as estimativas de 1,29/ano para a taxa de mortalidade total $(\mathrm{Z})$ e $27,6 \%$ de sobrevivência (S). O comprimento de primeira captura (Lc) foi estimado em $850,8 \mathrm{~mm}$ de comprimento total, e o comprimento total médio do capturado 
acima de Lc (Lmed) foi de 1150,3mm, sendo obtida a estimativa de 0,37/ano para a taxa de mortalidade total (Z) pelo método de Ssentongo \& Larkin, com sobrevivência (S) de $69,3 \%$.

Em São Paulo, o menor intervalo de confiança também foi verificado para a reta com nove pontos do braço descendente da curva de captura, estimando-se $Z=$ 0,86/ano e sobrevivência de 42,4\%. O Lc foi estimado em $830,5 \mathrm{~mm}$ e o Lmed, em 1119,3mm, com Z de Ssentongo \& Larkin estimado em 0,41/ano, com sobrevivência de $66,1 \%$

Para Santa Catarina, o método de curva de captura apresentou $Z=0,97 /$ ano, e sobrevivência de 37,9\%, para a reta calculada com 13 pontos. Estimou-se para Lc o valor de 582,8mm, e para Lmed o valor de 964,4mm. O método de Ssentongo \& Larkin estimou $Z=0,44 /$ ano e $S=64,5 \%$.

Estes valores e os respectivos intervalos de confiança obtidos para as retas de curva de captura estão apresentados na tabela 53. A figura 85 apresenta as curvas de captura linearizadas para cada Estado. A idade relativa na qual a espécie passou a ser totalmente explotada foi menor na pesca de cerco flutuante (SC) e maior na pesca de linha-de-mão $(\mathrm{RJ})$. As inclinações das retas $(-\mathrm{b}=\mathrm{Z})$ do braço descendente das curvas de captura apresentaram diferenças significativas entre os Estados na análise de covariância (ANCOVA: $\mathrm{P}<<0,001$ ), sendo a reta calculada para o Rio de Janeiro diferente das demais pelo método de comparações múltiplas tipo Tukey $(\mathrm{P}<0,001)$. As retas de São Paulo e Santa Catarina apresentaram inclinações semelhantes $(P>0,5)$.

As estimativas das taxas de mortalidade natural (M) pelos diversos métodos propostos e dos respectivos parâmetros utilizados para o cálculo estão apresentados na tabela 54 (A e B). Os valores obtidos nos diversos métodos foram aproximados, excetuando-se aquele obtido pelo método de Rikhter \& Efanov, descartado por apresentar estimativas discrepantes das demais. Optou-se pela utilização da taxa de mortalidade natural obtida pelo método de Pauly para as análises subseqüentes.

As taxas de mortalidade por pesca e de explotação obtidas para T. lepturus nos diversos Estados analisados estão apresentadas na tabela 55. Considerando-se as taxas de mortalidade total $(Z)$ obtidas pelo método de curva de captura, a espécie vem sendo altamente explotada no Rio de Janeiro, muito além do rendimento sustentável otimizado, onde as taxas de mortalidade por pesca e natural seriam equivalentes $(\mathrm{E}=$ $0,5)$, apresentando níveis de mortalidade por pesca cinco vezes maior que a mortalidade natural. Porém, os dados de captura utilizados para a estimativa de $\mathrm{Z}$ foram muito 
falhos, além de menor amplitude de idade para as estimativas de parâmetros de crescimento, podendo ter sido superestimada. Taxas de mortalidade por pesca duas vezes maiores que as de mortalidade natural foram obtidas em São Paulo e Santa Catarina, valores altos, porém mais coerentes, indicando também alta explotação da espécie. As baixas estimativas de mortalidade por pesca verificadas para $\mathrm{Z}$ de Ssentongo \& Larkin indicam que a espécie estaria subexplotada.

\section{Rendimento e Biomassa Relativos por Recruta}

As curvas do modelo de rendimento relativo por recruta e de biomassa relativa obtidas para cada Estado estão apresentadas nas figuras 86 a 88. Os pontos de referência biológica de T. lepturus, $\mathrm{F}_{\max }$ e $\mathrm{F}_{0.1}, \mathrm{E}_{\max }$ e $\mathrm{E}_{0.1}$ estão apresentados na tabela 56 .

Os valores de rendimento máximo sustentável foram atingidos a baixas taxas de mortalidade por pesca, feição característica para espécies com baixa taxa de mortalidade natural.

Relacionando-se as taxas de explotação (E) e de mortalidade por pesca (F) obtidas acima com os pontos de referência biológica, observa-se que, pelo método de curva de captura, as taxas de explotação resultantes excedem (RJ e SC) ou aproximamse (SP) das respectivas taxas de explotação máxima, o mesmo ocorrendo para as taxas de mortalidade por pesca. Para o método de Ssentongo \& Larkin, tais taxas não ultrapassam nem ao menos as taxas a $10 \%\left(\mathrm{E}_{0.1}\right.$ e $\left.\mathrm{F}_{0.1}\right)$. 


\section{DISCUSSÃO}

A expansão e os a diversificação das atividades do homem na Terra tornaram extremamente importante e inadiável a correta administração dos recursos naturais de nosso planeta. Entendem-se como recursos naturais todos os produtos utilizados pelo homem e por ele extraídos diretamente dos estoques naturais, sem intervenção direta em sua produção. Os recursos naturais vivos têm a capacidade de se reproduzir. Dessa forma, se a atividade extrativa se mantiver dentro de certos limites, a parcela extraída será reposta através da reprodução e crescimento dos indivíduos restantes. Por isso recebem a denominação de recursos renováveis. Assim as populações de peixes são capazes de propiciar um rendimento sustentável, onde o tamanho do estoque é definido pelas condições ambientais, pelas características biológicas da espécie, e pela intensidade de pesca. Os dois primeiros não são passíveis de controle pelo homem; já a intensidade de pesca é resultante da atividade humana, em função do benefício econômico e social que se obtém da explotação dos recursos pesqueiros e, portanto, passível de controle (Castro, 1998).

As características oceanográficas de produção das águas tropicais brasileiras determinam a elevada biodiversidade faunística e a pequena densidade dos estoques pesqueiros aí presentes, explicando, em parte, a concentração do esforço de pesca sobre poucas espécies, que em termos de concentração e potencial, suportam uma atividade econômica rentável (Cergole et al., 2005). Dessa forma, devido ao caráter multiespecífico das principais pescarias comerciais, a produção de muitas espécies é subestimada, sendo englobadas na categoria "mistura" ou descartadas por apresentarem baixo interesse comercial. Enormes quantidades de peixes são descartadas no mar, sendo estimada em cerca de 1/3 da produção mundial pela FAO em 1994 (Matssura, 2001). Com a queda da produção das espécies-alvo das pescarias, a pesca tende progressivamente a desviar sua atenção para espécies menos valiosas, porém com potencial de captura (Hilborn \& Walters, 1992). Um exemplo deste fato é relatado por Castro (2000), com relação ao peixe-porco (Balistes capriscus), espécie que se tornou alvo das pescarias de arrasto de fundo com parelhas de São Paulo, a partir da queda na produção de pescada-foguete (Macrodon ancylodon). Outro exemplo pode ser verificado em Azevedo (2004), na pesca artesanal da região de Arraial do Cabo (RJ), onde a enchova (Pomatomus saltatrix) vem sendo substituída nos últimos cinco anos pelo espada (Trichiurus lepturus). 
As estatísticas de produção de pescado são também afetadas pela pequena quantidade de informações provenientes da pesca artesanal costeira. As pescarias próximas da costa são de grande importância para a economia local de muitos países desenvolvidos, como o Japão, e em desenvolvimento, como o Brasil, a partir das quais as pessoas de baixo poder aquisitivo não apenas adquirem seu próprio alimento, como também vendem o excedente para gerar alguma renda, operando em águas costeiras rasas, vistas como inacessíveis ou não-rentáveis pela frota comercial (Masumoto, 2003). Desenvolvida ao longo de toda a costa, torna-se um grande desafio o monitoramento dessa pescaria pelos órgãos públicos responsáveis pelo manejo e tomada de decisões por meio de ações regulatórias que promovam o bem estar econômico e social de todos os envolvidos no setor pesqueiro. Como comentado por Mendonça (1998), decisões no âmbito administrativo e de ordenamento pesqueiro tornam-se ineficientes e errôneas haja vista a desorganização da estatística pesqueira (quando existente) no Brasil, sem um sistema de coleta de dados eficiente.

O espada, Trichiurus lepturus, tem ampla distribuição, desde áreas estuarinas até profundidades de $120 \mathrm{~m}$, sendo capturado por quase todas as modalidades de pesca desenvolvidas na região sudeste-sul do Brasil, incluindo a pesca artesanal e esportiva, sendo pouco avaliado em termos de produção por não ser considerado espécie-alvo das pescarias. Nos relatórios de estatística pesqueira do IBAMA (2003, 2004), o espada aparece com irrisórias capturas na costa do Estado do Rio Grande do Sul. Entretanto, Haimovici \& Palácios (1981) apresentavam a espécie como a $5^{\text {a }}$ mais abundante na pesca de arrasto de fundo da região, sendo totalmente descartada pela pesca comercial na região sul, em prol de outras espécies de maior valor comercial.

Em São Paulo, há pouco menos de uma década, o espada era comercializado na categoria "mistura", tomando paulatinamente seu lugar como categoria de pescado. Nos dados de estatística pesqueira disponibilizados pelo Instituto de Pesca/APTA/SAA/SP, verificou-se pequeno número de desembarques apresentando a espécie no ano de 1998, ou por ainda estar incluída na categoria "mistura" ou por motivo de falta de pessoal envolvido nos trabalhos de coleta de dados. Durante o ano de 2002, foram acompanhados por esta autora, 17 desembarques da parelha Cigano do Mar III e IV $(16.750 \mathrm{~kg})$, e relatados apenas 5 desembarques $(9.500 \mathrm{~kg})$ da mesma parelha nos dados estatísticos daquele ano.

Com relação à pesca artesanal, apenas dados de linha-de-mão efetuados na região de Ubatuba (SP) foram computados. Seckendorf et al. (2000) realizaram uma 
análise das capturas de rede de cerco flutuante localizados no litoral norte de São Paulo, nos anos de 1997 e 1998, onde apresentam dados comparativos provenientes da Fundação Pró-Tamar e do serviço de controle da produção pesqueira marítima do Instituto de Pesca. A produção de espada controlada diariamente pela Fundação PróTamar foi estimada em 52 t no período, enquanto que os dados oficiais computavam apenas $11 \mathrm{t}$. Os autores concluem que se os dados reais fossem registrados oficialmente, a produção das principais espécies aumentaria em 25\% no ano de 1997, e em $87 \%$ em 1998, enfatizando a necessidade do controle da pesca definida como artesanal. Haimovici (1997), analisando a pesca artesanal da região sul do Brasil, considera que a pesca artesanal esteja subestimada em pelo menos $25 \%$ dos totais capturados. Outro fator a ser considerado é que T. lepturus é muito visado na pesca denominada recreativa, desenvolvida por pescadores amadores ao longo de toda a costa, e da qual não se tem a menor idéia de produção.

Dessa forma, verifica-se que a deficiência de dados de captura, apesar dos esforços aplicados pelas equipes dos órgãos governamentais, implicaria em conclusões errôneas para qualquer tipo de avaliação de estoque que se pretendesse desenvolver para o espada. Entretanto, mesmo utilizando-se os dados incompletos ou pontuais obtidos neste estudo, verificou-se aumento nas capturas da espécie em termos comerciais, que pode estar refletindo o decréscimo na captura de outras espécies de maior valor comercial com o conseqüente aumento no interesse por outras, com potencial de captura. $\mathrm{Na}$ pesca artesanal, pouco considerada até então, o espada é fortemente explotado em toda a região de estudo, podendo ser considerada espécie-alvo.

Com relação ao estrato da população explotado por cada arte de pesca aqui analisada, verificou-se que a pesca de arrasto de fundo com parelhas, desenvolvida no Estado de São Paulo, apresentou maior ocorrência de juvenis em suas capturas. Apesar do número de juvenis registrado no período de estudo ser pequeno, estes se referiam apenas aos acidentalmente mantidos a bordo, pois o restante era "descartado ao mar para não ocuparem lugar nos porões", segundo palavras textuais dos Mestres das parelhas. Em Santa Catarina, na pesca de cerco flutuante, verificou-se que os poucos juvenis coletados eram realmente acidentais, não havendo descarte nessa arte de pesca. No Rio de Janeiro, a pesca com linha-de-mão não afetou exemplares juvenis devido ao tamanho do anzol impossibilitar sua captura. Castro (2000) relata a grande quantidade de exemplares juvenis capturados pela pesca de parelhas na região de São Paulo que são classificados como "mistura" ou simplesmente descartados ao mar. 
O habitat ótimo para uma espécie é o local onde o animal pode otimizar seu tempo de vida e de sua prole. A seleção de um habitat é, portanto uma importante função comportamental para peixes adultos, especialmente no que se refere a alimentação, reação a predação e comportamento reprodutivo. Para muitas espécies de importância comercial, a seleção do habitat varia com estágios de sua vida, pois alimentação e desova freqüentemente tomam lugar em diferentes áreas. A maioria dos peixes pelágicos realiza migrações sazonais relacionadas à reprodução e alimentação (Fréon \& Misund, 1999). Esses padrões migratórios podem ser identificados na pesca pela variação das capturas por unidade de esforço (CPUE). Na pesca comercial de parelhas em São Paulo, as maiores capturas do espada ocorreram no primeiro semestre, englobando o período de verão-outono. Em Santa Catarina, as maiores capturas da rede de cerco flutuante junto à costa forma verificadas no inverno e princípio da primavera. Este comportamento, que será discutido posteriormente, fornece evidências de que a espécie desloca-se para regiões mais profundas no verão e outono para reprodução, ficando vulnerável à pesca de parelhas, retornando junto à costa no restante do ano para alimentação, sendo capturada pelas artes mais costeiras. A menor média de comprimentos observada nos exemplares coletados em Santa Catarina indica a utilização da área para crescimento e alimentação. Bellini (1980) relatou exemplares de pequeno porte (até $350 \mathrm{~mm}$ ) junto à costa o ano todo, e os de maior porte, apenas no inverno, estando dispersos em regiões mais profundas nas demais estações.

No sudeste e sul do Brasil, assim como em outras partes do mundo, muitos autores registraram a maior abundância da espécie no verão, em águas quentes e temperadas, próximas a frentes térmicas, estando entre os cinco peixes ósseos mais abundantes da região (Bellini, 1980; Sastry, 1984; Lazarus \& Sarma, 1991; GraçaLopes et al., 1993; Haimovici et al., 1994; Haimovici et al., 1996; Martins \& Haimovici, 1997). As condições oceanográficas, principalmente no que se referem aos gradientes de temperatura, são fatores limitantes na distribuição do espada. Martins (1992), verificou no sul do Brasil que águas a temperaturas inferiores a $11^{\circ} \mathrm{C}$ são limitantes na distribuição da espécie. Baik \& Park (1986), na costa da Coréia, evidenciaram correlação positiva entre a temperatura e a CPUE do espada, com período de pesca podendo ser previsto verificando-se as condições oceanográficas. Dekun \& Cungen (1987), na costa da China, verificaram também alta correlação da área central de ocorrência do espada com a curva isohalina de salinidade 34. 
Espécies de peixes com ampla distribuição geográfica podem estar divididas em populações mais ou menos isoladas reprodutivamente, os denominados estoques em terminologia pesqueira. Estoques individuais freqüentemente diferem significativamente em suas características biológicas, respondendo independentemente a explotação, requerendo independentes estratégias de manejo para garantir a manutenção de cada estoque da espécie a longo termo. A identificação desses estoques é, portanto essencial para o manejo e conservação das populações (Ferguson et al., 1995). Na biologia pesqueira, dentre os principais fatores para se definir um estoque é que os parâmetros de crescimento e mortalidade permaneçam constantes na área de distribuição de um estoque, podendo-se então definir estratégias de manejo (Sparre \& Venema, 1998).

A genética molecular tem sido uma importante ferramenta, fornecendo grandes contribuições nesse sentido. Várias técnicas são utilizadas para verificação da estruturação populacional com vistas à conservação e manejo dos recursos, sendo muitas vezes utilizadas em conjunto com técnicas tradicionais de diferenciação de estoques. A técnica de marcadores moleculares tipo RAPD (Randomly Amplified Polimorphic DNA) (Williams et al., 1990) gerou polêmica a princípio quanto à sua reprodutibilidade e precisão dos resultados em eletroforese (Silva \& Russo, 2000; Féral, 2002). Entretanto, mantidas as condições idênticas de amplificação e de corrida eletroforética, apresenta resultados satisfatórios em gel de agarose para fragmentos acima de 400pb (Dinesh et al., 1995).

Alguns trabalhos que relacionam diferentes técnicas de marcadores moleculares demonstram que marcadores RAPD apresentam resultados satisfatórios para avaliação da estrutura populacional. Apte et al. (2003), estudando a diversidade genética em populações cultivadas e naturais do molusco Perna canaliculus da Nova Zelândia, verificaram que tanto os marcadores RFLP (Restriction Fragment Lenght Polymorphism) como os RAPD identificavam diferenças significativas entre as populações estudadas. Smith et al. (1997) analisaram o peixe Hoplostethus atlanticus (Trachichthyidae) com três marcadores moleculares diferentes para avaliar a estrutura da espécie em quatro regiões da Nova Zelândia. Aloenzimas, RFLP e RAPD não mostraram diferenças entre duas populações do norte, mas diferenças significativas foram verificadas somente com aloenzimas e RAPD nas demais populações.

O gênero Trichiurus apresenta várias espécies habitando as águas dos mares da China, onde é intensamente explotado. A difícil identificação das diferentes espécies no 
capturado levou alguns pesquisadores da região a utilizarem ferramentas moleculares para diferenciação inter e intraespecíficas. Lee et al. (1993) compararam padrões eletroforéticos de isoenzimas de duas possíveis espécies do gênero Trichiurus, $T$. lepturus e T. japonicus, e verificaram alto grau de similaridade nos padrões analisados sugerindo que ambas pertençam à mesma espécie. Wang et al. (1994) desenvolveram estudos para identificação de espécies e populações do gênero utilizando isoenzimas e amostras morfológicas, definindo três diferentes espécies e oito populações na região. Meng et al. (2004) desenvolveram análises com marcadores moleculares RAPD e RFLP mitocondrial para analisar o polimorfismo intra e interespecífico de Trichiurus lepturus e Eupleurogrammus muticus, verificando baixa variabilidade intraespecífica e considerável divergência entre as espécies, confirmando a taxonomia das mesmas como pertencentes a diferentes gêneros.

A estrutura populacional do espada aqui observada com marcadores moleculares tipo RAPD, sugere que a espécie apresente dois grupos distintos ao longo da costa brasileira, delimitados possivelmente pelo delta do Rio Amazonas, que promove forte impacto na região costeira ao Norte do país (Brandini et al., 1997). As demais regiões não apresentaram indícios de estruturação, podendo haver fluxo gênico entre elas devido à influência da Corrente do Brasil atuante sobre a plataforma continental brasileira (Silveira et al., 2000), local de desova da espécie, que pode promover grande dispersão de ovos e larvas ao longo da costa leste. Em geral, espécies marinhas com fase larval longa estão sujeitas a maior dispersão, abrangendo maiores áreas de distribuição, e apresentam maior fluxo gênico com baixos níveis de diferenciação entre populações e maiores dentro das populações (Féral, 2002). Entretanto, a técnica aqui utilizada para diferenciação populacional pode não ter a sensibilidade necessária para detectar uma possível estruturação nessa região, sendo, portanto necessários estudos com outros marcadores moleculares mais sensíveis a diferenciações de baixa magnitude, tais como as técnicas de sequenciamento genético e microssatélites (seqüências de DNA com repetições curtas de 2 a 10 nucleotídeos), dentre outras.

Lima (2005), desenvolvendo estudos sobre a estruturação genética da corvina Micropogonias furnieri da costa brasileira, utilizou as técnicas de microssatélites, sequenciamento genético e polimorfismos de íntrons (seqüências não codificadoras de DNA). A autora detectou uma população muito diferenciada no Pará, além de outras três na região sudeste-sul do Brasil, a saber: uma no Rio de Janeiro, outra de São Paulo 
a Santa Catarina, e outra no Rio Grande do Sul, extendendo-se provavelmente até o Uruguai. A região de Torres foi demarcada como limítrofe das populações sudeste (SPSC) e sul, não sendo possível a identificação de limites entre as populações do sudeste (RJ) e sudeste (SP-SC) por ausência de amostras da região. Castro (1988), avaliando a diferenciação geográfica de caracteres merísticos e morfométricos da corvina na costa brasileira, verificou indícios de estruturação populacional em quatro grupos distintos, sendo o grupo de Belém (PA) e adjacências; grupo de São Luís (MA) e adjacências; grupo de Conceição da Barra (ES) e adjacências (incluindo Macaé, RJ); e o grupo de Santos (SP) e adjacências, corroborando os resultados de Lima (2005).

Santos et al. (2003) analisaram a estrutura populacional da pescada-foguete Macrodon ancylodon ao longo da costa brasileira utilizando a técnica de sequenciamento das porções $16 \mathrm{~S}$ e citocromo $\mathrm{b}$, regiões evolutivamente conservadas do DNA mitocondrial. Dois grupos geneticamente distintos foram verificados ocupando a costa brasileira, um deles ao norte, abrangendo de Pernambuco (BR) à Venezuela, denominado grupo tropical, e outro ao sul, abrangendo de São Paulo à Argentina, denominado grupo subtropical, com divergências genéticas de tal ordem que podem ser considerados pertencentes a diferentes espécies. Os autores sugerem que o padrão de correntes que atua na costa brasileira, Corrente do Norte do Brasil e Corrente do Brasil, funcione como barreira geográfica impedindo o fluxo gênico da espécie.

Galetti et al. (2006) apresentaram uma revisão dos trabalhos desenvolvidos para peixes de recifes (Pomacentridae, Pomacanthidae e Chaetodontidae) no Brasil que visam avaliar a diversidade genética dessas espécies baseando-se em estudos citogenéticos e marcadores moleculares. Os autores colocam que o estágio pelágico larval parece aumentar as oportunidades de dispersão das espécies a longas distâncias, intensificando seu fluxo gênico. Sugerem que o delta do Rio Amazonas, na região Norte, e as ressurgências, na região Sudeste do Brasil, sejam importantes barreiras oceanográficas que restrinjam a dispersão de larvas e ovos de diferentes espécies marinhas.

Mesmo estando disponíveis as mais arrojadas técnicas de análise de estruturação populacional, os estudos de características merísticas, morfométricas e fisiológicas, além da dinâmica populacional das espécies, têm sido ainda desenvolvidos no intuito de corroborar e até mesmo complementar a estruturação observada para as espécies. Maltagliati et al. (2003) estudaram Alphanius fasciatus, peixe estuarino do Mediterrâneo de duas localidades da costa da Sardenha, utilizando a técnica de RAPD e 
análises morfológicas do tamanho relativo das nadadeiras, característica relacionada à pressão de predação da espécie. Os autores verificaram diferenças significativas entre as populações em ambas análises, corroborando experimentos anteriores desenvolvidos com isoenzimas.

As comparações entre caracteres de T. lepturus efetuadas neste estudo, abrangeram a região entre Rio de Janeiro e Santa Catarina, porção da costa brasileira onde não foi evidenciada estruturação populacional com a técnica de RAPD. As variações observadas nessas comparações (Anexo I) parecem estar intimamente relacionadas às condições fisiológicas da espécie, no que diz respeito ao comportamento reprodutivo e seleção de habitats, que serão discutidos posteriormente. Dessa forma, a espécie utilizaria toda a região sudeste-sul do Brasil em resposta a sua estratégia de vida, justificando a grande "mistura" verificada pelas análises genético-populacionais na região.

A estratégia reprodutiva de uma espécie é o conjunto de característica que uma espécie deverá manifestar para ter sucesso na reprodução, de modo a garantir o equilíbrio da população. Considerando-se que cada espécie tem sua distribuição estabelecida por determinado conjunto de condições ecológicas, ela deve apresentar uma única estratégia reprodutiva e, para tanto, apresentar adaptações anatômicas, fisiológicas, comportamentais e energéticas específicas. Entretanto, as variações nas condições de determinado ambiente determinam mudanças em algumas características dessa estratégia, de modo que venha a ser bem sucedida. Essas características, variáveis, são as táticas reprodutivas. Assim, a estratégia reprodutiva é o padrão geral de reprodução mostrado por uma espécie ou população, enquanto as táticas reprodutivas são aquelas características variáveis no padrão, em resposta a flutuações do ambiente. Tanto a estratégia como as táticas são adaptativas (Wooton, 1989).

Exemplares de T. lepturus da costa sudeste-sul do Brasil, de Cabo Frio (RJ) a Torres (RS) foram analisados por Bellini (1980). As coletas sazonais foram realizadas em cruzeiros oceanográficos que abrangeram profundidades até $200 \mathrm{~m}$ com redes de arrasto de fundo. A espécie apresentou período de desova abrangendo o fím do verão ao início do inverno, com os menores exemplares ocorrendo no inverno e primavera. A proporção sexual sazonal não apresentou diferença significativa entre fêmeas e machos no período.

Martins \& Haimovici (2000) analisaram a reprodução de T. lepturus capturado sazonalmente no sul do Brasil, verificando período de maior atividade reprodutiva no 
fim da primavera e verão na plataforma e ao longo de todo o ano na quebra do talude. Os autores relacionam os estádios de maturação avançados com a ocorrência de altas temperaturas da superfície da água e estratificação moderada da coluna d'água. A proporção sexual variou com a estação do ano, ocorrendo maior número de machos na estação não reprodutiva, não havendo diferença significativa na estação reprodutiva.

Na região costeira da Índia, Tampi et al. (1968) analisaram exemplares de $T$. lepturus obtidos na estação de pesca que ocorria de julho a janeiro. Juvenis foram observados em junho-julho e dezembro-janeiro, e fêmeas maduras de abril a janeiro, com picos de atividade reprodutiva em abril-maio e dezembro-janeiro. Cortes histológicos de gônadas maduras apresentaram dois grupos de ovócitos, um grupo de menor diâmetro ao redor de $0,5 \mathrm{~mm}$, e outro de maior diâmetro, não ultrapassando $1,2 \mathrm{~mm}$, com características não totalmente hidratadas. A ausência de ovos nas coletas de plâncton na região corroborou com a idéia de que a espécie não desova naquela área.

Sheridan et al. (1984) analisaram T. lepturus capturado em cruzeiros oceanográficos na região norte do Golfo do México até profundidades de $91 \mathrm{~m}$. A época de reprodução foi avaliada pela ocorrência de fêmeas maduras e índices gonadosomáticos, sendo constatado longo período de desova, ocorrendo de abril a outubro, com pico no verão. Verificaram para toda região amostrada a proporção sexual de 1,64 machos:1 fêmea, e compararam tal proporção com resultados diferenciados de outros autores, onde a proporção de fêmeas era maior que a de machos e as áreas de coleta mais restritas à costa.

Kwok \& Ni (1999) analisaram duas espécies de espada provenientes de capturas comerciais nas águas costeiras de Hong Kong (Mar do Sul da China) - $T$. lepturus e T. nanhaiensis - espécies muito semelhantes que ocorrem na pesca da região. Para T. lepturus verificaram amplo período de atividade reprodutiva, abrangendo de fevereiro a outubro, com pico no verão (março a junho). A proporção sexual diferiu significativamente de 1:1 no período de desova, com fêmeas excedendo o número de machos em todas as classes de tamanho. Cortes histológicos apresentaram dois grupos de ovócitos de diâmetros diferentes, com os maiores atingindo 1,4mm.

Para avaliar o processo reprodutivo de T. lepturus, Munekiyo \& Kuwahara (1984a; 1984b) organizaram cruzeiros de pesquisa na Baía de Wakasa (Japão) realizando coletas de rede de cerco a profundidades entre 100 e $160 \mathrm{~m}$ (plataforma) e "long-line", entre 40 e 60m (junto à costa). Verificaram maior ocorrência de machos na plataforma e de fêmeas mais próximo à costa. Os grupos coletados na plataforma 
apresentavam estádios de maturação avançados e recém-desovados, e aqueles, junto à costa, apresentavam graus de maturação diversos, principalmente após a desova. Dessa forma, comprovaram sua hipótese inicial de que $T$. lepturus forma agregações de machos na plataforma e, na costa, agregam-se às fêmeas. Essas migram para a plataforma à medida que avançam seus estádios de maturação gonadal. Assim, a área de desova localizar-se-ia afastada da costa, com maior concentração de machos, pois as fêmeas, logo após a desova, retornam à costa, mas os machos permanecem na área de desova por mais tempo, dispersando-se após o período de reprodução. A proporção sexual dos grupos em área de desova, portanto, não é 1:1, sendo maior para machos, aumentando a probabilidade de fecundação. O período de desova verificado é longo, ocorrendo no verão e outono, podendo atingir até sete meses em algumas regiões.

Emlen \& Oring (1977) descrevem o sistema de acasalamento (“mating sistem") tipo "leq" para algumas espécies de insetos, sapos e aves, no qual se identifica a estratégia reprodutiva de T. lepturus. Nesse sistema, a atuação dos machos é constante. Em época de desova, os machos formam grupos e as fêmeas escolhem seus parceiros dentro do grupo. Não havendo coincidência de maturação entre as fêmeas, a desova se prolonga, de maneira que o grupo de machos mantém atividade sexual durante todo o período.

A estratégia reprodutiva do espada analisada neste trabalho apresenta grande semelhança com o descrito para a Baía de Wakasa, no Japão. Como nos trabalhos acima citados, um longo período reprodutivo foi observado para T. lepturus neste estudo, abrangendo os meses do primeiro semestre, principalmente no verão e princípio do inverno, com maior ocorrência de juvenis nesses períodos. O processo reprodutivo da espécie parece envolver as migrações descritas acima, englobando toda a área de estudo deste trabalho. Nas regiões mais costeiras, referentes às amostras de Rio de Janeiro e Santa Catarina, prevaleceram fêmeas em estádios de maturação gonadal desovado (D) ou em maturação (B), corroborado pelos menores valores dos índices reprodutivos utilizados. Os altos valores de fator de condição alométrico adicionados aos estádios de maturação sexual observados em Santa Catarina dão indícios que a região é utilizada para alimentação. Nas amostras de São Paulo a profundidades maiores, foram observados os maiores valores dos índices reprodutivos para ambos os sexos, bem como fêmeas apresentando desova iminente e machos maduros, indicando proximidade da área de desova. As diferentes proporções sexuais observadas em cada região levam a crer que fêmeas e machos segregam-se durante o processo reprodutivo, com 
concentração de fêmeas junto à costa e machos na plataforma, estes últimos em maior proporção no período e área de reprodução. A proporção de fêmeas, nos períodos de maior atividade reprodutiva, foi menor que a de machos, chegando a atingir 1 fêmea:4 machos no verão. As gônadas de fêmeas maduras (estádios $\mathrm{C}$ e $\mathrm{C} / \mathrm{H}$ ) apresentaram dois blocos de ovócitos com diferentes diâmetros. Fêmeas capturadas no mesmo mês apresentaram diferentes diâmetros de ovócitos no lote a ser eliminado na desova seguinte, podendo indicar que o período de maturação dos ovócitos não é coincidente entre elas. Nakatami et al. (1980) verificaram a ocorrência de ovos e larvas ao longo do ano em toda a plataforma de Cabo Frio (RJ) ao Cabo de Santa Marta Grande (SC), o que reforça o longo período de desova observado neste estudo, com maiores concentrações no outono a profundidades ao redor dos $100 \mathrm{~m}$, próximo à Ilha de São Sebastião, confirmando área e época de pico de desova aqui verificado.

As espécies pelágicas, que realizam processos migratórios, tendem a sincronizar seu período reprodutivo com as condições ambientais do meio, como processos de transporte horizontal, estratificação da coluna d'água e ocorrência de ressurgências costeiras, que podem acarretar a concentração da produção biológica evitando dispersão e beneficiar a sobrevivências das larvas por otimizar a busca por alimento (Bakun et al., 1983). Martins (1992) relacionou a desova de T. lepturus a condições de estratificação da coluna d'água em épocas do ano em que o transporte é dirigido para o oceano aberto, áreas menos produtivas para a alimentação das larvas. Entretanto, o autor salienta que ovócitos relativamente grandes, fecundidades relativamente baixas e a boa capacidade natatória das larvas, que segundo Munekiyo e Kuwahara (1986) eclodem com cerca de $6 \mathrm{~mm}$, indicam que a espécie investe mais na qualidade do que na quantidade de seus produtos reprodutivos, podendo ser considerada "k estrategista" quanto à reprodução. Cabe salientar que a produção de ovócitos relativamente grandes $(2,1 \mathrm{~mm})$ e sua liberação em áreas menos produtivas pode fazer parte de uma estratégia de proteção destes contra predação, já que as regiões mais rasas são amplamente dominadas por larvas e juvenis de várias espécies.

Campos et al. (2000), analisando dados hidrográficos do verão e inverno juntamente com modelagem numérica da região da quebra da plataforma da Baía de Santos, mostraram a ocorrência de ressurgência na área associada a meandros ciclônicos da corrente do Brasil, que desempenharia um importante papel no bombeamento de águas frias e ricas da ACAS (Água Central do Atlântico Sul) da região do talude para a plataforma continental. Neste período, quando foi verificada a maior atividade 
reprodutiva da espécie neste trabalho, este processo poderia estar produzindo a estratificação da coluna d'água e enriquecimento da região, propiciando $\mathrm{o}$ desenvolvimento das larvas de T. lepturus na costa sudeste do Brasil, como observado por Martins (1992) no sul.

Os comprimentos de primeira maturação sexual obtidos para T. lepturus neste trabalho foram semelhantes aos verificados na literatura. Para fêmeas, os comprimentos nos diferentes Estados variaram de 230 e $240 \mathrm{~mm}$ de comprimento anal $(650$ a $670 \mathrm{~mm}$ de comprimento total, com idades de 10 meses a 1 ano), e para machos, de 190 a $230 \mathrm{~mm}$ (530 a 650mm de comprimento total com idades de 9 a 10 meses). Bellini (1980) obteve comprimento médio de primeira maturação sexual muito inferior para a espécie $(390 \mathrm{~mm})$ na região sudeste e sul do Brasil. Entretanto, verifica-se a baixa ocorrência de exemplares de grande porte em suas amostras, predominando exemplares de 300 a $600 \mathrm{~mm}$, o que poderia causar desvios na determinação desse comprimento médio. Martins \& Haimovici (2000), no sul do Brasil, detectaram 693mm de comprimento total para fêmeas e $639 \mathrm{~mm}$ para machos. Magro (2000) obteve, para as fêmeas de espada da região sudeste-sul do Brasil, o comprimento médio de $605 \mathrm{~mm}$. Munekiyo \& Kuwahara (1988) verificaram no Japão, 220mm de comprimento anal para fêmeas e 210mm para machos (1 ano). Kwok \& Ni (1999), no Mar do Sul da China, obtiveram $255 \mathrm{~mm}$ de comprimento anal para fêmeas, correspondendo a 8,5 meses.

A fecundidade aqui obtida baseou-se na contagem do número de ovócitos do lote que apresentava maior diâmetro, e que, portanto seria eliminado na desova subseqüente. Entretanto, se o amadurecimento ovocitário do lote de menor diâmetro ocorrer em um ou dois meses, conforme proposto por Kwok \& Ni (op. cit.), tais ovócitos deveriam ser incluídos na estimativa de fecundidade por período reprodutivo. Maiores coeficientes de determinação foram obtidos nas relações entre fecundidade e peso total dos exemplares de espada neste estudo, o mesmo sendo verificado por Sheridan et al. (1984). Martins \& Haimovici (2000) e Munekiyo \& Kuwahara (1988), entretanto, obtiveram maior correlação entre fecundidade e comprimento dos exemplares. Utilizando-se a equação de fecundidade por comprimento total obtida por Martins \& Haimovici (op. cit.), obtiveram-se valores de fecundidade muito próximos aos verificados neste trabalho, através da contagem de ovócitos de fêmeas hidratadas coletadas em São Paulo.

A segregação espacial de machos e fêmeas adotada por T. lepturus como estratégia reprodutiva acarreta o desenvolvimento diferenciado dos exemplares, que 
habitam ambientes com diferenças oceanográficas marcantes, principalmente no que diz respeito à disponibilidade de alimento. A região costeira, onde a produtividade é maior devido ao aporte de nutrientes terrígenos, oferece às fêmeas melhores condições para seu crescimento e desenvolvimento, pois estas retornam à costa logo após a desova. Os machos, permanecendo longos períodos em águas mais profundas e menos produtivas, podem apresentar menor desempenho quanto a seu crescimento. Isto é evidenciado pelos menores valores de fator de condição alométrico em todos os Estados aqui analisados, também resultantes do longo período de alocação de energia para reprodução. As diferenças significativas observadas para o comprimento e a altura dos otólitos de fêmeas e machos podem ser outro reflexo dos efeitos causados pela estratégia adotada pela espécie.

O investimento extensivo dos machos no processo reprodutivo pode impedi-los de explorar regiões mais produtivas para sua alimentação. Martins (1992), analisando a atividade alimentar da espécie na região sul do Brasil, constatou que a intensidade alimentar das fêmeas dessa espécie foi significativamente menor no período reprodutivo. Os machos, por sua vez, não apresentaram variações na intensidade alimentar entre períodos reprodutivo e não reprodutivo, apresentando também os menores valores para o fator de condição alométrico.

A partir da idade de primeira maturação gonadal (cerca de um ano), o crescimento de machos e fêmeas foi diferenciado, fato este evidenciado pelos menores comprimentos médios de machos nas idades subseqüentes. Além disso, as fêmeas atingiram comprimentos e idades maiores que os machos. Munekiyo \& Kuwahara (1988a), analisando a espécie no mar do Japão, verificaram o mesmo crescimento diferenciado entre os sexos, mais acentuado em indivíduos com mais de dois anos, que correspondeu ao início do processo reprodutivo.

O crescimento dos otólitos do espada apresentou alta correlação com o crescimento corporal do peixe. A formação do anel opaco ocorreu uma vez ao ano, verificada no final do inverno-início da primavera, e coincide com o período de maior atividade alimentar da espécie, que ocorre após o período reprodutivo. Os raios de cada anel nas diferentes idades foram muito semelhantes nos diversos Estados analisados, não indicando variações no crescimento dessa estrutura na área de estudo. A idade máxima verificada para ambos os sexos de espada foi de sete anos, com apenas um exemplar fêmea em Santa Catarina com oito. 
Bellini (1980) verificou a formação anual dos anéis de espada da costa sudestesul do Brasil no mesmo período, verificando no máximo exemplares de cinco anos. Entretanto, suas amostras apresentaram poucos exemplares de grande porte. Magro \& Cergole (2000), analisando otólitos inteiros da espécie da região sudeste-sul do Brasil, observaram seis anéis de crescimento nos otólitos. Na análise do incremento marginal dos otólitos de espada do Mar Leste da China e do Mar Amarelo, Hamada (1971) verificou a formação dos anéis anuais entre dezembro e fevereiro, inverno e primavera naquele local, com idade máxima de cinco anos. Kwok \& Ni (2000), estudando o crescimento dos espadas do Mar do Sul da China, determinaram o mesmo período para formação dos anéis opacos da espécie, sugerindo que os mesmos se formavam em resposta à redução da temperatura da água e não ao pico de desova como proposto por outros autores por ele mencionados. A idade máxima verificada foi de seis anos, porém consideraram em suas análises indivíduos apenas até quatro anos, pois os exemplares mais velhos foram raros.

As estimativas dos parâmetros de crescimento do modelo de von Bertalanffy são comumente obtidas utilizando-se os valores médios por idade. Segundo Haddon (2001), não é recomendado que essas médias sejam utilizadas se os dados individuais estão disponíveis, pois podem não ser representativas da idade se os comprimentos individuais não seguirem uma distribuição normal. Portanto, optou-se pela utilização dos comprimentos individuais para cada idade.

Os comprimentos retrocalculados são freqüentemente utilizados para estimar os comprimentos em idades raramente observadas (Francis, 1990), principalmente no que diz respeito às idades iniciais, que muitas vezes estão ausentes na amostra devido a seletividade dos aparelhos de pesca utilizados. Apesar dos estimadores de parâmetros de crescimento com comprimentos retrocalculados terem apresentado aqui menores desvios padrão, foram utilizados estimadores obtidos na leitura de otólitos, não só por serem mais condizentes na maioria das amostras analisadas, mas também por incluírem os comprimentos na idade zero, abrangendo maior amplitude de dados.

Neste estudo foi observado que os machos atingem seu comprimento máximo mais rapidamente que as fêmeas, porém são menores que elas. Os comprimentos máximos assintóticos $\left(\mathrm{L}_{\mathrm{oo}}\right)$ variaram de 1740 a 2010mm $(783$ a $967 \mathrm{~mm}$ de comprimento anal) para fêmeas, e 1373 a 1580mm (583 a $712 \mathrm{~mm}$ de comprimento anal) para machos, com taxas de crescimento entre 0,12 e 0,18 /ano e 0,17 e $0,25 /$ ano, respectivamente. Os comprimentos máximos assintóticos verificados para fêmeas e machos no Rio de 
Janeiro foram muito diferentes daqueles observados nos demais Estados. Acredita-se que a ausência de exemplares com idade zero possa ter afetado a curvatura do modelo, superestimando o valor para as fêmeas e subestimando para machos. Simulações do modelo com a introdução de um valor estimado para a idade zero refletiram a importância desse ponto para uma estimativa mais coerente dos parâmetros de crescimento.

Bellini (1980), no sudeste e sul do Brasil, utilizando o método de FordWalford, obteve comprimento máximo assintótico $\left(\mathrm{L}_{\mathrm{oo}}\right)$ de $3397 \mathrm{~mm}$ e taxa de crescimento (k) de 0,024/ano. Hamada (1971), para o espada dos mares da China, obteve $\mathrm{L}_{\mathrm{oo}}$ de $766 \mathrm{~mm}$ de comprimento anal e $\mathrm{k}$ de 0,139/ano, pelo método de FordWalford, com comprimentos médios por idade obtidos da leitura de secções de otólitos e retrocalculados. Narasimham (1976), na Índia, utilizou o método de deslocamento de modas na distribuição de freqüência de comprimentos para estimar o comprimento médio nas idades ausentes na leitura de anéis em otólitos, obtendo $\mathrm{L}_{\mathrm{oo}}$ de $1450 \mathrm{~mm}$ de comprimento total e $\mathrm{k}$ de 0,29/ano. Hanabuchi (1989), para o espada dos mares do Japão, através da leitura de secções de otólitos e Ford-Walford, verificou $\mathrm{L}_{\mathrm{oo}}$ variando de 400 a $502 \mathrm{~mm}$ de comprimento anal, e k de 0,44 a 0,6/ano, para três grupos sazonais diferenciados pelo tamanho do primeiro anel de crescimento. Park et al. (1996), analisando anéis de crescimento de vértebras do espada dos mares da Coréia, obteve para fêmeas $\mathrm{L}_{\mathrm{oo}}$ de $50,5 \mathrm{~cm}$ de comprimento anal e k de 0,162/ano, e para machos, $\mathrm{L}_{\mathrm{oo}}$ de $32,4 \mathrm{~cm}$ e $\mathrm{k}$ de 0,336/ano. As diferentes metodologias utilizadas podem resultar em estimadores de parâmetros de crescimento diferentes, mas na maioria dos casos, as fêmeas sempre apresentam comprimentos maiores que os machos. O único trabalho disponível onde isso não foi verificado foi relatado por Kwok e Ni (2000), para os espadas no Mar do Sul da China. Os autores utilizaram um modelo de regressão linear múltipla para avaliar o crescimento baseando-se no comprimento do peixe e no peso do otólito para predizer a idade, obtendo para fêmeas o $\mathrm{L}_{\mathrm{oo}}$ de $601,4 \mathrm{~mm}$ de comprimento anal e $\mathrm{k}$ de 0,158 /ano, e para machos, $\mathrm{L}_{\mathrm{oo}}$ de $755 \mathrm{~mm}$ e $\mathrm{k}$ de $0,116 /$ ano. Os estimadores obtidos neste trabalho foram superiores à maioria dos acima citados, devido possivelmente às diferentes metodologias empregadas ou mesmo pelas diferentes condições ambientais existentes na região sudeste-sul do Brasil.

As diferentes metodologias utilizadas para o cálculo da taxa de mortalidade total $(Z)$ neste trabalho apresentaram valores muito discrepantes entre si. O método de curva de captura de comprimentos convertidos em idade apresentou valores de 0,86 e 
0,97/ano para os Estados de São Paulo e Santa Catarina, respectivamente. No Rio de Janeiro foi verificada a mais alta taxa de mortalidade total no valor de 1,29/ano, mas se for considerado que os estimadores de parâmetros de crescimento estejam incongruentes, como discutido acima, tal taxa pode estar superestimada. Para o método de Ssentongo \& Larkin, as taxas variaram de 0,37 a $0,44 /$ ano, muito inferiores às anteriores. As taxas de mortalidade natural (M) foram semelhantes para a maioria dos métodos utilizados, e pelo método empírico de Pauly (1980), variaram de 0,20 a 0,29/ano, considerando-se o desconto de $20 \%$ proposto pelo autor para peixes que formam cardumes. As taxas de mortalidade total verificadas na literatura foram iguais ou superiores às aqui observadas, com valores de mortalidade natural também superiores. Infelizmente, a maioria dos artigos disponíveis é escritos em japonês, chinês ou coreano, locais onde o espada é altamente explorado, e como não são facilmente disponíveis no Brasil, as informações foram obtidas somente através dos abstracts, que não apresentavam detalhes sobre as metodologias empregadas, não permitindo análises mais profundas.

Magro (2005), analisando exemplares de espada capturados em cruzeiros oceanográficos na costa sudeste-sul do Brasil, utilizou a subrotina ELEFAN I, do pacote computacional FISAT para obter as estimativas dos parâmetros de crescimento, obtendo Loo de 2450mm e k de 0,27/ano. A taxa de mortalidade total ( $Z$ ) do modelo de curva de captura de comprimentos convertidos em idades foi de 2,49/ano, com taxa de mortalidade natural, obtida pela equação empírica de Pauly, de 0,32/ano, com redução de $20 \%$ pela formação de cardumes. Somvanshi \& Joseph (1988), na Índia, obtiveram $\mathrm{Z}=2$, 16/ano e $\mathrm{M}=0$,8/ano para exemplares com $\mathrm{L}_{\mathrm{oo}}$ de $1090 \mathrm{~mm}$ e $\mathrm{k}=0,64$ /ano. Chakraborty (1990), também em águas indianas, obteve $Z=1,96 /$ ano e $M=1,05 /$ ano para espadas com $\mathrm{L}_{\mathrm{oo}}=1290 \mathrm{~mm}$ e $\mathrm{k}=0,50 /$ ano com idade máxima de três anos. Zhang (1997), em águas coreanas, obteve $Z=1,28 /$ ano e $M=0,44$ /ano para exemplares com $L_{o o}$ $=460 \mathrm{~mm}$ de comprimento anal e $\mathrm{k}=0,39 / \mathrm{ano}$. Os altos valores de $\mathrm{M}$ observados podem estar relacionados ao menor comprimento máximo e maiores taxas de crescimento verificados nessas regiões, considerando-se também que não consideraram o desconto de $20 \%$ para formação de cardumes, o que em alguns casos aproximariam tais estimativas dos valores aqui obtidos.

A resposta fornecida por modelos de rendimento por recruta $(\mathrm{Y} / \mathrm{R})$ é expressa em gramas por recruta por ano, e não tem direta aplicação no manejo pesqueiro. Para o manejo, o que interessa são as diferenças relativas do Y/R para diferentes valores de 
mortalidade por pesca (F). Os pescadores não estão interessados em "imaginar" o rendimento por recruta, e sim o quanto a pesca pode melhorar com a variação do esforço de pesca (Gayanilo \& Pauly, 1997). Tal informação pode ser obtida com o modelo de rendimento relativo por recruta $\left(Y^{\prime} / R\right)$ que requer menos estimativas de parâmetros para sua aplicação, que são a razão entre a taxa de mortalidade natural (M) e a taxa de crescimento $(\mathrm{k})$, e a razão comprimento de primeira captura (Lc) e comprimento máximo assintótico $\left(\mathrm{L}_{\mathrm{oo}}\right)$.

A aplicação deste modelo utilizando-se a taxa de mortalidade natural (M) com o modelo empírico de Pauly forneceu uma curva de $Y^{\prime} / R$ que remete às espécies de vida longa, já que a longevidade do espada foi ao redor de 14 anos. Com M relativamente baixo, o peixe pode crescer mais antes de ser capturado, devido ao ganho em biomassa decorrente do crescimento individual exceder as perdas causadas pela mortalidade natural para uma grande parte da vida das coortes. Dessa forma, a taxa de mortalidade no ponto de máximo rendimento (Fmax) deve ser relativamente baixa (Sparre \& Venema, 1999; Gayanilo \& Pauly, 1997), como verificado neste trabalho, variando de 0,34 a 0,61/ano. Esforços de pesca acima deste nível levam a uma rápida redução do estoque.

O único trabalho disponível na literatura que apresentava análises de rendimento por recruta para o espada foi o de Narasimham (1983), na Índia. O autor verificou que até $87 \%$ dos espadas capturados eram juvenis na idade 0 (zero), tornandose totalmente explotado ( $\mathrm{Lc}$ ) aos $20 \mathrm{~cm}$, com idade de primeira captura (Tc) de 0,3 anos, abaixo da idade de primeira maturação sexual. O comprimento máximo assintótico foi $\mathrm{L}_{\mathrm{oo}}=1450 \mathrm{~mm}$, com taxa de crescimento $\mathrm{k}=0,29 / \mathrm{ano}$, e idade máxima de 5 anos. Estimou $Z=1,2 /$ ano, pelo método de curva de captura, e $M=0,9 /$ ano, resultando numa taxa de mortalidade por pesca $\mathrm{F}=0,3$ /ano. $\mathrm{O}$ rendimento máximo sustentável obtido foi de $26 \mathrm{~g}$ por recruta, com taxa de mortalidade por pesca $\mathrm{F}_{\max }=0,6 /$ ano. Apesar da taxa de mortalidade por pesca observada estar abaixo do $F_{\max }$, o autor salienta que seria necessário o aumento do comprimento (e idade) de primeira captura, e simula o modelo para Tc de um ano, obtendo máximo rendimento máximo de $52 \mathrm{~g}$ com $\mathrm{F}_{\max }=0$, 8/ano.

Evidências empíricas indicam que devido às incertezas inerentes ao modelo de $\mathrm{Y} / \mathrm{R}$, a taxa de mortalidade por pesca máxima $\left(\mathrm{F}_{\max }\right)$ tende a ser muito alta e leva ao declínio dos estoques. A estratégia do ponto de referência limite, $F_{0.1}$, não tem justificativa teórica, mas empiricamente parece ser mais conservativa e garantir maior resiliência do estoque (Haddon, 2001). Hilborn \& Walters (1992) consideram a 
implementação desta estratégia de avaliação a mudança de paradigma mais importante na prática pesqueira desde a elaboração do conceito de rendimento máximo sustentável (MSY).

Dessa forma, assumindo-se o ponto de referência limite $\left(\mathrm{F}_{0.1}\right)$, as taxas de mortalidade por pesca $(\mathrm{F})$ obtidas para $\mathrm{Z}$ resultante das curvas de capturas estão muito acima dos limites observados no modelo de $\mathrm{Y}^{\prime} / \mathrm{R}$. Já aquelas obtidas com o Z do modelo de Ssentongo \& Larkin, ainda se encontram abaixo desses limites. Entretanto, cabe relembrar que, as capturas de espadas são subestimadas, e segundo os pescadores de todas as regiões analisadas, a espécie vem apresentando certo declínio em alguns períodos do ano, o que pode refletir um possível processo de sobrepesca em andamento. Outra informação proveniente da experiência dos pescadores é que o espada era "bem maior" antigamente do que o capturado atualmente, outro indício de sobrepesca. Dessa forma, apesar dos resultados aqui observados deverem ser avaliados com cautela, a taxa de mortalidade total obtida no modelo de curvas de captura com comprimentos convertidos em idade deve ser considerada mais realista para o quadro que se apresenta. 


\section{CONCLUSÃO}

Trichiurus lepturus é uma espécie demerso-pelágica que apresenta ampla distribuição geográfica, ocupando toda a plataforma continental, ficando exposta a diferentes artes de pesca. Na pesca comercial de arrasto de fundo com parelhas é capturada como fauna acompanhante de espécies demersais, como a corvina Micropogonias furnieri, a pescada-foguete Macrodon ancylodon, o goete Cynoscion jamaicensis e o peixe-porco Balistes capriscus, sendo por isso pouco avaliada em termos de produção pesqueira. Na pesca artesanal de linha-de-mão e cerco flutuante, o espada é um importante recurso pesqueiro, podendo ser classificado como espécie-alvo. As capturas apresentaram tendências crescentes de produção do espada no período, o que pode estar refletindo maior interesse pela espécie em vista da diminuição dos estoques das espécies-alvo. As oscilações verificadas na CPUE de T. lepturus ao longo do ano identificam seu comportamento migratório estreitamente relacionado à reprodução e alimentação.

Marcadores moleculares tipo RAPD identificaram a presença de uma população distinta de T. lepturus na região norte do Brasil, abrangendo a costa do Pará, possivelmente delimitada pela forte influência do delta do Rio Amazonas. A partir de Natal (RN) em direção ao sul, não foi verificada estruturação populacional da espécie. A grande capacidade migratória da espécie, áreas de desova em regiões mais profundas da plataforma, condições oceanográficas da região, dentre outros, podem ser fatores que contribuam para a dispersão de ovos e larvas por toda a região, ocorrendo fluxo genético por toda a costa leste do país. Entretanto, outras técnicas mais sensíveis de avaliação genética devem ser utilizadas para confirmação desses limites observados.

O espada apresentou amplo período de desova ocorrendo do verão ao início do inverno, com fêmeas apresentando desova parcelada e maturando em períodos não coincidentes. A estratégia reprodutiva da espécie envolve migrações que ocupam toda a área de estudo. As fêmeas, que se agregam junto à costa, migram para as áreas de desova localizadas na plataforma à medida que amadurecem sexualmente, onde se encontram com os machos, que lá se concentram. Após a desova, retornam à costa para alimentação. Os machos permanecem na área de desova aguardando outros grupos de fêmeas. A proporção sexual na área de desova, portanto, é maior para machos, que mantêm atividade sexual por todo o período reprodutivo. 
O comprimento médio de primeira maturação sexual variou de 647 a $670 \mathrm{~mm}$ de comprimento total para fêmeas, e de 526 a $650 \mathrm{~mm}$ para machos. A estimativa de fecundidade por lote variou de 11.500 ovócitos para um exemplar de $840 \mathrm{~mm}$ de comprimento total e peso $380 \mathrm{~g}$, até 102.000 ovócitos para um exemplar de $1373 \mathrm{~mm}$ e peso $1595 \mathrm{~g}$, com ovócitos maduros apresentando diâmetros superiores a 2,1mm.

A estratégia reprodutiva adotada pela espécie requer grande desgaste energético para os machos, que se evidencia nos menores comprimentos atingidos por eles em relação às fêmeas, após a primeira maturação sexual. As estimativas de comprimento total máximo assintótico $\left(\mathrm{L}_{\mathrm{oo}}\right)$ para fêmeas foram de 1740 a $2010 \mathrm{~mm}$ e para machos, de 1373 a $1580 \mathrm{~mm}$. As taxas de crescimento (k) para fêmeas e machos foram de 0,12 a 0,15/ano e de 0,17 a 0.25/ano, respectivamente, verificando-se que os machos atingem seu comprimento máximo mais rapidamente que as fêmeas. A idade máxima observada para a espécie foi de 8 anos, com longevidade calculada em cerca de 14 anos. A mortalidade natural da espécie variou de 0,2 a 0,29/ano.

As taxas de mortalidade total e por pesca obtidas indicam que a espécie vem sendo amplamente explotada, com valores próximos ou excedendo aos pontos limite de referência biológica $\left(\mathrm{F}_{\max }\right)$ obtidos na análise de rendimento relativo por recruta. Tais valores, porém devem ser avaliados com cautela. Os valores de produção da espécie são obviamente subestimados, pois não sendo alvo das pescarias, é freqüentemente descartada pela pesca de grande porte em prol de outras espécies de alto valor comercial. Dessa forma, o quadro que se apresenta é preocupante, podendo estar em andamento um processo de sobrepesca da espécie antes mesmo de se tornar alvo das pescarias. 


\section{BIBLIOGRAFIA}

Apte, S.; S. Bastiaan \& J. P. A. Gardner. 2003. A comparison of genetic diversity between cultured and wild populations, and a test for genetic introgression in the New Zealand greenshell mussel Perna canaliculus (Gmelin 1791). Aquaculture, 219:193-220.

Ávila-da-Silva, A.O., M. H. Carneiro \& L. Fagundes. 1999. Sistema Gerenciador de Banco de Dados de Controle Estatístico de Produção Pesqueira Marinha PROPESQ. In: Anais do XI CONGRESSO BRASILEIRO DE ENGENHARIA DE PESCA (CONBEP) / I CONGRESSO LATINO-AMERICANO DE ENGENHARIA DE PESCA (CONLAEP), 17-21 out., Recife, 1999. Associação dos Engenheiros de Pesca de Pernambuco \& Federação das Associações dos Engenheiros de Pesca do Brasil. 2:824-832.

Ávila-da-Silva, A. O. 2002. A evolução da pesca de linha-de-fundo e a dinâmica de população do peixe-batata, Lopholatilus villarii (Teleostei: Malacanthidae) na margem continental da costa brasileira entre os paralelos $22^{\circ}$ e $28^{\circ} \mathrm{S}$. Tese de doutorado. Universidade de São Paulo, Instituto Oceanográfico. 218p.

Azevedo, P. J. S. 2004. Onze anos de produção pesqueira no Município de Arraial do Cabo - RJ, Brasil. Dissertação de Mestrado. Universidade Federal Fluminense, Instituto de Biologia Marinha. 91p. + anexos.

Baik, C. J. \& J. H. Park. 1986. Relationship between oceanographic conditions and catch of the hairtail, Trichiurus lepturus Linnaeus from the stow net. Bull. Fish. Res. Dev. Agency, Pusan, 39:29-41.

Bartley, D. M. 2005. Status of the world's fishery genetic resources. International Workshop The role of biotechnologyfor tha characterisation and conservation of crop, forestry, animal and fishery genetic resources. Vila Gualino, Turin, Italy. 5-7 March, 2005.

Beddington, J. R.; A. A. Rosenberg; J. Á. Crombie \& G. P. Kirkwood. 1990. Stock assessment and the provision of management advice for the short-fin squid fishery in Falkland Islands waters. Fish. Res., 8:351-365.

Bellini, A. T. 1980. Biologia e bionomia de Trichiurus lepturus (Linnaeus, 1758) (Trichiuridae, Perciformes, Teleostei), da costa brasileira, entre Cabo Frio (23o00'S) e Torres (29o21'S). Dissertação de mestrado. Universidade de São Paulo, Instituto Oceanográfico. 97p.

Bielawski, J. P. \& D. E. PUMO. 1997. Randomly amplified polymorphic DNA (RAPD) analysis of Atlantic coast striped bass. Heredity, 78:32-40.

Biseau, A. 1998. Definition of a directed fishing effort in a mixed-species trawl fishery, and its impacts on stock assessments. Aquat. Living Resour. 11(3):119-136. 
Brandini, F. P., R. M. Lopes, K. S. Gutseit, H. L. Spach \& R. Sassi. 1997. Planctonologia na Plataforma Continental do Brasil: Diagnose e Revisão Bibliográfica. Avaliação do Potencial Sustentável de Recursos Vivos da Zona Econômica Exclusiva- REVIZEE, Rio de Janeiro, 96 pp.

Caddy, J. F. \& G. D. Sharp. 1986. Na ecological framework for marine fishery investigations. FAO Fish. Tech. Pap., 283: 152p.

Campos, E. J. D.; D. Velhote \& I. C. A. da Silveira. 2000. Shelf break upwelling driven by Brazil Current cyclonic meanders. Geophysical Res. Letters, 27(6):751-754.

Castro, L. A. B. de. 1998. Aplicação do modelo "Beam 4" à pesca de parelhas no sudeste do Brasil $\left(23^{\circ} \mathrm{S}\right.$ a $\left.29^{\circ} \mathrm{S}\right)$. Tese de doutorado. Universidade de São Paulo, Instituto Oceanográfico, 115 p. + anexos.

Castro, P. M. G. de. 1988. Diferenciação geográfica de Micropogonias furnieri (Desmarest, 1823) na costa brasileira entre as latitudes $2^{\circ} 00^{\prime} \mathrm{N}-2^{\circ} 30^{\prime} \mathrm{S}$ e $18^{\circ} \mathrm{S}-$ $25^{\circ}$ S. Dissertação de mestrado. Universidade de São Paulo, Instituto Oceanográfico. $224 \mathrm{p}$.

Castro, P. M. G. de. 2000. Estrutura e dinâmica da frota de parelhas do Estado de São Paulo e aspectos biológicos dos principais recursos pesqueiros demersais costeiros da região Sudeste/Sul do Brasil $\left(23^{\circ}-29^{\circ} \mathrm{S}\right)$. Tese de doutorado. Universidade de São Paulo, Instituto Oceanográfico, 122p.+tabs+figs.

Castro-Filho, B. M. \& L. B. Miranda. 1998. Physical Oceanography of Western Atlantic Continental Shelf Located Between $4^{\circ} \mathrm{N}$ and $34^{\circ} \mathrm{S}$ Coastal Segment (4,W). In Robinson, A. R. and Brink, K. H. (eds). The Sea. John Wiley \& Sons, 11: 209251.

Cergole, M. C.; A. O. Ávila-da-Silva \& C. L. D. B. Rossi-Wongtschowski (eds). 2005. Análise das principais pescarias comerciais da região sudeste-sul do Brasil: Dinâmica populacional das espécies em explotação. Série Documentos REVIZEE - Score Sul. São Paulo. Instituto Oceanográfico - USP. 176p.

Cergole, M.C. \& H. Valentini. 1994. Growth and mortality estimates of Sardinella brasiliensis in the southeastern Brazilian Bight. Bolm. Inst. oceanogr., S. Paulo, 42(1/2):113-127.

Cerrato, R. M. 1990. Interpretable statistical tests for growth comparison using parameters in the von Bertalanffy equation. Can. J. Aquat. Sci., 47:1416-1426.

Chakraborty, S. K. 1990. Fishery, age, growth and mortality estimates of Trichiurus lepturus Linnaeus from Bombay waters. Indian J. Fish., 37(1):1-7.

Clark, A. G. \& Lanigan, C. M. S. 1993. Prospects for estimating nucleotide divergence with RAPDs. Mol. Biol. Evol. 10:1096-1111.

Cushing, D. 1975. Fisheries resources of the sea and their management. London, Oxford University Press, 87p. 
Dekun, Z. \& Y. Cungen. 1987. The relation of the environment of fishing ground with the occurence of hairtail in winter off the middle part of Zhejiang. J. Fish. China, 11:195-204.

Dias-Neto, J. \& L. D. C. Dornelles. 1996. Diagnóstico da pesca marítima do Brasil. IBAMA, Brasília, Série Estudos de Pesca, 20, 163p.

Dinesh, K. R.; W. K. Chan; T. M. Lin \& V. P. E. Phang. 1995. RAPD markers in fishes: an evaluation of resolution and reproducibility. Asia Pacif. J. Mol. Biol. And Biotechnology, 3(2):112-118.

Efrom, B., 1985., Bootstrap confidence intervals for a class of parametric problems. Biometrika. 72: 45-58.

Emlen, S. T. \& L. W. Oring. 1977. Ecology, sexual selection, and the evolution of mating systems. Science, 197(4300):215-223.

Féral, J. P. 2002. How useful are the genetic markers in attempts to understand and manage marine biodiversity? J. Exp. Mar. Biol. Ecol. 268: 121-145.

Ferguson, A.; J. B. Taggart; P. A. Prodohl; O. McMeel; C. Thompson; C. Stone; P. McGinnity \& R. A. Hynes. 1995. Population and conservation. J. Fish. Biol., 47(Suppl. A):103-126.

Ferris, S. \& W. J. Berg. 1987. The utility of mitochondrial DNA in fish genetics and management. In: Ryman, N. \& F. UTTR (eds). Population genetics and fisheries management. University of Washington Press: 277-301.

Francis, R. I. C. C. 1990. Back-calculation of fish length: a critical rewiew. J. Fish. Biol., 36:883-902.

Fréon, P. \& O. A. Misund. Dynamics of pelagic fish distribution and behavior: effects on fisheries and stock assessment. Fishing News Book. Oxford. 348p.

Fundespa, 1994. Fundação de Estudos e Pesquisas Aquáticas. Diagnóstico ambiental oceânico e costeiro das regiões sudeste e sul do Brasil. 5 - Oceanografia Biológica: Nécton. S. Paulo, FUNDESPA. vol. V.

Galetti, P. M. Jr.; W. F. Molina; P. R. A. M. Affonso \& C. T. Aguilar. 2006. Assessing genetic diversity of Brazilian reef fishes by chromosomal and DNA markers. Genética, 126:161-177.

Gayanilo Jr., F. C. \& D. Pauly. 1997. FAO-ICLARM stock assessment tools. Reference manual. Computerized Information Series, fisheries. 262 p.

Graça-Lopes, R. da; E. Severino Rodrigues; A. Puzzi; B. Pitta; J. A. P. Coelho \& M. L. de FREITAS. 1993. Levantamento ictiofaunístico em um ponto fixo na Baía de Santos, Estado de São Paulo, Brasil. Bolm. Inst. Pesca, 20:7-20.

Haddon, M. 2001. Modelling and quantitative methods in fisheries. Chapman \& Hall/CRC Press. N.Y. 406p. 
Haimovici, M. 1997. Recursos pesqueiros demersais da região Sul. Rio de Janeiro: FEMAR, 1997. 80p.

Haimovici, M.; A. S. Martins \& P. C. Vieira. 1996. Distribuição e abundância de peixes teleósteos demersais sobre a plataforma continental do sul do Brasil. Rev. Bras. Biol., 56(1):27-50.

Haimovici, M.; A. S. Martins; J. L. de Figueiredo \& P. C. Vieira. 1994. Demersal bony fish of the outer shelf and upper slope of the southern Brazil subtropical convergence ecosystem. Mar. Ecol. Progr. Ser., 108(1/2):59-77.

Haimovici, M. \& R. P. Palacios. 1981. Observações sobre seleção a bordo e rejeição na pesca de arrasto de fundo no Rio Grande do Sul.In: Anais do II Congresso Brasileiro de Engenharia de Pesca, Recife, PE, pp.401-413.

Hamada, R. 1971. Age and growth of the ribbon fish, Trichiurus lepturus Linné, based on the transverse section of the otolith. Contribution from the SeikaiRegional Fisheries Research Laboratory, 272(41):53-81.

Hanabuchi, S. 1989. Age and growth of cutlassfish, Trichiurus lepturus, in the Tsushima waters. Bull. Seikai Reg. Fish Res. Lab. Seisuiken Kempo, 67:37-57.

Hilborn, R. \& C. J. Walters. 1992. Quantitative fisheries stock assessment - choice, dynamics \& uncertainty. Chapman \& Hall, New York, 570 p.

IBAMA. 1993. III Reunião do Grupo Permanente de Estudos (GPE) sobre peixes demersais, realizada no período de 1 a 5 de abril de 1991, no Centro de Pesquisa e Extensão Pesqueira das Regiões Sudeste-Sul (CEPSUL), Itajaí, SC./ Relatório Técnico, Instituto Brasileiro do Meio Ambiente e dos Recursos Naturais Renováveis/. Coleção Meio Ambiente, Série Estudos Pesca, v.8.

IBAMA, 1995. Peixes demersais: Relatório da 4 a Reunião do Grupo Permanente de Estudos, realizada no período de 08 a 12 de novembro de 1993. Itajaí: Instituto Brasileiro de Meio Ambiente e dos Recursos Naturais Renováveis, Centro de Pesquisas e Extensão Pesqueira das Regiões Sudeste e Sul do Brasil. 127. Coleção Meio Ambiente. Série Estudos de Pesca, no. 16.

IBAMA, 2004. Estatística da Pesca 2003 - Grandes Regiões e Unidades da Federação. Ministério do Meio Ambiente Instituto Brasileiro do Meio Ambiente e dos Recursos Naturais Renováveis. Diretoria de Fauna e Recursos PesqueirosDIFAP.Coordenação Geral de Gestão de Recursos Pesqueiros - CGREP

IBAMA, 2005. Estatística da Pesca 2004 - Grandes Regiões e Unidades da Federação. Ministério do Meio Ambiente Instituto Brasileiro do Meio Ambiente e dos Recursos Naturais Renováveis. Diretoria de Fauna e Recursos PesqueirosDIFAP.Coordenação Geral de Gestão de Recursos Pesqueiros - CGREP

Ihssen, P. E. ; H. E. Booke; J. M. Casselman; J. M. McGlade; N. R. Payne \& F. M. Utter. 1981. Stock identification: material and methods. Can. J. Fish. Aquat. Sci., 38(12): 1838-1855. 
Jaccard, P. 1901. Étude comparative de la distribution florale dans une portion des Alpes et des Jura. Bull. Soc. VaudoiseSci. Nat, 37:547-579.

Kimura, D. K. 1980. Likelihood methods for the von Bertalanffy growth curve. Fish. Bull., 77(4):765-776.

Kwok, K. Y. \& I. Ni 1999. Reproduction of cutlassfishes Trichiurus spp. from the South China Sea. Mar. Ecol. Progr. Ser., 176:39-47.

Kwok, K. Y. \& I. Ni. 2000. Age and growth of cutlassfishes, Trichiurus spp., from the South China Sea. Fish. Bull., 98: 748-758.

Lazarus, S. \& P. S. S. Sarma. 1991. The resource characteristics of the ribbonfish Trichiurus lepturus Linnaeus at Vizhinjam, southwest coast of India. J. Mar. Biol. Assoc. India, 33(1/2):89-98.

Lee, S. C.; S. C. M. Tsoi \& W. C. Chao. 1993. Biochemical systematics of Trichiurus lepturus and T. Japonicus (Perciformes, Trichiurudae) from Taiwan Strait. $Z$. Zool. Syst. Evolutiosforsch., 31(3):227-232.

Lima, D. 2005. Genética populacional molecular de corvinas (Micropogonias furnieri) brasileiras. Tese de Doutorado em Ciências Biológicas - Universidade Federal do Rio de Janeiro. Instituto de Biociências.

Lynch, M. \& B. G. Milligan. 1994. Analysis of population genetic structure with RAPD markers. Molecular Ecology, 3:91-99.

Magro, M. \& M. C. Cergole. 2000. Estudo sobre reprodução, idade e crescimento de Trichiurus lepturus da costa sudeste e sul do Brasil - Programa REVIZEE - Score Sul. Anais da XIII Semana Nacional de Oceanografia. Itajaí: CTTMar, p. 794796.

Magro, M. 2005. Trichiurus lepturus Linnaeus, 1758. In: Cergole, M. C.; A. O. Ávilada-Silva \& C. L. D. B. Rossi-Wongtschowski (eds). 2005. Análise das principais pescarias comerciais da região sudeste-sul do Brasil: Dinâmica populacional das espécies em explotação. Série Documentos REVIZEE - Score Sul. São Paulo. Instituto Oceanográfico - USP. 176p.

Magro, M.; M. C. Cergole \& C. L. D. B. Rossi-Wongtschowski. 2000. Síntese de conhecimentos dos principais recursos pesqueiros costeiros potencialmente explotáveis na costa sudeste-sul do Brasil: Peixes. MMA-CIRM, 145p.

Maltagliati, F.; P. Domenici; C. F. Fosch; P. Cossu; M. Casu \& A. Castelli. 2003. Small-scale morphological and genetic differentiation in the Mediterranean killifish Aphanius fasciatus (Cyprinodontidae) from a coastal brackish-water pond and an adjacent pool in northern Sardinia. Oceanologica Acta, 26:111-119.

Martins, A. S. 1992. Bioecologia do peixe-espada Trichiurus lepturus Linnaeus, 1758 no sul do Brasil. Dissertação de Mestrado. Universidade do Rio Grande, Rio Grande, Brasil. 143p. 
Martins, A. S. \& M. Haimovici. 1997. Distribution, abundance and biological interactions of the cutlassfish Trichiurus lepturus in the southern Brazil subtropical convergence ecosystem. Fish. Res., 30:217-227.

Martins, A. S. \& M. Haimovici. 2000. Reproduction of the cutlassfish Trichiurus lepturus in the southern Brazil subtropical convergence ecosystem. Scientia Marina, 64(1): 97-105.

Martins, A.; M. Haimovici \& R. Palacios. 2005. Diet and feeding of the cutlassfish Trichiurus lepturus in the Subtropical Convergence Ecosystem of southern Brazil. J. Mar. Biol. Ass. U.K., 85:1223-1229.

Masumoto, C. 2003. As atividades pesqueiras da comunidade caiçara de Picinguaba (Ubatuba, São Paulo). Dissertação de mestrado. Universidade de São Paulo, Instituto Oceanográfico. 103p.

Matsuoka, M.; M. Tokimura; H. Fujita \& T. Kitajima. 1993. A consideration on differences of catch compositions between daytime and nightime bottom trawl samplings in the East China Sea. Bull. Seikai Natl. Fish. Res. Inst. Seisuiken Кепро, 70:1-9.

Matsuura, Y. 1995. Exploração pesqueira - ambiente marinho no litoral brasileiro: 1-15. In: MMA, 1995. Os ecossistemas brasileiros e os principais macrovetores de desenvolvimento: subsídios ao planejamento da gestão ambiental. Ministério do Meio Ambiente, dos Recursos Hídricos e da Amazônia Legal, Secretaria de Coordenação dos Assuntos de Meio Ambiente, Programa Nacional do Meio Ambiente - PNMA - Brasília. 104p.

Matsuura, Y. 2001. Oceanos: Fonte de alimentos para o século 21. Ciência Hoje, 28(168):54-56.

Mendonça, J. T. 1998. A pesca na região de Cananéia - São Paulo, nos anos de 1995 e 1996. Dissertação de mestrado. Universidade de São Paulo, Instituto Oceanográfico. 110p.

Meng, Z.; Z. Zhuang; X. Jin; Q. Tang \& Y. Su. 2004. Analysis of RAPD and mitochondrial 16S rRNA gene sequences from Trichiurus lepturus and Eupleurogrammus muticus in the Yellow Sea. Progress in Nature Science. 14(2):125-131.

Miller, M. P. 1997. Tools for population genetics analyses TFPGA 1.3: A windows program for the analysis of allozyme and molecular population genetic data. Department of Biological Sciences, Northern Arizona University. MPM2@jan.ucc.nau.edu, Computer software distributed by author.

Munekiyo, M. 1990. Diurnal vertical migration of a ribbon fish in the western Wakasa Bay. Nippon Suisan Gakkaishi Bull. Jap. Sic. Sci. Fish., 56(8):1193-1197.

Munekiyo, M. \& A. Kuwahara. 1983. Some aspects of spawning schools of ribbon fish Trichiurus lepturus derived from catch records of experimental longline fishing. Bull. Jap. Soc. Sci. Fish. Nissuishi, 49(10):1515-1521. 
Munekiyo, M. \& A. Kuwahara. 1984a. Spawning ground, mating systems and distribution pattern of ribbon fish. Bull. Jap. Soc. Sci. Fish. Nissuishi, 50(9): 1527-1533.

Munekiyo, M. \& A. Kuwahara. 1984b. Spawning season and sex ratio of ribbon fish in the western Wakasa Bay. Bull. Jap. Soc. Sci. Fish. Nissuishi, 50(8): 1279-1284.

Munekiyo, M. \& A. Kuwahara. 1986. Eggs and larvae distribution of ribbon fish in the Western Wakasa Bay. Bull. Jap. Soc. Sci. Fish., 52(5):805-810.

Munekiyo, M. \& A. Kuwahara. 1988. Age and growth of ribbon fish in the western Wakasa Bay. Nippon. Suisan Gakkaishi Bull. Jap. Soc. Sci. Fish., 54(8):13051313.

Munekiyo, M. \& A. Kuwahara. 1988a. Maturity and spawning of ribbon fish in the western Wakasa Bay. Nippon. Suisan Gakkaishi Bull. Jap. Soc. Sci. Fish., 54(8):1315-1320.

Muto, E. Y.; M. H. C. Da Silva; G. R. Vera; S. S. M. Leite; D. G. Navarro \& C. L. D. B. Rossi-Wongtschowski. 2005. Alimentação e relações tróficas de peixes demersais da plataforma continental externa e talude superior da região sudeste-sul do Brasil. Instituto Oceanográfico - USP - Série Documentos REVIZEE: Score Sul. São Paulo. 64p.

Nakatami, K.; Y. Matsuura \& G. Sato. 1980. Estudo do ciclo de vida do peixe-espada Trichiurus lepturus. Bolm. Inst. oceanogr. São Paulo, 29(2):255-259.

Narasimham, K. A. 1976. Age and growth of ribbonfish Trichiurus lepturus Linnaeus. Indian J. Fish, 23(1-2):174-182.

Narasimham, K. A. 1983. On fishery, mortality rates and yield per recruit of ribbonfish Trichiurus lepturus Linnaeus. Indian J. Fish., 30(1):99-109.

Ney, M. 1978. Estimation of average heterozigosity and genetic distance from a small number of individuals. Genetics, 89:583-590.

Paiva, S. R. 2001. Divergência de populações de Astyanax bimaculatus na Bacia do Rio Doce - MG: Uma abordagem morfológica e molecular. Dissertação de Mestrado. Universidade Federal de Viçosa.

Park, C. S.; B. K. Hong \& D. W. Lee. 1996. Age and growth of hairtail (Trichiurus lepturus) in Korean waters. Bull. Nat. Fish. Res. Dev. Agency, 52: 15-24.

Pauly, D. 1980. On the interrelationships between natural mortality, growth parameters, and mean environmental temperature in 175 fish stocks. J. Cons. int. Explor. Mer., 39(2):175-192.

Perez, J. A. A.; P. R. Pezzuto; L. F. Rodrigues; H. Valentini \& C. M. VOOREN. (Relatores). 2001. Relatório da Reunião Técnica de Ordenamento da Pesca de Arrasto nas Regiões Sudeste e Sul do Brasil. Notas Técnicas da FACIMAR. 5:334. 
Pires-Vanin, A. M. S. \& Y. Matsuura.1993. Estrutura e função do ecossistema da plataforma continental da região de Ubatuba, Estado de São Paulo: uma introdução. Publ. Esp. Inst. oceanogr., São Paulo, 10:1-8.

Pitcher, T. J. 1995. The impact of pelagic fish behavior on fisheries. Scientia Marina, 59:295-306.

Pucci, M. C. J. 2004. Dieta e partilha alimentar de seis espécies de peixes da plataforma continental sudeste do Brasil. Dissertação de mestrado. Universidade de São Paulo.Instituto Oceanográfico. 137p.

Rolf, F. J. 1997. NTSYS-PC: Numerical taxonomy and multivariate analysis system. Versão 2.01e. Applied Bioestatistics. Steauket, New York.

Santos, S.; H. Schneider \& I. Sampaio. 2003. Genetic differentiation of Macrodon ancylodon (Sciaenidae, Perciformes) populations in Atlantic coastal waters of South America as revealed by mtDNA analysis. Genetics and Molecular Biology, 26(2):151-161.

Sastry, Y. A. 1984. Ribbonfish fishery of Kakinada area during 1977-80. Indian J. Fish., 31(3):337-344.

Schneider, S; J. M. Kueffer; D. Roessli \& L. Excoffier. 2000. Arlequin ver. 2.0: a software for population genetic analysis. Genetics and Biometry Laboratory, University of Geneva, Switzerland.

Seckendorff, R. W.; M. H. Carneiro \& M. R. de Souza. 2000. A atividade pesqueira no litoral norte do Estado de São Paulo: Uma análise das capturas da rede de cerco flutuante. In: XIII Semana Nacional de Oceanografia. 29 out - 03 nov: 500 anos de mar brasileiro. Itajaí, SC, 2000.Universidade do Vale do Itajaí. Centro de Ciências Tecnológicas da Terra e do Mar-CTTMar.

Sheridan, P. F.; D. L. Trimm \& B. M. Baker. 1984. Reproduccion and food habits of seven species of northern Gulf of Mexico fishes. Contr. Mar. Sci., Univ. Texas, 27:175-204.

Silva, E. P. \& C. A. M. Russo. 2000. Techniques and statistical data analysis in molecular population genetics. Hydrobiologia, 420: 119-135.

Silveira, I. C. A. da; A. C. K. Schmidt; E. J. D. Campos; S. S. de Godoi \& Y. Ikeda. 2000. A Corrente do Brasil ao largo da costa leste brasileira. Rev. bras. oceanogr., 48(2):171-183.

Smith, P. J.; P. G. Benson \& S. M. McVeagh. 1997. A comparison of three genetic methods used for stock discrimination of orange roughy, Hoplostethus atlanticus: allozymes, mitochondrial DNA, and random amplified polymorphic DNA. Fish. Bull. US, 95:800-811.

Solé-Cava, A. M. 2001.Biodiversidade molecular e genética da conservação. In: Matioli, S. R., ed. Biologia Molecular e Evolução. Holos, Editora. Riberão Preto SP. P.172-192. 
Somvanshi, V. S. \& A. Joseph. 1989. Population dynamics and assessment of Trichiurus lepturus Linnaeus stock in north-west coast of India. Spec. Publ. Fish. Surv. India, 2:1-32.

Sparre, P. \& S. C. Venema. 1998. Introduction to tropical fish stocks assessment . Part I: Manual. FAO Fish. Tech. Pap. 306/1 (Rev. 2): 407p.

Ssentongo, G. W. \& P. A. Larkin. 1973. Some simple methods of estimating mortality rates of exploited fish populations. J. Fish. Res. Board Can., 30:695-698.

STOCS. 1981. Stock Concept International Symposium. Can. J. Fish. Aq. Sci., 38(12):1457-1921.

Taggart, J. B.; R. A. Hynes; P. A. Prodohl \& A. Fergusson. 1992. A simplified protocol for routine total DNA isolation from salmonid fishes. Journal of Fish Biology, 40:963-965.

Tampi, P. R. S.; P. T. Meenakshisundaram; S. Basheeruddin \& J. C. Gnanamuttu. 1968. Spawning periodicity of the ribbon fish, Trichiurus lepturus (F.), with a note on its rate of growth. Indian J. Fish., 15(1/2):53-60.

UTHSCSA, 1996. Image Tool. University of Texas Health Science Center at San Antonio, Texas. http://ddsdx.uthscsa.edu/dig/itdesc.html

V PSRM. 1999. V Plano Setorial para os Recursos do Mar (1999 - 2003). Comissão Interministerial para os Recursos do Mar, Brasília, 38p.

Valentini, H.; P. M. G. de Castro; G. J. DE M. Servo; L. A. B. de Castro. 1991. Evolução da pesca das principais espécies demersais da costa sudeste do Brasil, pela frota de arrasteiros de parelhas baseada em São Paulo, de 1968 a 1987. Atlântica, Rio Grande, 13(1): 87-95.

Vazzoler, A. E. A. de M. 1996. Biologia reprodutiva de peixes teleósteos: teoria e prática. Maringá, Editora da Universidade Estadual de Maringá (EDUEM). 169p.

Wang, K; P. Zhang; L. Liu; F. You; J. Liu; C. Xu \& J. Wang. 1994. Biochemical genetic structure and identification of hairtail fish (Trichiurus) populations in Chinese coastal waters. Acta Oceanol. Sin. Haiyang Xuebao, 13(4):565-577.

Williams, J. G. K.; A. R. Kulebik; K. J. Livak; J. Á. Rafalski \& S. V. Tingey. 1990. DNA polymorphism amplified by arbitrary primers are useful as genetic markers. Nucl. Acids. Res. 18: 474-491.

Wootton, R. J. 1989. Introduction: strategies and tatics in fish reproduction. In: Potts, G. W. \& M. N. Wootton (Ed.) Fish reproduction: strategies and tatics. Academic Press, London. 410p.

Yáñez-Arancibia, A. \& P. Sánchez-Gil. 1988. Ecologia de los recursos demersales marinos. México, D. F., A. G. T. Editor. 228p. 
Yap, I. V. \& R. J. Nelson. 1996. Winboot: A program for performing bootstrap analysis of binary data to determine the confidence limits of UPGMA-based dendrograms. IRRI. International Rice Research Institute . Manilla. Philippines.

Zar, J. H. 1999. Biostatistical Analysis (4a ${ }^{\mathrm{a}}$ ed.). Prentice Hall, New Jersey. 663p + apêndices.

Zhang, C. I. 1997. Estimation of population ecological characteristics of hairtail, Trichiurus lepturus Linneus in Korean waters. Bull. Fac. Bioresour. Mie. Univer., 17:83-89. 


\section{TABELAS}

Tabela 01: Produção pesqueira anual das principais espécies capturadas na região de Arraial do Cabo (RJ) no período de 1992 a 2002 , fornecida por MSc. Paulo José de Azevedo Silva (FIPAC)

\begin{tabular}{|c|c|c|c|c|c|c|c|c|c|c|c|c|c|}
\hline Família & Espécie & Nome Vulgar & 1992 & 1993 & 1994 & 1995 & 1996 & 1997 & 1998 & 1999 & 2000 & 2001 & 2002 \\
\hline Clupeidae & Sardinella brasiliensis & Sardinha Verdadeira & 92.94 & 99.93 & 304.75 & 1217.57 & 199.72 & 547.49 & 110.24 & 272.33 & 201.11 & 144.96 & 153.88 \\
\hline Pomatomidae & Pomatomus saltator & Enchova & 131.46 & 381.05 & 361.84 & 362.53 & 284.06 & 239.26 & 294.74 & 255.90 & 163.64 & 158.62 & 152.85 \\
\hline Trichiuridae & Trichiurus lepturus & Espada & 41.52 & 28.87 & 20.34 & 65.01 & 168.96 & 183.60 & 219.26 & 343.64 & 556.88 & 570.57 & 318.10 \\
\hline Scombridae & Euthynnus alleteratus & Bonito-Pintado & 42.37 & 268.54 & 178.18 & 130.66 & 73.15 & 128.75 & 47.31 & 275.91 & 57.06 & 181.50 & 174.14 \\
\hline Scombridae & Scomber japonicus & Cavalinha & 206.93 & 8.18 & 38.46 & 685.77 & 45.53 & 56.38 & 216.40 & 18.30 & 25.31 & 0.10 & 26.54 \\
\hline Carangidae & Caranx crysos & Xerelete & 105.09 & 50.90 & 69.80 & 61.05 & 202.32 & 79.77 & 147.43 & 138.68 & 212.11 & 106.71 & 89.65 \\
\hline Coryphaenidae & Coryphaena hippurus & Dourado & 43.82 & 28.60 & 98.65 & 159.64 & 13.05 & 120.02 & 78.80 & 233.17 & 276.14 & 87.70 & 1.60 \\
\hline Carangidae & Selene setapinnis & Galo & 99.35 & 64.99 & 130.93 & 65.07 & 30.56 & 25.61 & 0.37 & 8.90 & 9.00 & 9.52 & 1.20 \\
\hline Mugiloididae & Pseudopercis numida & Namorado & 0.00 & 28.80 & 40.35 & 15.23 & 4.98 & 22.38 & 55.85 & 130.24 & 54.58 & 19.34 & 5.40 \\
\hline Clupeidae & Opisthonema oglinum & Sardinha lage & 0.00 & 8.38 & 173.69 & 125.16 & 5.19 & 0.00 & 0.00 & 0.00 & 0.00 & 0.00 & 25.52 \\
\hline Scombridae & Sarda sarda & Serra & 53.41 & 37.43 & 73.50 & 57.23 & 23.68 & 0.00 & 0.00 & 0.00 & 0.00 & 28.40 & 5.71 \\
\hline Carangidae & Chloroscombrus chrysurus & Palombeta & 7.00 & 7.83 & 12.71 & 15.89 & 1.59 & 1.08 & 7.45 & 49.85 & 47.30 & 94.04 & 10.51 \\
\hline Mugilidae & Mugil curema & Parati & 0.00 & 0.05 & 0.34 & 13.70 & 8.84 & 13.46 & 1.79 & 166.37 & 19.74 & 0.64 & 8.67 \\
\hline Mugilidae & Mugil liza & Tainha & 11.88 & 15.01 & 68.27 & 30.02 & 10.60 & 10.41 & 34.82 & 21.36 & 4.19 & 3.73 & 2.10 \\
\hline Carangidae & Caranx hippos & Xaréu & 26.60 & 4.98 & 65.27 & 7.84 & 30.29 & 8.86 & 3.20 & 0.00 & 11.37 & 0.20 & 0.00 \\
\hline \multirow[t]{4}{*}{ Decapoda } & Loligo plei & Lula & 25.27 & 14.71 & 35.92 & 35.91 & 53.08 & 87.56 & 12.20 & 118.62 & 271.39 & 139.87 & 102.88 \\
\hline & & Outros & 145.37 & 241.82 & 196.09 & 123.05 & 177.40 & 154.28 & 169.42 & 277.54 & 159.42 & 117.42 & 97.18 \\
\hline & & Total & 1033.01 & 1290.07 & 1869.07 & 3171.31 & 1332.99 & 1678.91 & 1399.25 & 2310.80 & 2069.24 & 1663.31 & 1175.93 \\
\hline & & $\%$ Espada & 4.02 & 2.24 & 1.09 & 2.05 & 12.67 & 10.94 & 15.67 & \begin{tabular}{l|l}
14.87 \\
\end{tabular} & 26.91 & 34.30 & 27.05 \\
\hline
\end{tabular}


Tabela 02: Dados de desembarques de todas as artes de pesca que apresentaram T. lepturus em suas capturas, fornecidos pelo Instituto de Pesca-SP.

\begin{tabular}{|c|c|c|c|c|c|c|c|c|}
\hline Ano & $\mathbf{1 9 9 8}$ & $\mathbf{1 9 9 9}$ & $\mathbf{2 0 0 0}$ & $\mathbf{2 0 0 1}$ & $\mathbf{2 0 0 2}$ & $\mathbf{2 0 0 3}$ & $\mathbf{2 0 0 4}$ & Total \\
\hline $\begin{array}{c}\text { No. de } \\
\text { desembarques }\end{array}$ & 385 & 831 & 779 & 800 & 960 & 1056 & 1207 & 6018 \\
\hline $\begin{array}{c}\text { Captura total } \\
\text { (kg) }\end{array}$ & 3.082 .880 & 5.273 .487 & 6.230 .931 & 7.055 .363 & 6.848 .920 & 8.148 .583 & 9.125 .156 & 45.765 .320 \\
\hline $\begin{array}{c}\text { Captura } \\
\text { Espada (kg) }\end{array}$ & 83.021 & 116.702 & 245.107 & 240.010 & 236.399 & 306.129 & 304.481 & 1.531 .849 \\
\hline$\%$ Espada & 2,69 & 2,21 & 3,93 & 3,40 & 3,45 & 3,76 & 3,34 & 3,35 \\
\hline
\end{tabular}

Tabela 03: Participação relativa de Trichiurus lepturus ao nível explicativo de $80 \%$ na arte de pesca de linha-de-mão e arrasto de fundo com parelhas desenvolvidas na costa de São Paulo, no período de 1998 a 2004.

\begin{tabular}{|c|c|c|}
\hline Ano & Linha-de-mão & Parelha \\
\hline $\mathbf{1 9 9 8}$ & 62 & 0 \\
\hline $\mathbf{1 9 9 9}$ & 46 & 0 \\
\hline $\mathbf{2 0 0 0}$ & 30 & 0 \\
\hline $\mathbf{2 0 0 1}$ & 50 & 2 \\
\hline $\mathbf{2 0 0 2}$ & 80 & 2 \\
\hline $\mathbf{2 0 0 3}$ & 74 & 2 \\
\hline $\mathbf{2 0 0 4}$ & 30 & 2 \\
\hline
\end{tabular}


Tabela 04: Produção pesqueira mensal das principais espécies capturadas em três cercos flutuantes localizados na região de Porto Belo (SC), de propriedade da Empresa Pioneira da Costa S.A., no período de maio de 2002 a abril de 2003.

\begin{tabular}{|c|c|c|c|c|c|c|c|c|c|c|c|c|}
\hline \multicolumn{1}{c}{} & \multicolumn{9}{|c|}{2002} & \multicolumn{5}{c|}{2003} \\
\hline Espécie & $\mathbf{5}$ & $\mathbf{6}$ & $\mathbf{7}$ & $\mathbf{8}$ & $\mathbf{9}$ & $\mathbf{1 0}$ & $\mathbf{1 1}$ & $\mathbf{1 2}$ & $\mathbf{1}$ & $\mathbf{2}$ & $\mathbf{3}$ & $\mathbf{4}$ \\
\hline espada & $\mathbf{3 4 0 1}$ & & $\mathbf{7 7 4 1}$ & $\mathbf{1 6 2 2 5}$ & $\mathbf{8 7 4 9}$ & $\mathbf{1 3 5 9 7}$ & $\mathbf{2 5 2 7}$ & $\mathbf{1 1 6 2}$ & $\mathbf{4 2 3 0}$ & $\mathbf{5 6 7 2}$ & $\mathbf{2 0 0 8}$ & $\mathbf{1 3 8 9}$ \\
\hline gordinho & 40 & & & 8 & 129 & 105 & & & & 12 & & \\
\hline sardinha & & & & & & 82 & & & & 343 & & \\
\hline palombeta & 151 & & & & & & & & 6 & 12 & 75 & 524 \\
\hline galo & 130 & & & & 50 & & 30 & 245 & 359 & & 9 & 50 \\
\hline mistura & 109 & & 135 & 107 & 236 & 209 & 200 & 121 & 154 & 189 & 104 & 215 \\
\hline xixarro & & & 1850 & & & & & & & & & \\
\hline sororoca & 14 & & 65 & 289 & 592 & 144 & 181 & & 99 & 152 & 51 & 290 \\
\hline xerelete & 104 & & 10 & 811 & 893 & 880 & 259 & 162 & 604 & 337 & 607 & 559 \\
\hline sardinha-lage & & & & & 162 & 649 & & & 200 & 8320 & 6 & 196 \\
\hline outros & 30 & & 237 & 114 & 204 & 79 & 43 & 9 & 335 & 237 & 38 & 15 \\
\hline Total (kg) & 3979 & & 10038 & 17554 & 11015 & 15745 & 3240 & 1699 & 5987 & 15274 & 2898 & 3238 \\
\hline
\end{tabular}


Tabela 05: A - Análise molecular de variância (AMOVA) dos 108 exemplares de T. lepturus. B - Tabela de $\Phi$ st pareado. Entre parenteses - não significativamente diferente de zero. 1 - Belém (PA), 2 - Natal (RN), 3 - Arraial do Cabo (RJ), 4 - Guarujá (SP), 5 - Porto Belo (SC), 6 - Rio Grande (RS).

A

\begin{tabular}{ccccc}
\hline Fonte de variação & d.f. & SQ & Variância & $\begin{array}{c}\text { \% de } \\
\text { Variação }\end{array}$ \\
\hline Entre populações & 5 & 4,370 & 0,0220 & 4,41 \\
Dentro da população & 102 & 48,722 & 0,4776 & 95,59 \\
\hline Total & 107 & 53,093 & & \\
\hline$\Phi s t$ & $\mathbf{0 , 0 4 4 0 7}$ & & & \\
\hline
\end{tabular}

B

\begin{tabular}{ccccccc}
\hline Regiões & $\mathbf{1}$ & $\mathbf{2}$ & $\mathbf{3}$ & $\mathbf{4}$ & $\mathbf{5}$ & $\mathbf{6}$ \\
\hline $\mathbf{1}$ & $* * * * * *$ & & & & & \\
$\mathbf{2}$ & 0,0719 & $* * * * * *$ & & & & \\
$\mathbf{3}$ & 0,0849 & 0,0261 & $* * * * * *$ & & & \\
$\mathbf{4}$ & 0,0784 & 0,0196 & 0,0297 & $* * * * * *$ & & \\
$\mathbf{5}$ & 0,0915 & 0,0327 & 0,0457 & 0,0392 & $* * * * * *$ & \\
$\mathbf{6}$ & 0,0686 & $(0,0098)$ & $(0,0223)$ & $(0,0163)$ & 0,0234 & $* * * * * *$ \\
\hline
\end{tabular}

Tabela 06: Matriz de distâncias genéticas (acima da diagonal) e de identidade (abaixo da diagonal) de Nei (1978) com correção de Lynch \& Milligan (1994) para as regiões pareadas. 1 - Belém (PA), 2 - Natal (RN), 3 - Arraial do Cabo (RJ), 4 - Guarujá (SP), 5 - Porto Belo (SC), 6 - Rio Grande (RS).

\begin{tabular}{ccccccc}
\hline Regiões & $\mathbf{1}$ & $\mathbf{2}$ & $\mathbf{3}$ & $\mathbf{4}$ & $\mathbf{5}$ & $\mathbf{6}$ \\
\hline $\mathbf{1}$ & $* * * * * *$ & 0,1236 & 0,1480 & 0,1167 & 0,1646 & 0,1545 \\
$\mathbf{2}$ & 0,8838 & $* * * * * *$ & 0,0318 & 0,0223 & 0,0449 & 0,0328 \\
$\mathbf{3}$ & 0,8624 & 0,9687 & $* * * * * *$ & 0,0189 & 0,0117 & 0,0103 \\
$\mathbf{4}$ & 0,8898 & 0,9779 & 0,9813 & $* * * * * *$ & 0,0338 & 0,0265 \\
$\mathbf{5}$ & 0,8482 & 0,9561 & 0,9884 & 0,9668 & $* * * * * *$ & 0,0049 \\
$\mathbf{6}$ & 0,8568 & 0,9677 & 0,9897 & 0,9739 & 0,9951 & $* * * * * *$ \\
\hline
\end{tabular}


Tabela 07: Descrição das amostras de número de raios da primeira nadadeira dorsal dos exemplares de $T$. lepturus de cada região amostrada, por sexo. RJF e RJM - fêmeas e machos do Rio de Janeiro; SPF e SPM - fêmeas e machos de São Paulo; SCF e SCM - fêmeas e machos de Santa Catarina; $\mathrm{n}$ - número da amostra; $\mathrm{dp}$ - desvio padrão; Min e Max - limites da amplitude dos dados; stg1 - simetria estandartizada; stg2 - curtose estandartizada.

\begin{tabular}{|c|c|c|c|c|c|c|}
\cline { 2 - 7 } \multicolumn{1}{c|}{} & RJF & RJM & SPF & SPM & SCF & SCM \\
\hline $\mathbf{n}$ & 233 & 46 & 139 & 146 & 190 & 63 \\
\hline Média & 132,30 & 132,41 & 132,37 & 132,40 & 132,48 & 133,30 \\
\hline dp & 1,711 & 1,758 & 1,490 & 1,642 & 2,067 & 2,084 \\
\hline Min & 129 & 129 & 129 & 129 & 127 & 129 \\
\hline Max & 136 & 136 & 136 & 136 & 138 & 138 \\
\hline stg1 & 1,027 & 0,205 & 0,200 & 1,191 & 0,784 & 0,869 \\
\hline stg2 & $-1,523$ & $-0,700$ & $-1,260$ & $-1,231$ & $-0,041$ & $-0,453$ \\
\hline
\end{tabular}

Tabela 08: Probabilidades dos testes de variância (teste F), testes de igualdade de médias (teste t), teste de homocedasticidade (Bartlett) e de comparação de medianas (Kruskal-Wallis) para o número de raios da segunda nadadeira dorsal dos exemplares de T. lepturus. RJF e RJM - fêmeas e machos do Rio de Janeiro; SPF e SPM - fêmeas e machos de São Paulo; SCF e SCM - fêmeas e machos de Santa Catarina. * Diferença significativa ao nível de significância de 5\%.

\begin{tabular}{|c|c|c|}
\hline Grupos & Teste $\mathbf{F}$ & Teste t \\
\hline RJF x RJM & 0,7704 & 0,6850 \\
\hline SPF x SPM & 0,2515 & 0,9010 \\
\hline SCF x SCM & 0,9088 & $0,0033 *$ \\
\hline
\end{tabular}

\begin{tabular}{|c|c|c|}
\hline Grupos & Teste de Bartlett & Teste de Kruskal-Wallis \\
\hline RJ SP SCF SCM & $6,84 \mathrm{e}-5 *$ & $7,75 \mathrm{e}-3 *$ \\
\hline
\end{tabular}


Tabela 09: Teste de comparação múltipla não-paramétricos a posteriori para dados desbalanceados aplicado aos dados de número de raios da segunda nadadeira dorsal de T. lepturus dos grupos de diferentes Estados.

\begin{tabular}{ccccc} 
Amostra & ordem & Rank médio & $\mathbf{N}$ & In s $^{\mathbf{2}}$ \\
& & & & \\
RJ & 4 & 392.711 & 279 & 5.9731 \\
SP & 3 & 401.918 & 285 & 5.9962 \\
SCFem & 2 & 412.463 & 190 & 6.0221 \\
SCMac & 1 & 502.730 & 63 & 6.2201 \\
\cline { 2 - 3 } & $\mathrm{N}=$ & 817 & &
\end{tabular}

$\begin{array}{ccccccc}\text { Comparação } & \text { Diferença } & \text { SE } & \boldsymbol{q} & \mathbf{q} \text { (0.05,oo,p } & \text { Conclusão } & \mathbf{P} \\ & & & & & & \\ 1 \times 4 & 110.019 & 32.918 & 3.342 & 2.639 & \text { diferem } & 0.005 \\ 1 \times 3 & 100.812 & 32.854 & 3.068 & 2.639 & \text { diferem } & 0.015 \\ 1 \times 2 & 90.2670 & 34.309 & 2.631 & 2.639 & \text { não diferem } & 0.052 \\ 2 \times 4 & 19.7520 & 22.198 & 0.890 & 2.639 & \text { não diferem } & >0.5 \\ 2 \times 3 & 10.5450 & 22.103 & 0.477 & 2.639 & \text { não diferem } & >0.5 \\ 3 \times 4 & 9.207 & 19.875 & 0.463 & 2.639 & \text { não diferem } & >0.5\end{array}$

\begin{tabular}{|cccc|}
\hline $\mathbf{1}$ & $\mathbf{2}$ & $\mathbf{3}$ & $\mathbf{4}$ \\
SCM & SCF & SP & RJ \\
502.730 & 412.463 & 401.918 & 392.711 \\
& & \\
\hline
\end{tabular}

Tabela 10: Descrição das amostras de comprimento total $(\mathrm{Lt}-\mathrm{mm})$ dos exemplares de T. lepturus de cada região amostrada, por sexo. RJF e RJM - fêmeas e machos do Rio de Janeiro; SPF e SPM - fêmeas e machos de São Paulo; SCF e SCM - fêmeas e machos de Santa Catarina; n número da amostra; dp - desvio padrão; Min e Max - limites da amplitude dos dados; stg1 simetria estandartizada; stg2 - curtose estandartizada.

\begin{tabular}{|c|c|c|c|c|c|c|}
\cline { 2 - 7 } \multicolumn{1}{c|}{} & RJF & RJM & SPF & SPM & SCF & SCM \\
\hline $\mathbf{n}$ & 384 & 75 & 433 & 451 & 456 & 138 \\
\hline Média & 1120,44 & 1030,17 & 960,08 & 950,98 & 936,98 & 858,93 \\
\hline dp & 115,76 & 136,59 & 291,58 & 231,21 & 162,93 & 153,49 \\
\hline Mediana & 1155,95 & 1064,0 & 1020,0 & 1035,0 & 923,5 & 828,0 \\
\hline Min & 603 & 610 & 342 & 364 & 328 & 484 \\
\hline Max & 1436 & 1262 & 1553 & 1330 & 1573 & 1213 \\
\hline stg1 & $-9,489$ & $-3,728$ & $-3,860$ & $-7,840$ & 3,124 & 1,891 \\
\hline stg2 & 5,607 & 1,505 & $-3,495$ & $-1,063$ & 3,761 & $-0,335$ \\
\hline
\end{tabular}


Tabela 11: Descrição das amostras de peso total $(\mathrm{Wt}-\mathrm{g})$ dos exemplares de T. lepturus de cada região amostrada, por sexo. RJF e RJM - fêmeas e machos do Rio de Janeiro; SPF e SPM - fêmeas e machos de São Paulo; SCF e SCM - fêmeas e machos de Santa Catarina; n - número da amostra; dp - desvio padrão; Min e Max - limites da amplitude dos dados; stg1 - simetria estandartizada; $\operatorname{stg} 2$ - curtose estandartizada.

\begin{tabular}{|c|c|c|c|c|c|c|}
\cline { 2 - 7 } \multicolumn{1}{c|}{} & RJF & RJM & SPF & SPM & SCF & SCM \\
\hline $\mathbf{n}$ & 384 & 75 & 433 & 451 & 456 & 138 \\
\hline Média & 920,35 & 703,91 & 674,44 & 597,58 & 543,36 & 406,53 \\
\hline dp & 341,23 & 267,38 & 527,74 & 351,75 & 359,75 & 259,69 \\
\hline Mediana & 957,55 & 738,0 & 598,9 & 670,0 & 445,0 & 315,0 \\
\hline Min & 112,5 & 90,9 & 12,0 & 16,5 & 14,8 & 49,5 \\
\hline Max & 1734,0 & 1318,0 & 2530,7 & 1695,0 & 2995,0 & 1210,0 \\
\hline stg1 & $-2,739$ & $-0,991$ & 5,916 & $-0,736$ & 18,197 & 5,571 \\
\hline stg2 & $-0,843$ & $-0,151$ & $-0,542$ & $-4,281$ & 29,413 & 1,386 \\
\hline
\end{tabular}

Tabela 12: Parâmetros da relação potencial $\left(y=a \cdot x^{b}\right)$ entre comprimento anal e comprimento total dos exemplares de $T$. lepturus por sexo e agrupados obtidos para os diferentes Estados analisados e seus respectivos desvios padrão (parênteses). RJF, RJM e RJ - fêmeas, machos e agrupados do Rio de Janeiro; SPF, SPM e SP - fêmeas, machos e agrupados de São Paulo; SCF, SCM e $\mathrm{SC}$ - fêmeas, machos e agrupados de Santa Catarina; a - intercepto; b - inclinação; $\mathrm{r}^{2}-$ coeficiente de determinação; $\mathrm{n}$ - número amostral.

\begin{tabular}{|c|c|c|c|c|}
\hline & $\mathbf{a}$ & b & $\mathbf{r}^{2}$ & $\mathrm{n}$ \\
\hline RJF & $\begin{array}{c}0,0399 \\
(0,0027)\end{array}$ & $\begin{array}{c}1,3273 \\
(0,0095)\end{array}$ & 0,986 & 384 \\
\hline RJM & $\begin{array}{c}0,0391 \\
(0,0059) \\
\end{array}$ & $\begin{array}{c}1,330 \\
(0,0215) \\
\end{array}$ & 0,985 & 75 \\
\hline RJ & $\begin{array}{c}0,040 \\
(0,002)\end{array}$ & $\begin{array}{c}1,328 \\
(0,008)\end{array}$ & 0,986 & 459 \\
\hline SPF & $\begin{array}{c}0,0648 \\
(0,0025)\end{array}$ & $\begin{array}{c}1,2599 \\
(0,0055)\end{array}$ & 0,995 & 433 \\
\hline SPM & $\begin{array}{c}0,0612 \\
(0,0032) \\
\end{array}$ & $\begin{array}{c}1,268 \\
(0,0074) \\
\end{array}$ & 0,991 & 451 \\
\hline SP & $\begin{array}{c}0,069 \\
(0,002)\end{array}$ & $\begin{array}{c}1,251 \\
(0,003)\end{array}$ & 0,995 & 1139 \\
\hline SCF & $\begin{array}{c}0,0503 \\
(0,0034)\end{array}$ & $\begin{array}{c}1,2964 \\
(0,0099)\end{array}$ & 0,974 & 456 \\
\hline SCM & $\begin{array}{c}0,0452 \\
(0,0053)\end{array}$ & $\begin{array}{c}1,3121 \\
(0,0172)\end{array}$ & 0,977 & 138 \\
\hline SC & $\begin{array}{c}0,061 \\
(0,003)\end{array}$ & $\begin{array}{c}1,268 \\
(0,007)\end{array}$ & 0,986 & 707 \\
\hline
\end{tabular}


Tabela 13: Parâmetros da relação potencial $\left(y=a \cdot x^{b}\right)$ entre comprimento total e comprimento anal dos exemplares de T. lepturus por sexo e agrupados obtidos para os diferentes Estados analisados e seus respectivos desvios padrão (parênteses). RJF, RJM e RJ - fêmeas, machos e agrupados do Rio de Janeiro; SPF, SPM e SP - fêmeas, machos e agrupados de São Paulo; SCF, SCM e $\mathrm{SC}$ - fêmeas, machos e agrupados de Santa Catarina; $\mathrm{a}$ - intercepto; $\mathrm{b}$ - inclinação; $\mathrm{r}^{2}$ coeficiente de determinação; $\mathrm{n}$ - número amostral.

\begin{tabular}{|c|c|c|c|c|}
\cline { 2 - 5 } \multicolumn{1}{c|}{} & $\mathbf{a}$ & $\mathbf{b}$ & $\mathbf{r}^{2}$ & $\mathbf{n}$ \\
\hline \multirow{2}{*}{ RJF } & $\begin{array}{c}12,0165 \\
(0,3661)\end{array}$ & $\begin{array}{c}0,7437 \\
(0,005)\end{array}$ & 0,987 & 384 \\
\hline \multirow{2}{*}{$\mathbf{R J}$} & $\begin{array}{c}12,3452 \\
(0,8663)\end{array}$ & $\begin{array}{c}0,7392 \\
(0,0117)\end{array}$ & 0,985 & 75 \\
\hline SPF & $\begin{array}{c}12,042 \\
(0,326)\end{array}$ & $\begin{array}{c}0,743 \\
(0,004)\end{array}$ & 0,987 & 459 \\
\hline SPM & $\begin{array}{c}8,7617 \\
(0,1695)\end{array}$ & $\begin{array}{c}0,7939 \\
(0,0032)\end{array}$ & 0,995 & 433 \\
\hline SP & $\begin{array}{c}9,3284 \\
(0,2296)\end{array}$ & $\begin{array}{c}0,7834 \\
(0,0041)\end{array}$ & 0,992 & 451 \\
\hline SCF & $\begin{array}{c}8,470 \\
(0,101)\end{array}$ & $\begin{array}{c}0,799 \\
(0,002)\end{array}$ & 0,995 & 1139 \\
\hline SCM & $\begin{array}{c}11,1549 \\
(0,3886)\end{array}$ & $\begin{array}{c}0,7535 \\
(0,0059)\end{array}$ & 0,973 & 456 \\
\hline SC & $\begin{array}{c}11,4023 \\
(0,6435)\end{array}$ & $\begin{array}{c}0,7493 \\
(0,0097)\end{array}$ & 0,978 & 707 \\
\hline
\end{tabular}


Tabela 14 - Análise de covariância dos modelos relacionando comprimento total (variável dependente) e sexo (variável categórica) e comprimento anal (covariável), nos diferentes Estados analisados.

Rio de Janeiro: Comprimento total $(\mathrm{Lt})=$ constante + Comprimento anal $(\mathrm{La})+$ sexo + sexo * $(\mathrm{La})$

\begin{tabular}{lccccccc}
\hline $\begin{array}{c}\text { Fonte de } \\
\text { Variação }\end{array}$ & SQ & gl & MQ & F & P & $\mathbf{r}^{\mathbf{2}}$ & n \\
\hline La & 4671420.476 & 1 & 4671420.476 & 11852.377 & $1.06 \mathrm{E}-11$ & 0.984 & 459 \\
Sexo & 261.356 & 1 & 261.356 & 0.663 & 0.416 & & \\
Sexo* La & 374.424 & 1 & 374.424 & 0.950 & 0.330 & & \\
Erro & 179330.811 & 455 & 394.134 & & & \\
\hline
\end{tabular}

São Paulo: Comprimento total $(\mathrm{Lt})=$ constante + Comprimento anal $(\mathrm{La})+\operatorname{sexo}+$ sexo * $(\mathrm{La})$

\begin{tabular}{lccccccc}
\hline $\begin{array}{c}\text { Fonte de } \\
\text { Variação }\end{array}$ & SQ & gl & MQ & F & P & $\mathbf{r}^{2}$ & n \\
\hline La & $5.74787 \mathrm{E}+07$ & 1 & $5.74787 \mathrm{E}+07$ & 80622.352 & $8.85 \mathrm{E}-12$ & 0.990 & 884 \\
Sexo & 192.711 & 1 & 192.711 & 0.270 & 0.603 & & \\
Sexo* La & 65.489 & 1 & 65.489 & 0.092 & 0.762 & & \\
Erro & 627384.905 & 880 & 712.937 & & & \\
\hline
\end{tabular}

Santa Catarina: Comprimento total $(\mathrm{Lt})=$ constante + Comprimento anal $(\mathrm{La})+\operatorname{sexo}+$ sexo $*(\mathrm{La})$

\begin{tabular}{lccccccc}
\hline $\begin{array}{c}\text { Fonte de } \\
\text { Variação }\end{array}$ & SQ & gl & MQ & F & P & $\mathbf{r}^{2}$ & n \\
\hline La & 9810021.910 & 1 & 9810021.910 & 13252.927 & $1.05 E-11$ & 0.973 & 594 \\
Sexo & 1147.433 & 1 & 1147.433 & 1.550 & 0.214 & & \\
Sexo* La & 744.125 & 1 & 744.125 & 1.005 & 0.316 & & \\
Erro & 436727.152 & 590 & 740.216 & & & \\
\hline
\end{tabular}


Tabela 15: Parâmetros da relação potencial $\left(y=a \cdot x^{b}\right)$ entre peso total e comprimento total dos exemplares de T. lepturus por sexo e agrupados obtidos para os diferentes Estados analisados e seus respectivos desvios padrão (parênteses). RJF, RJM e RJ - fêmeas, machos e agrupados do Rio de Janeiro; SPF, SPM e SP - fêmeas, machos e agrupados de São Paulo; SCF, SCM e SC fêmeas, machos e agrupados de Santa Catarina; $a$ - intercepto; $b$ - inclinação; $\mathrm{r}^{2}$ - coeficiente de determinação; $\mathrm{n}$ - número amostral.

\begin{tabular}{|c|c|c|c|c|}
\cline { 2 - 5 } \multicolumn{1}{c|}{$\mathbf{a}$} & $\mathbf{b}$ & $\mathbf{r}^{\mathbf{2}}$ & $\mathbf{n}$ \\
\hline \multirow{2}{*}{$\mathbf{R J}$} & $\begin{array}{c}4,61 \mathrm{e}-7 \\
(1,81 \mathrm{e}-7)\end{array}$ & $\begin{array}{c}3,0424 \\
(0,0554)\end{array}$ & 0,928 & 384 \\
\hline \multirow{2}{*}{$\mathbf{R J}$} & $\begin{array}{c}8,94 \mathrm{e}-8 \\
(7,27 \mathrm{e}-8)\end{array}$ & $\begin{array}{c}3,2764 \\
(0,1161)\end{array}$ & 0,946 & 75 \\
\hline SPF & $\begin{array}{c}3,93 \mathrm{e}-7 \\
(1,34 \mathrm{e}-7)\end{array}$ & $\begin{array}{c}3,065 \\
(0,048)\end{array}$ & 0,933 & 459 \\
\hline SPM & $\begin{array}{c}3,03 \mathrm{e}-8 \\
(8,33 \mathrm{e}-9)\end{array}$ & $\begin{array}{c}3,4250 \\
(0,0386)\end{array}$ & 0,974 & 433 \\
\hline SP & $\begin{array}{c}5,89 \mathrm{e}-8 \\
(1,86 \mathrm{e}-8)\end{array}$ & $\begin{array}{c}3,3325 \\
(0,0449)\end{array}$ & 0,969 & 451 \\
\hline SCF & $\begin{array}{c}4,01 \mathrm{e}-8 \\
(6,09 \mathrm{e}-9)\end{array}$ & $\begin{array}{c}3,386 \\
(0,021)\end{array}$ & 0,978 & 4139 \\
\hline SCM & $\begin{array}{c}2,52 \mathrm{e}-8 \\
(7,27 \mathrm{e}-9)\end{array}$ & $\begin{array}{c}3,4588 \\
(0,041)\end{array}$ & 0,933 & 138 \\
\hline SC & $\begin{array}{c}7,07 \mathrm{e}-8 \\
(3,62 \mathrm{e}-8)\end{array}$ & $\begin{array}{c}3,3097 \\
(0,0738)\end{array}$ & 0,944 & 707 \\
\hline
\end{tabular}

Tabela 16: Níveis de significância $(\mathrm{P})$ do teste de $\chi^{2}$ da razão de verossimilhança máxima para as diversas hipóteses de comparação entre as curvas resultantes do modelo potencial entre peso total e comprimento total. Curvas: hipótese de curvas coincidentes; a: hipótese de igualdade de interceptos; b: hipótese de igualdade de inclinações. *Diferenças significativas com $\mathrm{P}<0,05$.

\begin{tabular}{|c|c|c|c|}
\cline { 2 - 4 } \multicolumn{1}{c|}{} & Curvas & a & b \\
\hline RJF x RJM & 0,3377 & & $0^{*}$ \\
\hline SPF x SPM & $0,0017^{*}$ & $0^{*}$ & \\
\hline SCF X SCM & 0,3387 & & $0^{*}$ \\
\hline RJ x SPF & $1,37 \mathrm{e}-19^{*}$ & $0^{*}$ & $0^{*}$ \\
\hline RJ x SPM & $9,61 \mathrm{e}-10^{*}$ & $0^{*}$ & $0^{*}$ \\
\hline RJ x SC & $4,58 \mathrm{e}-28^{*}$ & $0^{*}$ & $7,29 \mathrm{e}-56^{*}$ \\
\hline SPF x SC & $4,42 \mathrm{e}-19^{*}$ & $1,82 \mathrm{e}-17^{*}$ & $0^{*}$ \\
\hline SPM x SC & $6,62 \mathrm{e}-14^{*}$ & $0^{*}$ & \\
\hline
\end{tabular}


Tabela 17: Número de exemplares por sexo de Trichiurus lepturus coletados mensalmente nos diferentes Estados.

Rio de Janeiro

\begin{tabular}{|c|c|cc|c|}
\hline Ano & Mês & F & M & \%Fem \\
\hline $\mathbf{2 0 0 2}$ & 2 & 22 & 3 & 88 \\
& 3 & 14 & 1 & 93 \\
& 4 & 35 & 3 & 92 \\
& 5 & 31 & 4 & 89 \\
& 6 & 22 & 2 & 92 \\
& 7 & 23 & 7 & 77 \\
& 8 & 33 & 11 & 75 \\
& 9 & 20 & 10 & 67 \\
& 10 & 28 & 10 & 74 \\
& 11 & 23 & 7 & 77 \\
& 12 & 18 & 6 & 75 \\
\hline 2003 & 1 & 23 & 2 & 92 \\
& 2 & 15 & & 100 \\
& 3 & 13 & 1 & 93 \\
& 4 & 14 & & 100 \\
& 5 & 25 & 5 & 83 \\
& 6 & 13 & & 100 \\
& 7 & 12 & 3 & 80 \\
\hline Total & & 384 & 75 & \\
& & \multicolumn{2}{|c}{}
\end{tabular}

São Paulo

\begin{tabular}{|c|c|ccc|c|}
\hline Ano & Mês & F & I & M & \%Fem \\
\hline $\mathbf{2 0 0 2}$ & 1 & 9 & & 33 & 21 \\
& 2 & 9 & & 23 & 28 \\
& 3 & 59 & 5 & 38 & 58 \\
& 4 & 22 & 3 & 20 & 49 \\
& 5 & 37 & 1 & 28 & 56 \\
& 6 & 14 & 4 & 19 & 38 \\
& 7 & 13 & 9 & 19 & 32 \\
& 8 & 19 & & 29 & 40 \\
& 9 & 25 & & 13 & 66 \\
& 10 & 27 & & 30 & 47 \\
& 11 & 34 & 21 & 23 & 44 \\
& 12 & 9 & & 13 & 41 \\
\hline 2003 & 1 & 14 & 1 & 23 & 37 \\
& 2 & 28 & 3 & 36 & 42 \\
& 3 & 26 & 2 & 37 & 40 \\
& 4 & 33 & & 22 & 60 \\
& 5 & 11 & & 22 & 33 \\
& 6 & 44 & & 23 & 66 \\
\hline Total & & 433 & 49 & 451 &
\end{tabular}

Santa Catarina

\begin{tabular}{|c|c|ccc|c|}
\hline Ano & Mês & F & I & M & \%Fem \\
\hline $\mathbf{2 0 0 2}$ & 1 & 38 & & 12 & 76 \\
& 2 & 35 & & 1 & 97 \\
& 3 & 40 & & 1 & 98 \\
& 4 & 34 & & 5 & 87 \\
& 5 & 11 & 17 & 21 & 22 \\
& 6 & 26 & & 4 & 87 \\
& 7 & 26 & & 16 & 62 \\
& 8 & 19 & & 12 & 61 \\
& 9 & 24 & & 9 & 73 \\
& 10 & 25 & & 4 & 86 \\
& 11 & 26 & 14 & 4 & 59 \\
& 12 & 27 & & 4 & 87 \\
\hline 2003 & 1 & 27 & & 15 & 64 \\
& 2 & 25 & 12 & 2 & 64 \\
& 3 & 36 & 1 & 8 & 80 \\
& 5 & 16 & & 16 & 50 \\
& 6 & 21 & & 4 & 84 \\
\hline Total & & 456 & 44 & 138 &
\end{tabular}


Tabela 18: Comprimentos totais e anais médios de primeira maturação gonadal $\left(\mathrm{L}_{50}\right)$ de $T$. lepturus em cada Estado analisado.

\begin{tabular}{|c|c|c|c|c|c|c|}
\cline { 2 - 7 } \multicolumn{1}{c|}{} & \multicolumn{2}{c|}{ Fêmeas } & \multicolumn{2}{c|}{ Machos } & \multicolumn{2}{c|}{ Agrupados } \\
\cline { 2 - 7 } \multicolumn{1}{c|}{} & Lt (mm) & La (mm) & Lt (mm) & La (mm) & Lt (mm) & La (mm) \\
\hline RJ & 670,85 & 241,83 & 650,00 & 229,60 & 671,55 & 227,21 \\
\hline SP & 666,88 & 234,63 & 540,76 & 183,64 & 602,64 & 207,35 \\
\hline SC & 647,33 & 227,13 & 526,28 & 191,77 & 601,11 & 203,72 \\
\hline
\end{tabular}

Tabela 19: Níveis de significância (P) do teste de $\chi^{2}$ da razão de verossimilhança máxima para as diversas hipóteses de comparação entre as curvas de freqüência relativa acumulada de fêmeas e machos adultos por classe de comprimento total $(\mathrm{mm})$. Curvas: hipótese de curvas coincidentes; L50: hipótese de igualdade de pontos de inflecção das curvas; r: hipótese de igualdade de coeficientes de curvatura. * Diferenças significativas com $\mathrm{P}<0,05$.

\begin{tabular}{|c|c|c|c|c|c|c|}
\cline { 2 - 7 } \multicolumn{1}{c|}{} & \multicolumn{3}{c|}{ Fêmeas } & \multicolumn{3}{c|}{ Machos } \\
\cline { 2 - 7 } \multicolumn{1}{c|}{ curvas } & L50 & r & curvas & L50 & r \\
\hline RJ x SP & 0,071 & & & $4,9 \mathrm{e}-21^{*}$ & $2,5 \mathrm{e}-21^{*}$ & $1,4 \mathrm{e}-15^{*}$ \\
\hline RJ x SC & $0,044^{*}$ & 0,1163 & 0,1370 & $8,5 \mathrm{e}-5^{*}$ & $1,2 \mathrm{e}-5^{*}$ & $0,0031^{*}$ \\
\hline SP x SC & $0,001^{*}$ & $0,0005^{*}$ & 0,051 & 0,876 & & \\
\hline
\end{tabular}


Tabela 20: Níveis de significância (P) do teste de $\chi^{2}$ da razão de verossimilhança máxima para as diversas hipóteses de comparação entre as curvas resultantes do modelo potencial entre fecundidade e as variáveis de peso total e comprimento total dos Estados de São Paulo e Santa Catarina. Curvas: hipótese de curvas coincidentes; a: hipótese de igualdade de interceptos; b: hipótese de igualdade de inclinações. * Diferenças significativas com $\mathrm{P}<0,05$.

\begin{tabular}{|c|c|c|c|c|c|c|}
\cline { 2 - 7 } \multicolumn{1}{c|}{} & \multicolumn{3}{c|}{ Fecundidade $x$ Peso Total } & \multicolumn{2}{c|}{ Fecundidade $x$ Comprimento Total } \\
\cline { 2 - 7 } & curvas & a & b & curvas & a & b \\
\hline SP $x$ SC & 0,057 & & & 0,278 & & \\
\hline
\end{tabular}

Tabela 21: Número analisado de otólitos de fêmeas (F) e machos (M) por classe de comprimento e bimestre de T. lepturus amostrados em Arraial do Cabo (RJ).

\begin{tabular}{|c|c|c|c|}
\hline Classe Lt $\mathbf{( m m})$ & $\mathbf{F}$ & $\mathbf{M}$ & Total \\
\hline 600 & 2 & 1 & 3 \\
650 & 3 & 2 & 5 \\
700 & 5 & 1 & 6 \\
750 & 1 & 2 & 3 \\
800 & 2 & 1 & 3 \\
850 & 3 & 2 & 5 \\
900 & 7 & 4 & 11 \\
950 & 4 & 6 & 10 \\
1000 & 4 & 4 & 8 \\
1050 & 9 & 6 & 15 \\
1100 & 6 & 6 & 12 \\
1150 & 2 & 3 & 5 \\
1200 & 4 & 3 & 7 \\
1250 & 8 & 1 & 9 \\
1300 & 7 & & 7 \\
1350 & 1 & & 1 \\
1400 & 1 & & 1 \\
\hline Total & 69 & 42 & 111 \\
\hline
\end{tabular}

\begin{tabular}{|c|c|c|c|}
\hline Bimestre & $\mathbf{F}$ & $\mathbf{M}$ & Total \\
\hline 1 & 13 & 5 & 18 \\
2 & 6 & 5 & 11 \\
3 & 19 & 9 & 28 \\
4 & 15 & 8 & 23 \\
5 & 6 & 7 & 13 \\
6 & 10 & 8 & 18 \\
\hline Total & 69 & 42 & 111 \\
\hline
\end{tabular}


Tabela 22: Número analisado de otólitos de fêmeas (F) e machos (M) por classe de comprimento e bimestre de T. lepturus amostrados no Guarujá (SP).

\begin{tabular}{|c|c|c|c|c|}
\hline Classe Lt (mm) & $F$ & I & $\mathbf{M}$ & Total \\
\hline 300 & & 3 & & 3 \\
\hline 350 & 1 & 5 & 1 & 7 \\
\hline 400 & 3 & 2 & 3 & 8 \\
\hline 450 & 4 & 6 & & 10 \\
\hline 500 & 2 & & 3 & 5 \\
\hline 550 & 3 & & & 3 \\
\hline 600 & 1 & & 2 & 3 \\
\hline 650 & 1 & & 2 & 3 \\
\hline 700 & & & 2 & 2 \\
\hline 750 & 2 & & 5 & 7 \\
\hline 800 & 3 & & 3 & 6 \\
\hline 850 & 4 & & 4 & 8 \\
\hline 900 & 2 & & 3 & 5 \\
\hline 950 & 3 & & 6 & 9 \\
\hline 1000 & 4 & & 8 & 12 \\
\hline 1050 & 6 & & 3 & 9 \\
\hline 1100 & 3 & & 7 & 10 \\
\hline 1150 & 6 & & 5 & 11 \\
\hline 1200 & 7 & & 6 & 13 \\
\hline 1250 & 4 & & 3 & 7 \\
\hline 1300 & 6 & & 1 & 7 \\
\hline 1350 & 3 & & & 3 \\
\hline 1400 & 3 & & & 3 \\
\hline 1450 & 2 & & & 2 \\
\hline Total & 73 & 16 & 67 & 156 \\
\hline
\end{tabular}

\begin{tabular}{|c|c|c|c|c|}
\hline Bimestre & $\mathbf{F}$ & $\mathbf{I}$ & $\mathbf{M}$ & Total \\
\hline 1 & 7 & & 9 & 16 \\
2 & 13 & 3 & 10 & 26 \\
3 & 15 & 3 & 16 & 34 \\
4 & 10 & 4 & 8 & 22 \\
5 & 13 & & 13 & 26 \\
6 & 15 & 6 & 11 & 32 \\
\hline Total & 73 & 16 & 67 & 156 \\
\hline
\end{tabular}


Tabela 23: Número analisado de otólitos de fêmeas (F) e machos (M) por classe de comprimento e bimestre de T. lepturus amostrados em Porto Belo (SC).

\begin{tabular}{|c|c|c|c|c|}
\hline Classe Lt $\mathbf{( m m})$ & $\mathbf{F}$ & $\mathbf{I}$ & $\mathbf{M}$ & Total \\
\hline 150 & & 1 & & 1 \\
200 & & 2 & & 2 \\
250 & & 4 & & 4 \\
300 & 1 & 2 & 1 & 4 \\
350 & 1 & 1 & & 2 \\
400 & & 3 & & 3 \\
450 & & 2 & 1 & 3 \\
500 & & 3 & 1 & 4 \\
550 & & & 2 & 2 \\
600 & 3 & & 3 & 6 \\
650 & 1 & & 5 & 6 \\
700 & 7 & & 3 & 10 \\
750 & 7 & & 5 & 12 \\
800 & 3 & & 7 & 10 \\
850 & 4 & & 2 & 6 \\
900 & 4 & & 7 & 11 \\
950 & 4 & & 4 & 8 \\
1000 & 10 & & 7 & 17 \\
1050 & 1 & & 5 & 6 \\
1100 & 8 & & 3 & 11 \\
1150 & 6 & & & 6 \\
1200 & 5 & & 4 & 9 \\
1250 & 5 & & & 5 \\
1300 & 6 & & & 6 \\
1400 & 2 & & & 2 \\
1550 & 1 & & & 1 \\
\hline Total & 79 & 18 & 60 & 157 \\
\hline
\end{tabular}

\begin{tabular}{|c|c|c|c|c|}
\hline Bimestre & $\mathbf{F}$ & $\mathbf{I}$ & $\mathbf{M}$ & Total \\
\hline 1 & 15 & 9 & 9 & 33 \\
2 & 17 & & 9 & 26 \\
3 & 14 & 5 & 22 & 41 \\
4 & 12 & & 11 & 23 \\
5 & 11 & & 5 & 16 \\
6 & 10 & 4 & 4 & 18 \\
\hline Total & 79 & 18 & 60 & 157 \\
\hline
\end{tabular}


Tabela 24: Descrição de amostras de comprimento (Lo $-\mathrm{mm}$ ), altura (Ho $-\mathrm{mm})$ e peso (Wo $-\mathrm{g})$ dos otólitos esquerdo (E) e direito (D) por sexo de T. lepturus da região de Arraial do Cabo (RJ). n - número da amostra; dp - desvio padrão; Min e Max - limites da amplitude dos dados; stg1 simetria estandartizada; $\operatorname{stg} 2$ - curtose estandartizada.

\begin{tabular}{|c|c|c|c|c|c|c|}
\cline { 2 - 7 } \multicolumn{1}{c|}{ Fêmeas } & LoE & LoD & HoE & HoD & WoE & WoD \\
\hline $\mathbf{n}$ & 69 & 69 & 69 & 69 & 69 & 69 \\
\hline Média & 6,58 & 6,56 & 2,54 & 2,49 & 0,019 & 0,019 \\
\hline $\mathbf{d p}$ & 1,16 & 1,15 & 0,43 & 0,43 & 0,008 & 0,008 \\
\hline Mediana & 6,60 & 6,65 & 2,60 & 2,55 & 0,019 & 0,018 \\
\hline Min & 4,35 & 4,40 & 1,70 & 1,55 & 0,005 & 0,005 \\
\hline Max & 9,00 & 9,10 & 3,60 & 3,45 & 0,043 & 0,046 \\
\hline stg1 & $-0,65$ & $-0,49$ & $-0,26$ & $-0,59$ & 1,226 & 1,752 \\
\hline stg2 & $-1,53$ & $-1,44$ & $-1,24$ & $-1,17$ & $-0,427$ & 0,483 \\
\hline
\end{tabular}

\begin{tabular}{|c|c|c|c|c|c|c|}
\cline { 2 - 7 } Machos & LoE & LoD & HoE & HoD & WoE & WoD \\
\hline n & 42 & 42 & 42 & 42 & 42 & 42 \\
\hline Média & 6,43 & 6,45 & 2,56 & 2,53 & 0,018 & 0,018 \\
\hline dp & 0,97 & 0,95 & 0,38 & 0,39 & 0,007 & 0,007 \\
\hline Mediana & 6,52 & 6,6 & 2,62 & 2,65 & 0,017 & 0,017 \\
\hline Min & 4,15 & 4,2 & 1,7 & 1,60 & 0,005 & 0,005 \\
\hline Max & 7,95 & 8,2 & 3,15 & 3,00 & 0,030 & 0,029 \\
\hline stg1 & $-1,432$ & $-1,487$ & $-1,408$ & $-1,762$ & 0,007 & $-0,080$ \\
\hline stg2 & $-0,459$ & $-0,345$ & $-0,751$ & $-0,601$ & $-1,346$ & $-1,463$ \\
\hline
\end{tabular}


Tabela 25: Descrição de amostras de comprimento (Lo $-\mathrm{mm}$ ), altura (Ho $-\mathrm{mm}$ ) e peso (Wo $-\mathrm{g}$ ) dos otólitos esquerdo (E) e direito (D) por sexo de T. lepturus da costa de São Paulo. $\mathrm{n}$ - número da amostra; dp - desvio padrão; Min e Max - limites da amplitude dos dados; stg1 - simetria estandartizada; $\operatorname{stg} 2$ - curtose estandartizada.

\begin{tabular}{|c|c|c|c|c|c|c|}
\cline { 2 - 7 } Fêmeas & LoE & LoD & HoE & HoD & WoE & WoD \\
\hline $\mathbf{n}$ & 105 & 105 & 105 & 105 & 105 & 105 \\
\hline Média & 6,23 & 6,24 & 2,45 & 2,41 & 0,017 & 0,017 \\
\hline $\mathbf{d p}$ & 1,71 & 1,71 & 0,62 & 0,63 & 0,011 & 0,011 \\
\hline Mediana & 6,30 & 6,30 & 2,45 & 2,4 & 0,015 & 0,016 \\
\hline Min & 3,00 & 3,05 & 1,20 & 1,15 & 0,002 & 0,002 \\
\hline Max & 9,90 & 9,90 & 3,65 & 3,70 & 0,050 & 0,050 \\
\hline stg1 & $-0,015$ & $-0,224$ & $-0,561$ & $-0,305$ & 2,384 & 2,226 \\
\hline stg2 & $-2,109$ & $-2,141$ & $-2,074$ & $-1,989$ & $-1,248$ & $-1,365$ \\
\hline
\end{tabular}

\begin{tabular}{|c|c|c|c|c|c|c|}
\cline { 2 - 7 } Machos & LoE & LoD & HoE & HoD & WoE & WoD \\
\hline $\mathbf{n}$ & 86 & 86 & 86 & 86 & 86 & 86 \\
\hline Média & 5,89 & 5,91 & 2,35 & 2,29 & 0,014 & 0,014 \\
\hline dp & 1,56 & 1,55 & 0,59 & 0,60 & 0,009 & 0,010 \\
\hline Mediana & 5,77 & 5,80 & 2,40 & 2,32 & 0,012 & 0,012 \\
\hline Min & 3,25 & 3,10 & 1,25 & 1,20 & 0,002 & 0,002 \\
\hline Max & 9,00 & 9,00 & 3,40 & 3,40 & 0,037 & 0,038 \\
\hline stg1 & 0,281 & 0,190 & $-0,769$ & $-0,470$ & 2,146 & 2,259 \\
\hline stg2 & $-1,811$ & $-1,839$ & $-1,938$ & $-1,989$ & $-1,387$ & $-1,257$ \\
\hline
\end{tabular}


Tabela 26: Descrição de amostras de comprimento (Lo $-\mathrm{mm}$ ), altura (Ho $-\mathrm{mm}) \mathrm{e}$ peso (Wo $-\mathrm{g})$ dos otólitos esquerdo (E) e direito (D) por sexo de T. lepturus da região de Porto Belo (SC). n número da amostra; dp - desvio padrão; Min e Max - limites da amplitude dos dados; stg1 simetria estandartizada; stg2 - curtose estandartizada.

\begin{tabular}{|c|c|c|c|c|c|c|}
\cline { 2 - 7 } \multicolumn{1}{c|}{ Fêmeas } & LoE & LoD & HoE & HoD & WoE & WoD \\
\hline $\mathbf{n}$ & 79 & 79 & 79 & 79 & 79 & 79 \\
\hline Média & 6,50 & 6,51 & 2,53 & 2,48 & 0,018 & 0,018 \\
\hline dp & 1,44 & 1,43 & 0,52 & 0,51 & 0,010 & 0,010 \\
\hline Mediana & 6,30 & 6,25 & 2,50 & 2,50 & 0,016 & 0,016 \\
\hline Min & 2,90 & 3,00 & 1,12 & 1,10 & 0,002 & 0,002 \\
\hline Max & 10,00 & 9,95 & 3,80 & 3,60 & 0,048 & 0,047 \\
\hline stg1 & $-0,101$ & $-0,094$ & $-0,665$ & $-0,820$ & 2,057 & 2,018 \\
\hline stg2 & $-0,862$ & $-0,851$ & $-0,103$ & $-0,424$ & $-0,687$ & $-0,803$ \\
\hline
\end{tabular}

\begin{tabular}{|c|c|c|c|c|c|c|}
\cline { 2 - 7 } \multicolumn{1}{c|}{ Machos } & LoE & LoD & HoE & HoD & WoE & WoD \\
\hline n & 58 & 58 & 58 & 58 & 58 & 58 \\
\hline Média & 5,96 & 5,97 & 2,35 & 2,28 & 0,014 & 0,014 \\
\hline dp & 1,15 & 1,16 & 0,45 & 0,44 & 0,007 & 0,007 \\
\hline Mediana & 5,92 & 5,92 & 2,30 & 2,25 & 0,013 & 0,013 \\
\hline Min & 3,60 & 3,60 & 1,40 & 1,35 & 0,001 & 0,004 \\
\hline Max & 8,10 & 8,30 & 3,30 & 3,10 & 0,032 & 0,033 \\
\hline stg1 & -0116 & 0,0054 & $-0,059$ & $-0,108$ & 1,293 & 1,817 \\
\hline stg2 & $-1,660$ & $-1,535$ & $-1,299$ & $-1,537$ & $-0,629$ & $-0,500$ \\
\hline
\end{tabular}


Tabela 27: Níveis de significância dos testes $t(t)$ ou Wilcoxon-Mann-Whitney (W) pareados para o comprimento (Lo), altura (Ho) e peso (Wo) dos otólitos direito e esquerdo de fêmeas e machos de T. lepturus. RJ - Rio de Janeiro; SP - São Paulo; SC - Santa Catarina. * Diferença significativa ao nível de significância de 5\%.

\begin{tabular}{|c|c|c|c|c|c|c|}
\cline { 2 - 7 } \multicolumn{1}{c|}{} & \multicolumn{3}{c|}{ Fêmeas } & \multicolumn{3}{c|}{ Machos } \\
\cline { 2 - 7 } \multicolumn{1}{c|}{ Lo } & Ho & Wo & Lo & Ho & Wo \\
\hline RJ & $\mathrm{t}=0,101$ & $\mathrm{t}=1,0 \mathrm{e}-11^{*}$ & $\mathrm{t}=0,429$ & $\mathrm{t}=0,318$ & $\mathrm{t}=0,051$ & $\mathrm{t}=0,860$ \\
\hline SP & $\mathrm{W}=0,512$ & $\mathrm{~W}=1,2 \mathrm{e}-4^{*}$ & $\mathrm{~W}=0,999$ & $\mathrm{t}=0,209$ & $\mathrm{t}=3,0 \mathrm{e}-6^{*}$ & $\mathrm{~W}=0,999$ \\
\hline SC & $\mathrm{t}=0,291$ & $\mathrm{t}=7,0 \mathrm{e}-8^{*}$ & $\mathrm{~W}=0,999$ & $\mathrm{t}=0,234$ & $\mathrm{t}=3,9 \mathrm{e}-7^{*}$ & $\mathrm{t}=0,038^{*}$ \\
\hline
\end{tabular}

Tabela 28: Parâmetros da relação linear $\left(y=a+b^{*} x\right)$ entre comprimento do otólito e comprimento total dos exemplares de T. lepturus por sexo obtidos para os diferentes Estados analisados e seus respectivos desvios padrão (parênteses). RJF e RJM - fêmeas e machos do Rio de Janeiro; SPF e SPM - fêmeas e machos de São Paulo; SCF e SCM - fêmeas e machos de Santa Catarina; $a$ - intercepto; $b$ - inclinação; $\mathrm{r}^{2}$ - coeficiente de determinação; $\mathrm{n}$ - número amostral.

\begin{tabular}{|c|c|c|c|c|}
\cline { 2 - 5 } \multicolumn{1}{c|}{} & $\mathbf{a}$ & $\mathbf{b}$ & $\mathbf{r}^{\mathbf{2}}$ & $\mathbf{n}$ \\
\hline \multirow{2}{*}{ RJF } & $\begin{array}{c}1,274 \\
(0,222)\end{array}$ & $\begin{array}{c}0,005 \\
(0,0002)\end{array}$ & 0,902 & 42 \\
\hline RJM & $\begin{array}{c}0,880 \\
(0,373)\end{array}$ & $\begin{array}{c}0,005 \\
(0,0003)\end{array}$ & 0,850 & 105 \\
\hline SPF & $\begin{array}{c}1,194 \\
(0,146)\end{array}$ & $\begin{array}{c}0,005 \\
(0,0001)\end{array}$ & 0,927 & 86 \\
\hline \multirow{2}{*}{ SCF } & $\begin{array}{c}0,897 \\
(0,138)\end{array}$ & $\begin{array}{c}0,006 \\
(0,0001)\end{array}$ & 0,944 & 79 \\
\hline SCM & $\begin{array}{c}0,823 \\
(0,183)\end{array}$ & $\begin{array}{c}0,006 \\
(0,0002)\end{array}$ & 0,930 & 58 \\
\hline
\end{tabular}


Tabela 29: Níveis de significância da análise de covariância (ANCOVA) das inclinações $(\mathrm{Pb}) \mathrm{e}$ interceptos $(\mathrm{Pa})$ das relações lineares entre comprimento do otólito e comprimento total, e respectivos parâmetros comuns. * Diferenças significativas com $\mathrm{P}<0,05$.

\begin{tabular}{|c|c|c|c|c|}
\cline { 2 - 5 } \multicolumn{1}{c|}{} & Pb & Pa & b comum & a comum \\
\hline RJF x RJM & 0,2463 & 0,1840 & 0,005 & 1,181 \\
\hline SPF x SPM & $0,0140^{*}$ & & & \\
\hline SCF X SCM & 0,3818 & $0,0110^{*}$ & & \\
\hline RJF x SPF & 0,5647 & 0,2081 & 0,005 & 0,196 \\
\hline RJF x SCF & $0,0320^{*}$ & & & 1,089 \\
\hline SPF x SCF & 0,0722 & 0,3637 & 0,005 & \\
\hline RJM x SPM & 0,5765 & $0,002^{*}$ & & \\
\hline RJM x SCM & 0,3670 & $0,0031^{*}$ & & 0,856 \\
\hline SPM x SCM & 0,5917 & 0,7742 & 0,006 & \\
\hline
\end{tabular}

Tabela 30: Parâmetros da relação linear $(y=a+b * x)$ entre altura do otólito e comprimento total dos exemplares de $T$. lepturus por sexo obtidos para os diferentes Estados analisados e seus respectivos desvios padrão (parênteses). RJF e RJM - fêmeas e machos do Rio de Janeiro; SPF e SPM - fêmeas e machos de São Paulo; SCF e SCM - fêmeas e machos de Santa Catarina; $a$ - intercepto; $b$ - inclinação; $r^{2}$ - coeficiente de determinação; $n$ - número amostral.

\begin{tabular}{|c|c|c|c|c|}
\cline { 2 - 5 } \multicolumn{1}{c|}{} & $\mathbf{a}$ & $\mathbf{b}$ & $\mathbf{r}^{\mathbf{2}}$ & $\mathbf{n}$ \\
\hline \multirow{2}{*}{ RJF } & $\begin{array}{c}0,571 \\
(0,098)\end{array}$ & $\begin{array}{c}0,002 \\
(9 \mathrm{e}-5)\end{array}$ & 0,864 & 42 \\
\hline SPF & $\begin{array}{c}0,317 \\
(0,120)\end{array}$ & $\begin{array}{c}0,002 \\
(0,0001)\end{array}$ & 0,900 & 105 \\
\hline SPM & $\begin{array}{c}0,584 \\
(0,036)\end{array}$ & $\begin{array}{c}0,002 \\
(3 \mathrm{e}-5)\end{array}$ & 0,966 & 86 \\
\hline SCF & $\begin{array}{c}0,455 \\
(0,045)\end{array}$ & $\begin{array}{c}0,002 \\
(5 \mathrm{e}-5)\end{array}$ & 0,957 & 79 \\
\hline SCM & $\begin{array}{c}0,480 \\
(0,065)\end{array}$ & $\begin{array}{c}0,002 \\
(6 \mathrm{e}-5)\end{array}$ & 0,932 & 58 \\
\hline
\end{tabular}


Tabela 31: Níveis de significância da análise de covariância (ANCOVA) das inclinações $(\mathrm{Pb}) \mathrm{e}$ interceptos $(\mathrm{Pa})$ das relações lineares entre altura do otólito e comprimento total, e respectivos parâmetros comuns. * Diferenças significativas com $\mathrm{P}<0,05$.

\begin{tabular}{|c|c|c|c|c|}
\cline { 2 - 5 } \multicolumn{1}{c|}{} & Pb & Pa & b comum & a comum \\
\hline RJF x RJM & $0,0350^{*}$ & & & \\
\hline SPF $~$ & & & \\
\hline SCF X SCM & $<0,0001^{*}$ & & & \\
\hline RJF x SPF & $0,012^{*}$ & & & \\
\hline RJF x SCF & 0,5180 & $0,0015^{*}$ & & \\
\hline SPF x SCF & 0,1305 & $0,0017^{*}$ & & \\
\hline RJM x SPM & 0,6901 & 0,8140 & 0,002 & \\
\hline RJM x SCM & 0,5296 & $0,0003 *$ & & \\
\hline SPM x SCM & 0,1540 & 0,2100 & 0,002 & 0,413 \\
\hline
\end{tabular}

Tabela 32: Parâmetros da relação potencial $\left(y=\mathrm{a}^{*} \mathrm{x}^{\mathrm{b}}\right)$ entre peso do otólito e comprimento total dos exemplares de T. lepturus por sexo obtidos para os diferentes Estados analisados e seus respectivos desvios padrão (parênteses). RJF e RJM - fêmeas e machos do Rio de Janeiro; SPF e SPM - fêmeas e machos de São Paulo; SCF e SCM - fêmeas e machos de Santa Catarina; $a$ - intercepto; $b$ - inclinação; $r^{2}$ - coeficiente de determinação; $n$ - número amostral.

\begin{tabular}{|c|c|c|c|c|}
\cline { 2 - 5 } \multicolumn{1}{c|}{} & $\mathbf{a}$ & $\mathbf{b}$ & $\mathbf{r}^{\mathbf{2}}$ & $\mathbf{n}$ \\
\hline \multirow{2}{*}{ RJF } & $\begin{array}{c}9,74 \mathrm{e}-10 \\
(8,47 \mathrm{e}-10)\end{array}$ & $\begin{array}{c}2,399 \\
(0,123)\end{array}$ & 0,982 & 69 \\
\hline RJM & $\begin{array}{c}1,58 \mathrm{e}-10 \\
(1,57 \mathrm{e}-10)\end{array}$ & $\begin{array}{c}2,676 \\
(0,178)\end{array}$ & 0,897 & 40 \\
\hline SPF & $\begin{array}{c}1,96 \mathrm{e}-9 \\
(1,19 \mathrm{e}-9)\end{array}$ & $\begin{array}{c}2,302 \\
(0,085)\end{array}$ & 0,979 & 86 \\
\hline SCF & $\begin{array}{c}9,85 \mathrm{e}-10 \\
(6,71 \mathrm{e}-10)\end{array}$ & $\begin{array}{c}2,417 \\
(0,097)\end{array}$ & 0,981 & 79 \\
\hline SCM & $\begin{array}{c}1,48 \mathrm{e}-9 \\
(8,5 \mathrm{e}-10)\end{array}$ & $\begin{array}{c}2,348 \\
(0,081)\end{array}$ & 0,986 & 58 \\
\hline
\end{tabular}


Tabela 33: Níveis de significância (P) do teste de $\chi^{2}$ da razão de verossimilhança máxima para as diversas hipóteses de comparação entre as curvas resultantes do modelo potencial entre peso do otólito e comprimento total. Curvas: hipótese de curvas coincidentes; a: hipótese de igualdade de interceptos; b: hipótese de igualdade de inclinações. * Diferenças significativas com $\mathrm{P}<0,05$.

\begin{tabular}{|c|c|c|c|}
\cline { 2 - 4 } \multicolumn{1}{c|}{} & curvas & a & b \\
\hline RJF x RJM & $1,63 \mathrm{e}-6^{*}$ & $0^{*}$ & $0^{*}$ \\
\hline SPF x SPM & $1,54 \mathrm{e}-9^{*}$ & $0^{*}$ & $0^{*}$ \\
\hline SCF X SCM & 0,074 & & \\
\hline RJF x SPF & 0,4468 & & $0^{*}$ \\
\hline RJF x SCF & $0,0006^{*}$ & $0^{*}$ & $0^{*}$ \\
\hline SPF $\times$ SCF & $0,0129^{*}$ & $0^{*}$ & $0^{*}$ \\
\hline RJM x SPM & $0,027^{*}$ & $0^{*}$ & $0^{*}$ \\
\hline RJM $\times$ SCM & $0,0007^{*}$ & $0^{*}$ & \\
\hline SPM x SCM & 0,976 & & \\
\hline
\end{tabular}

Tabela 34: Número de exemplares de $T$. lepturus obtido por número de anéis de crescimento nas secções dos otólitos, por sexo de cada Estado analisado.

\begin{tabular}{|c|cc|c|ccc|c|ccc|c|}
\cline { 2 - 11 } \multicolumn{1}{c|}{} & \multicolumn{3}{c|}{ RJ } & \multicolumn{4}{c|}{ SP } & \multicolumn{3}{c|}{ SC } \\
\hline No. Anéis & $\mathbf{F}$ & $\mathbf{M}$ & Total & $\mathbf{F}$ & $\mathbf{I}$ & $\mathbf{M}$ & Total & $\mathbf{F}$ & $\mathbf{I}$ & $\mathbf{M}$ & Total \\
\hline 0 & & & & 9 & 16 & 6 & 31 & 2 & 18 & 5 & 25 \\
1 & 8 & 3 & 11 & 7 & & 5 & 12 & 13 & & 15 & 28 \\
2 & 9 & 8 & 17 & 9 & & 8 & 17 & 16 & & 6 & 22 \\
3 & 8 & 7 & 15 & 6 & & 8 & 14 & 7 & & 19 & 26 \\
4 & 13 & 5 & 18 & 15 & & 10 & 25 & 14 & & 11 & 25 \\
5 & 21 & 14 & 35 & 9 & & 16 & 25 & 14 & & 3 & 17 \\
6 & 4 & 5 & 9 & 10 & & 8 & 18 & 10 & & 1 & 11 \\
7 & 6 & & 6 & 8 & & 6 & 14 & 2 & & & 2 \\
8 & & & & & & & & 1 & & & 1 \\
\hline Total & 69 & 42 & 111 & 73 & 16 & 67 & 156 & 79 & 18 & 60 & 157 \\
\hline
\end{tabular}


Tabela 35: Descrição de amostras dos resíduos dos modelos linear (Lin), potencial (Pot) e logístico (Log) entre comprimento total $(\mathrm{mm})$ e raio do otólito $(\mathrm{mm})$ por sexo de T. lepturus da região de Arraial do Cabo (RJ). n - número da amostra; dp - desvio padrão; Min e Max - limites da amplitude dos dados; stg1 - simetria estandartizada; stg2 - curtose estandartizada.

\begin{tabular}{|c|c|c|c|c|c|c|}
\cline { 2 - 7 } \multicolumn{1}{c|}{} & FemLin & FemPot & FemLog & MacLin & MacPot & MacLog \\
\hline $\mathbf{n}$ & 69 & 69 & 69 & 42 & 42 & 42 \\
\hline Média & $-2,90 \mathrm{e}-7$ & $-0,56$ & 0,15 & $-4,76 \mathrm{e}-7$ & $-0,11$ & $-0,01$ \\
\hline $\mathbf{d p}$ & 93,10 & 94,23 & 89,28 & 66,53 & 66,75 & 66,13 \\
\hline Mediana & 2,29 & 2,81 & $-6,60$ & 9,57 & 10,26 & 2,03 \\
\hline Min & $-161,34$ & $-157,93$ & $-177,86$ & $-126,35$ & $-125,96$ & $-130,08$ \\
\hline Max & 235,53 & 238,76 & 215,97 & 108,31 & 107,61 & 112,02 \\
\hline stg1 & 1,105 & 1,157 & $\underline{0,658}$ & $-0,544$ & $-0,519$ & $\underline{-0,514}$ \\
\hline stg2 & $-0,801$ & $-0,745$ & $\underline{-0,611}$ & $-1,240$ & $-1,263$ & $\underline{-1,154}$ \\
\hline
\end{tabular}

Tabela 36: Descrição de amostras dos resíduos dos modelos linear (Lin), potencial (Pot) e logístico (Log) entre comprimento total $(\mathrm{mm})$ e raio do otólito $(\mathrm{mm})$ por sexo de T. lepturus da costa de São Paulo. $\mathrm{n}$ - número da amostra; dp - desvio padrão; Min e Max - limites da amplitude dos dados; stg1 - simetria estandartizada; stg2 - curtose estandartizada.

\begin{tabular}{|c|c|c|c|c|c|c|}
\cline { 2 - 7 } \multicolumn{1}{c|}{} & FemLin & FemPot & FemLog & MacLin & MacPot & MacLog \\
\hline $\mathbf{n}$ & 73 & 73 & 73 & 67 & 67 & 67 \\
\hline Média & $1,37 \mathrm{e}-7$ & $-1,80$ & 0,38 & $1,49 \mathrm{e}-7$ & $-1,12$ & 0,19 \\
\hline $\mathbf{d p}$ & 108,75 & 111,49 & 102,89 & 103,34 & 104,26 & 98,71 \\
\hline Mediana & $-14,80$ & $-26,07$ & $-10,71$ & $-18,83$ & $-25,32$ & $-4,34$ \\
\hline Min & $-238,40$ & $-250,32$ & $-224,14$ & $-213,56$ & $-211,09$ & $-223,27$ \\
\hline Max & 255,15 & 260,23 & 235,47 & 315,07 & 315,11 & 297,57 \\
\hline stg1 & 1,270 & 1,526 & $\underline{0,591}$ & 2,576 & 2,686 & $\underline{2,361}$ \\
\hline stg2 & $-0,228$ & $-0,255$ & $\underline{-0,591}$ & 1,457 & 1,332 & $\underline{1,489}$ \\
\hline
\end{tabular}


Tabela 37: Descrição de amostras dos resíduos dos modelos linear (Lin), potencial (Pot) e logístico (Log) entre comprimento total $(\mathrm{mm})$ e raio do otólito $(\mathrm{mm})$ por sexo de T. lepturus da região de Porto Belo (SC). n - número da amostra; dp - desvio padrão; Min e Max - limites da amplitude dos dados; stg1 - simetria estandartizada; stg2 - curtose estandartizada.

\begin{tabular}{|c|c|c|c|c|c|c|}
\cline { 2 - 7 } \multicolumn{1}{c|}{} & FemLin & FemPot & FemLog & MacLin & MacPot & MacLog \\
\hline $\mathbf{n}$ & 79 & 79 & 79 & 60 & 60 & 60 \\
\hline Média & $-1,26 \mathrm{e}-7$ & 9,91 & 0,31 & $-6,67 \mathrm{e}-7$ & $-0,04$ & $-0,13$ \\
\hline $\mathbf{d p}$ & 85,870 & 89,04 & 82,25 & 68,18 & 68,12 & 68,67 \\
\hline Mediana & $-7,86$ & 1,28 & $-5,24$ & 0,22 & 2,63 & 2,95 \\
\hline Min & $-191,61$ & $-168,08$ & $-203,74$ & $-131,40$ & $-128,48$ & $-129,82$ \\
\hline Max & 216,41 & 231,22 & 197,47 & 184,18 & 183,58 & 181,90 \\
\hline stg1 & 0,770 & 0,894 & $\underline{0,292}$ & 1,127 & 1,232 & $\underline{1,111}$ \\
\hline stg2 & $-0,163$ & $-0,433$ & $\underline{-0,086}$ & 0,200 & 0,129 & $\underline{-0,058}$ \\
\hline
\end{tabular}

Tabela 38: Parâmetros das curvas do modelo logístico $\left(\mathrm{y}=\left(\mathrm{a} / 1+\mathrm{b} * \mathrm{c}^{\mathrm{x}}\right)\right.$ entre comprimento total e raio do otólito dos exemplares de T. lepturus por sexo e agrupados obtidos para os diferentes Estados analisados e seus respectivos desvios padrão (parênteses). RJF, RJM e RJ - fêmeas, machas e agrupadas do Rio de Janeiro; SPF, SPM e SP - fêmeas, machos e agrupados de São Paulo; SCF, SCM e SC - fêmeas, machos e agrupados de Santa Catarina; a - intercepto; b inclinação; $\mathrm{r}^{2}$ - coeficiente de determinação; $\mathrm{n}$ - número amostral.

\begin{tabular}{|c|c|c|c|c|c|}
\hline & $\mathbf{a}$ & b & c & $\mathbf{r}^{2}$ & $\mathrm{n}$ \\
\hline RJF & $\begin{array}{l}1561,38 \\
(131,70)\end{array}$ & $\begin{array}{c}26,28 \\
(12,19)\end{array}$ & $\begin{array}{c}0,069 \\
(0,033)\end{array}$ & 0,828 & 69 \\
\hline RJM & $\begin{array}{l}1519,99 \\
(294,77)\end{array}$ & $\begin{array}{c}15,82 \\
(10,64)\end{array}$ & $\begin{array}{c}0,098 \\
(0,083)\end{array}$ & 0,836 & 42 \\
\hline RJ & $\begin{array}{l}1599,67 \\
(142,26)\end{array}$ & $\begin{array}{l}19,60 \\
(6,75)\end{array}$ & $\begin{array}{c}0,091 \\
(0,036)\end{array}$ & 0,822 & 111 \\
\hline SPF & $\begin{array}{c}1563,99 \\
(97,72)\end{array}$ & $\begin{array}{l}23,25 \\
(6,37)\end{array}$ & $\begin{array}{c}0,074 \\
(0,023)\end{array}$ & 0,890 & 73 \\
\hline SPM & $\begin{array}{l}1405,57 \\
(115,40)\end{array}$ & $\begin{array}{l}15,98 \\
(5,09)\end{array}$ & $\begin{array}{c}0,094 \\
(0,036)\end{array}$ & 0,836 & 67 \\
\hline SP & $\begin{array}{c}1531,53 \\
(87,40)\end{array}$ & $\begin{array}{l}16,38 \\
(2,53)\end{array}$ & $\begin{array}{c}0,099 \\
(0,021)\end{array}$ & 0,880 & 156 \\
\hline SCF & $\begin{array}{l}1628,66 \\
(108,33)\end{array}$ & $\begin{array}{l}22,81 \\
(6,30)\end{array}$ & $\begin{array}{c}0,084 \\
(0,026)\end{array}$ & 0,889 & 79 \\
\hline SCM & $\begin{array}{l}1859,21 \\
(555,70)\end{array}$ & $\begin{array}{l}11,76 \\
(1,51)\end{array}$ & $\begin{array}{c}0,180 \\
(0,081)\end{array}$ & 0,879 & 60 \\
\hline SC & $\begin{array}{l}1777,01 \\
(109,30)\end{array}$ & $\begin{array}{c}17,04 \\
(1,61)\end{array}$ & $\begin{array}{c}0,125 \\
(0,018)\end{array}$ & 0,928 & 156 \\
\hline
\end{tabular}


Tabela 39: Comprimento total médio por classe etária para os conjuntos OtolMed (otólitos) e RetroMed (retrocalculados) por sexo e agrupados de T. lepturus da região de Arraial do Cabo (RJ) (n número de exemplares por classe etária; Ltmed - comprimento médio.

\section{FÊMEAS}

\begin{tabular}{|c|c|c|c|c|c|c|c|c|c|}
\hline Idade & $\mathrm{n}$ & OtolMed & 1 & 2 & 3 & 4 & 5 & 6 & 7 \\
\hline 1 & 8 & 681.20 & 582.73 & & & & & & \\
\hline 2 & 9 & 820.98 & 557.77 & 751.61 & & & & & \\
\hline 3 & 8 & 966.20 & 591.49 & 759.76 & 902.09 & & & & \\
\hline 4 & 13 & 1060.07 & 581.93 & 759.14 & 896.2 & 995.04 & & & \\
\hline 5 & 21 & 1182.99 & 583.14 & 752.32 & 895.08 & 1017.56 & 1121.01 & & \\
\hline 6 & 4 & 1277.70 & 590.28 & 780.41 & 914.22 & 1026.10 & 1134.37 & 1232.01 & \\
\hline 7 & 6 & 1342.43 & 564.93 & 736.20 & 889.04 & 1022.66 & 1148.21 & 1238.14 & 1300.55 \\
\hline \multicolumn{3}{|c|}{ RetroMed } & 579.35 & 754.90 & 897.21 & 1012.38 & 1128.00 & 1235.69 & 1300.55 \\
\hline
\end{tabular}

\section{MACHOS}

\begin{tabular}{|c|c|c|c|c|c|c|c|c|}
\hline Idade & $\mathbf{n}$ & OtolMed & 1 & 2 & 3 & 4 & 5 & 6 \\
\hline 1 & 3 & 668.00 & 607.85 & & & & & \\
\hline 2 & 8 & 842.30 & 610.93 & 767.18 & & & & \\
\hline 3 & 7 & 954.08 & 638.95 & 789.37 & 906.04 & & & \\
\hline 4 & 5 & 1035.57 & 609.69 & 765.56 & 884.57 & 970.58 & & \\
\hline 5 & 14 & 1124.85 & 623.29 & 761.11 & 885.03 & 989.77 & 1070.14 & \\
\hline 6 & 5 & 1180.60 & 627.32 & 784.45 & 895.69 & 989.76 & 1066.82 & 1142.16 \\
\hline \multicolumn{3}{|c|}{ RetroMed } & 621.30 & 770.99 & 891.42 & 985.77 & 1069.27 & 1142.16 \\
\hline
\end{tabular}

\section{AGRUPADOS}

\begin{tabular}{|c|c|c|c|c|c|c|c|c|c|}
\hline Idade & $\mathbf{n}$ & OtolMed & 1 & 2 & 3 & 4 & 5 & 6 & 7 \\
\hline 1 & 11 & 677.60 & 594.44 & & & & & & \\
\hline 2 & 17 & 831.01 & 584.86 & 758.33 & & & & & \\
\hline 3 & 15 & 960.60 & 615.67 & 773.64 & 903.63 & & & & \\
\hline 4 & 18 & 1053.26 & 600.85 & 765.67 & 893.99 & 987.97 & & & \\
\hline 5 & 35 & 1159.73 & 602.15 & 754.34 & 887.41 & 1002.76 & 1098.46 & & \\
\hline 6 & 9 & 1223.70 & 602.48 & 771.91 & 893.25 & 996.84 & 1090.12 & 1179.41 & \\
\hline 7 & 6 & 1342.43 & 589.91 & 748.88 & 891.24 & 1017.93 & 1140.45 & 1231.55 & 1297.06 \\
\hline \multicolumn{3}{|c|}{ RetroMed } & 599.72 & 761.20 & 892.68 & 999.40 & 1101.99 & 1200.26 & 1297.06 \\
\hline
\end{tabular}


Tabela 40: Comprimento total médio por classe etária para os conjuntos OtolMed (otólitos) e RetroMed (retrocalculados) por sexo e agrupados de T. lepturus da costa de São Paulo (n - número de exemplares por classe etária; Ltmed - comprimento médio.

\section{FÊMEAS}

\begin{tabular}{|c|c|c|c|c|c|c|c|c|c|}
\hline Idade & $n$ & OtolMed & 1 & 2 & 3 & 4 & 5 & 6 & 7 \\
\hline 0 & 9 & 453.39 & & & & & & & \\
\hline 1 & 7 & 630.20 & 538.08 & & & & & & \\
\hline 2 & 9 & 855.79 & 569.28 & 764.44 & & & & & \\
\hline 3 & 6 & 1035.22 & 636.32 & 814.95 & 960.83 & & & & \\
\hline 4 & 15 & 1101.09 & 589.12 & 749.45 & 903.84 & 1021.22 & & & \\
\hline 5 & 9 & 1194.02 & 542.64 & 754.76 & 927.41 & 1049.11 & 1144.33 & & \\
\hline 6 & 10 & 1313.70 & 601.61 & 822.49 & 973.20 & 1096.72 & 1188.46 & 1265.10 & \\
\hline 7 & 8 & 1382.1 & 601.65 & 784.01 & 976.15 & 1111.52 & 1221.54 & 1314.23 & 1363.17 \\
\hline \multicolumn{3}{|c|}{ RetroMed } & 582.15 & 777.21 & 941.89 & 1062.37 & 1183.55 & 1286.94 & 1363.17 \\
\hline
\end{tabular}

\section{MACHOS}

\begin{tabular}{|c|c|c|c|c|c|c|c|c|c|}
\hline Idade & $\bar{n}$ & OtolMed & 1 & 2 & 3 & 4 & 5 & 6 & 7 \\
\hline 0 & 6 & 443.67 & & & & & & & \\
\hline 1 & 5 & 645.34 & 566.03 & & & & & & \\
\hline 2 & 8 & 768.41 & 562.58 & 708.14 & & & & & \\
\hline 3 & 8 & 921.88 & 579.24 & 752.57 & 869.64 & & & & \\
\hline 4 & 10 & 981.92 & 545.22 & 715.46 & 840.79 & 935.86 & & & \\
\hline 5 & 13 & 1090.96 & 562.15 & 737.80 & 879.38 & 978.66 & 1047.75 & & \\
\hline 6 & 9 & 1209.33 & 641.68 & 795.80 & 929.81 & 1037.51 & 1114.73 & 1171.96 & \\
\hline 7 & 8 & 1152.29 & 545.96 & 706.87 & 837.62 & 932.66 & 1021.07 & 1078.44 & 1130.43 \\
\hline \multicolumn{3}{|c|}{ RetroMed } & 571.60 & 736.59 & 872.21 & 972.01 & 1060.73 & 1127.95 & 1130.43 \\
\hline
\end{tabular}

\section{AGRUPADOS}

\begin{tabular}{|c|c|c|c|c|c|c|c|c|c|}
\hline Idade & $\mathbf{n}$ & OtolMed & 1 & 2 & 3 & 4 & 5 & 6 & 7 \\
\hline 0 & 31 & 428.67 & & & & & & & \\
\hline 1 & 12 & 636.51 & 555.25 & & & & & & \\
\hline 2 & 17 & 814.67 & 578.57 & 741.75 & & & & & \\
\hline 3 & 14 & 970.45 & 614.12 & 784.02 & 909.98 & & & & \\
\hline 4 & 25 & 1053.42 & 591.18 & 748.19 & 884.44 & 989.18 & & & \\
\hline 5 & 22 & 1133.12 & 564.26 & 748.20 & 898.51 & 1005.91 & 1086.08 & & \\
\hline 6 & 20 & 1275.00 & 640.53 & 819.21 & 958.61 & 1070.19 & 1156.64 & 1226.66 & \\
\hline 7 & 15 & 1253.07 & 579.37 & 744.78 & 897.88 & 1011.98 & 1108.73 & 1182.14 & 1232.24 \\
\hline \multicolumn{3}{|c|}{ RetroMed } & 590.33 & 763.78 & 908.94 & 1017.60 & 1116.80 & 1207.58 & 1232.24 \\
\hline
\end{tabular}


Tabela 41: Comprimento total médio por classe etária para os conjuntos OtolMed (otólitos) e RetroMed (retrocalculados) por sexo e agrupados de T. lepturus da região de Porto Belo (SC) (n número de exemplares por classe etária; Ltmed - comprimento médio

FÊMEAS

\begin{tabular}{|c|c|c|c|c|c|c|c|c|c|c|}
\hline Idade & $\mathbf{n}$ & OtolMed & 1 & 2 & 3 & 4 & 5 & 6 & 7 & 8 \\
\hline 0 & 2 & 355.5 & & & & & & & & \\
\hline 1 & 13 & 713.54 & 617.61 & & & & & & & \\
\hline 2 & 16 & 854.5 & 595.32 & 765.86 & & & & & & \\
\hline 3 & 7 & 963.91 & 573.13 & 769.46 & 895.30 & & & & & \\
\hline 4 & 14 & 1110.36 & 625.80 & 814.61 & 950.05 & 1054.06 & & & & \\
\hline 5 & 14 & 1167.36 & 585.68 & 764.43 & 899.01 & 1018.94 & 1113.33 & & & \\
\hline 6 & 10 & 1293.80 & 611.51 & 787.80 & 936.06 & 1053.95 & 1162.70 & 1245.13 & & \\
\hline 7 & 2 & 1389.85 & 588.73 & 773.29 & 923.93 & 1073.09 & 1212.00 & 1301.63 & 1377.98 & \\
\hline 8 & 1 & 1573.00 & 599.73 & 812.57 & 968.99 & 1076.17 & 1188.35 & 1291.63 & 1390.61 & 1463.61 \\
\hline \multicolumn{3}{|c|}{ RetroMed } & 602.84 & 780.99 & 923.57 & 1043.51 & 1141.7 & 1257.4 & 1382.19 & 1463.61 \\
\hline
\end{tabular}

MACHOS

\begin{tabular}{|c|c|c|c|c|c|c|c|c|}
\hline Idade & $\mathbf{n}$ & OtolMed & 1 & 2 & 3 & 4 & 5 & 6 \\
\hline 0 & 5 & 497.6 & & & & & & \\
\hline 1 & 15 & 712.00 & 633.77 & & & & & \\
\hline 2 & 6 & 817.67 & 612.04 & 754.70 & & & & \\
\hline 3 & 19 & 956.53 & 625.36 & 769.26 & 874.11 & & & \\
\hline 4 & 11 & 1044.54 & 623.99 & 765.22 & 876.06 & 978.92 & & \\
\hline 5 & 3 & 1185.67 & 744.44 & 874.88 & 972.87 & 1071.92 & 1150.26 & \\
\hline 6 & 1 & 1212.00 & 643.97 & 779.92 & 882.93 & 1003.28 & 1059.73 & 1174.84 \\
\hline \multicolumn{3}{|c|}{ RetroMed } & 632.76 & 774.15 & 883.72 & 999.15 & 1127.63 & 1174.84 \\
\hline
\end{tabular}

\section{AGRUPADOS}

\begin{tabular}{|c|c|c|c|c|c|c|c|c|c|c|}
\hline Idade & $\mathbf{n}$ & OtolMed & 1 & 2 & 3 & 4 & 5 & 6 & 7 & 8 \\
\hline 0 & 25 & 392.24 & & & & & & & & \\
\hline 1 & 28 & 712.71 & 623.19 & & & & & & & \\
\hline 2 & 22 & 844.45 & 605.54 & 763.90 & & & & & & \\
\hline 3 & 26 & 958.51 & 587.72 & 755.32 & 873.78 & & & & & \\
\hline 4 & 25 & 1081.40 & 618.17 & 785.15 & 911.45 & 1018.33 & & & & \\
\hline 5 & 17 & 1170.59 & 621.52 & 781.90 & 905.38 & 1021.42 & 1116.33 & & & \\
\hline 6 & 11 & 1286.36 & 623.54 & 782.53 & 918.64 & 1034.64 & 1141.09 & 1232.92 & & \\
\hline 7 & 2 & 1389.85 & 601.95 & 767.13 & 905.26 & 1047.99 & 1189.43 & 1287.06 & 1375.59 & \\
\hline 8 & 1 & 1573.00 & 590.65 & 774.68 & 914.04 & 1013.40 & 1122.30 & 1228.67 & 1338.25 & 1425.67 \\
\hline \multicolumn{3}{|c|}{ RetroMed } & 611.56 & 771.94 & 899.09 & 1023.44 & 1130.02 & 1240.35 & 1363.15 & 1425.67 \\
\hline
\end{tabular}


Tabela 42: Parâmetros do modelo de crescimento de von Bertalanffy estimados para os conjuntos OtolTot, OtolMed, RetroTot e RetroMed, e seus respectivos desvios padrão (parênteses), coeficientes de determinação $\left(\mathrm{r}^{2}\right)$, número amostral $(\mathrm{n})$, índices de performance de crescimento $(\phi ')$ e pesos assintóticos $\left(\mathrm{W}_{\mathrm{oo}}\right)$, dos exemplares de T. lepturus da região de Arraial do Cabo (RJ).

\begin{tabular}{|c|c|c|c|c|c|c|c|c|}
\hline & & $\mathbf{L}_{\mathbf{0 0}}$ & $\mathbf{k}$ & $\mathbf{t}_{\mathbf{0}}$ & $\mathbf{r}^{2}$ & $\mathbf{n}$ & $\phi$ & $\mathbf{W}_{\text {oo }}$ \\
\hline \multirow{4}{*}{$\underset{\Xi}{\overparen{d}}$} & OtolTot & $\begin{array}{l}2010,90 \\
(475,46)\end{array}$ & $\begin{array}{c}0,117 \\
(0,057)\end{array}$ & $\begin{array}{l}-2,517 \\
(0,813)\end{array}$ & 0,858 & 69 & 5,67 & 5170.48 \\
\hline & OtolMed & $\begin{array}{c}1981,55 \\
(165,77)\end{array}$ & $\begin{array}{c}0,120 \\
(0,022)\end{array}$ & $\begin{array}{l}-2,481 \\
(0,312)\end{array}$ & 0,999 & 7 & 5,67 & 4944.29 \\
\hline & RetroTot & $\begin{array}{c}1807,42 \\
(157,71)\end{array}$ & $\begin{array}{c}0,148 \\
(0,026)\end{array}$ & $\begin{array}{l}-1,629 \\
(0,215)\end{array}$ & 0,902 & 273 & 5,68 & 3737.42 \\
\hline & RetroMed & $\begin{array}{c}1828,18 \\
(87,70)\end{array}$ & $\begin{array}{c}0,145 \\
(0,015)\end{array}$ & $\begin{array}{l}-1,641 \\
(0,158)\end{array}$ & 0,999 & 7 & 5,61 & 3869.56 \\
\hline \multirow{4}{*}{ 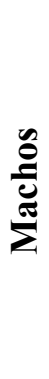 } & OtolTot & $\begin{array}{c}1373,54 \\
(152,02)\end{array}$ & $\begin{array}{c}0,255 \\
(0,103)\end{array}$ & $\begin{array}{c}-1,662 \\
(0,809)\end{array}$ & 0,849 & 42 & 5,68 & 1706.14 \\
\hline & OtolMed & $\begin{array}{c}1369,43 \\
(54,16)\end{array}$ & $\begin{array}{c}0,258 \\
(0,036)\end{array}$ & $\begin{array}{l}-1,618 \\
(0,256)\end{array}$ & 0,998 & 6 & 5,68 & 1689.47 \\
\hline & RetroTot & $\begin{array}{c}1431,82 \\
(109,47)\end{array}$ & $\begin{array}{c}0,201 \\
(0,004)\end{array}$ & $\begin{array}{c}-1,832 \\
(0,301)\end{array}$ & 0,908 & 160 & 5,61 & 1954.99 \\
\hline & RetroMed & $\begin{array}{c}1466,37 \\
(31,53)\end{array}$ & $\begin{array}{c}0,190 \\
(0,011)\end{array}$ & $\begin{array}{l}-1,914 \\
(0,100)\end{array}$ & 1,000 & 6 & 5,61 & 2113.84 \\
\hline
\end{tabular}

Tabela 43: Parâmetros do modelo de crescimento de von Bertalanffy estimados para os conjuntos OtolTot, OtolMed, RetroTot e RetroMed, e seus respectivos desvios padrão (parênteses), coeficientes de determinação $\left(\mathrm{r}^{2}\right)$, número amostral $(\mathrm{n})$, índices de performance de crescimento $\left(\phi^{\prime}\right)$ e pesos assintóticos $\left(\mathrm{W}_{\mathrm{oo}}\right)$, dos exemplares de T. lepturus da costa de São Paulo.

\begin{tabular}{|c|c|c|c|c|c|c|c|c|}
\hline & & $\mathbf{L}_{\mathbf{0 0}}$ & $\mathbf{k}$ & $\mathbf{t}_{\mathbf{0}}$ & $\mathbf{r}^{2}$ & $\mathbf{n}$ & $\phi$ & $\mathbf{W}_{\text {oo }}$ \\
\hline \multirow{4}{*}{ 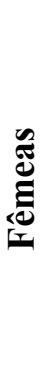 } & OtolTot & $\begin{array}{l}1740,33 \\
(136,35)\end{array}$ & $\begin{array}{c}0,181 \\
(0,033)\end{array}$ & $\begin{array}{c}-1,642 \\
(0,239)\end{array}$ & 0,934 & 73 & 5,74 & 3805.07 \\
\hline & OtolMed & $\begin{array}{l}1707,23 \\
(127,51)\end{array}$ & $\begin{array}{c}0,191 \\
(0,035)\end{array}$ & $\begin{array}{c}-1,571 \\
(0,241)\end{array}$ & 0,995 & 8 & 5,75 & 3562.86 \\
\hline & RetroTot & $\begin{array}{l}1786,32 \\
(116,86)\end{array}$ & $\begin{array}{c}0,173 \\
(0,025)\end{array}$ & $\begin{array}{l}-1,283 \\
(0,175)\end{array}$ & 0,912 & 264 & 5,74 & 4160.63 \\
\hline & RetroMed & $\begin{array}{l}1806,32 \\
(49,11)\end{array}$ & $\begin{array}{c}0,169 \\
(0,011)\end{array}$ & $\begin{array}{l}-1,308 \\
(0,093)\end{array}$ & 1,000 & 7 & 5,74 & 4322.36 \\
\hline \multirow{4}{*}{ 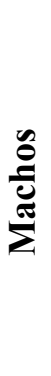 } & OtolTot & $\begin{array}{l}1566,96 \\
(171,65)\end{array}$ & $\begin{array}{c}0,171 \\
(0,045)\end{array}$ & $\begin{array}{l}-1,687 \\
(0,395)\end{array}$ & 0,890 & 67 & 5,62 & 2616.49 \\
\hline & OtolMed & $\begin{array}{l}1540,56 \\
(106,78)\end{array}$ & $\begin{array}{c}0,179 \\
(0,031)\end{array}$ & $\begin{array}{l}-1,935 \\
(0,234)\end{array}$ & 0,996 & 8 & 5,63 & 2472.45 \\
\hline & RetroTot & $\begin{array}{c}1468,31 \\
(97,27)\end{array}$ & $\begin{array}{c}0,200 \\
(0,033)\end{array}$ & $\begin{array}{c}-1,473 \\
(0,236)\end{array}$ & 0,867 & 255 & 5,63 & 2106.73 \\
\hline & RetroMed & $\begin{array}{c}1459,04 \\
(28,68)\end{array}$ & $\begin{array}{c}0,203 \\
(0,011)\end{array}$ & $\begin{array}{l}-1,448 \\
(0,095)\end{array}$ & 1,000 & 7 & 5,64 & 2062.73 \\
\hline
\end{tabular}


Tabela 44: Parâmetros do modelo de crescimento de von Bertalanffy estimados para os conjuntos OtolTot, OtolMed, RetroTot e RetroMed, e seus respectivos desvios padrão (parênteses), coeficientes de determinação $\left(\mathrm{r}^{2}\right)$, número amostral $(\mathrm{n})$, índices de performance de crescimento $(\phi ')$ e pesos assintóticos $\left(\mathrm{W}_{\mathrm{oo}}\right)$, dos exemplares de T. lepturus da região de Porto Belo (SC).

\begin{tabular}{|c|c|c|c|c|c|c|c|c|}
\hline & & $\mathbf{L}_{\mathbf{0 0}}$ & $\mathbf{k}$ & $\mathbf{t}_{\mathbf{0}}$ & $\mathbf{r}^{2}$ & $\mathbf{n}$ & $\phi '$ & $\mathbf{W}_{\text {oo }}$ \\
\hline \multirow{4}{*}{ 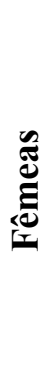 } & OtolTot & $\begin{array}{l}1831,53 \\
(251,36)\end{array}$ & $\begin{array}{c}0,150 \\
(0,047)\end{array}$ & $\begin{array}{l}-2,109 \\
(0,488)\end{array}$ & 0,887 & 79 & 5,70 & 4871.72 \\
\hline & OtolMed & $\begin{array}{l}2034,04 \\
(394,73)\end{array}$ & $\begin{array}{c}0,138 \\
(0,056)\end{array}$ & $\begin{array}{l}-1,696 \\
(0,532)\end{array}$ & 0,978 & 9 & 5,76 & 7001.89 \\
\hline & RetroTot & $\begin{array}{l}1917,68 \\
(169,52)\end{array}$ & $\begin{array}{c}0,136 \\
(0,023)\end{array}$ & $\begin{array}{l}-1,791 \\
(0,210)\end{array}$ & 0,917 & 274 & 5,70 & 5711.20 \\
\hline & RetroMed & $\begin{array}{l}2483,69 \\
(308,10)\end{array}$ & $\begin{array}{c}0,086 \\
(0,019)\end{array}$ & $\begin{array}{l}-2,295 \\
(0,320)\end{array}$ & 0,998 & 8 & 5,72 & 13970.90 \\
\hline \multirow{4}{*}{$\begin{array}{l}\text { on } \\
\frac{e}{e} \\
\sum\end{array}$} & OtolTot & $\begin{array}{l}1580,56 \\
(310,67)\end{array}$ & $\begin{array}{c}0,177 \\
(0,078)\end{array}$ & $\begin{array}{l}-1,866 \\
(0,583)\end{array}$ & 0,849 & 60 & 5,65 & 2733.97 \\
\hline & OtolMed & $\begin{array}{l}1607,89 \\
(192,44)\end{array}$ & $\begin{array}{c}0,176 \\
(0,050)\end{array}$ & $\begin{array}{l}-2,152 \\
(0,399)\end{array}$ & 0,993 & 7 & 5,76 & 2893.58 \\
\hline & RetroTot & $\begin{array}{l}2010,00 \\
(718,20)\end{array}$ & $\begin{array}{c}0,103 \\
(0,065)\end{array}$ & $\begin{array}{l}-2,661 \\
(0,699)\end{array}$ & 0,813 & 60 & 5,62 & 6057.28 \\
\hline & RetroMed & $\begin{array}{l}1850,70 \\
(405,78)\end{array}$ & $\begin{array}{c}0,122 \\
(0,054)\end{array}$ & $\begin{array}{c}-2,418 \\
(0,681)\end{array}$ & 0,995 & 6 & 5,62 & 4608.84 \\
\hline
\end{tabular}

Tabela 45: Níveis de significância (P) do teste de $\chi^{2}$ da razão de verossimilhança máxima para as diversas hipóteses de comparação entre as curvas resultantes do modelo de crescimento de von Bertalanffy dos conjuntos OtolTot e RetroTot por sexo de cada Estado. Curvas: hipótese de curvas coincidentes; $\mathrm{L}_{\mathrm{oo}}$ : hipótese de igualdade de comprimentos assintóticos; k: hipótese de igualdade de taxas de crescimento; $\mathrm{t}_{0}$ : hipótese de igualdade de idade teórica no comprimento zero; $\mathrm{L}_{\mathrm{oo}}-\mathrm{k}$ : hipótese de igualdade de $\mathrm{L}_{\mathrm{oo}}$ e $\mathrm{k} ; \mathrm{L}_{\mathrm{oo}}-\mathrm{t}_{0}$ : hipótese de igualdade de $\mathrm{L}_{\mathrm{oo}}$ e $\mathrm{t}_{0} ; \mathrm{k}-$

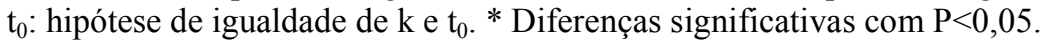

\begin{tabular}{|c|c|c|c|c|c|c|c|}
\cline { 2 - 8 } \multicolumn{1}{c|}{} & $\mathbf{c u r v a s}$ & $\mathbf{L}_{\mathbf{0 0}}$ & $\mathbf{k}$ & $\mathbf{t}_{\mathbf{0}}$ & $\mathbf{L}_{\mathbf{0 0}}-\mathbf{k}$ & $\mathbf{L}_{\mathbf{0 0}}-\mathbf{t}_{\mathbf{0}}$ & $\mathbf{k}-\mathbf{t}_{\mathbf{0}}$ \\
\hline $\mathbf{R J F}$ & $1,68 \mathrm{e}-8^{*}$ & 0,600 & 0,586 & 0,157 & 0,857 & $0,081^{*}$ & $0,013^{*}$ \\
\hline $\mathbf{R J M}$ & $3,85 \mathrm{e}-7^{*}$ & 0,747 & 0,591 & 0,828 & 0,409 & 0,944 & 0,346 \\
\hline $\mathbf{S P F}$ & $7,12 \mathrm{e}-6^{*}$ & 0,795 & 0,849 & 0,201 & 0,896 & $0,018^{*}$ & $0,002^{*}$ \\
\hline $\mathbf{S P M}$ & $0,005^{*}$ & 0,586 & 0,600 & 0,219 & 0,584 & 0,114 & $0,044^{*}$ \\
\hline $\mathbf{S C F}$ & $1,34 \mathrm{e}-9^{*}$ & 0,853 & 0,853 & 0,526 & 0,983 & 0,068 & $0,005^{*}$ \\
\hline SCM & $2,18 \mathrm{e}-6^{*}$ & 0,414 & 0,288 & 0,543 & 0,423 & 0,639 & 0,356 \\
\hline
\end{tabular}


Tabela 46: Parâmetros do modelo de crescimento de von Bertalanffy estimados para sexos agrupados do conjunto OtolTot de cada Estado, e seus respectivos desvios padrão (parênteses), coeficientes de determinação $\left(\mathrm{r}^{2}\right)$, número amostral $(\mathrm{n})$, índices de performance de crescimento $(\boldsymbol{\phi}$ ') e pesos assintóticos $\left(\mathrm{W}_{\mathrm{oo}}\right)$.

\begin{tabular}{|c|c|c|c|c|c|c|c|}
\cline { 2 - 7 } \multicolumn{1}{c|}{} & $\mathbf{L}_{\mathbf{0 o}}$ & $\mathbf{k}$ & $\mathbf{t}_{\mathbf{0}}$ & $\mathbf{r}^{\mathbf{2}}$ & $\mathbf{n}$ & $\boldsymbol{\phi}^{\prime}$ & $\mathbf{W}_{\mathbf{0 o}}$ \\
\hline \multirow{2}{*}{$\mathbf{R J}$} & $\begin{array}{c}1888,88 \\
(354,95)\end{array}$ & $\begin{array}{c}0,125 \\
(0,051)\end{array}$ & $\begin{array}{c}-2,603 \\
(0,721)\end{array}$ & 0,844 & 111 & 5,65 & 4325,29 \\
\hline \multirow{2}{*}{$\mathbf{S P}$} & $\begin{array}{c}1628,87 \\
(106,28)\end{array}$ & $\begin{array}{c}0,186 \\
(0,028)\end{array}$ & $\begin{array}{c}-1,654 \\
(0,179)\end{array}$ & 0,914 & 156 & 5,69 & 3012,23 \\
\hline \multirow{2}{*}{$\mathbf{S C}$} & $\begin{array}{c}1616,97 \\
(112,59)\end{array}$ & $\begin{array}{c}0,202 \\
(0,033)\end{array}$ & $\begin{array}{c}-1,599 \\
(0,186)\end{array}$ & 0,891 & 156 & 5,72 & 3144,13 \\
\hline
\end{tabular}

Tabela 47: Níveis de significância $(\mathrm{P})$ do teste de $\chi^{2}$ da razão de verossimilhança máxima para as diversas hipóteses de comparação entre as curvas resultantes do modelo de crescimento de von Bertalanffy do conjunto OtolTot entre sexos e agrupados de cada Estado. Curvas: hipótese de curvas coincidentes; $\mathrm{L}_{\mathrm{oo}}$ : hipótese de igualdade de comprimentos assintóticos; k: hipótese de igualdade de taxas de crescimento; $\mathrm{t}_{0}$ : hipótese de igualdade de idade teórica no comprimento zero; $\mathrm{L}_{\mathrm{oo}}-\mathrm{k}$ : hipótese de igualdade de $\mathrm{L}_{\mathrm{oo}}$ e $\mathrm{k} ; \mathrm{L}_{\mathrm{oo}}-\mathrm{t}_{0}$ : hipótese de igualdade de $\mathrm{L}_{\mathrm{oo}}$ e $\mathrm{t}_{0} ; \mathrm{k}-$ $\mathrm{t}_{0}$ : hipótese de igualdade de $\mathrm{k}$ e $\mathrm{t}_{0}$. * Diferenças significativas com $\mathrm{P}<0,05$.

\begin{tabular}{|c|c|c|c|c|c|c|c|}
\hline & curvas & $\mathbf{L}_{\mathbf{0 0}}$ & $\mathbf{k}$ & $\mathbf{t}_{\mathbf{0}}$ & $\mathbf{L}_{00}-k$ & $\mathbf{L}_{00}-\mathbf{t}_{0}$ & $\mathbf{k - t _ { 0 }}$ \\
\hline RJF x RJM & $0,018^{*}$ & 0,204 & 0,290 & 0,516 & $0,024 *$ & 0,070 & 0,123 \\
\hline SPF $\times$ SPM & $1,07 \mathrm{e}-10^{*}$ & 0,468 & 0,872 & 0,431 & $1,31 \mathrm{e}-6^{*}$ & $0,029^{*}$ & 0,326 \\
\hline SCF X SCM & 0,196 & & & & & & \\
\hline RJF x SPF & 0,101 & & & & & & \\
\hline RJF $x$ SCF & 0,454 & & & & & & \\
\hline SPF $\times$ SCF & 0,626 & & & & & & \\
\hline RJM x SPM & $0,008^{*}$ & 0,329 & 0,352 & 0,657 & 0,587 & 0,263 & 0,108 \\
\hline RJM x SCM & 0,849 & & & & & & \\
\hline SPM x SCM & $0,003 *$ & 0,970 & 0,952 & 0,689 & 0,782 & 0,725 & 0,422 \\
\hline RJ x SP & 0,288 & & & & & & \\
\hline $\mathbf{R J} \times \mathbf{S C}$ & 0,091 & & & & & & \\
\hline $\mathbf{S P} \times \mathbf{S C}$ & 0,086 & & & & & & \\
\hline
\end{tabular}


Tabela 48: Chave idade-comprimento por sexo e agrupados obtida para os exemplares da região de Arraial do cabo (RJ).

\begin{tabular}{|c|c|c|c|c|c|c|c|c|c|c|c|c|c|}
\hline \multirow{2}{*}{$\frac{\text { Idade }}{\text { Classes Lt }}$} & \multicolumn{7}{|c|}{ Fêmeas } & \multicolumn{6}{|c|}{ Machos } \\
\hline & 1 & 2 & 3 & 4 & 5 & 6 & 7 & 1 & 2 & 3 & 4 & 5 & 6 \\
\hline 600 & 100.0 & & & & & & & 100.0 & & & & & \\
\hline 650 & 100.0 & & & & & & & 100.0 & & & & & \\
\hline 700 & 40.0 & 60.0 & & & & & & & 100.0 & & & & \\
\hline 750 & & 100.0 & & & & & & & 100.0 & & & & \\
\hline 800 & 50.0 & 50.0 & & & & & & & 100.0 & & & & \\
\hline 850 & & 66.7 & 33.3 & & & & & & 50.0 & 50.0 & & & \\
\hline 900 & & 14.3 & 57.1 & 28.6 & & & & & 75.0 & 25.0 & & & \\
\hline 950 & & 25.0 & 25.0 & 25.0 & 25.0 & & & & & 66.7 & 33.3 & & \\
\hline 1000 & & & & 100.0 & & & & & & 25.0 & 50.0 & 25.0 & \\
\hline 1050 & & & 11.1 & 44.4 & 44.4 & & & & & & & 83.3 & 16.7 \\
\hline 1100 & & & 16.7 & 16.7 & 66.7 & & & & & & 16.7 & 66.7 & 16.7 \\
\hline 1150 & & & & & 100.0 & & & & & & & 100.0 & \\
\hline 1200 & & & & & 50.0 & 50.0 & & & & & & & 100.0 \\
\hline 1250 & & & & 12.5 & 75.0 & & 12.5 & & & & & 100.0 & \\
\hline 1300 & & & & & 28.6 & 28.6 & 42.9 & & & & & & \\
\hline 1350 & & & & & & & 100.0 & & & & & & \\
\hline 1400 & & & & & & & 100.0 & & & & & & \\
\hline
\end{tabular}

\begin{tabular}{|c|ccccccc|}
\hline Idade & \multicolumn{2}{|l|}{ Agrupados } & & & & & \\
\hline Classes Lt & 1 & 2 & 3 & 4 & 5 & 6 & 7 \\
\hline 600 & 100.0 & & & & & & \\
650 & 100.0 & & & & & & \\
700 & 33.3 & 66.7 & & & & & \\
750 & & 100.0 & & & & & \\
800 & 33.3 & 66.7 & & & & & \\
850 & & 60.0 & 40.0 & & & & \\
900 & & 36.4 & 45.5 & 18.2 & & & \\
950 & & 10.0 & 50.0 & 30.0 & 10.0 & & \\
1000 & & & 12.5 & 75.0 & 12.5 & & \\
1050 & & & 6.7 & 26.7 & 60.0 & 6.7 & \\
1100 & & & 8.3 & 16.7 & 66.7 & 8.3 & \\
1150 & & & & & 100.0 & & \\
1200 & & & & & 28.6 & 71.4 & \\
1250 & & & & 11.1 & 77.8 & & 11.1 \\
1300 & & & & & 28.6 & 28.6 & 42.9 \\
1350 & & & & & & & 100.0 \\
1400 & & & & & & & 100.0 \\
\hline
\end{tabular}


Tabela 49: Chave idade-comprimento por sexo e agrupados obtida para os exemplares da costa de São Paulo.

\begin{tabular}{|c|c|c|c|c|c|c|c|c|c|c|c|c|c|c|c|c|}
\hline Idade & Fêm & leas & & & & & & & Mac & hos & & & & & & \\
\hline Classes Lt & 0 & 1 & 2 & 3 & 4 & 5 & 6 & 7 & 0 & 1 & 2 & 3 & 4 & 5 & 6 & 7 \\
\hline 300 & & & & & & & & & & & & & & & & \\
\hline 350 & 100 & & & & & & & & 100 & & & & & & & \\
\hline 400 & 100 & & & & & & & & 100 & & & & & & & \\
\hline 450 & 100 & & & & & & & & & & & & & & & \\
\hline 500 & 50 & 50 & & & & & & & 66.7 & 33.3 & & & & & & \\
\hline 550 & & 100 & & & & & & & & & & & & & & \\
\hline 600 & & 100 & & & & & & & & 100 & & & & & & \\
\hline 650 & & 100 & & & & & & & & 50 & 50 & & & & & \\
\hline 700 & & & & & & & & & & & 100 & & & & & \\
\hline 750 & & & 100 & & & & & & & 20 & 60 & 20 & & & & \\
\hline 800 & & 33.36 & 66.7 & & & & & & & & 33.3 & 66.7 & & & & \\
\hline 850 & & & 75 & 25 & & & & & & & 25 & 25 & 25 & 25 & & \\
\hline 900 & & & 50 & 50 & & & & & & & & 33.3 & 66.7 & & & \\
\hline 950 & & & 33.3 & & 66.7 & & & & & & & 33.3 & 66.7 & & & \\
\hline 1000 & & & & 25 & 50 & 25 & & & & & & & 25 & 75 & & \\
\hline 1050 & & & & 16.7 & 83.3 & & & & & & & & & 66.7 & 33.3 & \\
\hline 1100 & & & & 33.3 & 33.3 & 33.3 & & & & & & & 14.3 & 42.9 & 14.3 & 28.6 \\
\hline 1150 & & & & 16.7 & 33.3 & 50 & & & & & & 20 & & 20 & 60 & \\
\hline 1200 & & & & & 42.9 & 14.3 & 42.9 & & & & & & & 50 & & 50 \\
\hline 1250 & & & & & & 50 & 25 & 25 & & & & & & & 100 & \\
\hline 1300 & & & & & & 16.7 & 33.3 & 50 & & & & & & & & 100 \\
\hline 1350 & & & & & & & 100 & & & & & & & & & \\
\hline 1400 & & & & & & & 33.3 & 66.7 & & & & & & & & \\
\hline 1450 & & & & & & & & 100 & & & & & & & & \\
\hline
\end{tabular}

\begin{tabular}{|c|c|c|c|c|c|c|c|c|}
\hline Idade & & rupac & & & & & & \\
\hline Classes Lt & 0 & 1 & 2 & 3 & 4 & 5 & 6 & 7 \\
\hline 300 & 100 & & & & & & & \\
\hline 350 & 100 & & & & & & & \\
\hline 400 & 100 & & & & & & & \\
\hline 450 & 100 & & & & & & & \\
\hline 500 & 60 & 40 & & & & & & \\
\hline 550 & & 100 & & & & & & \\
\hline 600 & & 100 & & & & & & \\
\hline 650 & & 66.7 & 33.3 & & & & & \\
\hline 700 & & & 100 & & & & & \\
\hline 750 & & 14.3 & 71.4 & 14.3 & & & & \\
\hline 800 & & 16.7 & 50 & 33.3 & & & & \\
\hline 850 & & & 50 & 25 & 12.5 & 12.5 & & \\
\hline 900 & & & 20 & 40 & 40 & & & \\
\hline 950 & & & 11.1 & 22.2 & 66.7 & & & \\
\hline 1000 & & & & 8.33 & 33.3 & 58.3 & & \\
\hline 1050 & & & & 11.1 & 55.6 & 22.2 & 11.1 & \\
\hline 1100 & & & & 10 & 20 & 40 & 10 & 20 \\
\hline 1150 & & & & 18.2 & 18.2 & 36.4 & 27.3 & \\
\hline 1200 & & & & & 23.1 & 30.8 & 23.1 & 23.1 \\
\hline 1250 & & & & & & 28.6 & 57.1 & 14.3 \\
\hline 1300 & & & & & & 14.3 & 28.6 & 57.1 \\
\hline 1350 & & & & & & & 100 & \\
\hline 1400 & & & & & & & 33.3 & 66.7 \\
\hline 1450 & & & & & & & & 100 \\
\hline $\mathrm{N}$ & 31 & 12 & 17 & 14 & 25 & 25 & 18 & 14 \\
\hline
\end{tabular}


Tabela 50: Chave idade-comprimento por sexo e agrupados obtida para os exemplares da região de Porto Belo (SC).

\begin{tabular}{|c|c|c|c|c|c|c|c|c|c|c|c|c|c|c|c|c|}
\hline Idade & \multicolumn{9}{|c|}{ Fêmeas } & \multicolumn{7}{|c|}{ Machos } \\
\hline Classes Lt & 0 & 1 & 2 & 3 & 4 & 5 & 6 & 7 & 8 & 0 & 1 & 2 & 3 & 4 & 5 & 6 \\
\hline 300 & 100 & & & & & & & & & 100 & & & & & & \\
\hline 350 & 100 & & & & & & & & & & & & & & & \\
\hline 400 & & & & & & & & & & & & & & & & \\
\hline 450 & & & & & & & & & & 100 & & & & & & \\
\hline 500 & & & & & & & & & & 100 & & & & & & \\
\hline 550 & & & & & & & & & & 100 & & & & & & \\
\hline 600 & & 100 & & & & & & & & & 100 & & & & & \\
\hline 650 & & 100 & & & & & & & & & 100 & & & & & \\
\hline 700 & & 85.7 & 14.3 & & & & & & & & 66.7 & 33.3 & & & & \\
\hline 750 & & 28.6 & 71.4 & & & & & & & & 80 & 20 & & & & \\
\hline 800 & & 33.3 & 66.7 & & & & & & & & 14.3 & 42.9 & 42.9 & & & \\
\hline 850 & & & 75 & 25 & & & & & & & & 50 & 50 & & & \\
\hline 900 & & & 50 & 50 & & & & & & & & & 71.4 & 28.6 & & \\
\hline 950 & & & 25 & 75 & & & & & & & & & 50 & 50 & & \\
\hline 1000 & & & 20 & 10 & 50 & 20 & & & & & & & 85.7 & 14.3 & & \\
\hline 1050 & & & & & 100 & & & & & & & & 40 & 60 & & \\
\hline 1100 & & & & & 37.5 & 62.5 & & & & & & & & 66.7 & 33.3 & \\
\hline 1150 & & & & & 33.3 & 50 & 16.7 & & & & & & & & & \\
\hline 1200 & & & & & 40 & 40 & 20 & & & & & & & 25 & 50 & 25 \\
\hline 1250 & & & & & 20 & 20 & 60 & & & & & & & & & \\
\hline 1300 & & & & & & 16.7 & 66.7 & 16.7 & & & & & & & & \\
\hline 1400 & & & & & & & 50 & 50 & & & & & & & & \\
\hline 1550 & & & & & & & & & 100 & & & & & & & \\
\hline
\end{tabular}

\begin{tabular}{|c|ccccccccc|}
\hline Idade & \multicolumn{2}{|c|}{ Agrupados } & & & & & & \\
\hline Classes Lt & 0 & 1 & 2 & 3 & 4 & 5 & 6 & 7 & 8 \\
\hline 150 & 100 & & & & & & & & \\
200 & 100 & & & & & & & & \\
250 & 100 & & & & & & & & \\
300 & 100 & & & & & & & & \\
350 & 100 & & & & & & & & \\
400 & 100 & & & & & & & & \\
450 & 100 & & & & & & & & \\
500 & 100 & & & & & & & & \\
550 & 100 & & & & & & & & \\
600 & & 100 & & & & & & & \\
650 & & 100 & & & & & & & \\
700 & & 80 & 20 & & & & & & \\
750 & & 50 & 50 & & & & & & \\
800 & & 20 & 50 & 30 & & & & & \\
850 & & & 66.7 & 33.3 & & & & & \\
900 & & & 18.2 & 63.6 & 18.2 & & & & \\
950 & & & 12.5 & 62.5 & 25 & & & & \\
1000 & & & 11.8 & 41.2 & 35.3 & 11.8 & & & \\
1050 & & & & 33.3 & 66.7 & & & & \\
1100 & & & & & 45.5 & 54.5 & & & \\
1150 & & & & & 33.3 & 50 & 16.7 & & \\
1200 & & & & & 33.3 & 44.4 & 22.2 & & \\
1250 & & & & & 20 & 20 & 60 & & \\
1300 & & & & & & 16.7 & 66.7 & 16.7 & \\
1400 & & & & & & & 50 & 50 & 0 \\
1550 & & & & & & & & & 100 \\
\hline
\end{tabular}


Tabela 51: Total capturado no dia de coleta de dados de campo de T. lepturus na Prainha (Arraial do Cabo, RJ), no período de janeiro de 2002 a julho de 2003.

\begin{tabular}{c|c}
\hline Mês & Captura (kg) \\
\hline jan/02 & 480 \\
fev/02 & 431 \\
mar/02 & 662 \\
abr/02 & 188 \\
mai/02 & 614 \\
jun/02 & 580 \\
jul/02 & 532 \\
ago/02 & 298 \\
set/02 & 550 \\
set/02 & 30 \\
out/02 & 578 \\
nov/02 & 804 \\
dez/02 & 474 \\
jan/03 & 144 \\
fev/03 & 400 \\
mar/03 & 2188 \\
abr/03 & 242 \\
mai/03 & 250 \\
jun/03 & 120 \\
jul/03 & 400 \\
\hline Total & 9965 \\
\hline
\end{tabular}

Tabela 52: Produção mensal de T. lepturus na costa de São Paulo capturada com arrasto de fundo com parelhas (fonte Instituto de Pesca/ APTA/SAA/SP). Em negrito o período de amostragem deste trabalho.

\begin{tabular}{|c|c|c|c|c|c|c|c|c|c|}
\hline Aparelho & Mês & 1998 & 1999 & 2000 & 2001 & 2002 & 2003 & 2004 & Total \\
\hline \multirow[t]{12}{*}{ parelha } & 1 & 3050 & 1440 & 10647 & 8714 & 35209 & 25670 & 14730 & 99460 \\
\hline & 2 & 500 & 6959 & 12880 & 17490 & 10366 & 15530 & 29750 & 93475 \\
\hline & 3 & 700 & 4792 & 12110 & 13036 & 12030 & 25970 & 33000 & 101638 \\
\hline & 4 & 5700 & 2457 & 23476 & 24494 & 2350 & 22040 & 23120 & 103637 \\
\hline & 5 & 2817 & 6798 & 31402 & 11880 & 3918 & 25830 & 17000 & 99645 \\
\hline & 6 & 2650 & 2150 & 12619 & 20228 & 3111 & 20646 & 14400 & 75804 \\
\hline & 7 & 1026 & 3060 & 10856 & 5122 & 15693 & 18950 & 18490 & 73197 \\
\hline & 8 & 5100 & 2942 & 8968 & 11241 & 1644 & 5120 & 3800 & 38815 \\
\hline & 9 & 5750 & 3715 & 9334 & 2656 & 7717 & 10650 & 6530 & 46352 \\
\hline & 10 & 6300 & 9433 & 12507 & 11992 & 3200 & 9314 & 2150 & 54896 \\
\hline & 11 & 15260 & 10258 & 7068 & 10210 & 7750 & 3650 & 8300 & 62496 \\
\hline & 12 & 11210 & 14788 & 18954 & 21680 & 13110 & 7358 & 10750 & 97850 \\
\hline \multicolumn{2}{|c|}{ Total } & 60063 & 68792 & 170821 & 158743 & 116098 & 190728 & 182020 & 947265 \\
\hline
\end{tabular}


Tabela 53: Taxas de mortalidade total (Z) obtidas para T. lepturus pelos métodos de Curva de Captura e de Ssentongo \& Larkin, e respectivas taxas de sobrevivência (S).

\begin{tabular}{|c|c|c|c|c|c|c|c|}
\cline { 2 - 8 } \multicolumn{1}{c|}{} & $\begin{array}{c}\mathbf{Z} \\
\text { Curva de } \\
\text { Captura }\end{array}$ & $\begin{array}{c}\text { No. de } \\
\text { pontos }\end{array}$ & IC & $\begin{array}{c}\mathbf{S ~ ( \% )} \\
\text { Curva de } \\
\text { Captura }\end{array}$ & $\begin{array}{c}\mathbf{Z} \\
\text { Ssen \& Lark }\end{array}$ & $\begin{array}{c}\text { Var (Z/k) } \\
\text { Ssen \& Lark }\end{array}$ & $\begin{array}{c}\mathbf{S}(\%) \\
\text { Ssen \& Lark }\end{array}$ \\
\hline RJ & 1,288 & 9 & $1,160-1,413$ & 27,58 & 0,366 & 0,02 & 69,32 \\
\hline SP & 0,857 & 9 & $0,786-0,927$ & 42,45 & 0,414 & 0,004 & 66,11 \\
\hline SC & 0,971 & 13 & $0,879-1,061$ & 37,87 & 0,438 & 0,006 & 64,53 \\
\hline
\end{tabular}

Tabela 54: A: Estimadores de parâmetros utilizados para o cálculo de mortalidade natural dos diversos modelos propostos. $\mathrm{L}_{\mathrm{oo}}=$ comprimento máximo assintótico $(\mathrm{em} \mathrm{cm}) ; \mathrm{k}=$ taxa de crescimento $\left(\mathrm{ano}^{-1}\right) ; \mathrm{t}_{0}=$ idade teórica no comprimento zero (anos); $\mathrm{T}\left({ }^{\circ} \mathrm{C}\right)=$ temperatura média anual da água; Tmáx $=$ longevidade (anos); $\mathrm{T}_{50}=$ idade de primeira maturação sexual.

B: Taxas de mortalidade natural (M) obtidas por diversos métodos para T. lepturus de cada Estado analisado.

\begin{tabular}{|c|c|c|c|}
\cline { 2 - 4 } \multicolumn{1}{c|}{$\mathbf{A}$} & $\mathbf{R J}$ & $\mathbf{S P}$ & $\mathbf{S C}$ \\
\hline $\mathrm{L}_{\mathrm{oo}}$ & 1888,81 & 1628,87 & 1616,97 \\
\hline $\mathrm{k}$ & 0,125 & 0,186 & 0,202 \\
\hline $\mathrm{t}_{0}$ & $-2,603$ & $-1,654$ & $-1,599$ \\
\hline $\mathrm{T}^{\mathrm{o}} \mathrm{C}$ & 24 & 24 & 24 \\
\hline $\mathrm{Tm}_{\mathrm{max}}$ & 21,36 & 14,45 & 13,23 \\
\hline $\mathrm{T}_{50}$ & 0,91 & 0,83 & 0,70 \\
\hline
\end{tabular}

\begin{tabular}{|c|c|c|c|c|}
\cline { 2 - 5 } \multicolumn{1}{c|}{ B } & M Pauly & M Alagaraja & M Hoenig & $\begin{array}{c}\text { M Rikhter \& } \\
\text { Efanov }\end{array}$ \\
\hline RJ & 0,204 & 0,215 & 0,193 & 0,471 \\
\hline SP & 0,276 & 0,319 & 0,287 & 0,585 \\
\hline SC & 0,292 & 0,348 & 0,314 & 0,348 \\
\hline
\end{tabular}


Tabela 55: Taxas de mortalidade por pesca (F - /ano) e taxas de explotação obtidas para T. lepturus em cada Estado, para as diferentes estimativas de taxa de mortalidade.

\begin{tabular}{|c|c|c|c|c|}
\cline { 2 - 5 } \multicolumn{1}{c|}{} & \multicolumn{2}{c|}{ Z Curva de Captura } & \multicolumn{2}{c|}{ Z Ssentongo \& Larkin } \\
\cline { 2 - 5 } \multicolumn{1}{c|}{} & $\mathbf{F}$ & $\mathbf{E}$ & $\mathbf{F}$ & $\mathbf{E}$ \\
\hline RJ & 1,084 & 0,842 & 0,162 & 0,443 \\
\hline SP & 0,581 & 0,678 & 0,138 & 0,334 \\
\hline SC & 0,679 & 0,700 & 0,146 & 0,334 \\
\hline
\end{tabular}

Tabela 56: Taxas de explotação $\mathrm{E}_{\max }$ e $\mathrm{E}_{0.1}$ e taxas de mortalidade por pesca $\mathrm{F}_{\max }$ e $\mathrm{F}_{0.1}$ obtidas para $T$. lepturus em cada Estado, utilizando-se a taxa de mortalidade natural do modelo empírico de Pauly.

\begin{tabular}{|c|c|c|c|c|}
\cline { 2 - 5 } \multicolumn{1}{c|}{} & $\mathbf{E}_{\mathbf{m a x}}$ & $\mathbf{E}_{\mathbf{0 . 1}}$ & $\mathbf{F}_{\mathbf{m a x}}$ & $\mathbf{F}_{\mathbf{0 . 1}}$ \\
\hline $\mathbf{R J}$ & 0,67 & 0,57 & 0,41 & 0,18 \\
\hline $\mathbf{S P}$ & 0,73 & 0,61 & 0,61 & 0,27 \\
\hline SC & 0,56 & 0,46 & 0,34 & 0,22 \\
\hline
\end{tabular}




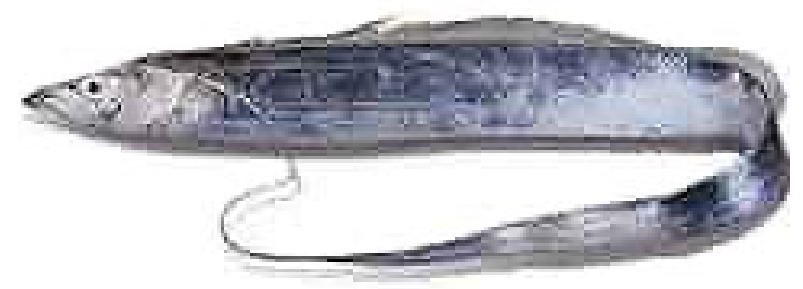

Figura 01: Espada Trichiurus lepturus (Linnaeus, 1758) (Trichiuridae, Teleostei)

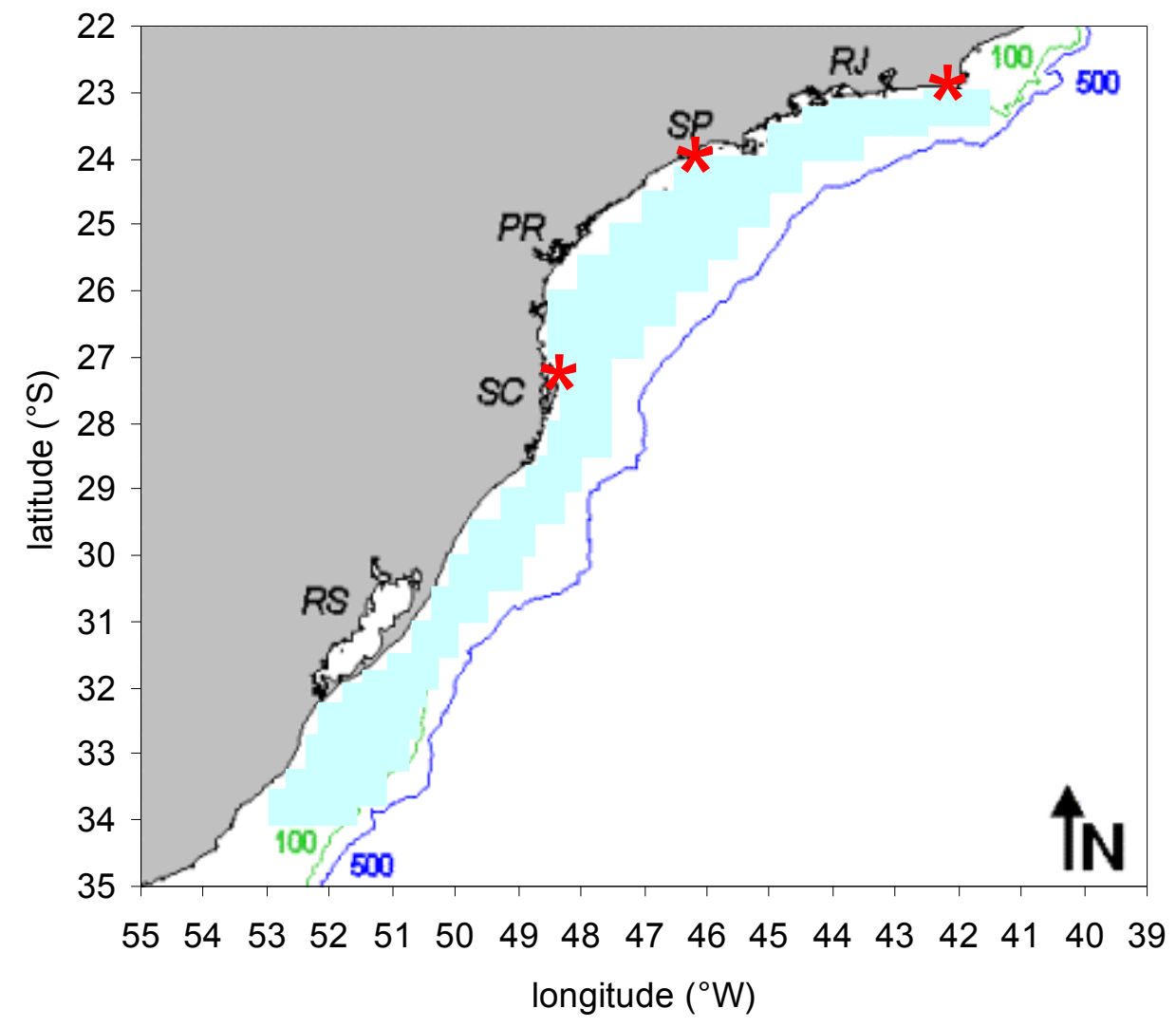

Figura 02: Área de distribuição da espécie Trichiurus lepturus na região sudeste-sul do Brasil ( em azul) e pontos de coleta de amostras $(*)$ 


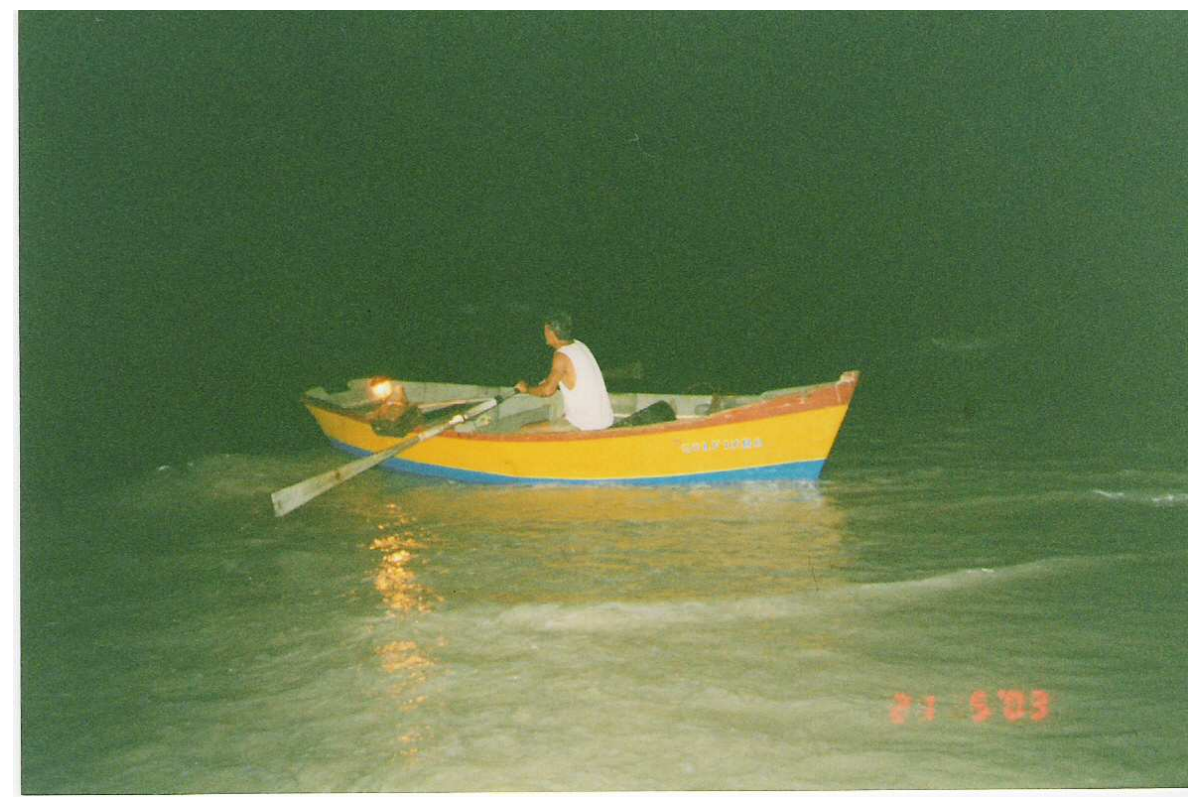

Figura 03: Pesca artesanal de linha de mão - Arraial do Cabo (RJ)

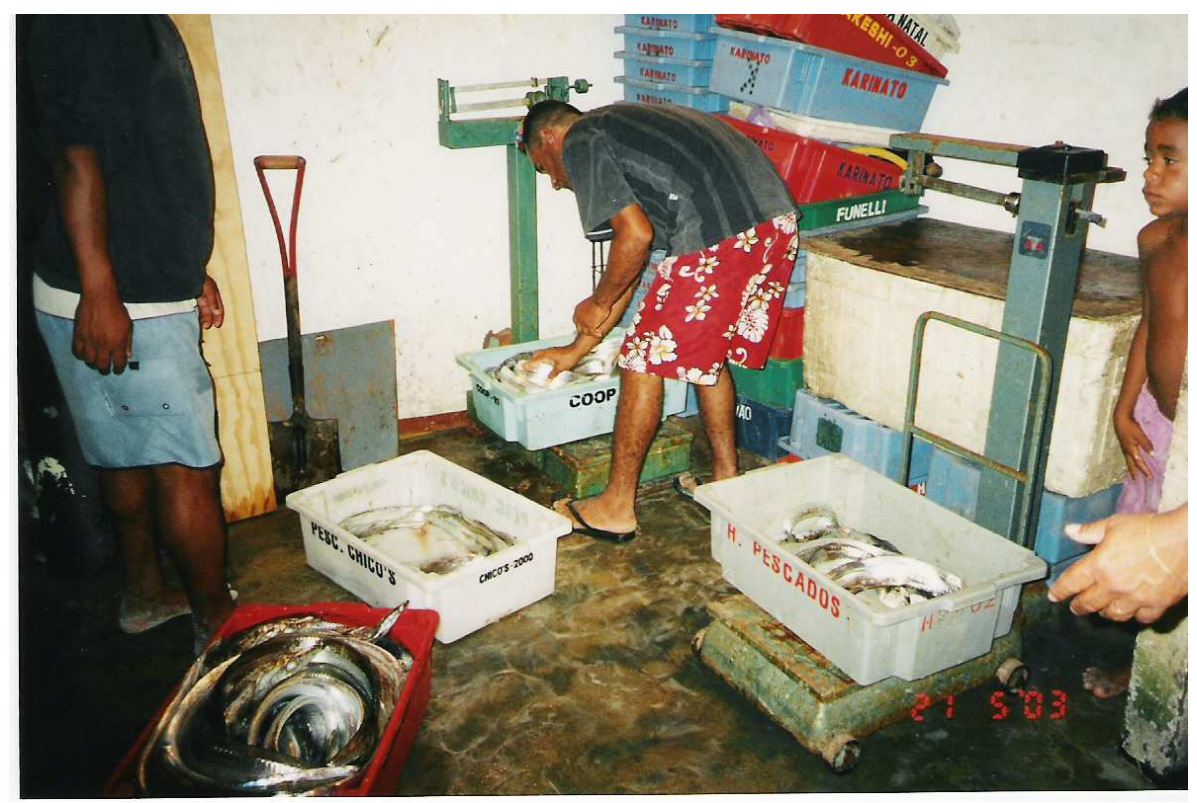

Figura 04: Pescadores pesando a produção de pescado em caixas de até $20 \mathrm{~kg}$. 


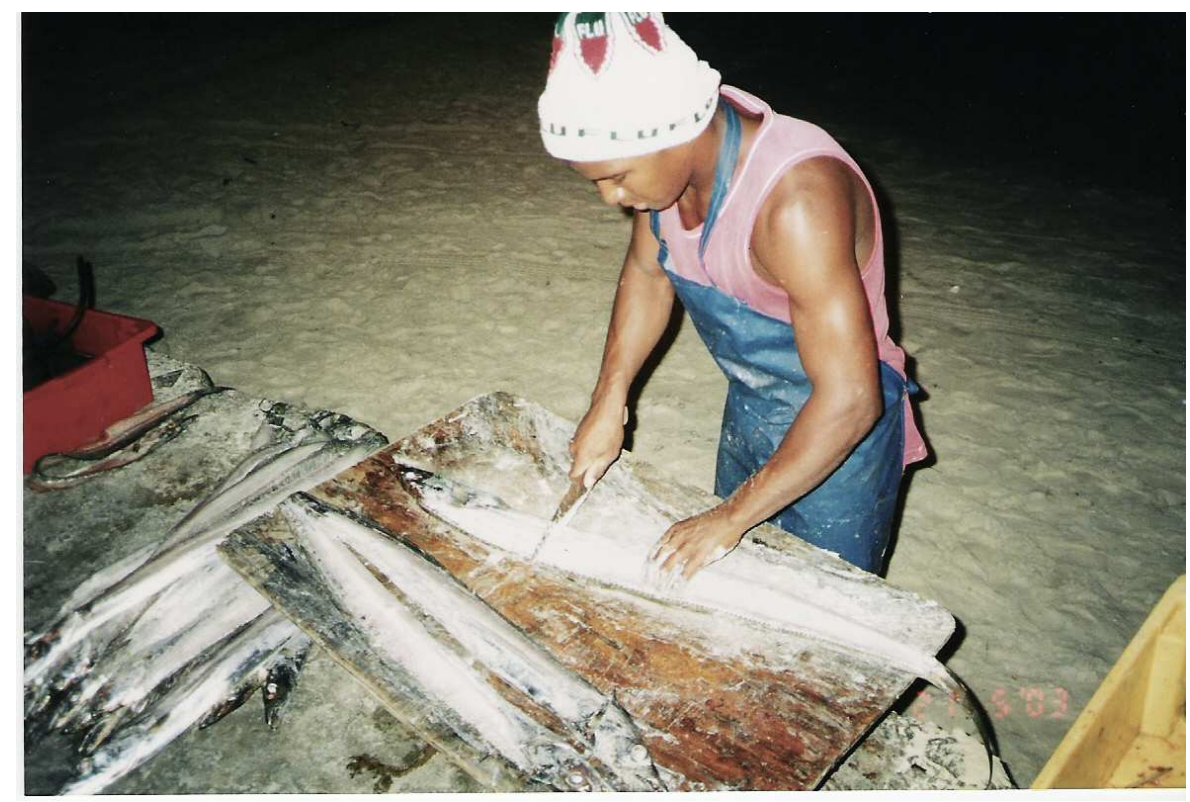

Figura 05: Pescador limpando os peixes a céu aberto para retirada dos filés.

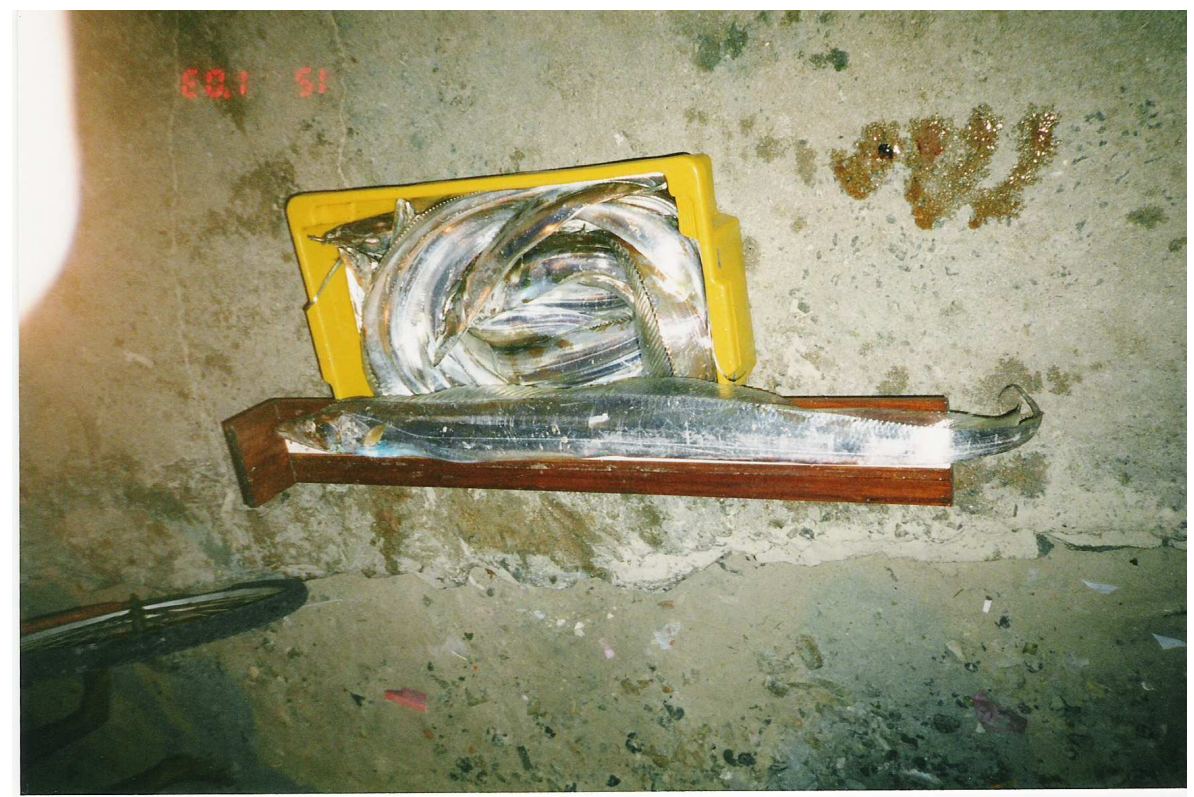

Figura 06: Obtenção dos dados biométricos em campo - Arraial do Cabo (RJ) 


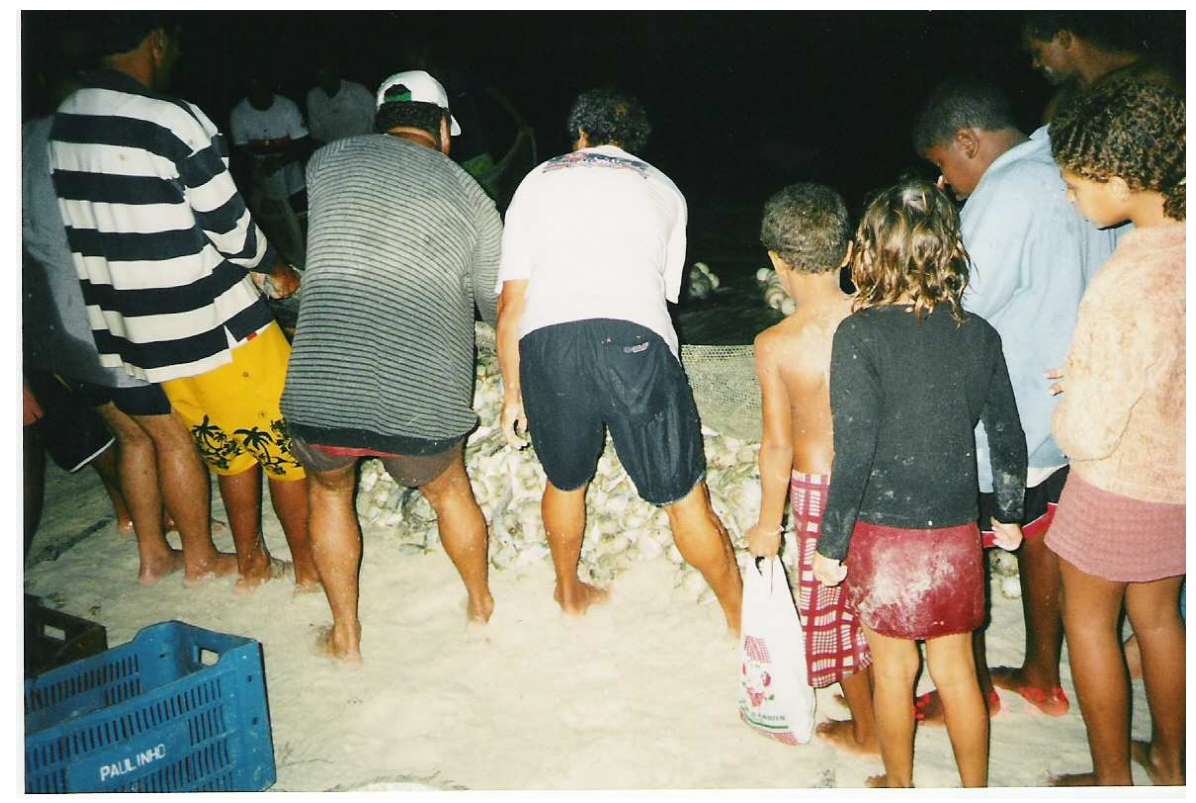

Figura 07: Arrasto de praia noturno - Prainha - Arraial do Cabo (RJ)

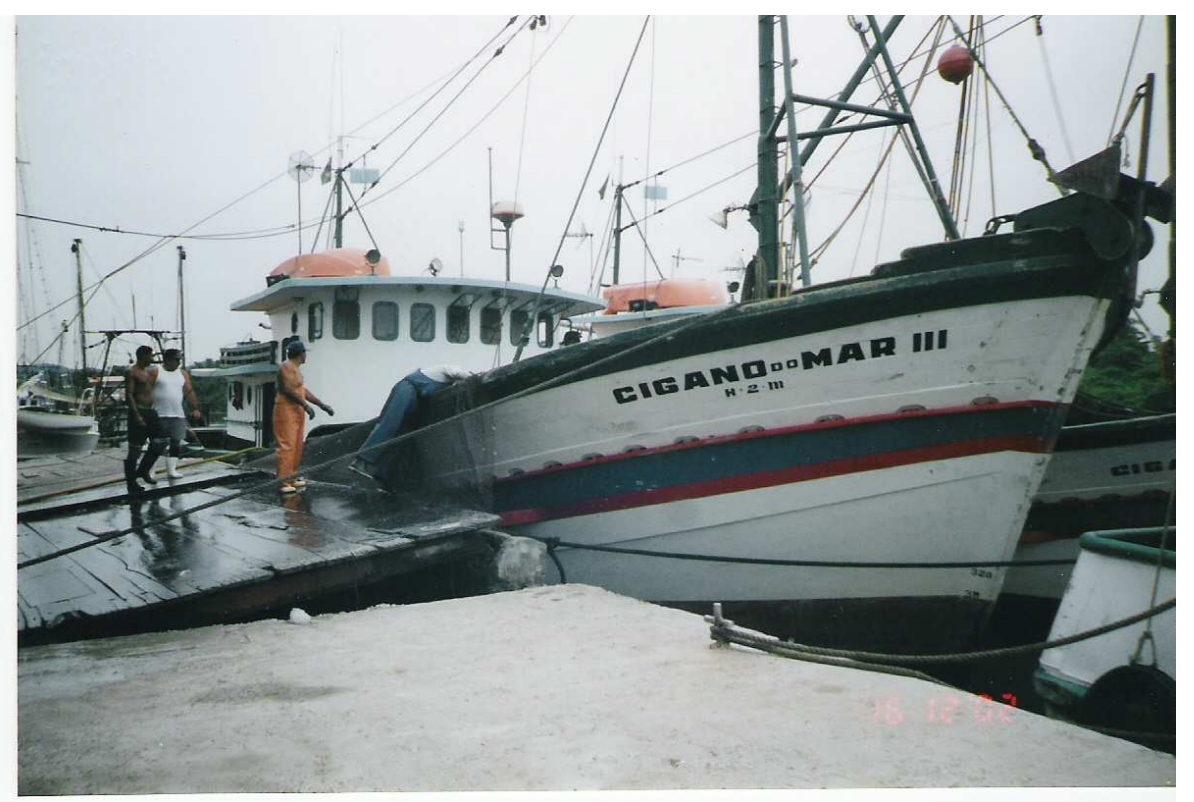

Figura 08: Barco da parelha Cigano do Mar III e Cigano do Mar IV - Guarujá (SP) 


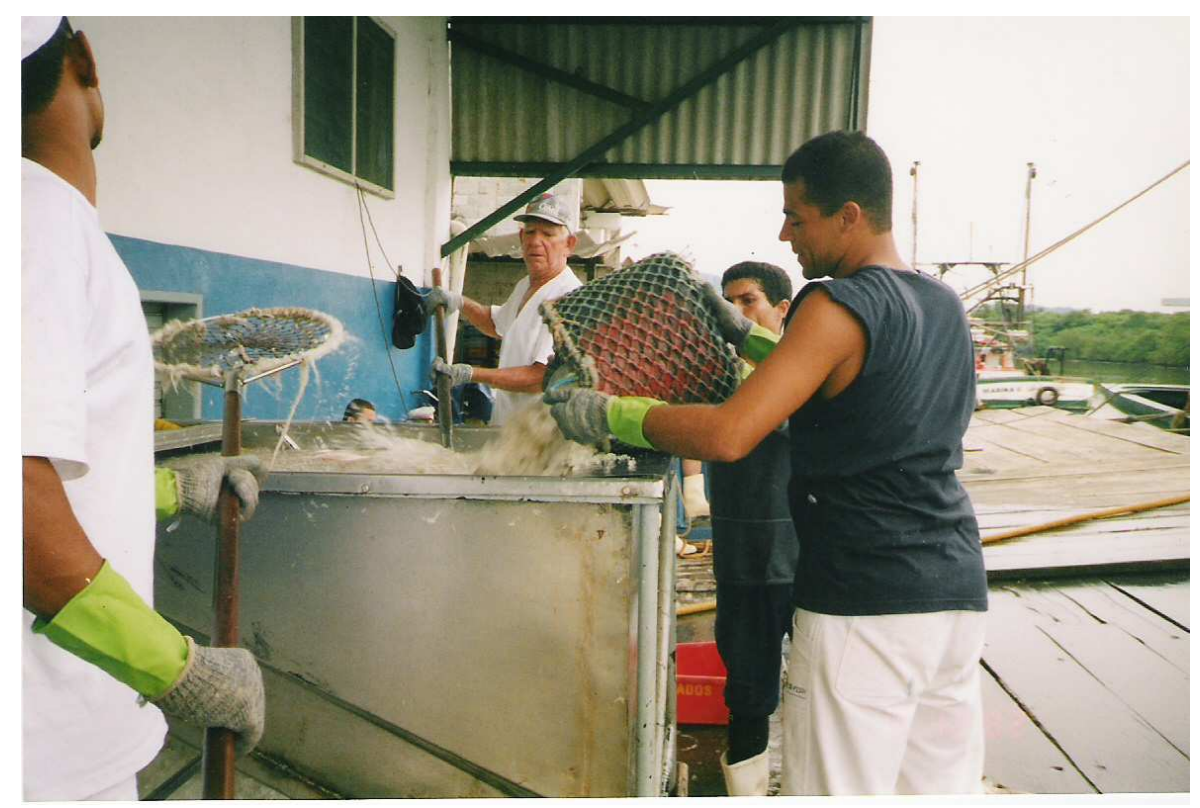

Figura 09: Pescado passando pela pré-lavagem no momento da descarga - Itafish - Guarujá (SP)

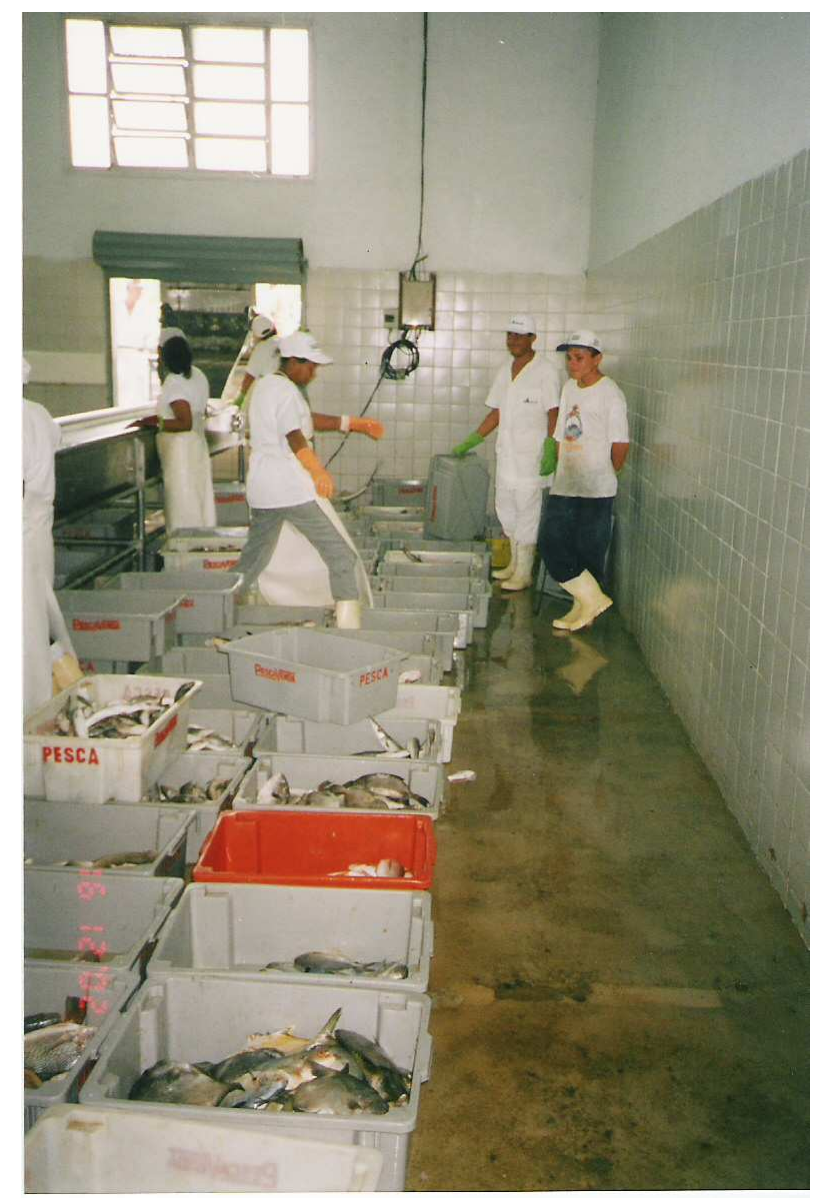

Figura 10: Triagem das espécies para comercialização - Itafish - Guarujá (SP) 


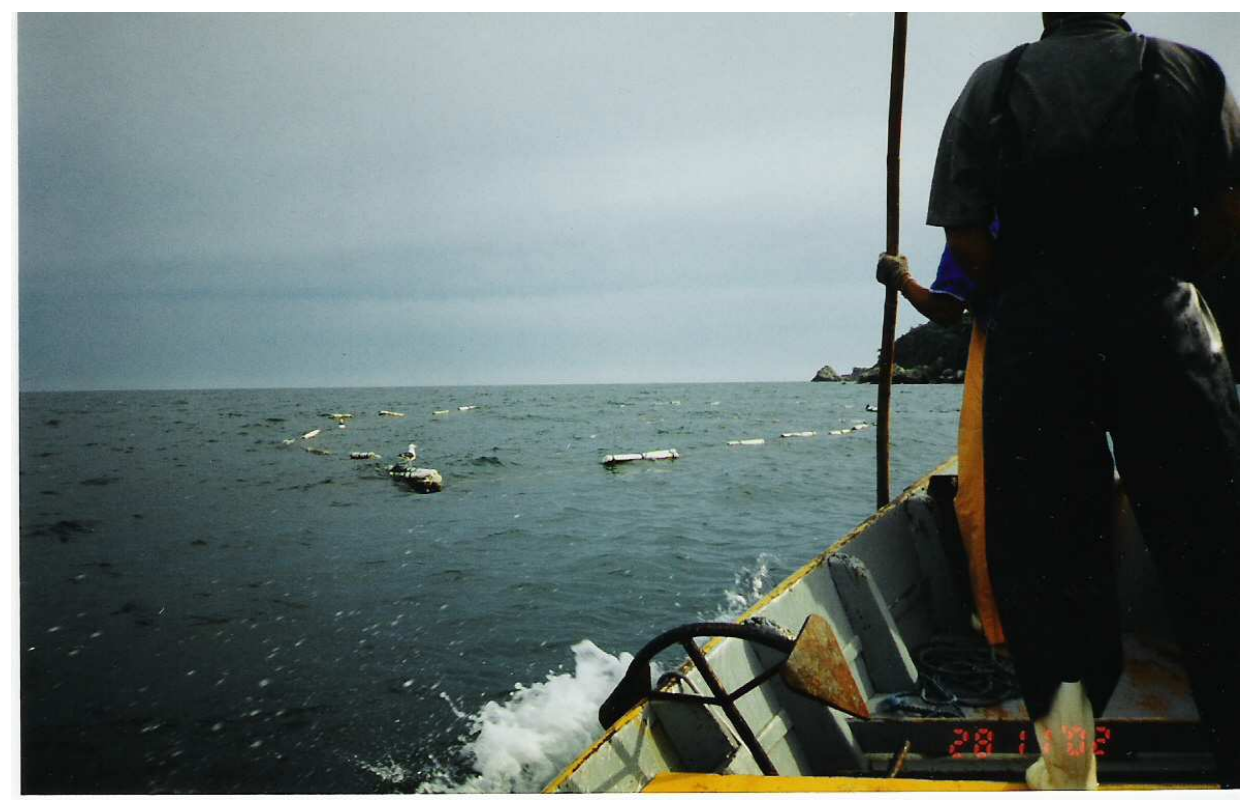

Figura 11: Cerco flutuante da Praia do Estaleiro - Porto Belo (SC)

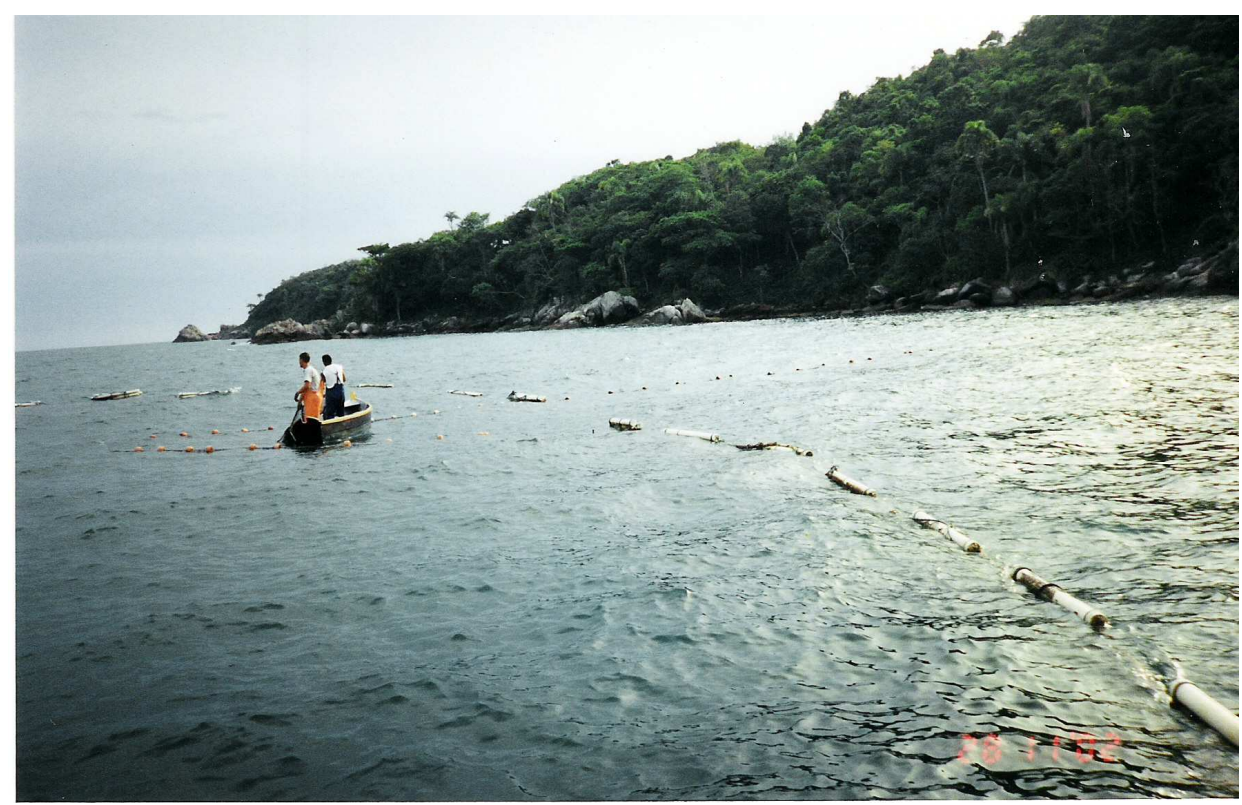

Figura 12: Canoa fechando a boca da rede de cerco (círculo menor - bóias vermelhas) - Porto belo (SC) 


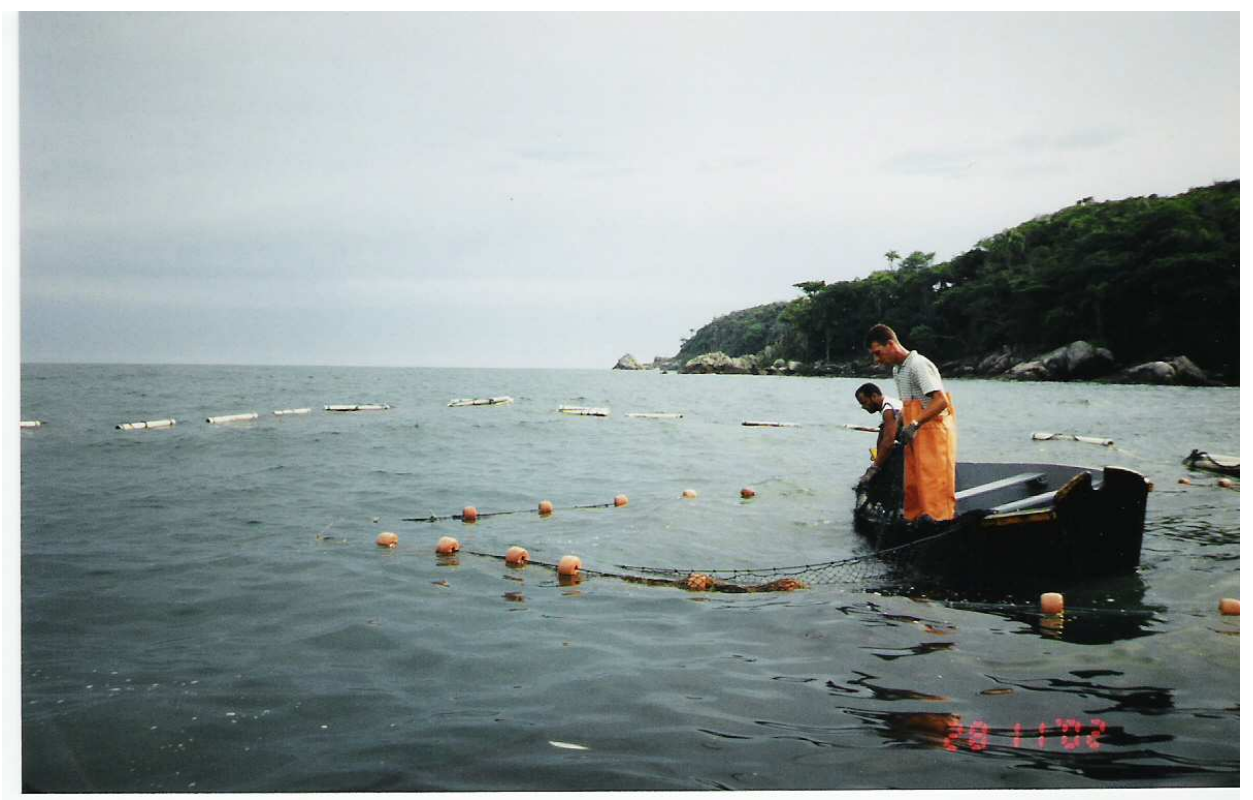

Figura 13: Detalhe da boca da rede de cerco flutuante

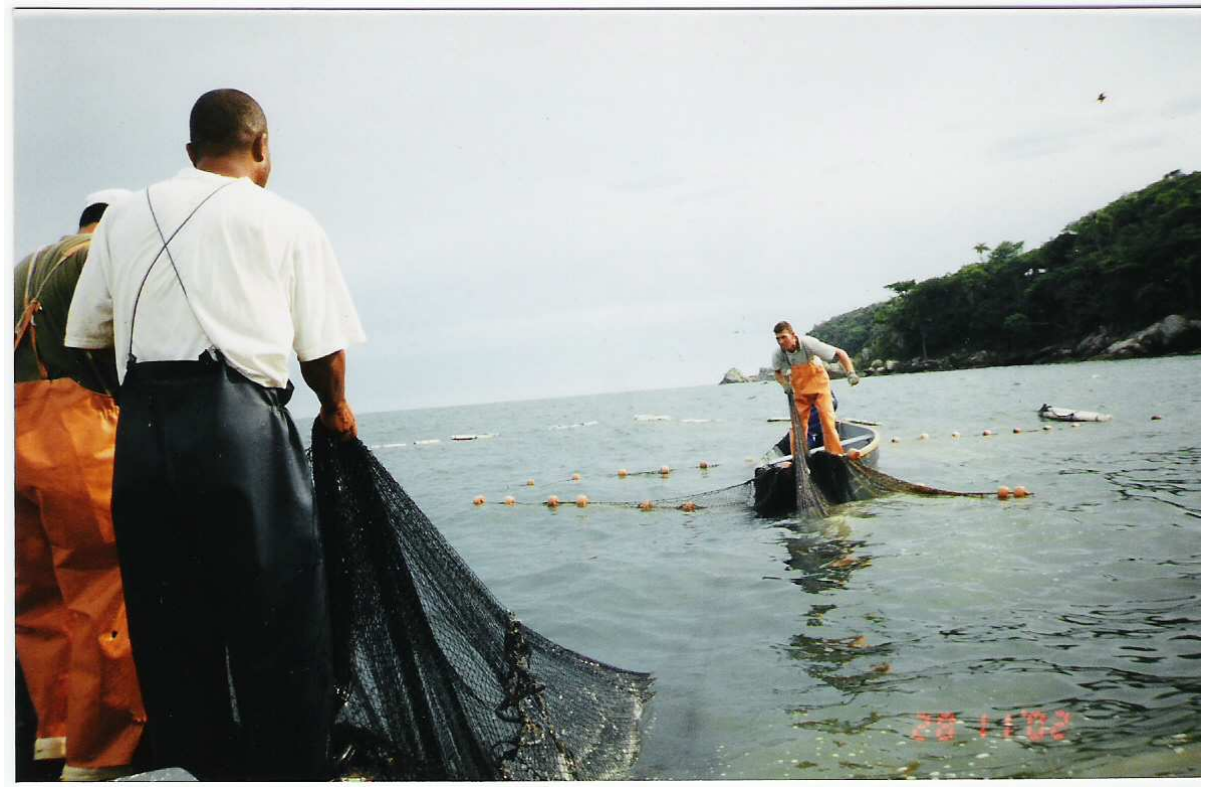

Figura 14: Procedimento de despesca da rede de cerco flutuante - Porto Belo (SC) 

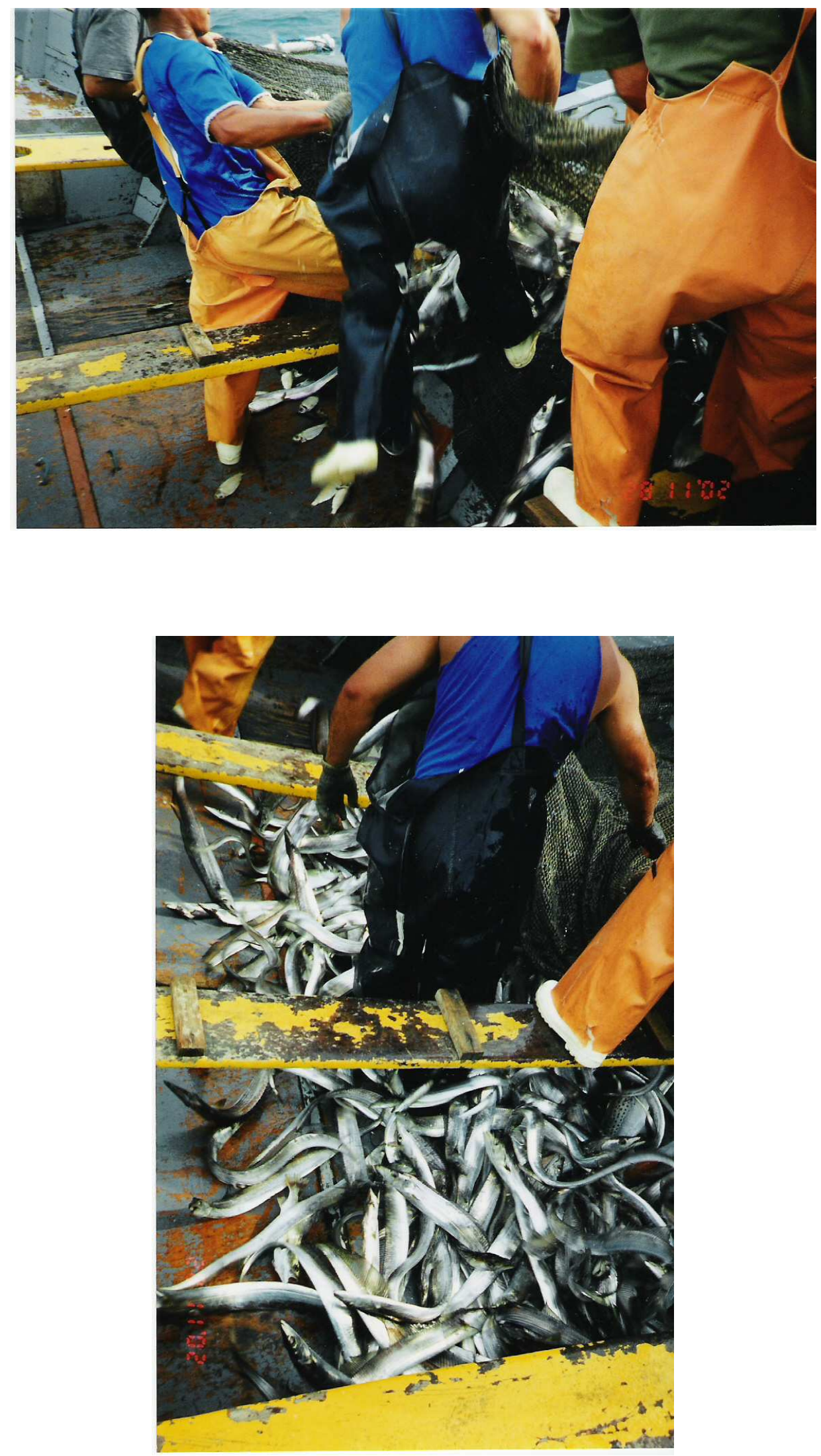

Figura 15: Pescadores trazendo o capturado para o interior da chata "Katu" - Porto Belo (SC) 


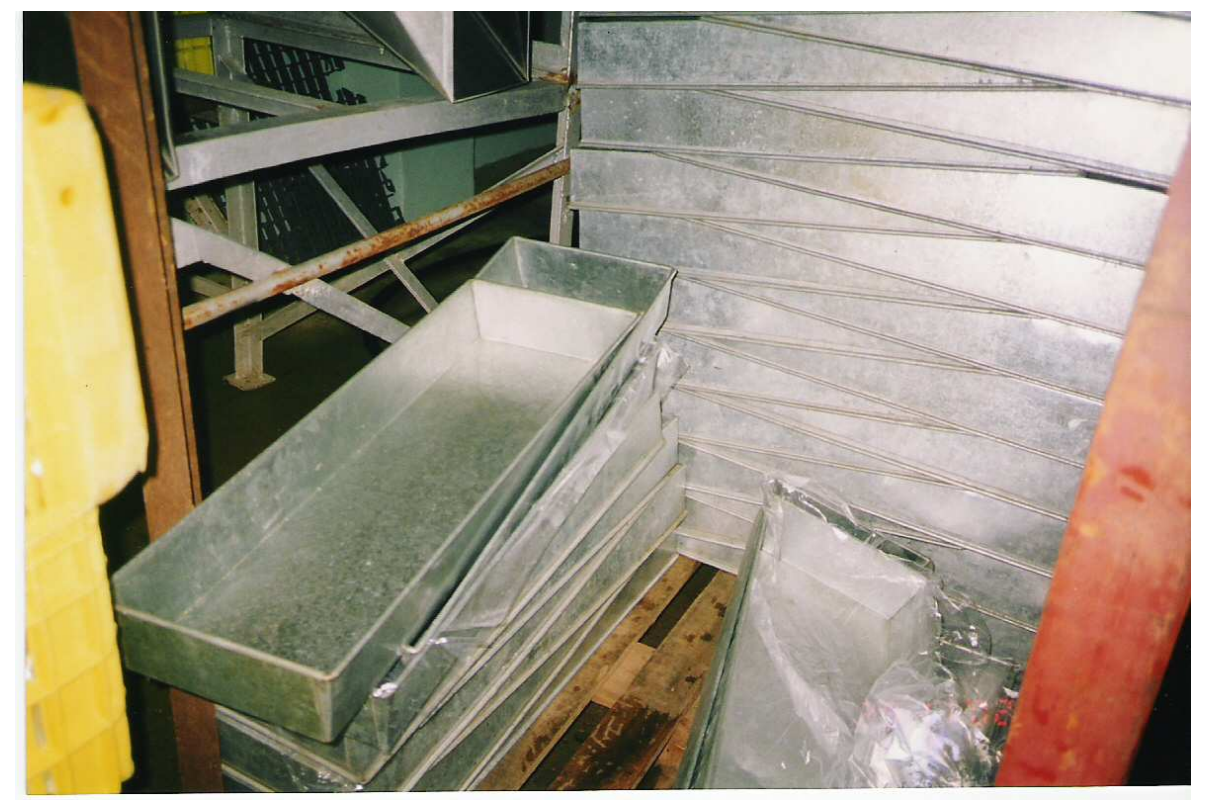

Figura 16: Formas para acondicionamento do espada em freezer - Pioneira da Costa S.A.

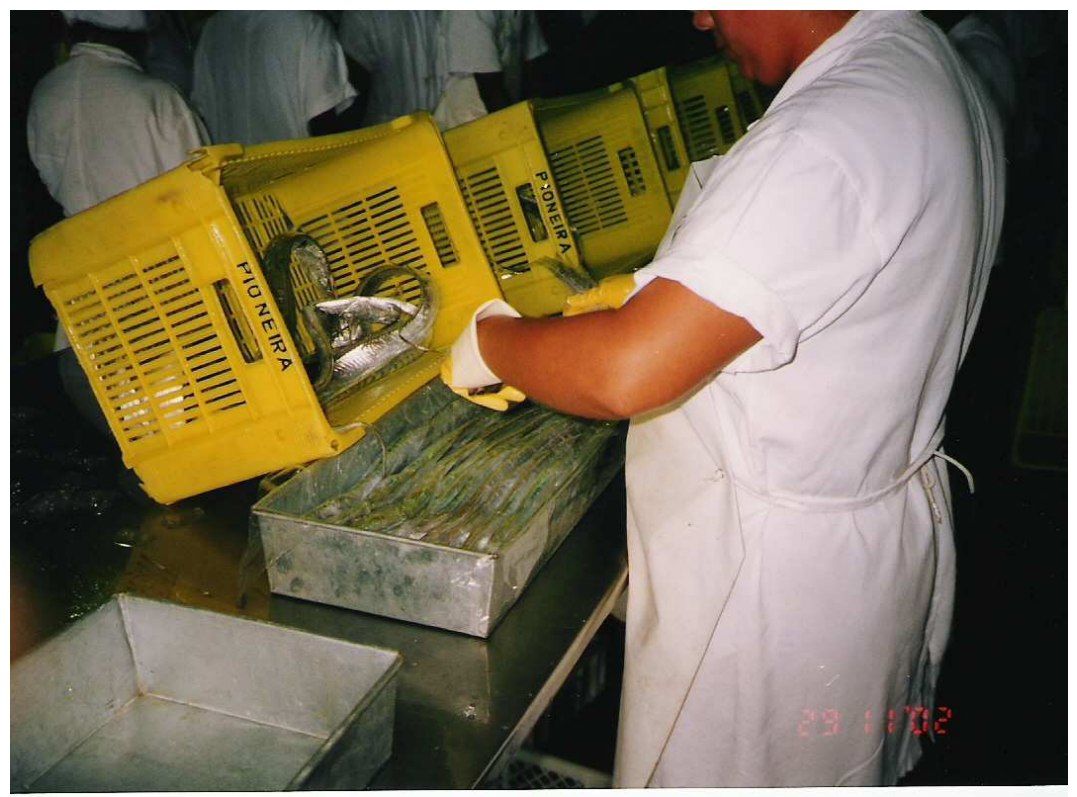

Figura 17: Acondicionamento dos espadas nas formas metálicas para congelamento - Pioneira da Costa S.A. 


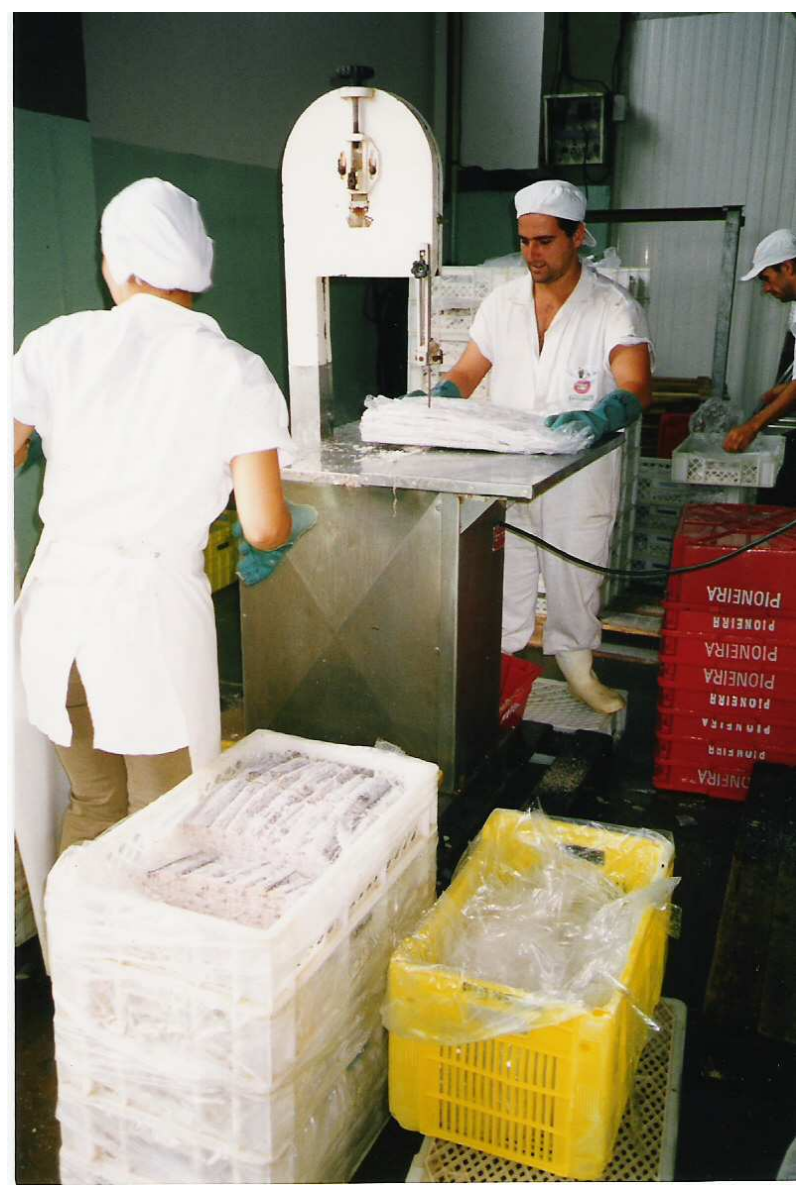

Figura 18: Corte dos blocos de espada congelados para transporte e comercialização

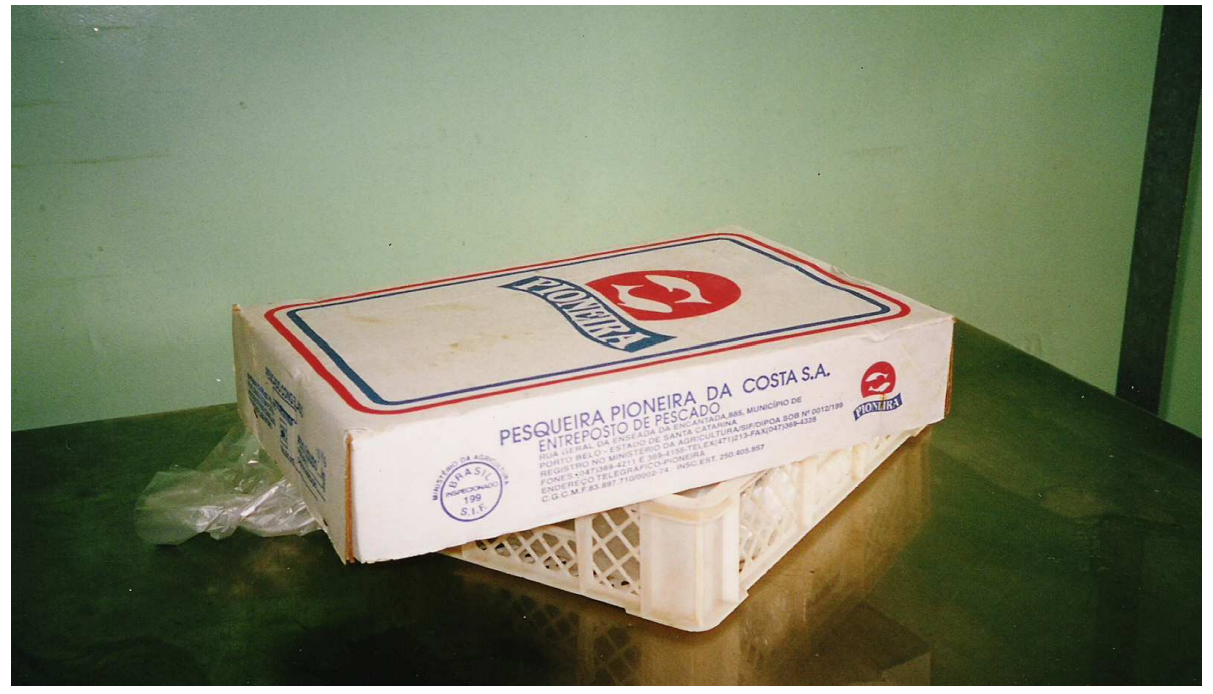

Figura 19: Caixa para acondicionamento e transporte do produto 


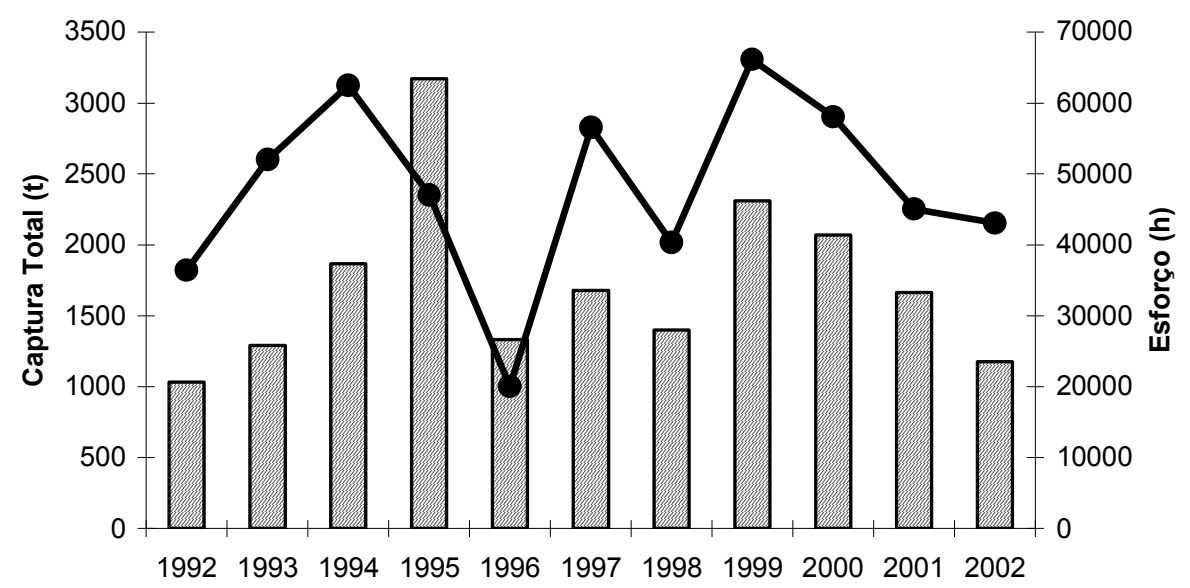

Ano

Figura 20: Captura e esforço de pesca anuais, verificados no período de 1992 a 2002 na região de Arraial do Cabo (RJ),

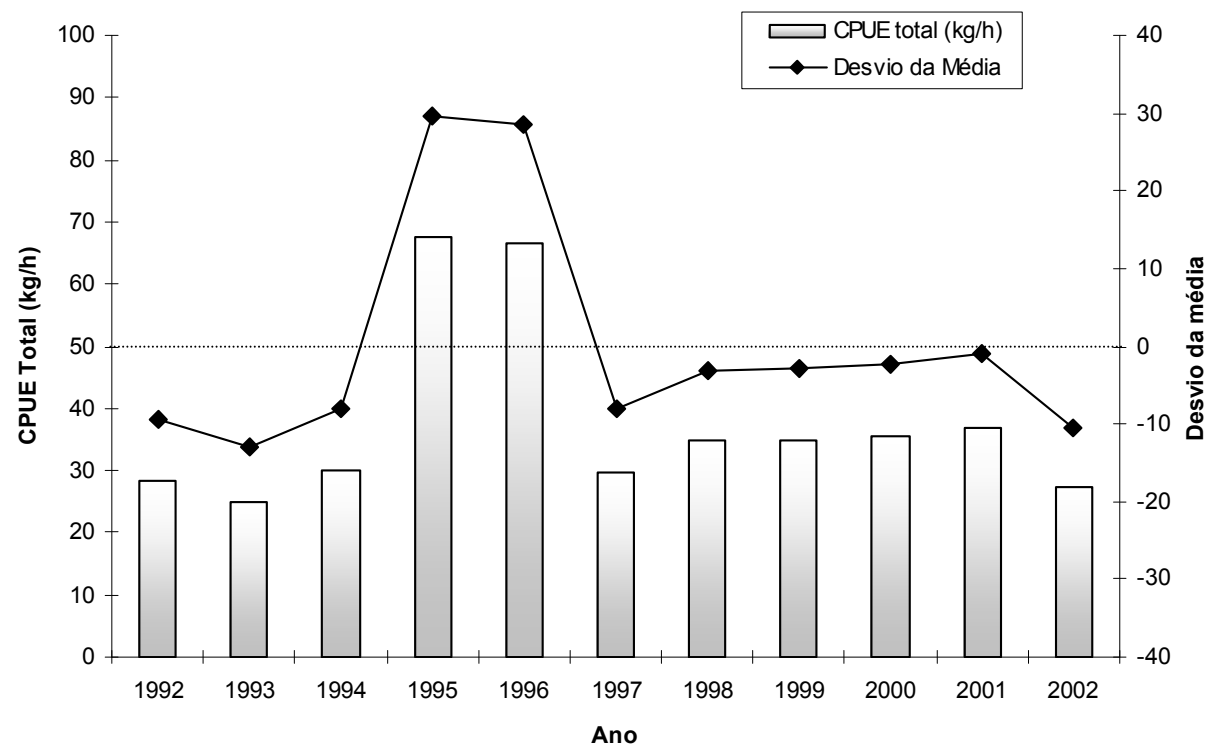

Figura 21: Captura por unidade de esforço (CPUE) anual da pesca em Arraial do Cabo (RJ) e respectivos desvios da média, no período de 1992 a 2002, 


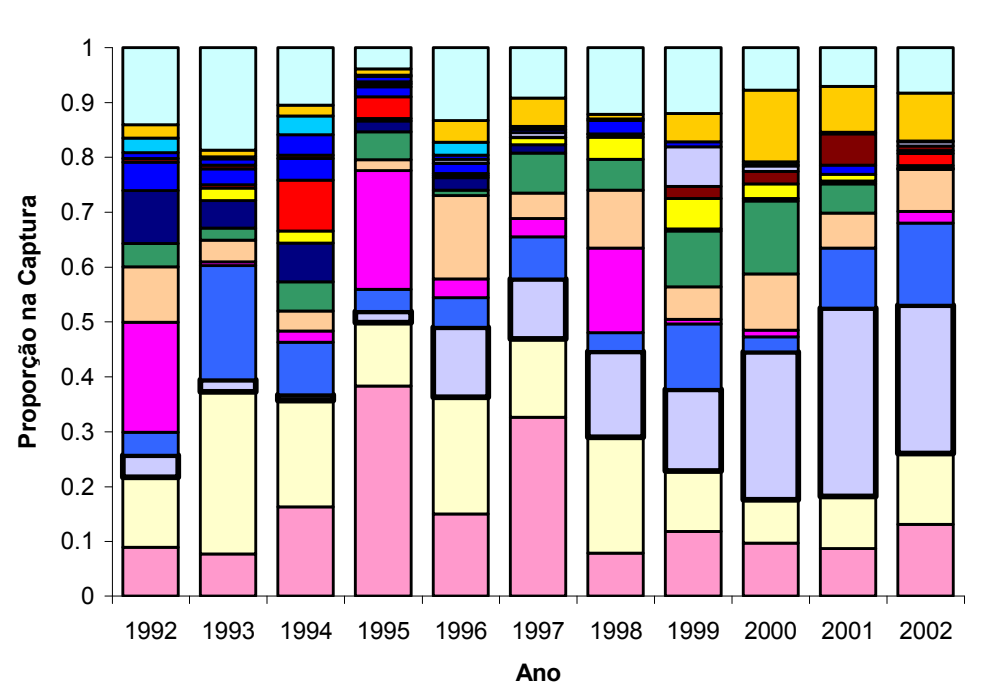

$\square$ Outros

$\square$ Lula

$\square$ Xaréu

$\square$ Tainha

$\square$ Parati

$\square$ Palombeta

$\square$ Serra

$\square$ Sardinha lage

$\square$ Namorado

Galo

$\square$ Dourado

$\square$ Xerelete

$\square$ Cavalinha

$\square$ Bonito-Pintado

口Espada

$\square$ Enchova

$\square$ Sardinha Verdadeira

Figura 22: Proporção das principais espécies na captura anual de Arraial do Cabo (RJ), no período de 1992 a 2002,

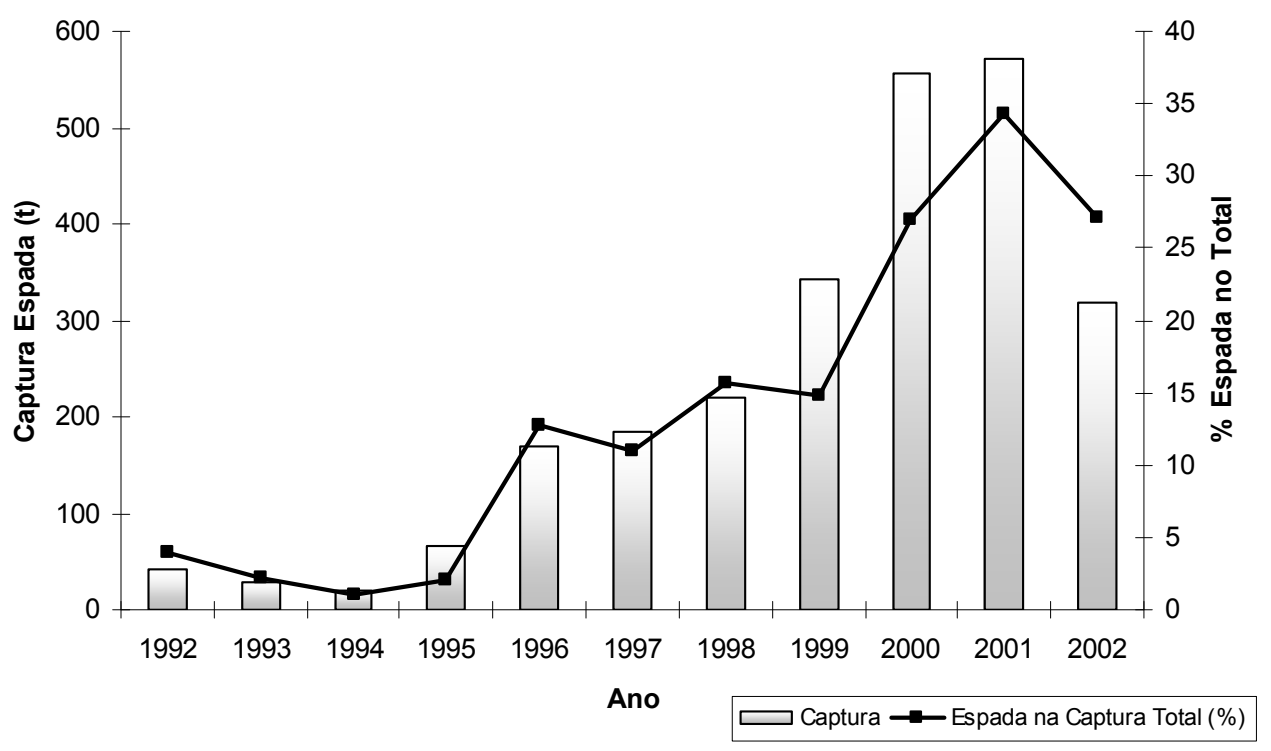

Figura 23: Produção anual de Trichiurus lepturus e respectivas proporções do total capturado no período de 1992 a 2002, na região de Arraial do Cabo (RJ). 


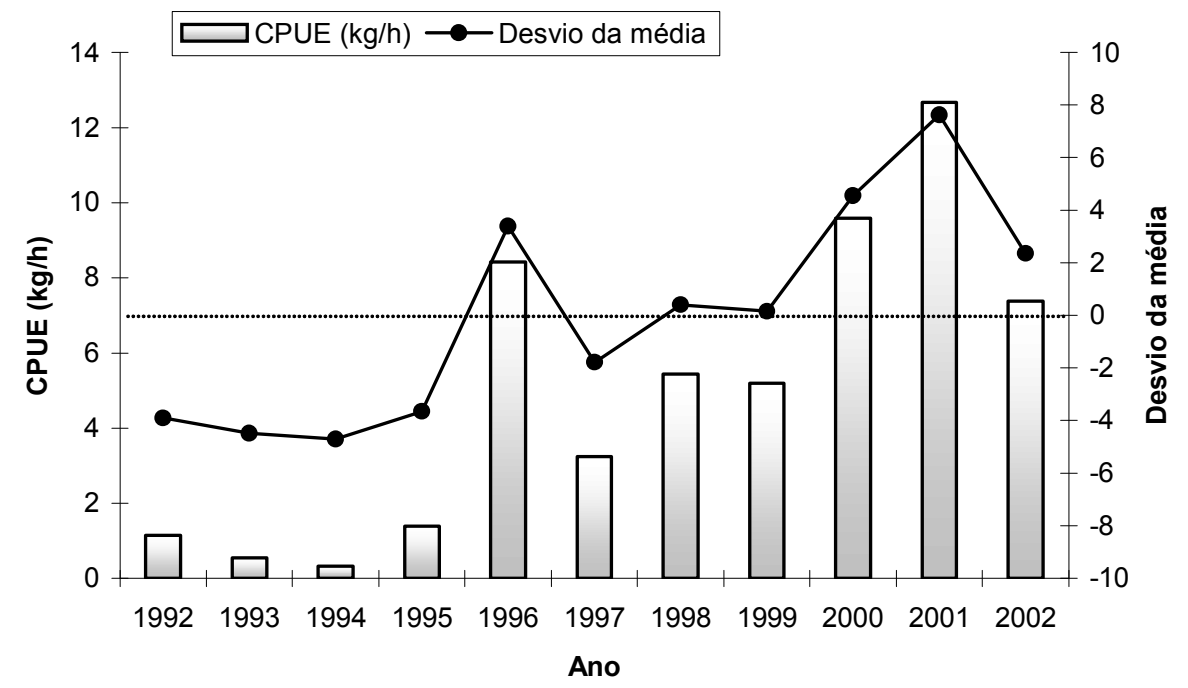

Figura 24: Captura por unidade de esforço (CPUE) anual de Trichiurus lepturus da região de Arraial do Cabo (RJ) e respectivos desvios da média, no período de 1992 a 2002,

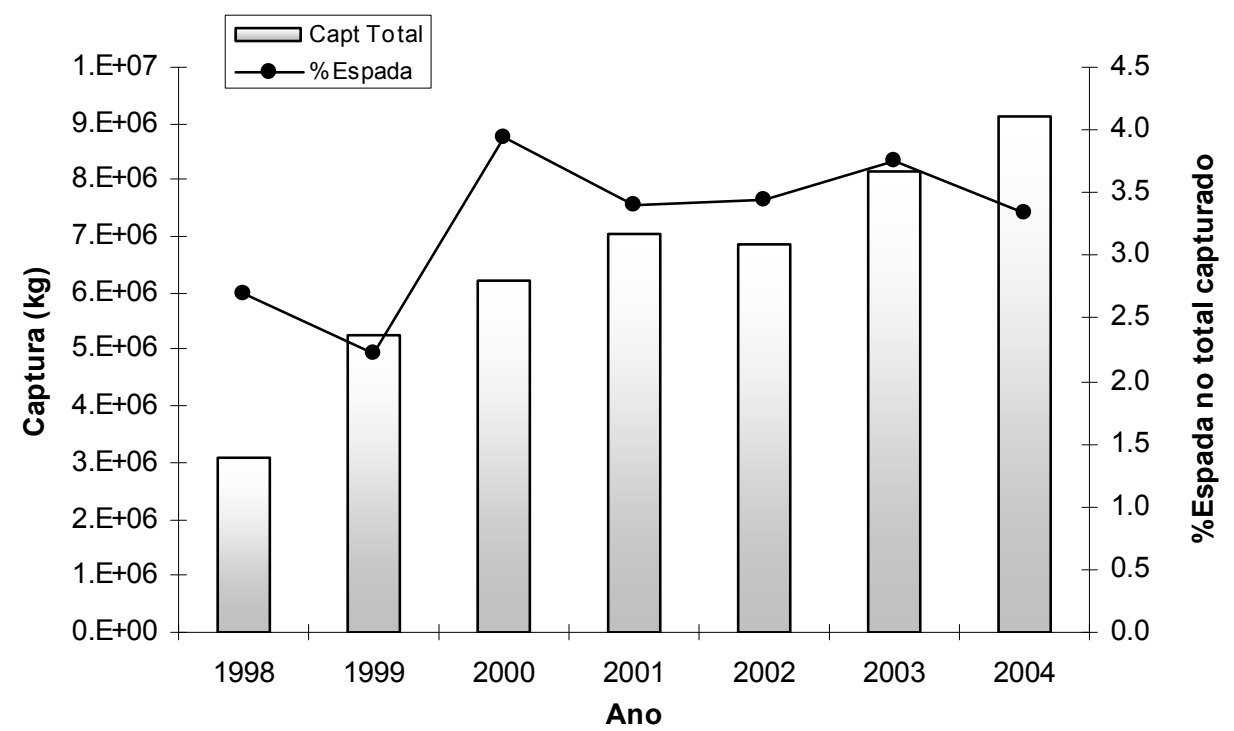

Figura 25: Produção total anual desembarcada em São Paulo (em $\mathrm{kg}$ ) e respectivas proporções de $T$. lepturus no período 1998-2004. 


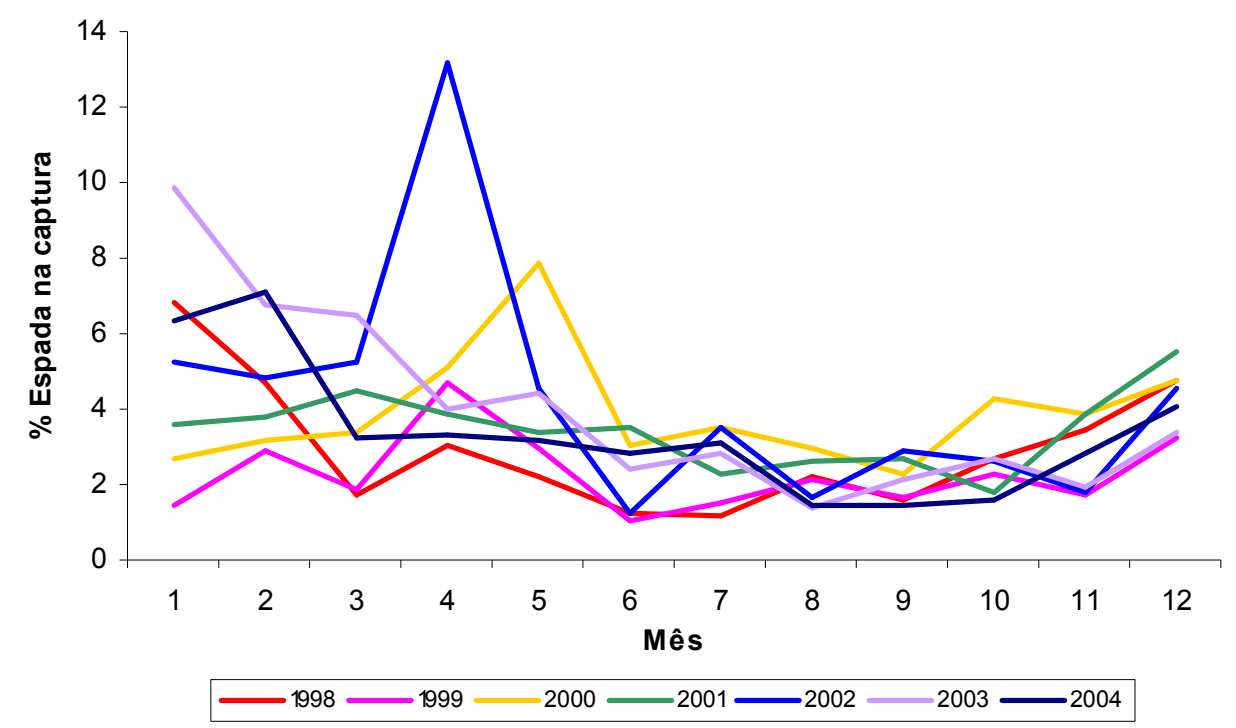

Figura 26: Proporções mensais de T. lepturus na captura total desembarcada em São Paulo no período 1998-2004.

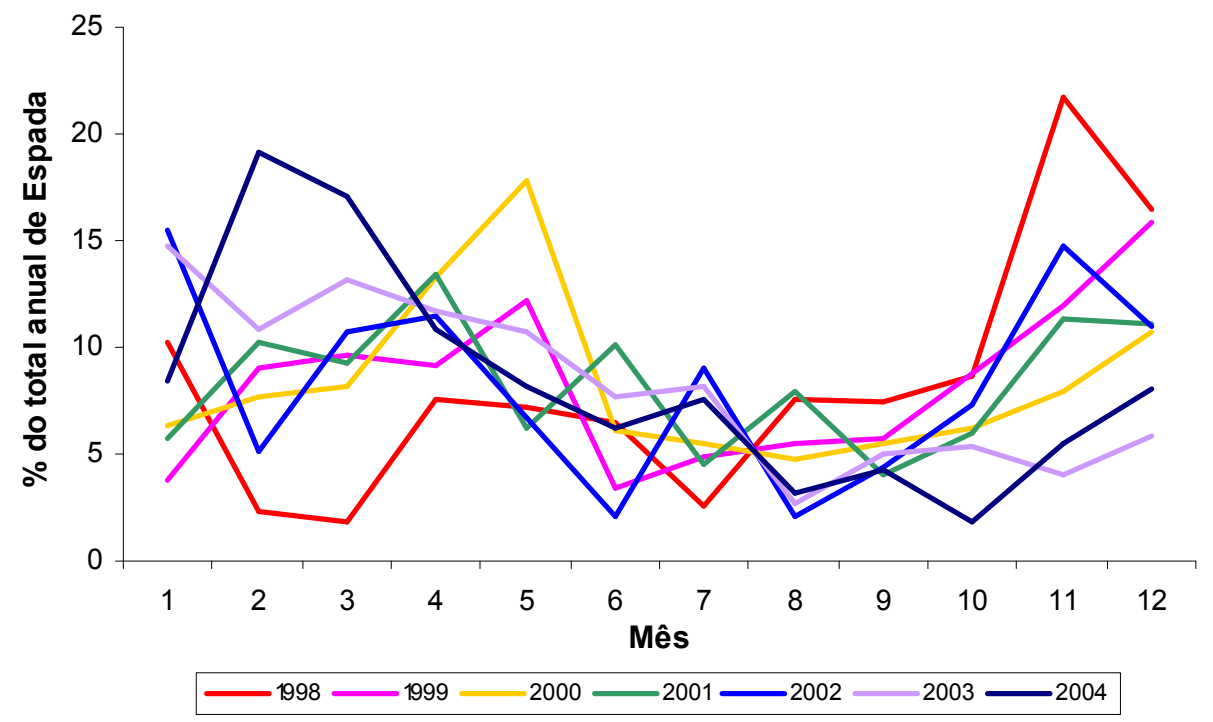

Figura 27: Proporções mensais de T. lepturus na captura anual da espécie desembarcada em São Paulo no período 1998-2004. 


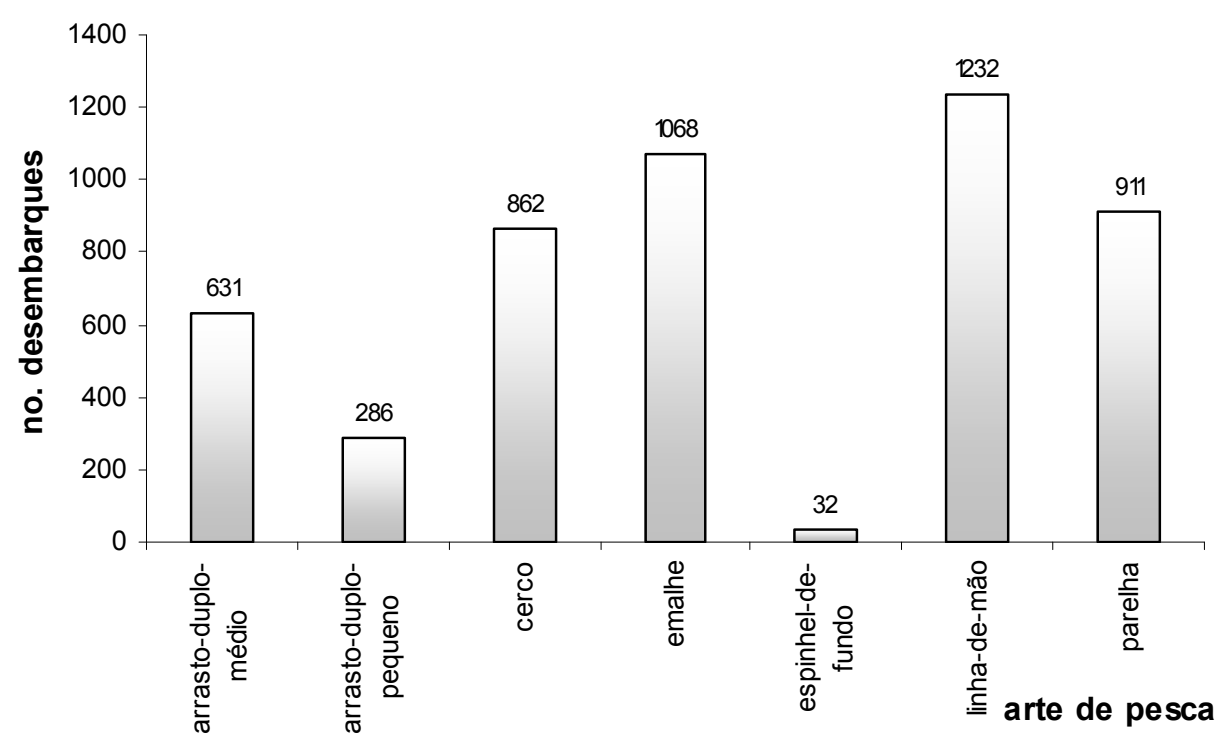

Figura 28: Número de desembarques realizados em São Paulo com presença de T. lepturus por arte de pesca no período de 1998-2004. Dados disponibilizados pelo Instituto de Pesca/APTA/SAA/SP.

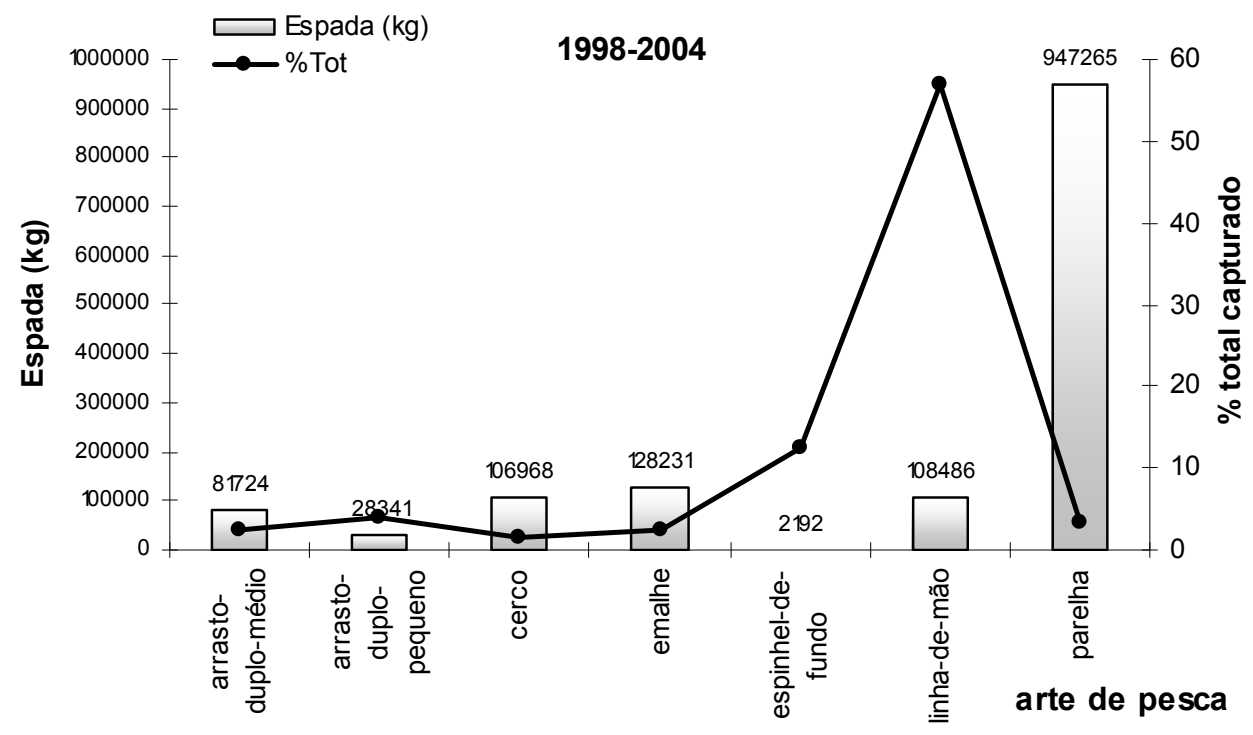

Figura 29: Captura (em kg) de T. lepturus em cada arte de pesca e respectivas porcentagens do total capturado em São Paulo no período de 1998-2004. 


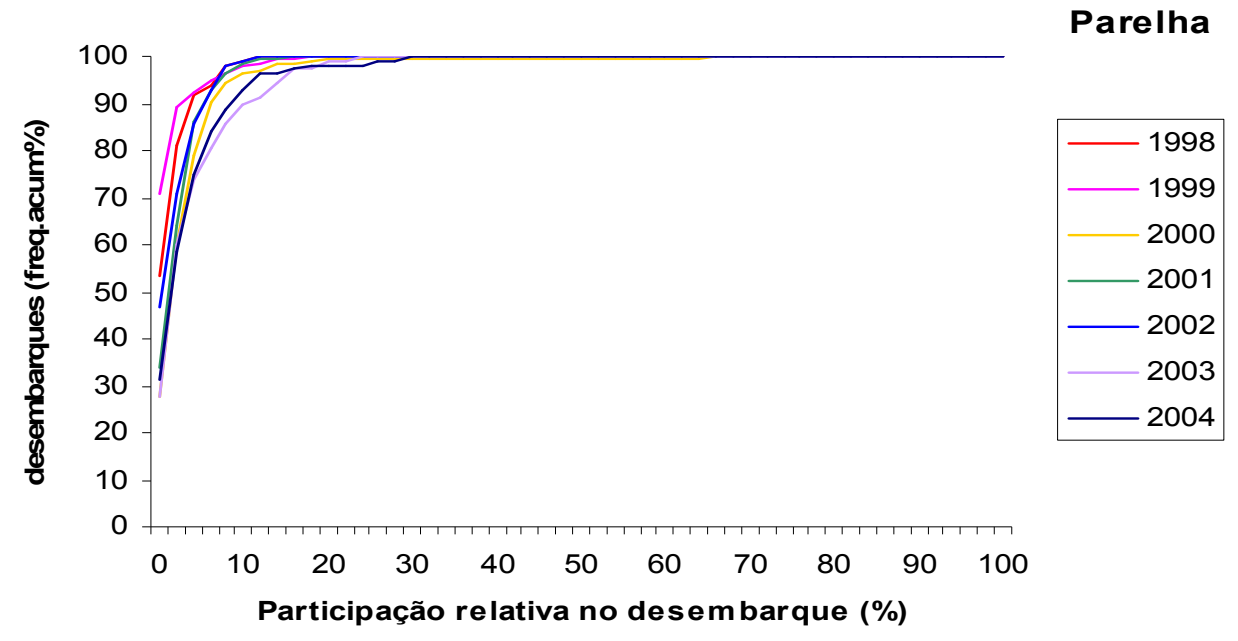

Figura 30: Participação relativa de T. lepturus por desembarque de pesca comercial de arrasto de fundo com parelhas efetuados em São Paulo no período de 1998-2004.

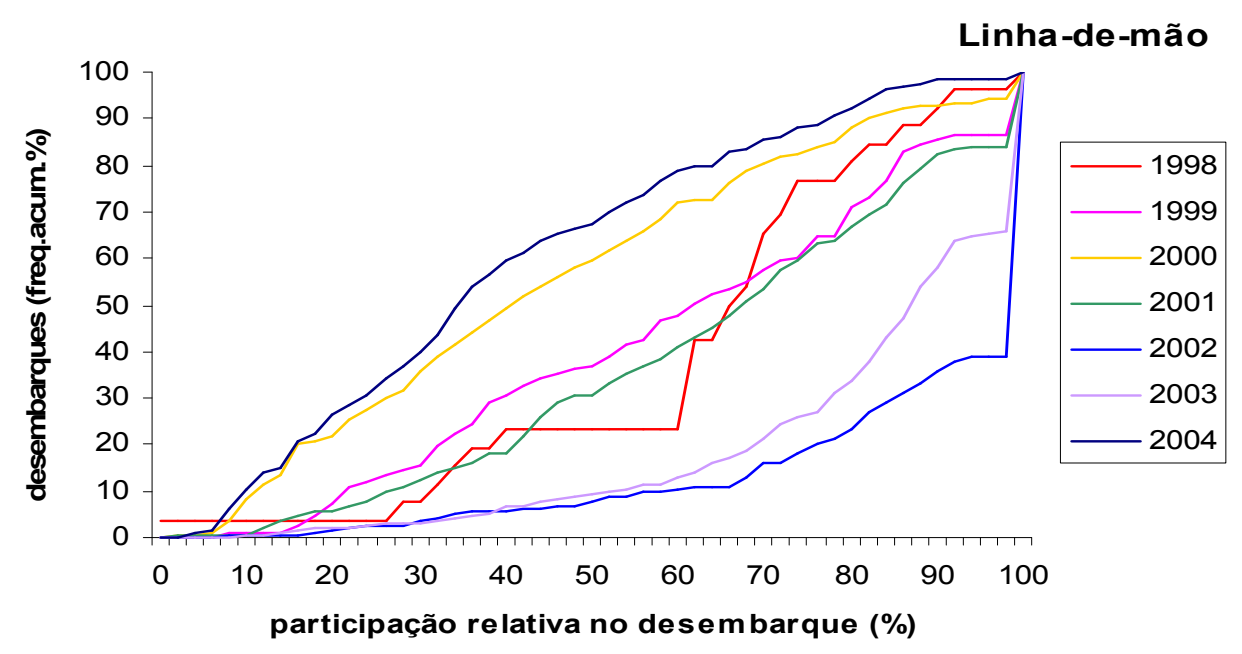

Figura 31: Participação relativa de T. lepturus por desembarque de pesca artesanal de linha-de-mão efetuados em São Paulo no período de 1998-2004. 


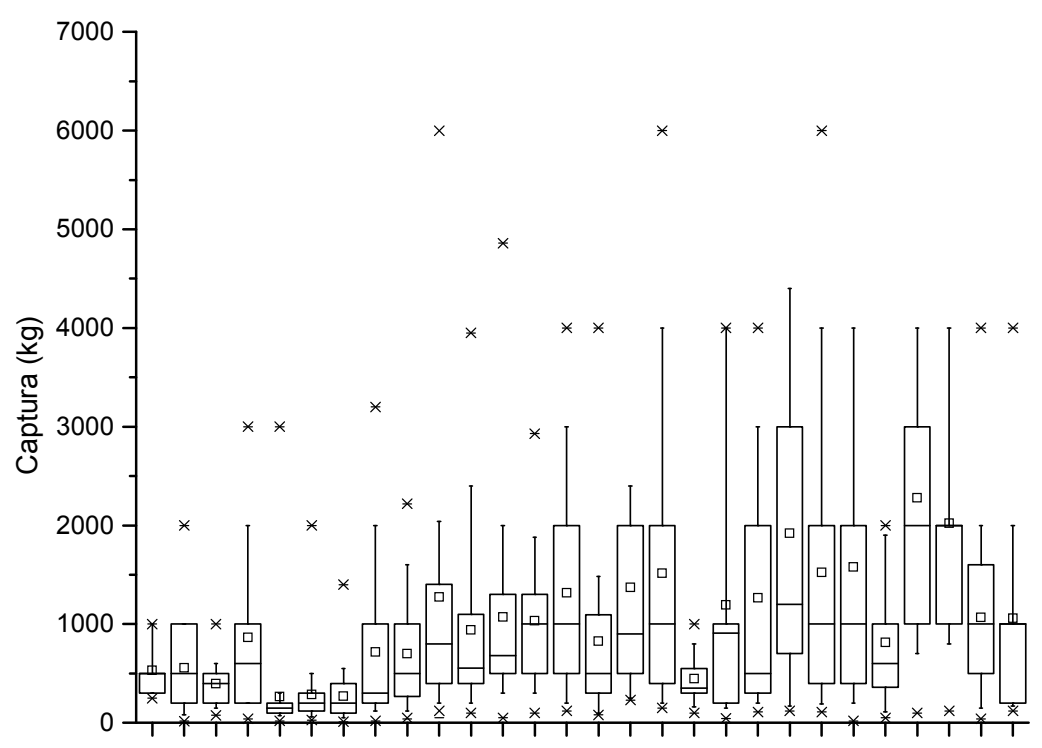

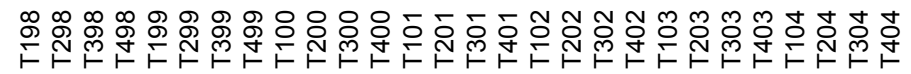

Trimestre/Ano

Figura 32: Boxplot das capturas trimestrais de T. lepturus provenientes da pesca de arrasto de fundo com parelhas em São Paulo no período de 1998 a 2004.

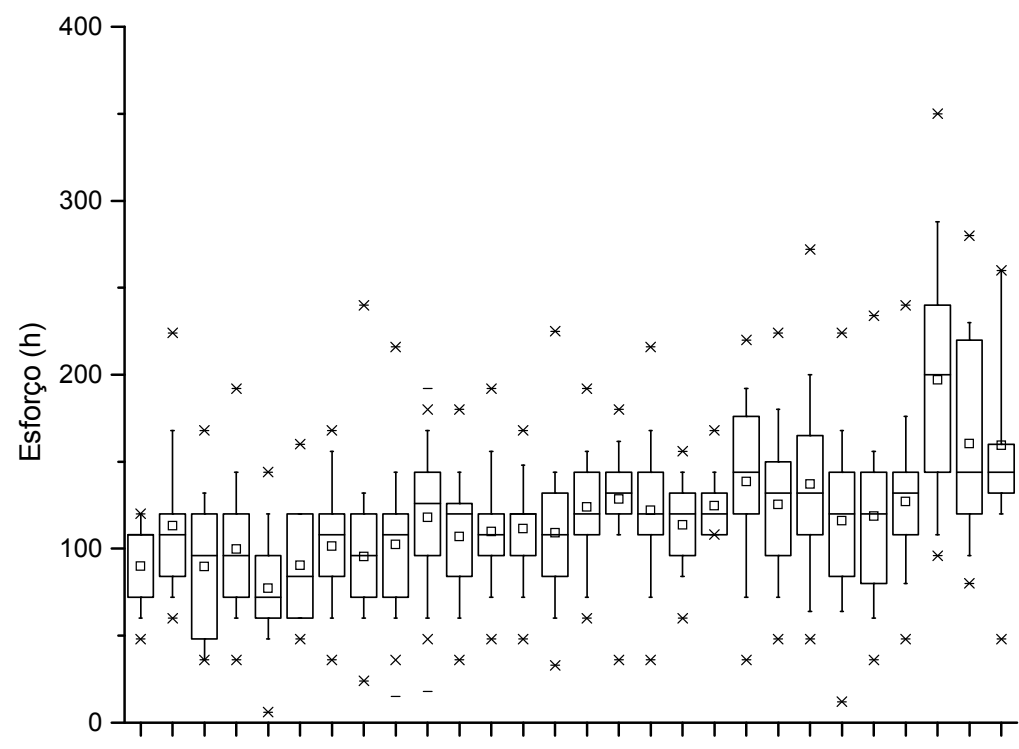

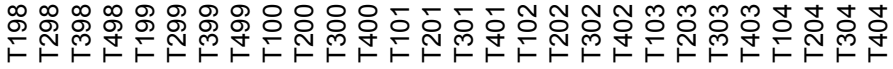

Trimestre/Ano

Figura 33: Boxplot do esforço de pesca trimestral aplicado nas operações de pesca de arrasto de fundo com parelhas em São Paulo que apresentaram T. lepturus no período de 1998 a 2004. 


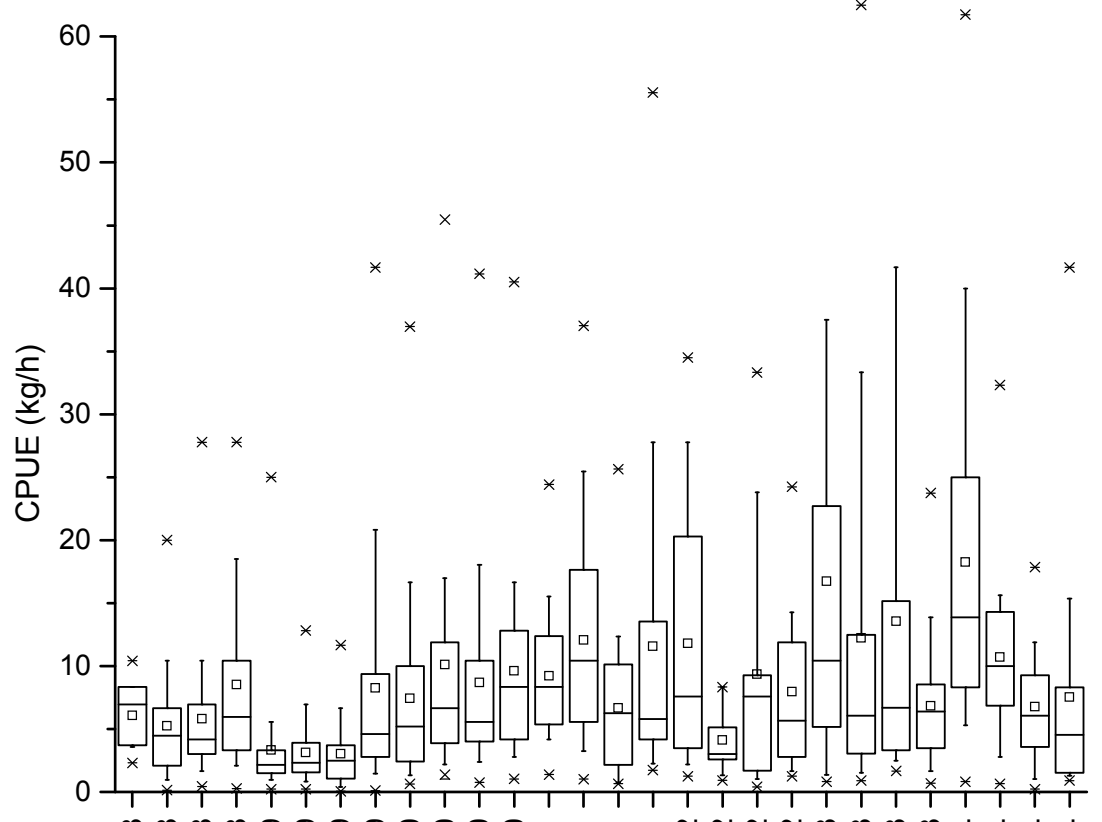

œ

Trimestre/Ano

Figura 34: Boxplot da CPUE trimestral de T. lepturus capturado na pesca de arrasto de fundo com parelhas em São Paulo no período de 1998 a 2004.

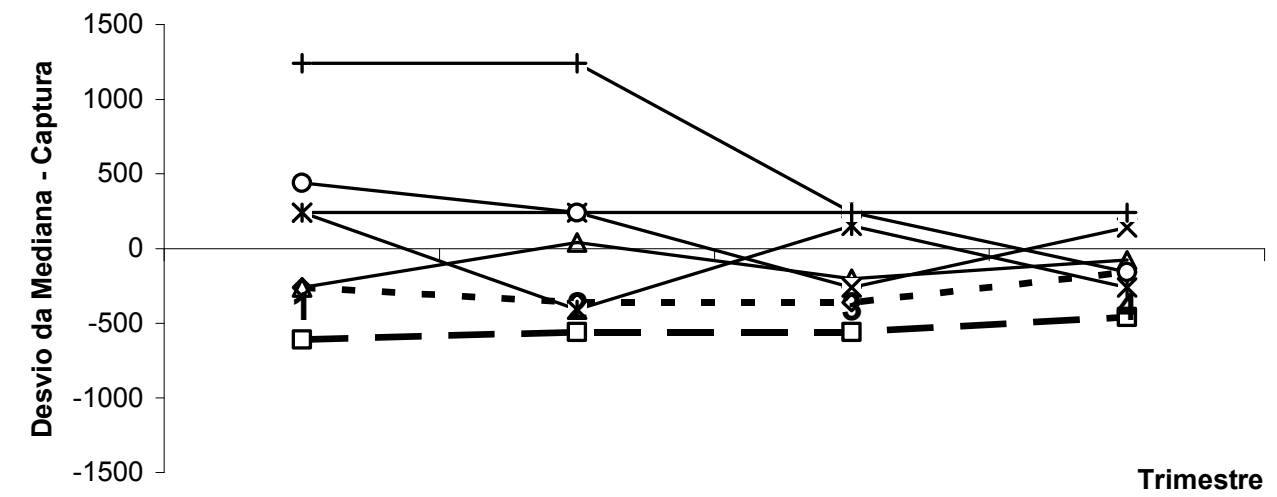

- $\diamond-1998 \longrightarrow \square-1999 \longrightarrow \Delta-2000 \longrightarrow x-2001-x-2002 \longrightarrow 0-2003 \longrightarrow$ - 2004

Figura 35: Variação trimestral da mediana das capturas de T. lepturus na pesca de arrasto de fundo com parelhas de São Paulo, em relação à sua média no período de 1998 a 2004. 


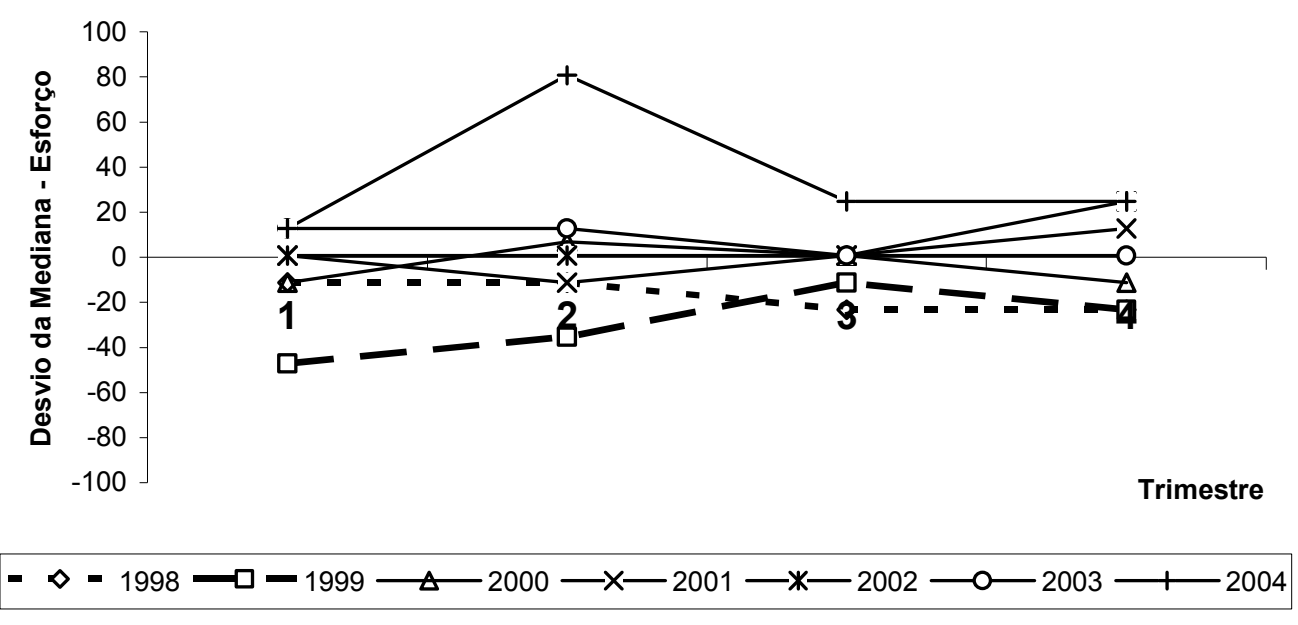

Figura 36: Variação trimestral da mediana do esforço de pesca aplicado trimestralmente na pesca de arrasto de fundo com parelhas de São Paulo que apresentaram T. lepturus, em relação à sua média no período de 1998 a 2004.

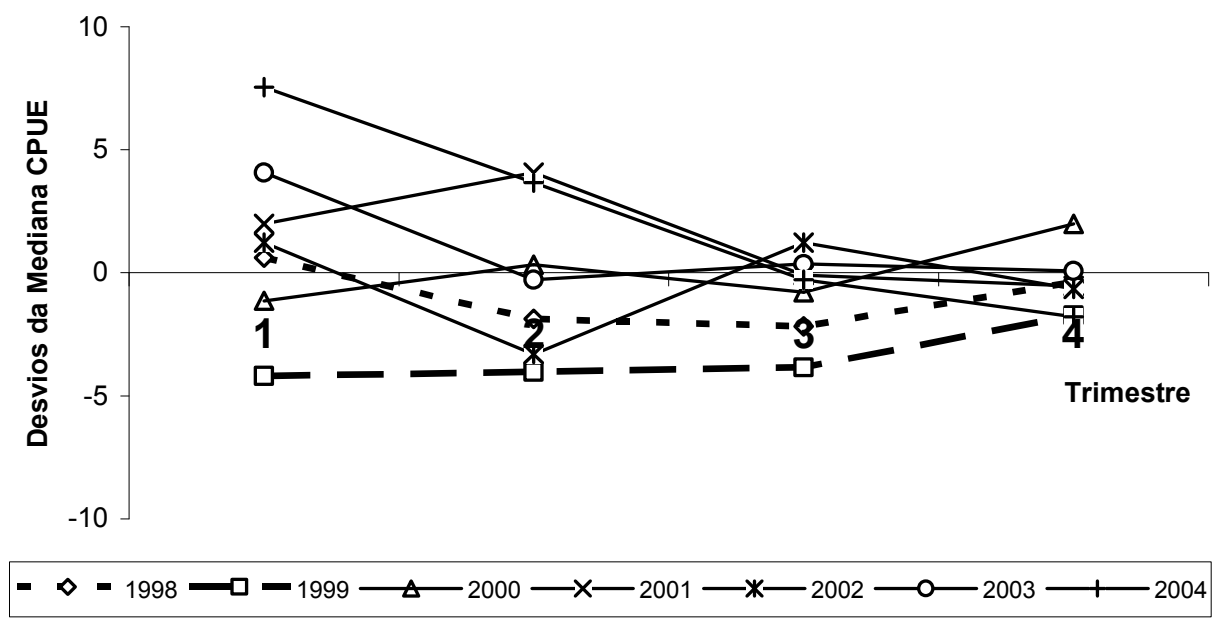

Figura 37: Variação trimestral da mediana da CPUE de T. lepturus na pesca de arrasto de fundo com parelhas de São Paulo, em relação à sua média no período de 1998 a 2004. 


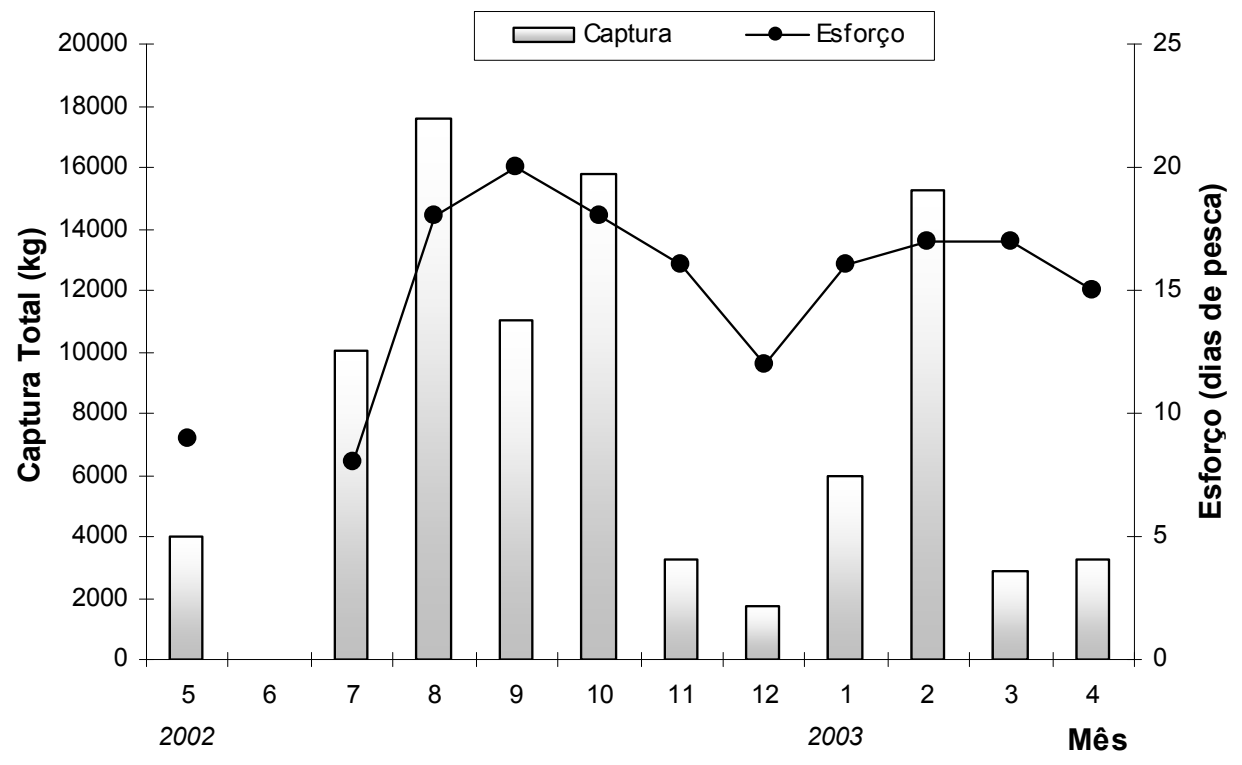

Figura 38: Produção mensal $(\mathrm{kg})$ e esforço de pesca (dias) dos cercos flutuantes situados nas praias de Caixa D'aço e Estaleiro, em Porto Belo (SC), de propriedade da Empresa Pioneira da Costa S.A., no período de maio de 2002 a abril de 2003.

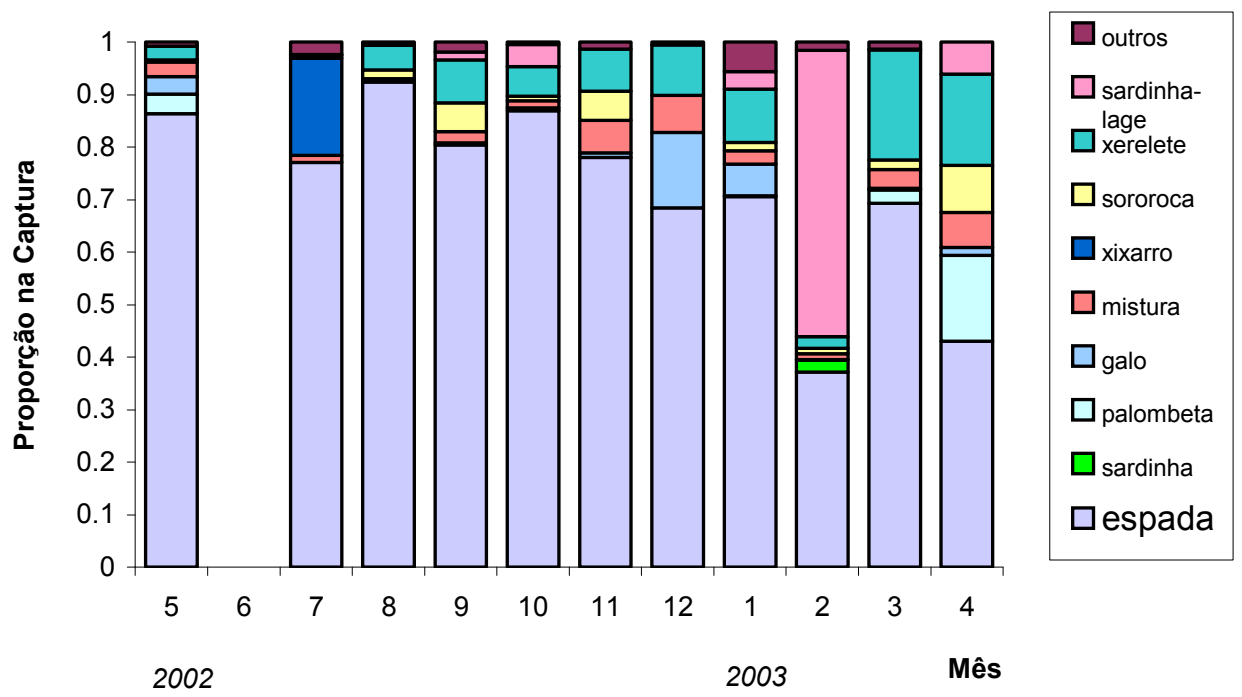

Figura 39: Proporção mensal das espécies capturadas nos cercos flutuantes situados nas praias de Caixa D’aço e Estaleiro, em Porto Belo (SC), de propriedade da Empresa Pioneira da Costa S.A., no período de maio de 2002 a abril de 2003. 


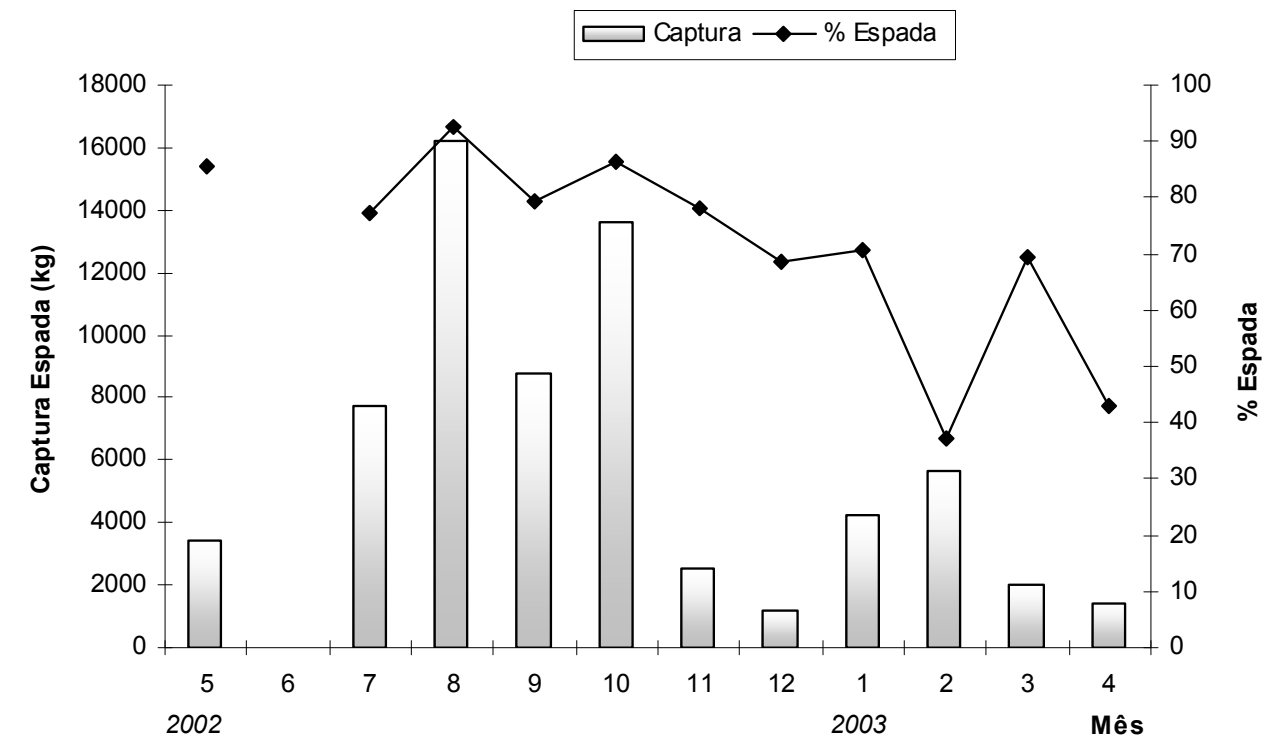

Figura 40: Produção mensal de T. lepturus $(\mathrm{kg})$ e proporção da espécie na captura total obtida nos cercos flutuantes situados nas praias de Caixa D'aço e Estaleiro, em Porto Belo (SC), de propriedade da Empresa Pioneira da Costa S.A., no período de maio de 2002 a abril de 2003.

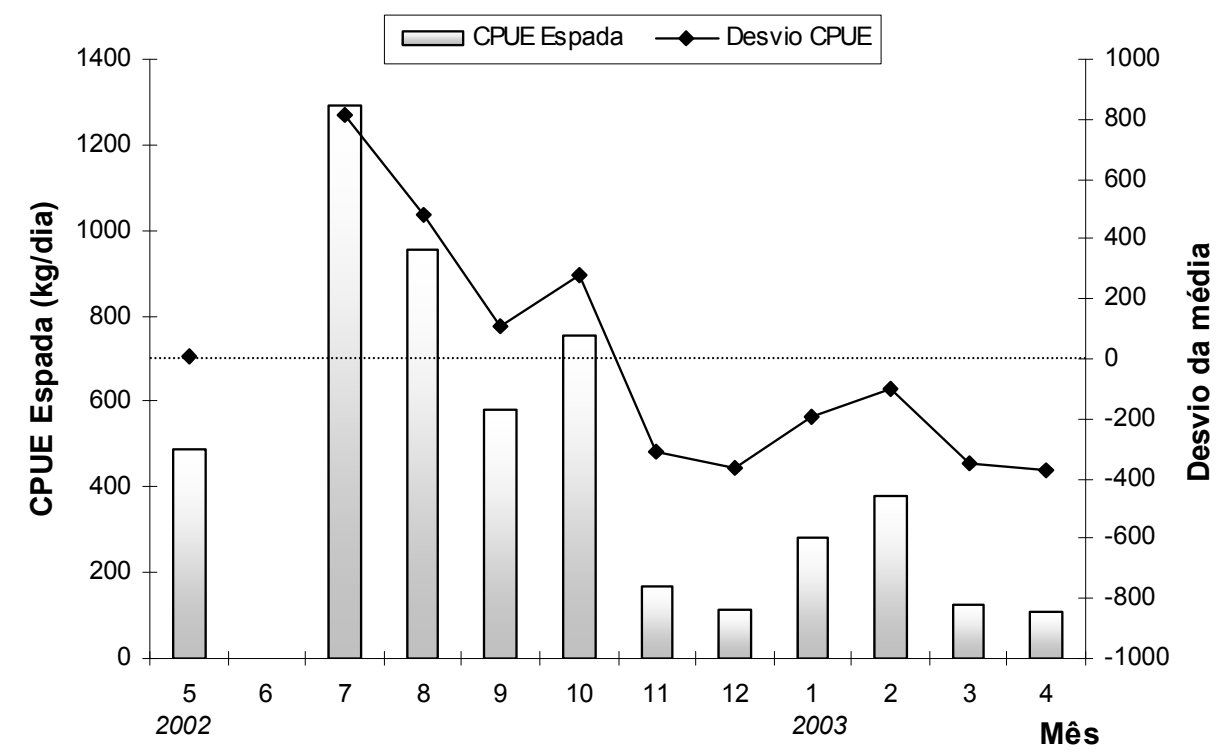

Figura 41: Captura por umidade de esforço (CPUE - kg/dia) e respectivas variações da média do período dos cercos flutuantes situados nas praias de Caixa D'aço e Estaleiro, em Porto Belo (SC), de propriedade da Empresa Pioneira da Costa S.A., no período de maio de 2002 a abril de 2003. 


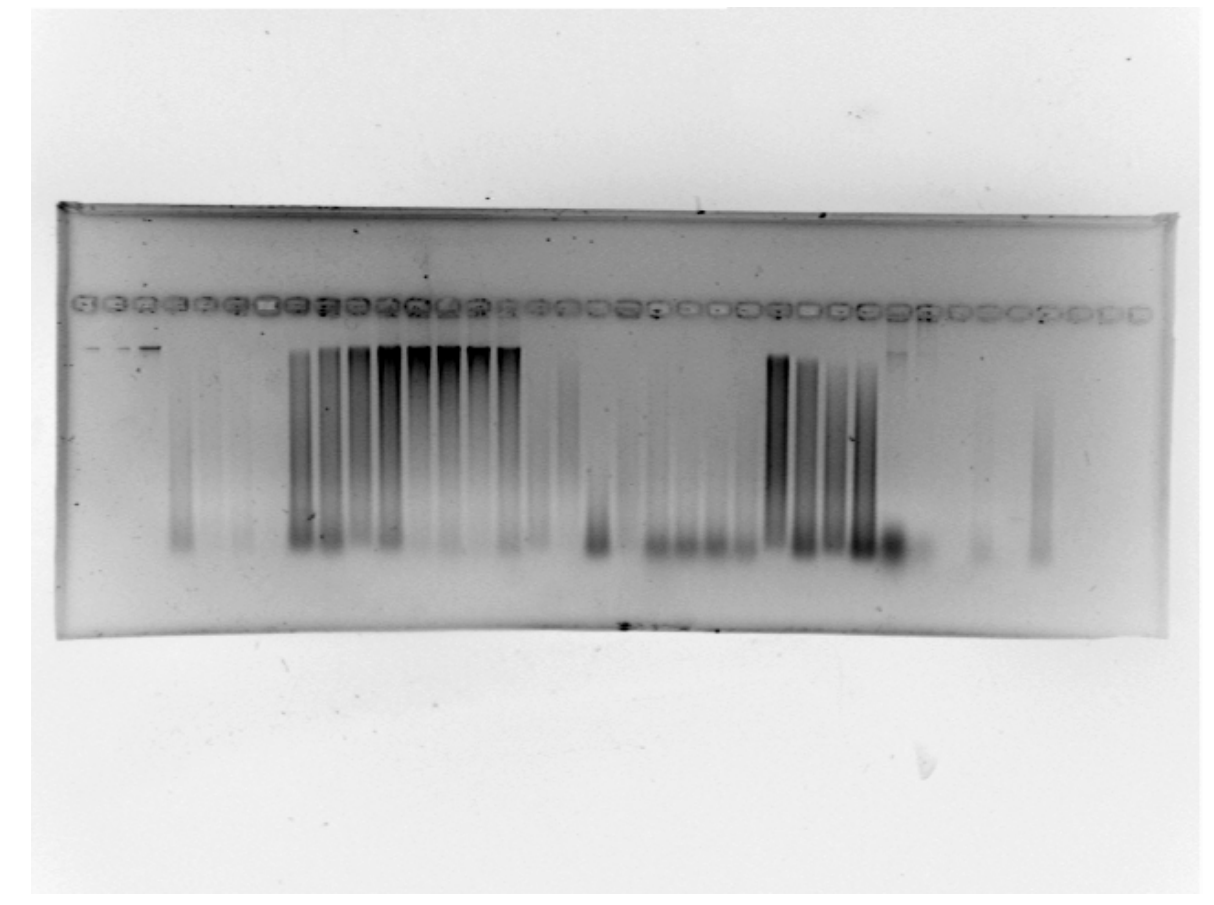

Figura 42: Extração de várias amostras de DNA de T. lepturus, apresentando os rastros de degradação do DNA a diferentes concentrações. 


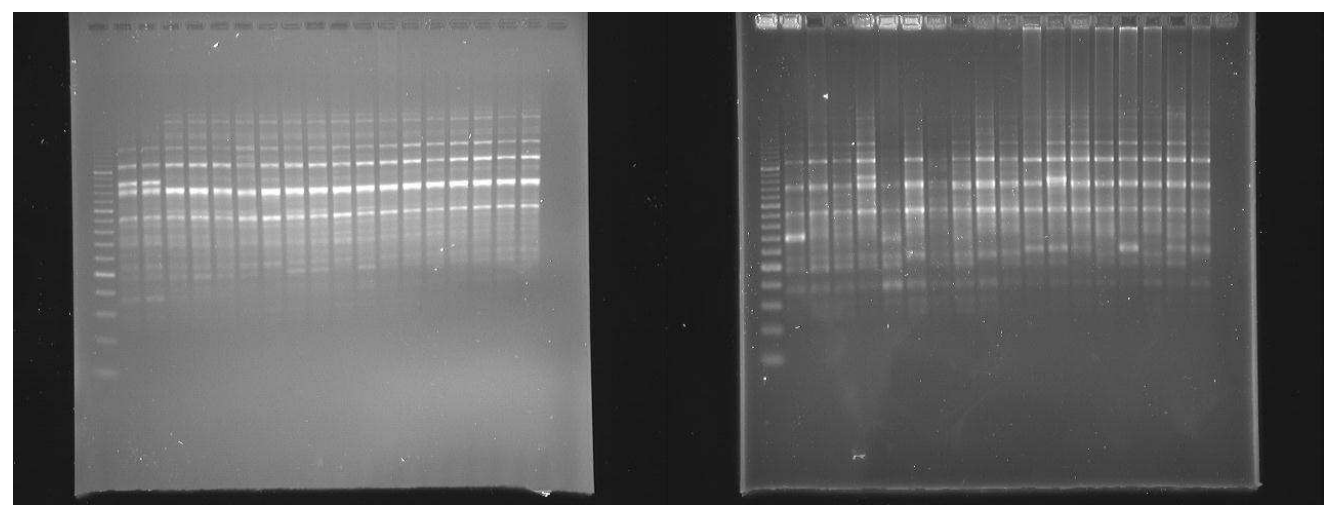

RJ

SP

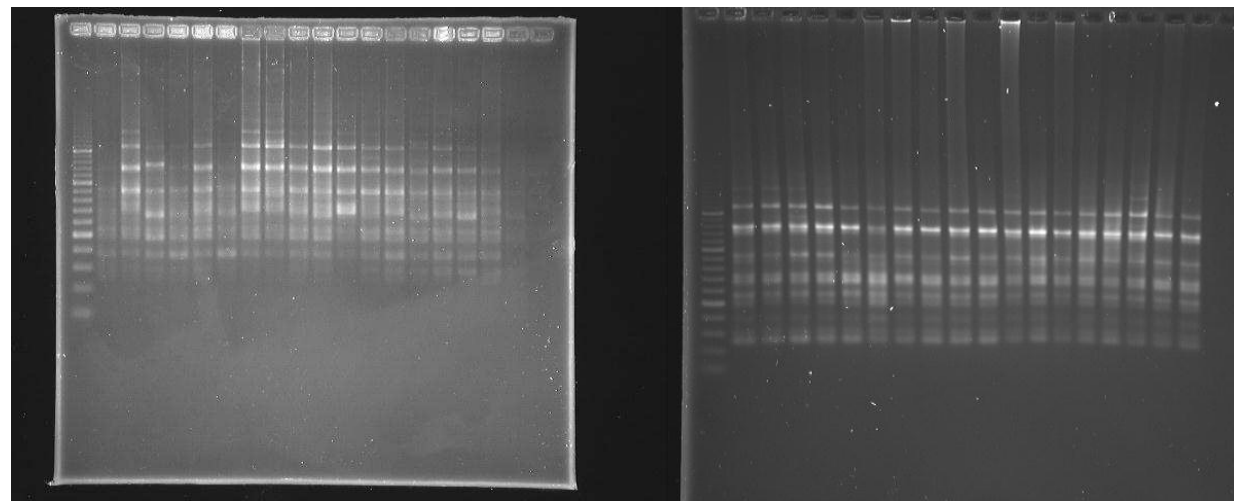

$\mathrm{SC}$

RS

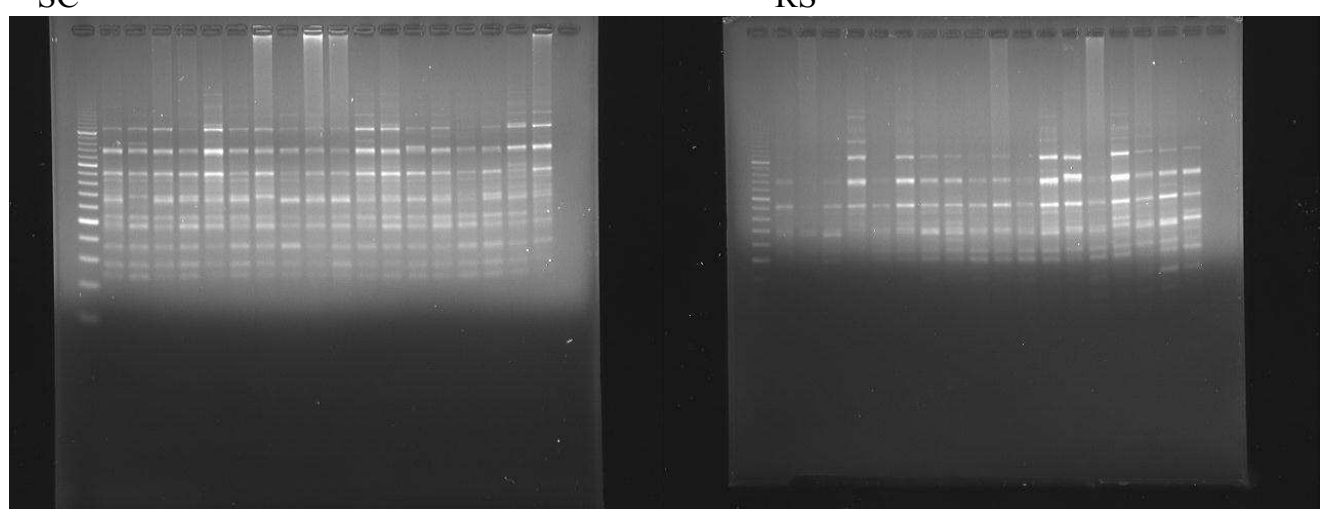

Figura 43: Eletroforese das amplificações RAPD-PCR das amostras de DNA de tecido muscular de $T$, lepturus, com o primer Primer 01, nos Estados do Pará, Rio Grande do Norte e Rio de Janeiro, São Paulo, Santa Catarina e Rio Grande do Sul. 


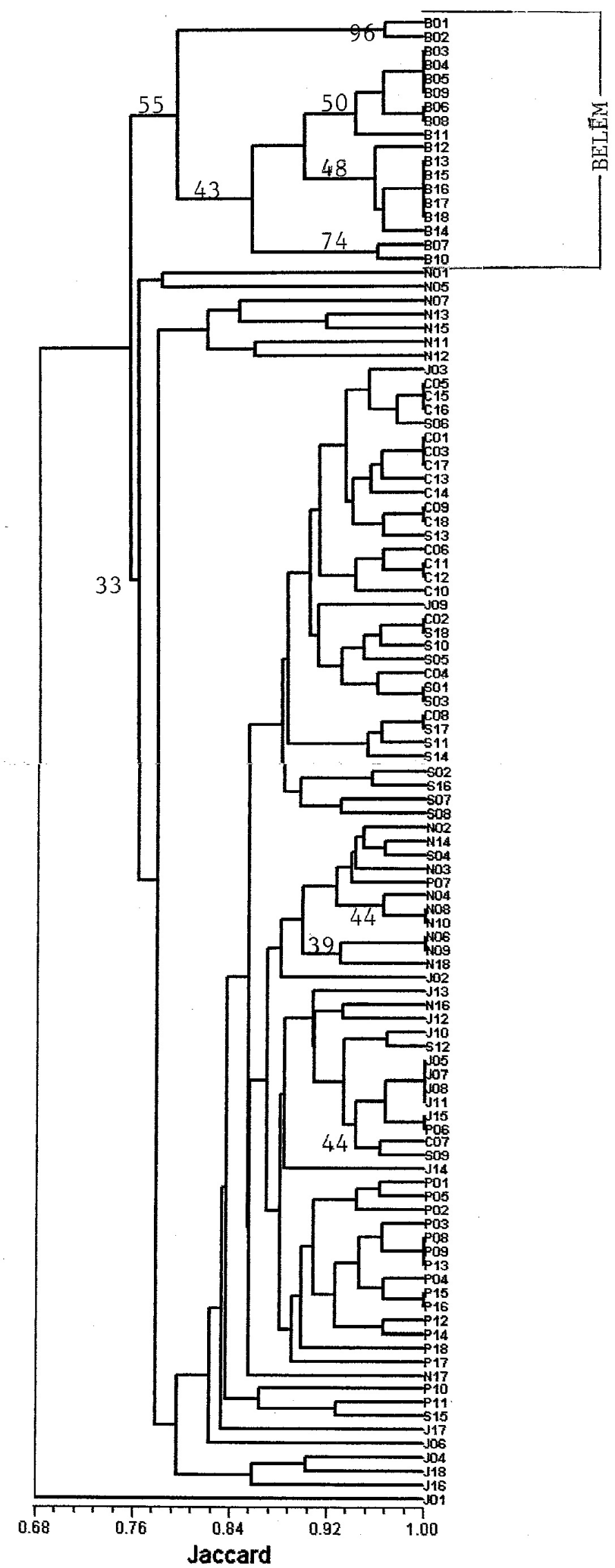

Figura 44 - Dendrograma de similaridade genética com o coeficiente de Jaccard e algoritmo UPGMA obtido para as amostras de T. lepturus das seis regiões analisadas. Valores de bootstrap maiores que 30 estão apresentados junto aos seus respectivos nós. 


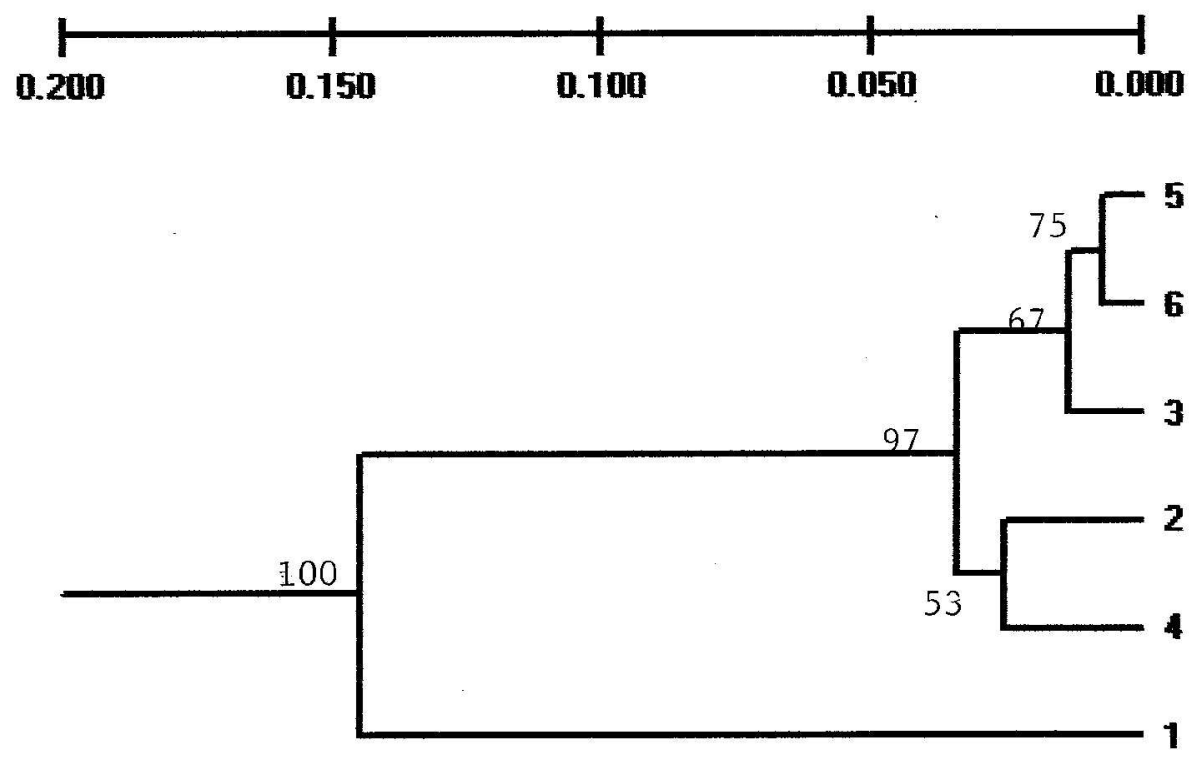

Figura 45: Dendrograma de distâncias genéticas de Ney (1978) e algoritmo UPGMA obtido para $T$. lepturus em cada região. 1 - Belém (PA), 2 - Natal (RN), 3 - Arraial do Cabo (RJ), 4 Guarujá (SP), 5 - Porto Belo (SC), 6 - Rio Grande (RS). Valores de bootstrap estão apresentados junto aos seus respectivos nós. 


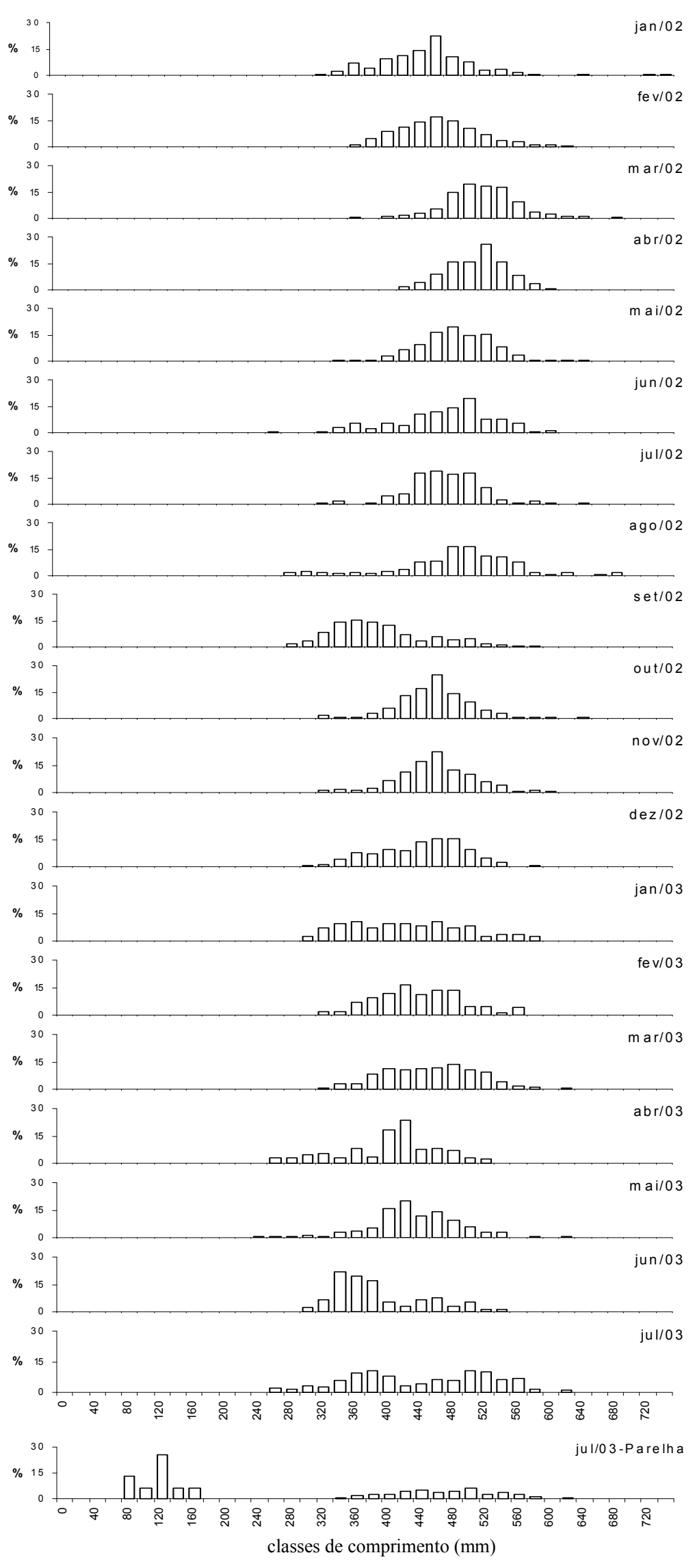

Figura 46 - Distribuição mensal de freqüências relativas de comprimento anal dos exemplares Trichiurus lepturus amostrados em Arraial do Cabo (RJ). 


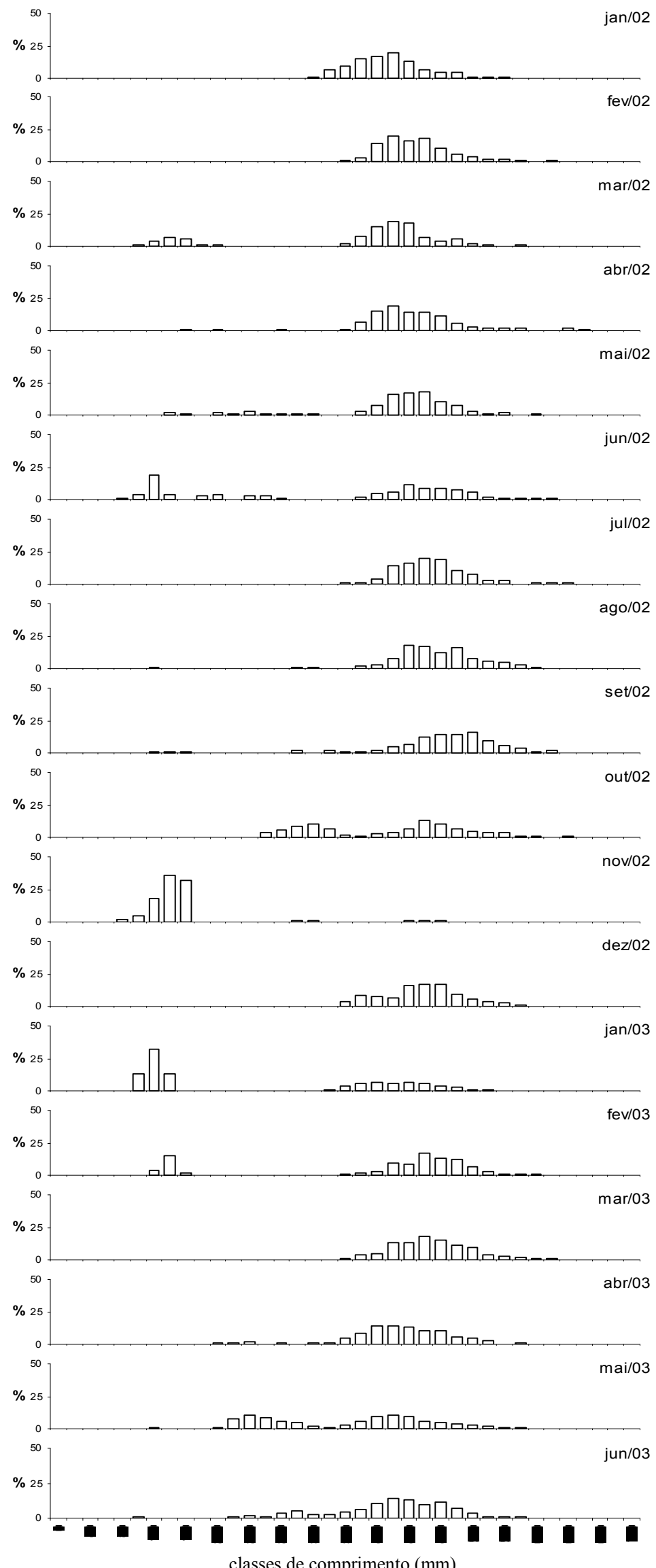

Figura 47 - Distribuição mensal de freqüências relativas de comprimento anal dos exemplares Trichiurus lepturus amostrados em Guarujá (SP). 


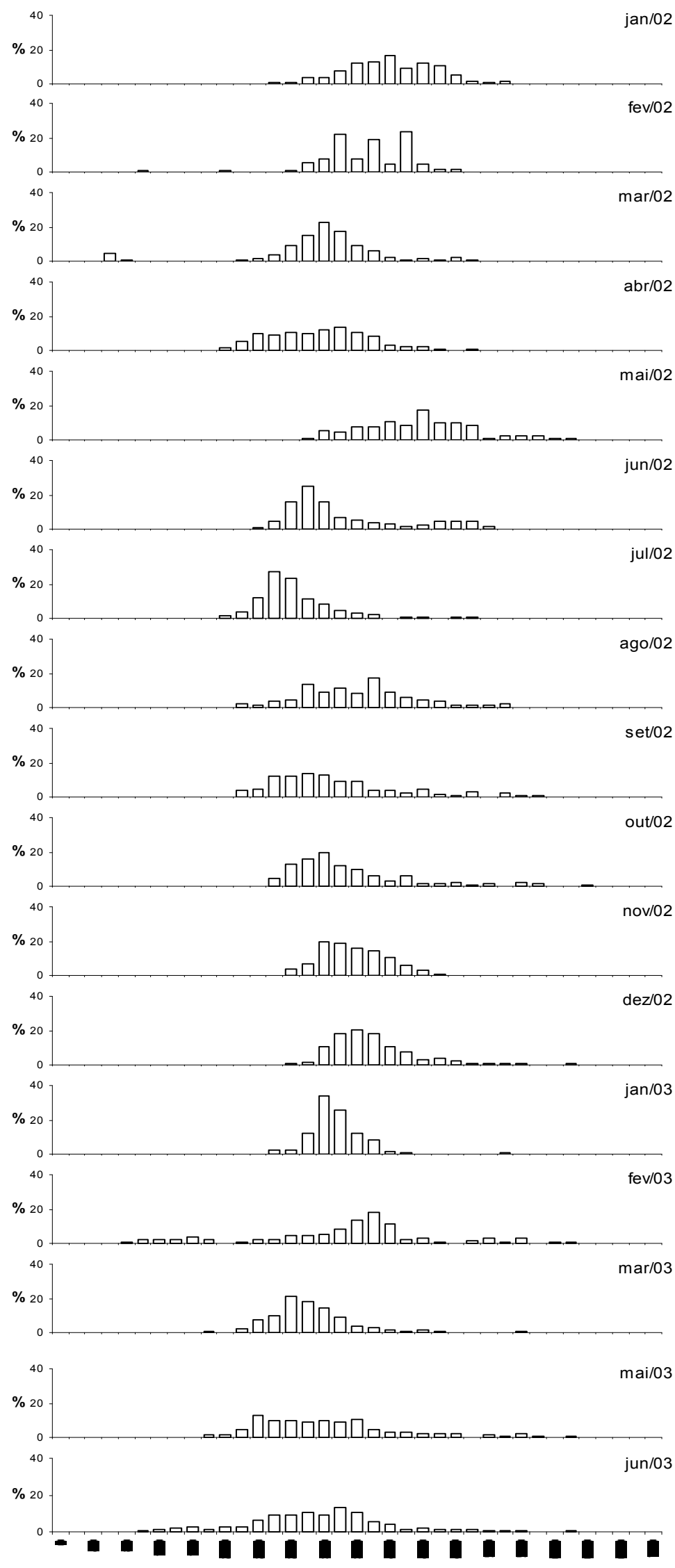

classes de comprimento (mm)

Figura 48 - Distribuição mensal de freqüências relativas de comprimento anal dos exemplares Trichiurus lepturus amostrados em Porto Belo e Florianópolis (SC). 


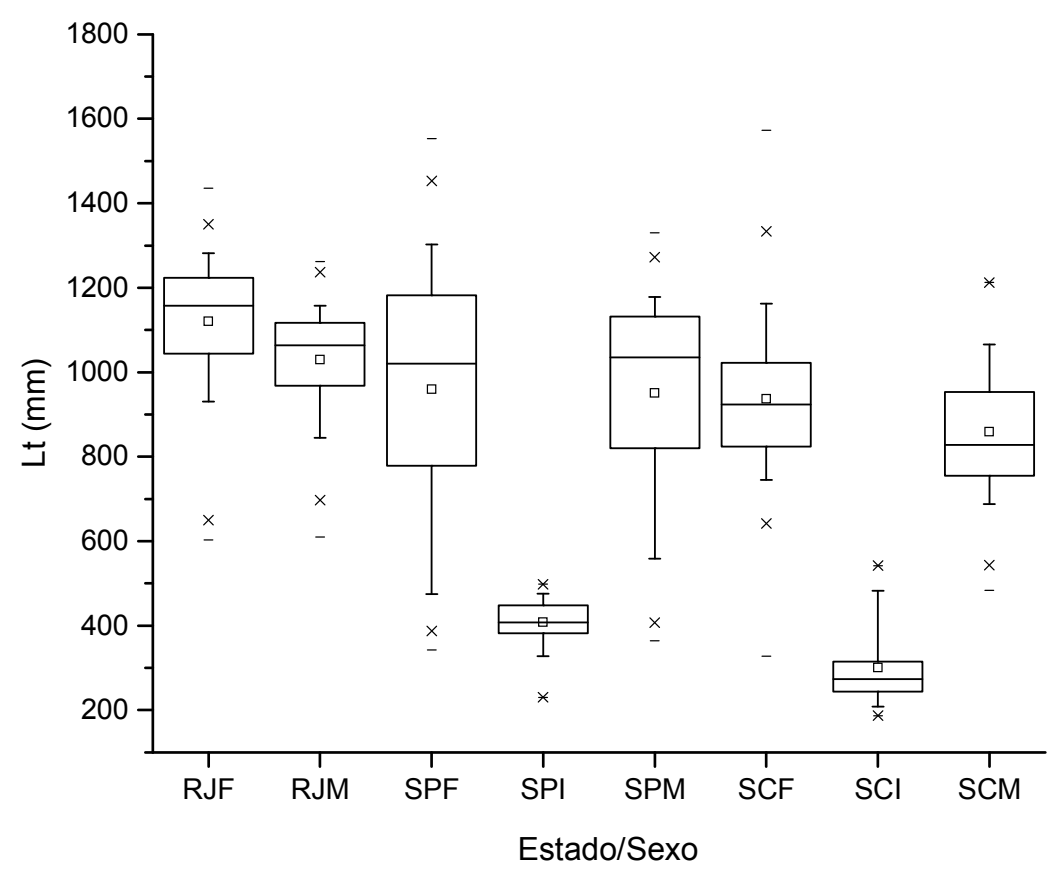

Figura 49: Boxplot dos comprimentos totais $(\mathrm{Lt}-\mathrm{mm})$ de $T$. lepturus por sexo de cada região estudada. RJF e RJM - fêmeas e machos do Rio de Janeiro; SPF, SPI e SPM - fêmeas, indeterminados e machos de São Paulo; SCF, SCI e SCM - fêmeas, indeterminados e machos de Santa Catarina

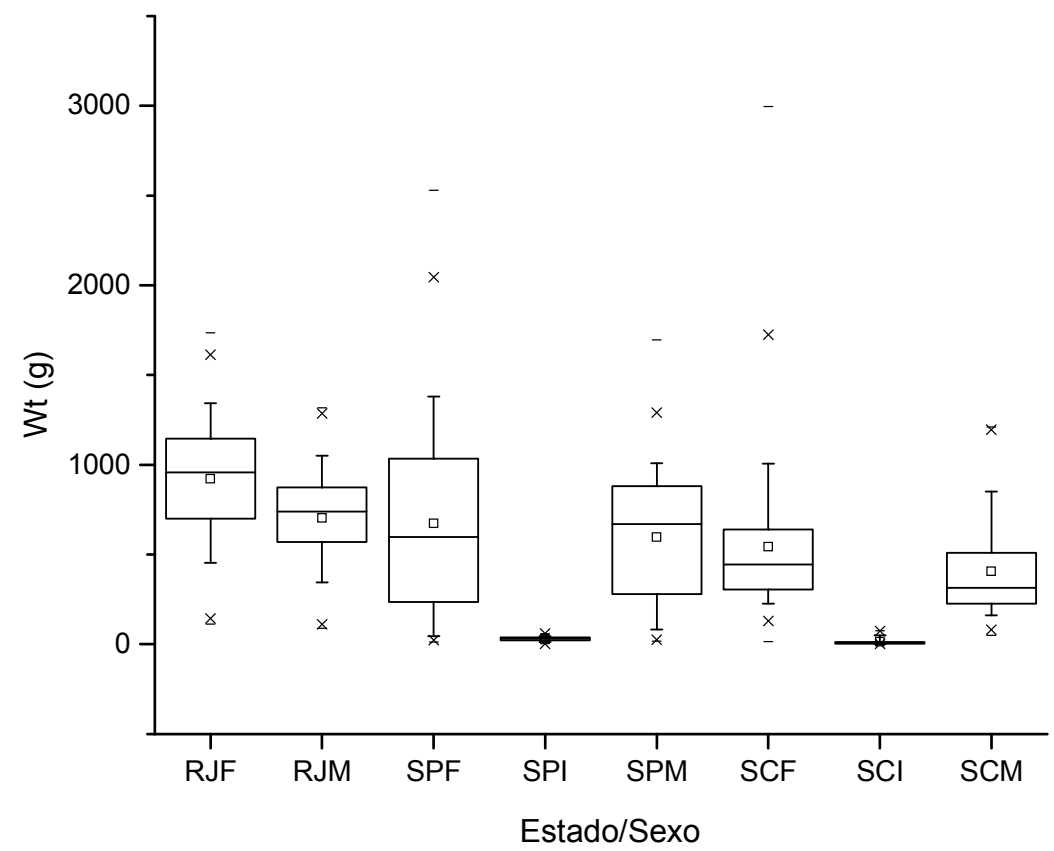

Figura 50: Boxplot dos pesos totais (Wt - g) de T. lepturus por sexo de cada região estudada. RJF e RJM - fêmeas e machos do Rio de Janeiro; SPF, SPI e SPM - fêmeas, indeterminados e machos de São Paulo; SCF, SCI e SCM - fêmeas, indeterminados e machos de Santa Catarina 

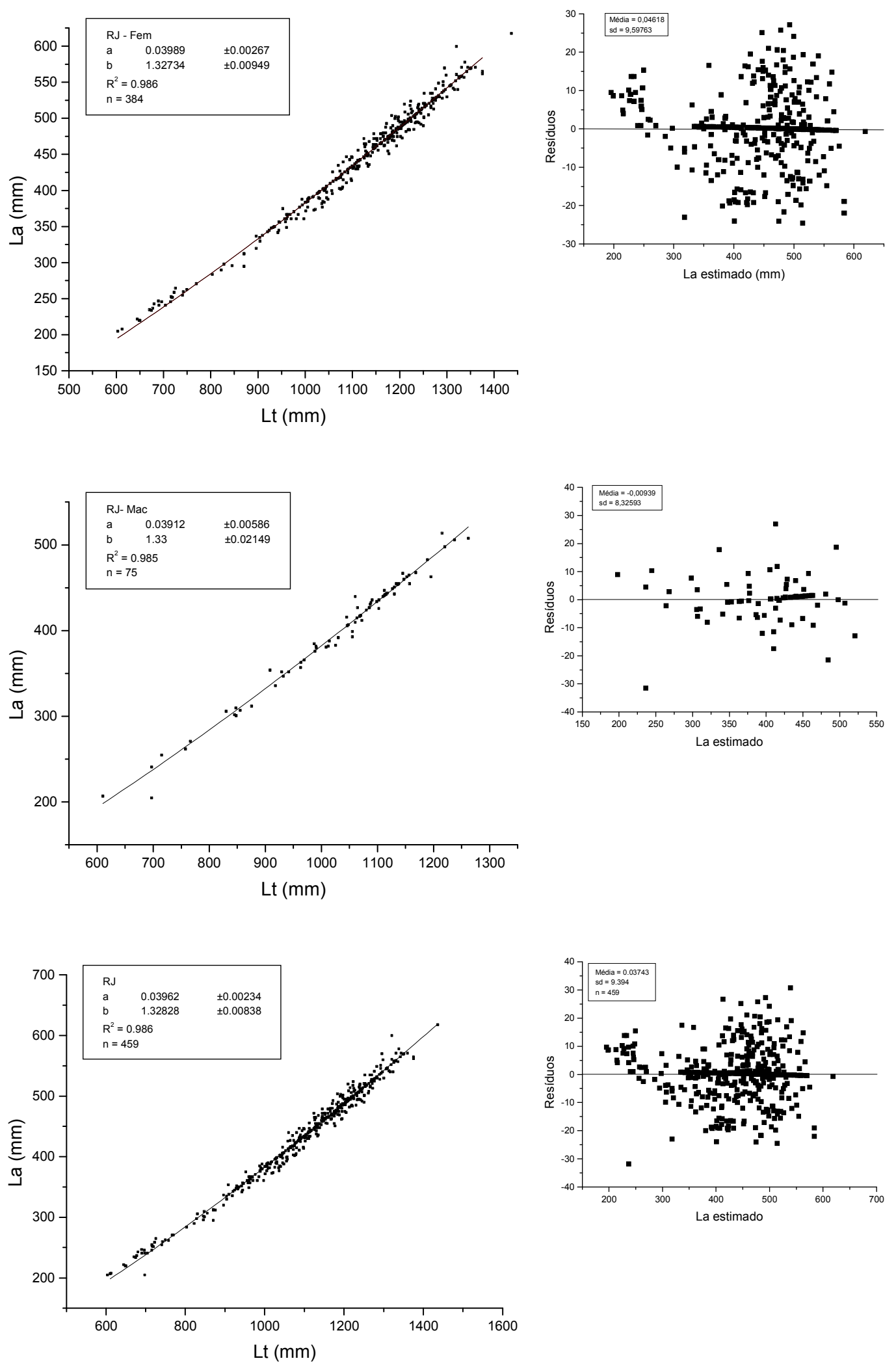

Figura 51: Relações entre o comprimento anal e comprimento total dos exemplares fêmeas (RJ -Fem), machos (RJ - Mac) e sexos agrupados (RJ) de T. lepturus da região de Arraial do Cabo (RJ), e seus respectivos diagramas de dispersão de resíduos. 

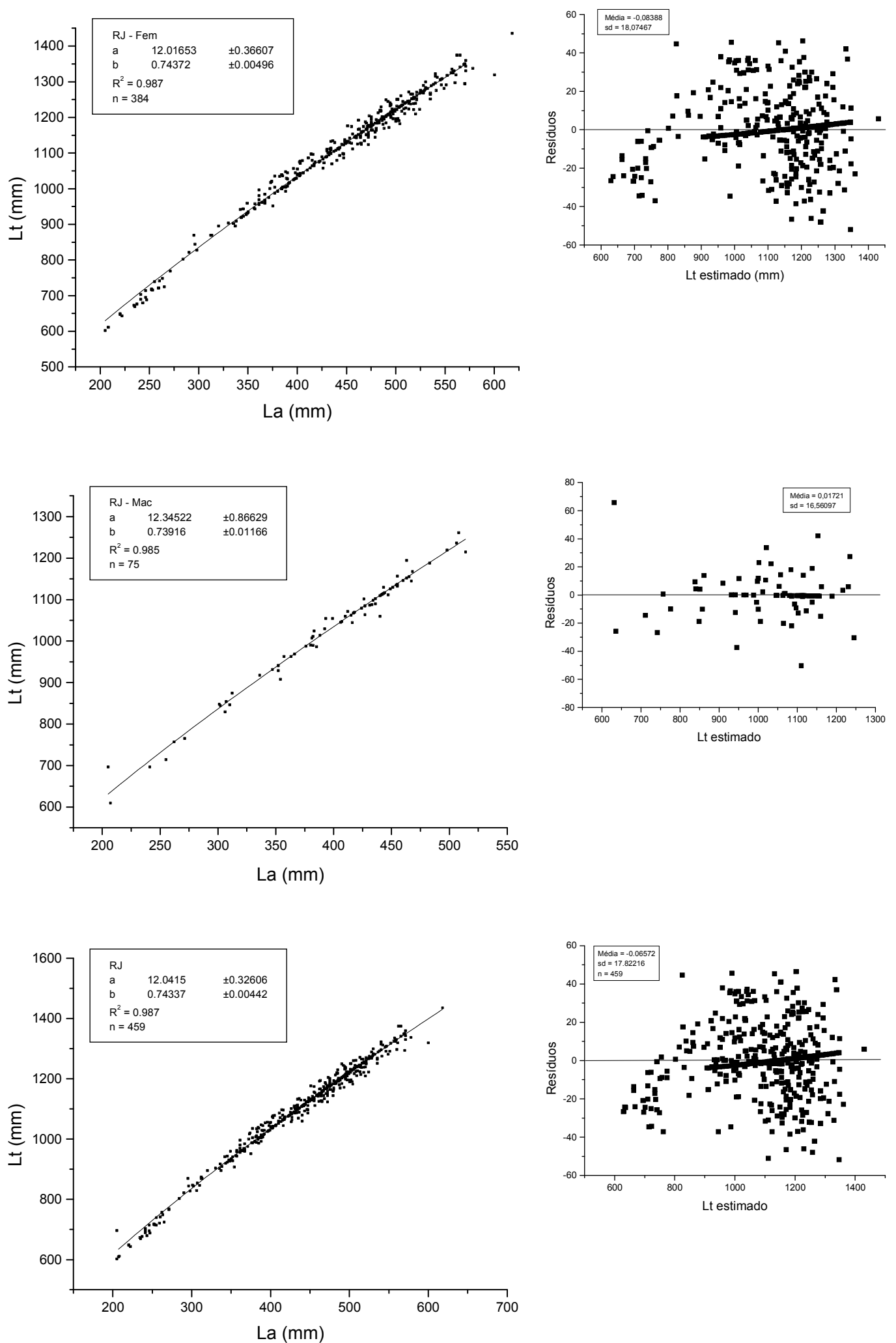

Figura 52: Relações entre o comprimento total e comprimento anal dos exemplares fêmeas (RJ -Fem), machos (RJ - Mac) e sexos agrupados (RJ) de T. lepturus da região de Arraial do Cabo (RJ), e seus respectivos diagramas de dispersão de resíduos. 

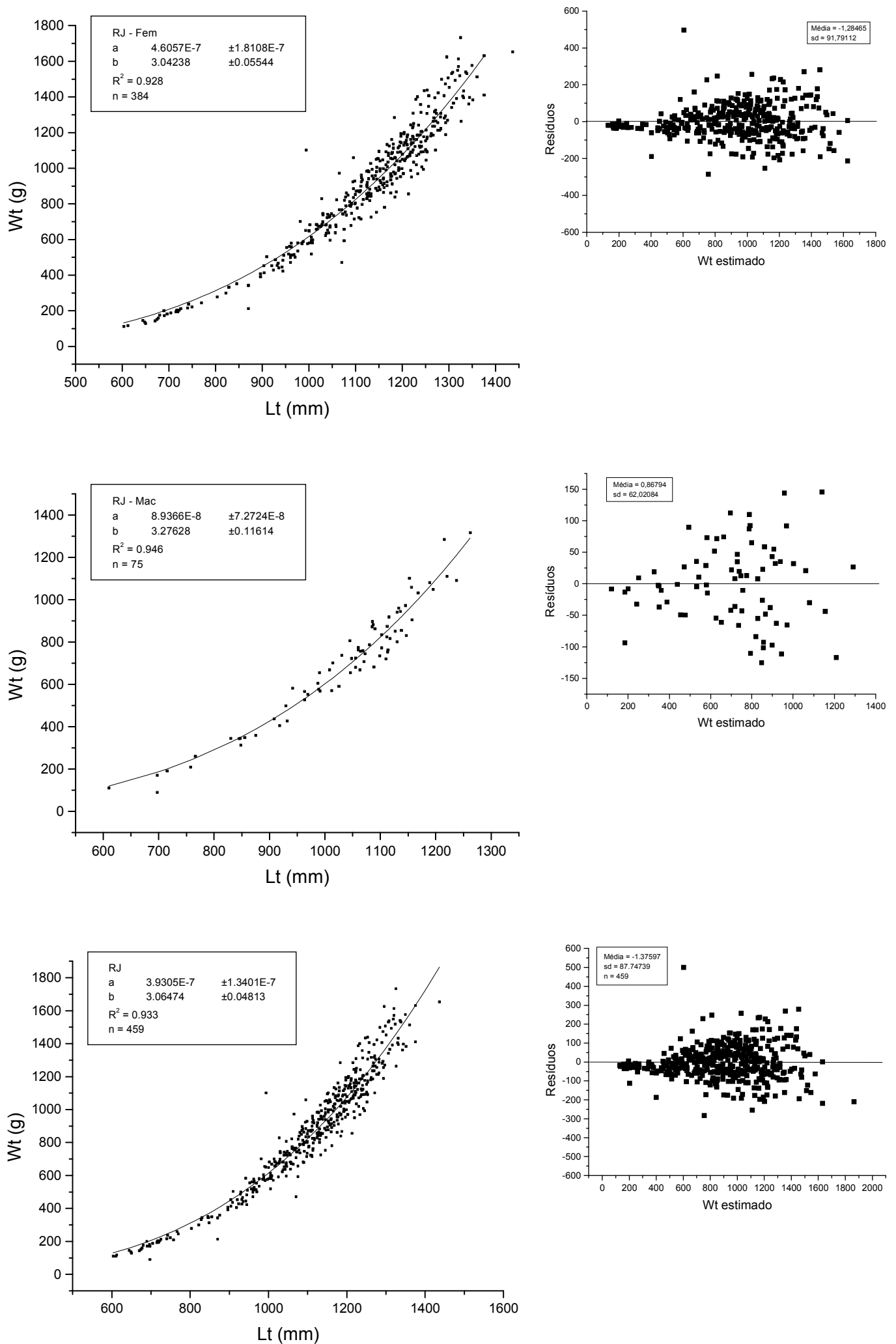

Figura 53: Relações entre o peso total e comprimento total dos exemplares fêmeas (RJ -Fem), machos (RJ - Mac) e sexos agrupados (RJ) de T. lepturus da região de Arraial do Cabo (RJ), e seus respectivos diagramas de dispersão de resíduos. 

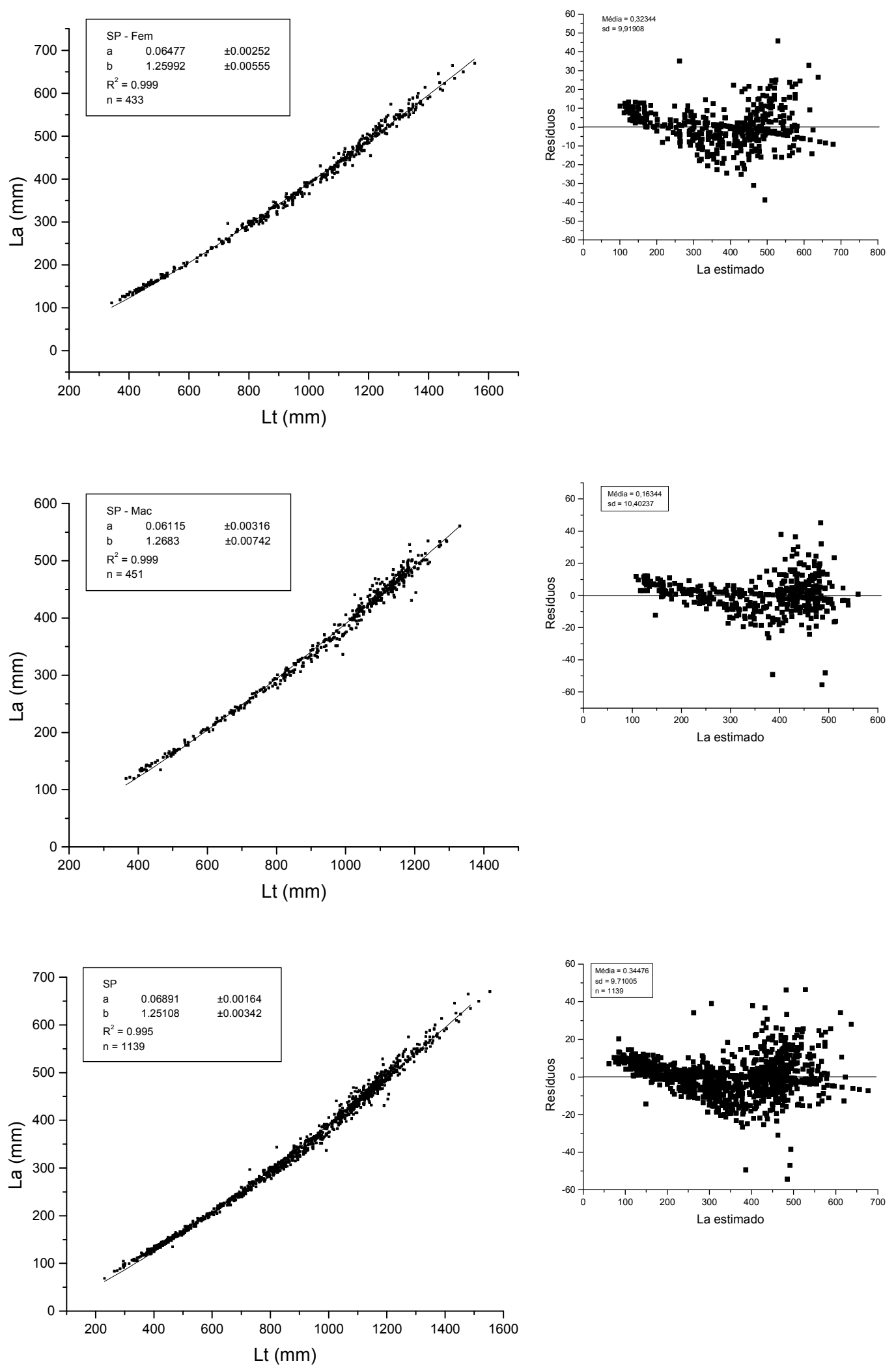

Figura 54: Relações entre o comprimento anal e comprimento total dos exemplares fêmeas ( $\mathrm{SP}$-Fem), machos (SP - Mac) e sexos agrupados (SP) de T. lepturus da costa de São Paulo, e seus respectivos diagramas de dispersão de resíduos. 

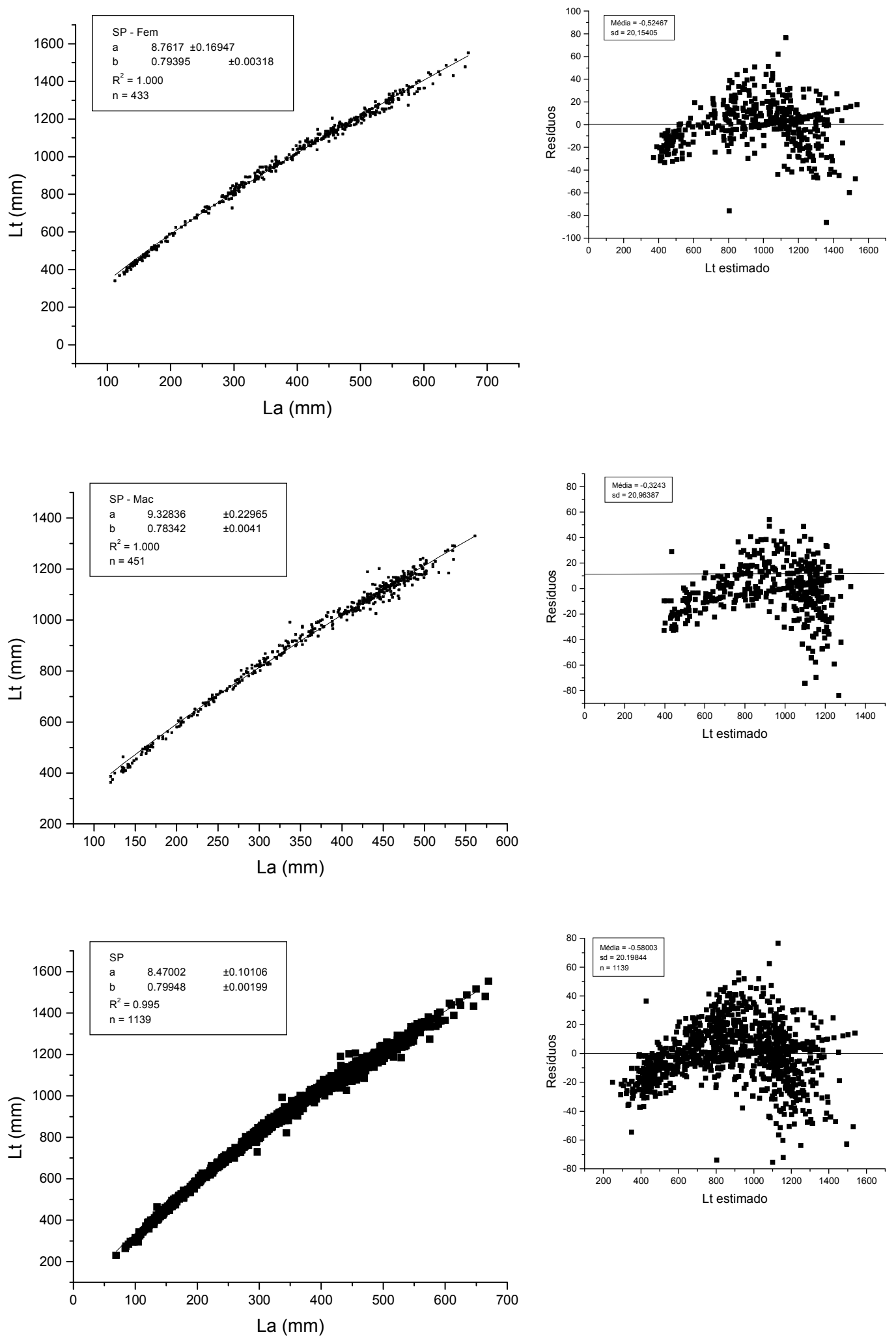

Figura 55: Relações entre o comprimento total e comprimento anal dos exemplares fêmeas ( $\mathrm{SP}$-Fem), machos (SP - Mac) e sexos agrupados (SP) de T. lepturus da costa de São Paulo, e seus respectivos diagramas de dispersão de resíduos. 

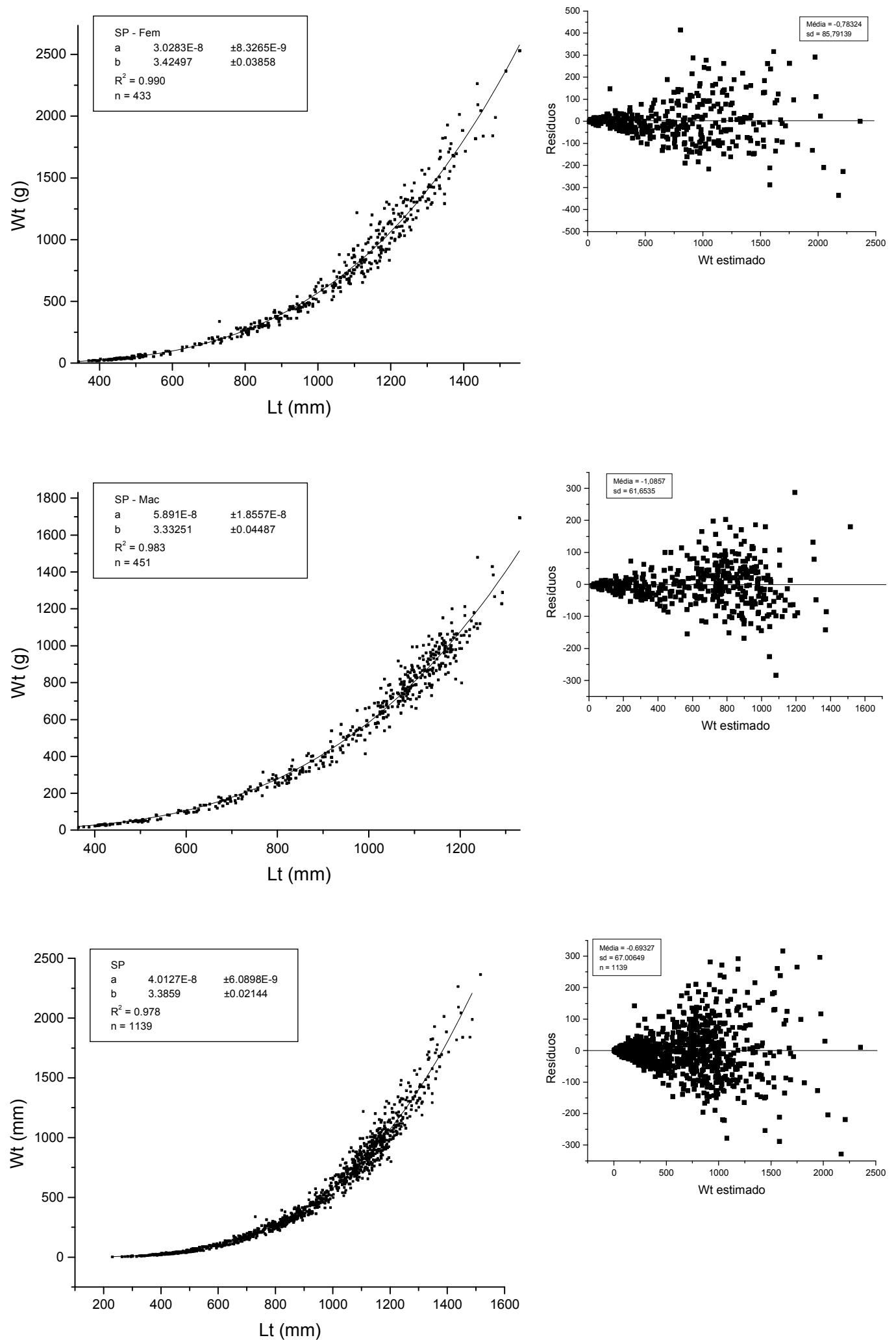

Figura 56: Relações entre o peso total e comprimento total dos exemplares fềmeas (SP -Fem), machos (SP - Mac) e sexos agrupados (SP) de T. lepturus da costa de São Paulo, e seus respectivos diagramas de dispersão de resíduos. 

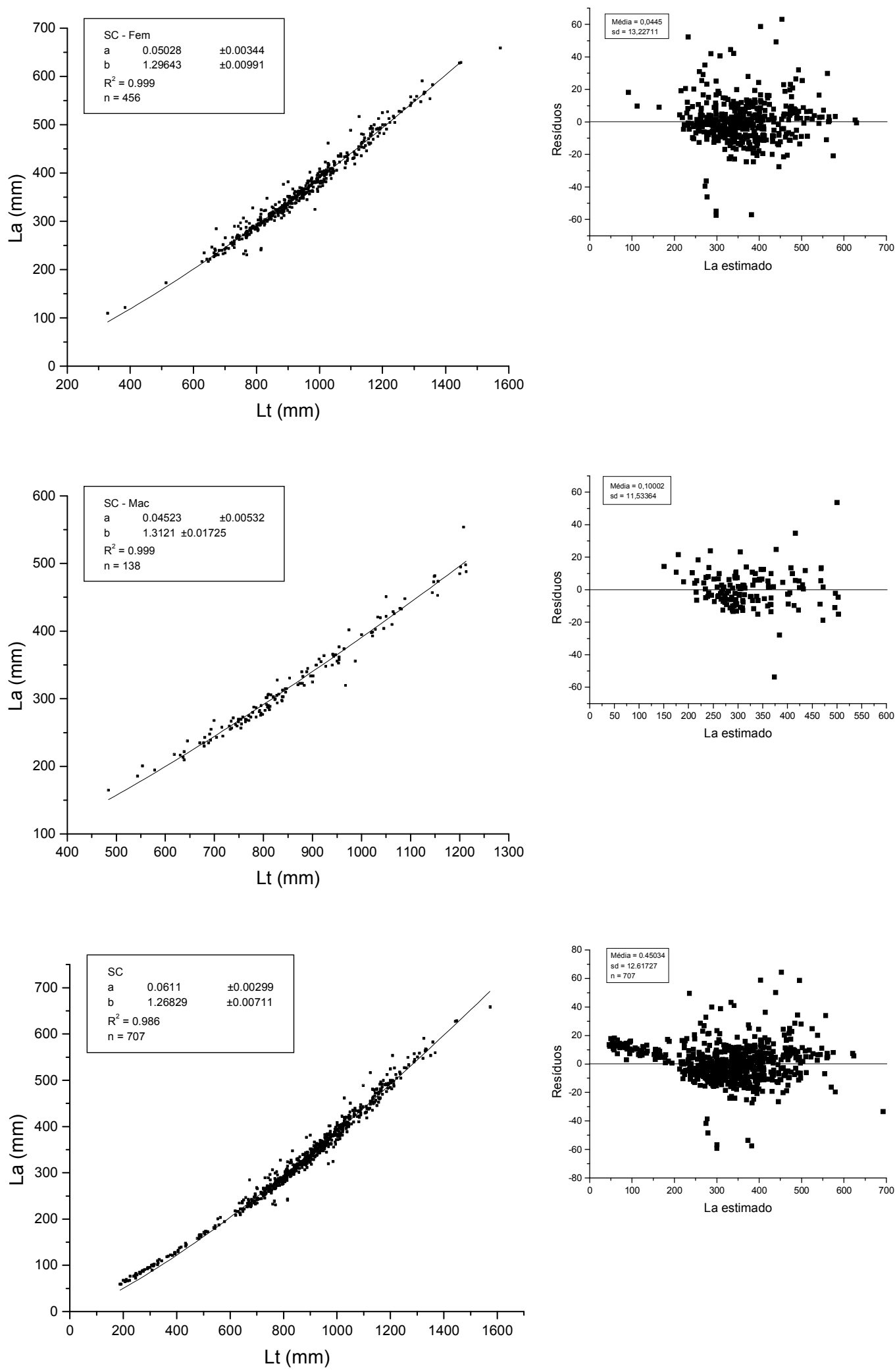

Figura 57: Relações entre o comprimento anal e comprimento total dos exemplares fêmeas (SC -Fem), machos (SC - Mac) e sexos agrupados (SC) de T. lepturus de Porto Belo (SC), e seus respectivos diagramas de dispersão de resíduos. 

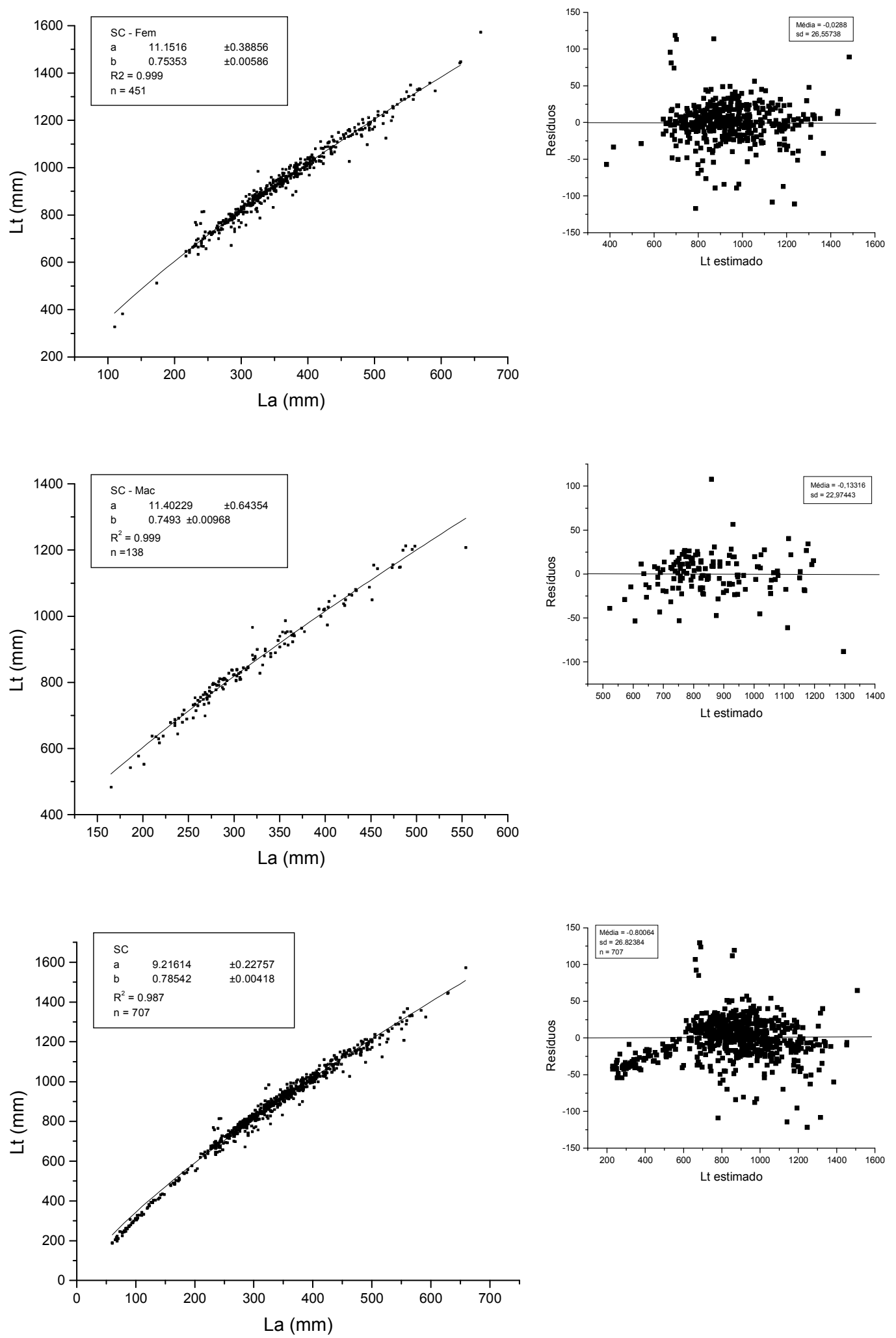

Figura 58: Relações entre o comprimento total e comprimento anal dos exemplares fêmeas (SC -Fem), machos (SC - Mac) e sexos agrupados (SC) de T. lepturus de Porto Belo (SC), e seus respectivos diagramas de dispersão de resíduos. 

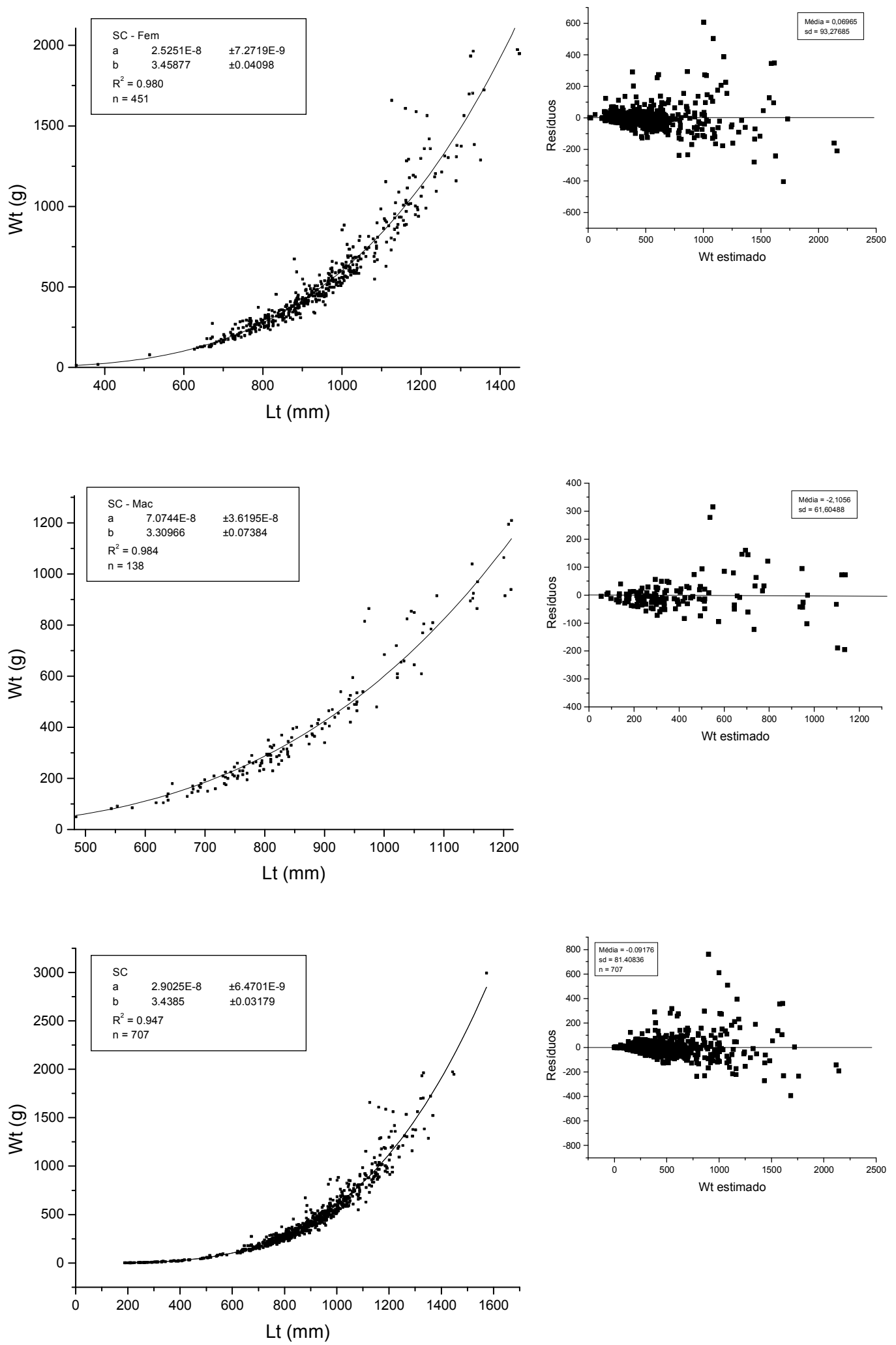

Figura 59: Relações entre o peso total e comprimento total dos exemplares fêmeas (SC -Fem), machos (SC - Mac) e sexos agrupados (SC) de T. lepturus de Porto Belo (SC), e seus respectivos diagramas de dispersão de resíduos. 

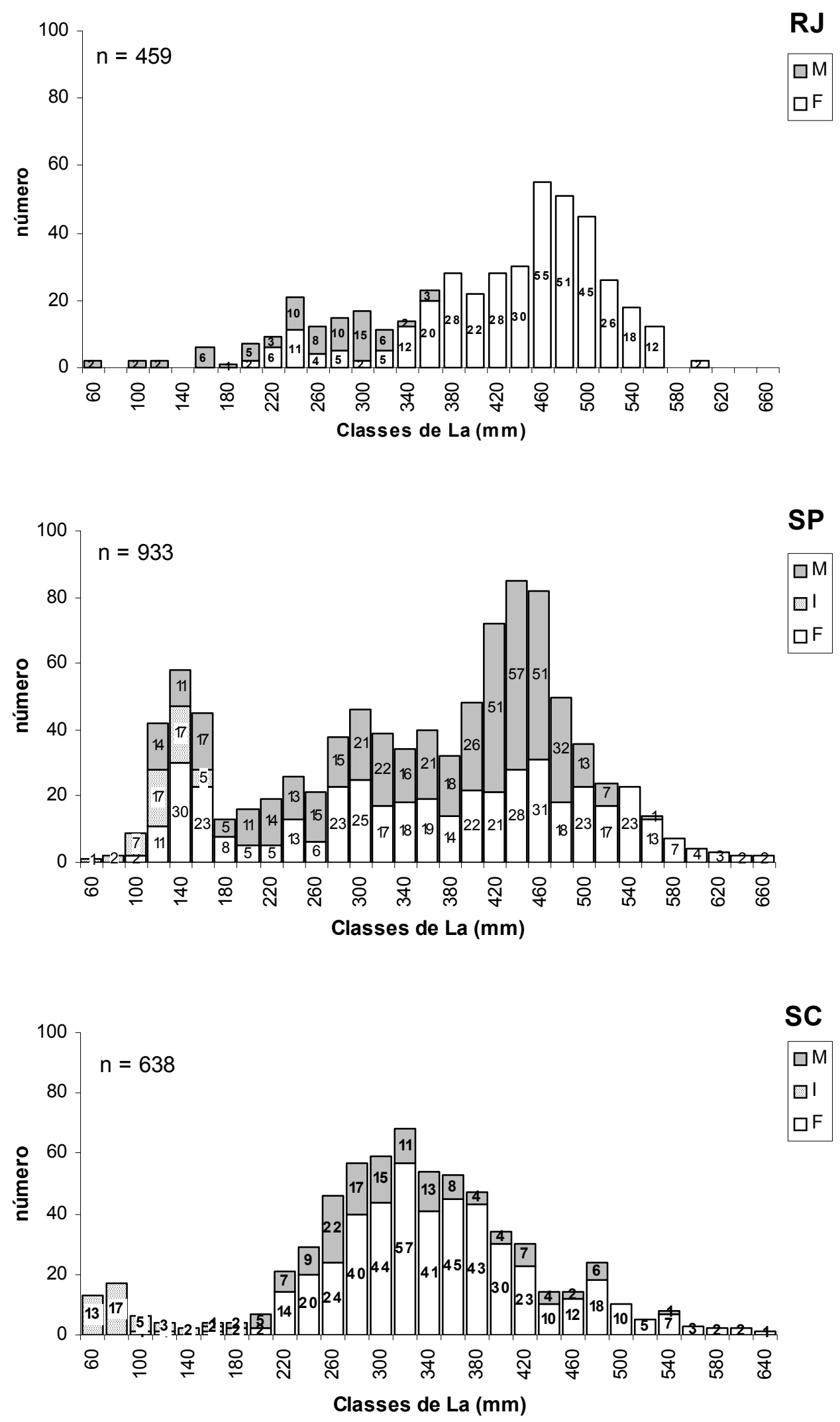

Figura 60: Freqüência absoluta dos exemplares de T. lepturus, por classe de comprimento anal e sexo, capturados nos diversos Estados. 
RJ - Fêmeas

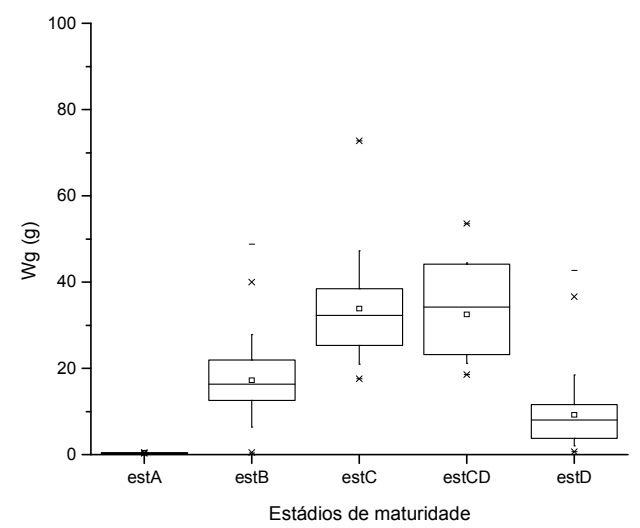

SP - Fêmeas

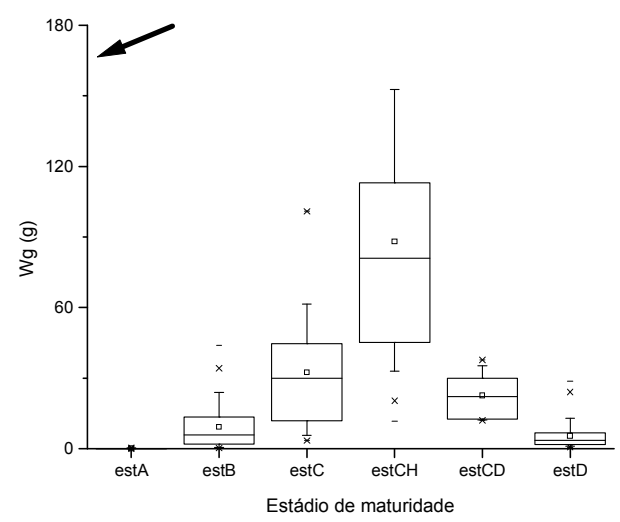

SC - Fêmeas

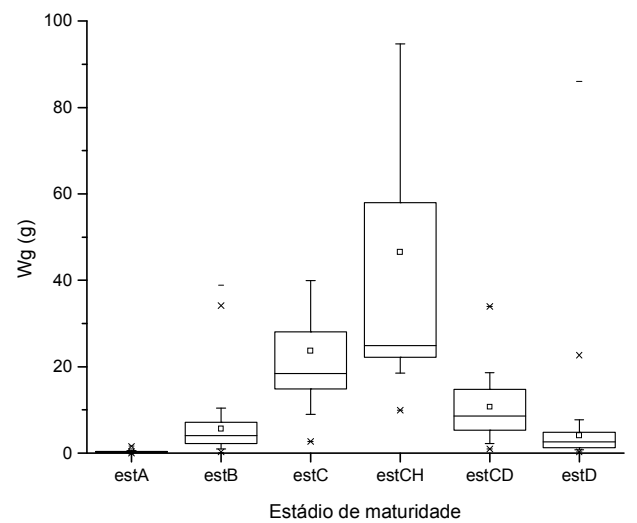

RJ - Machos

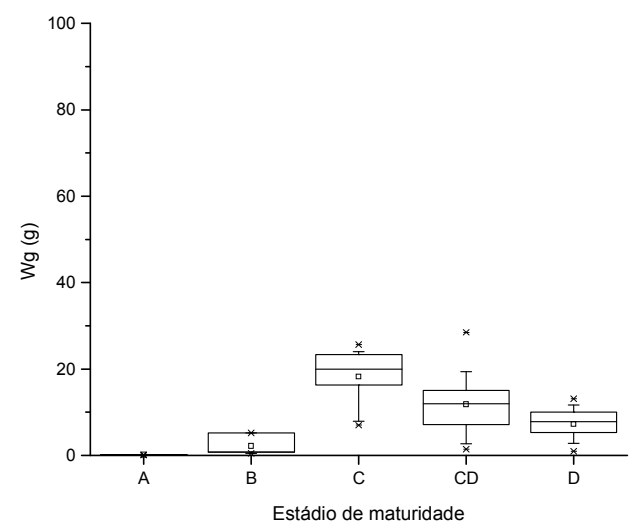

SP - Machos

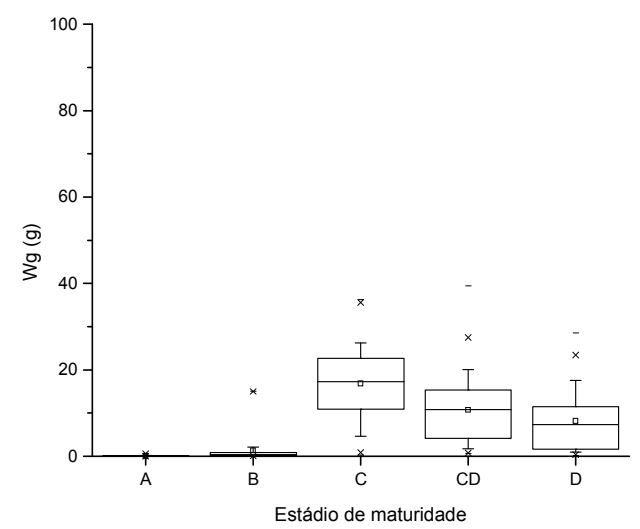

SC - Machos

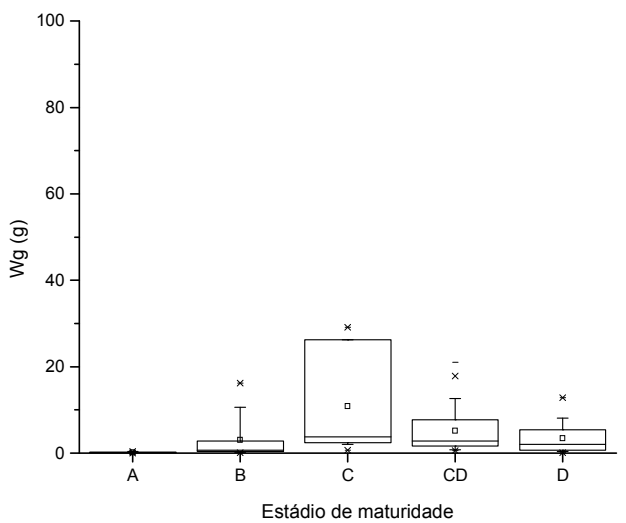

Figura 61: Boxplot do peso das gônadas por sexo e estádio de maturidade dos exemplares de T. lepturus capturados em cada Estado. A seta indica escala diferenciada dos demais. 

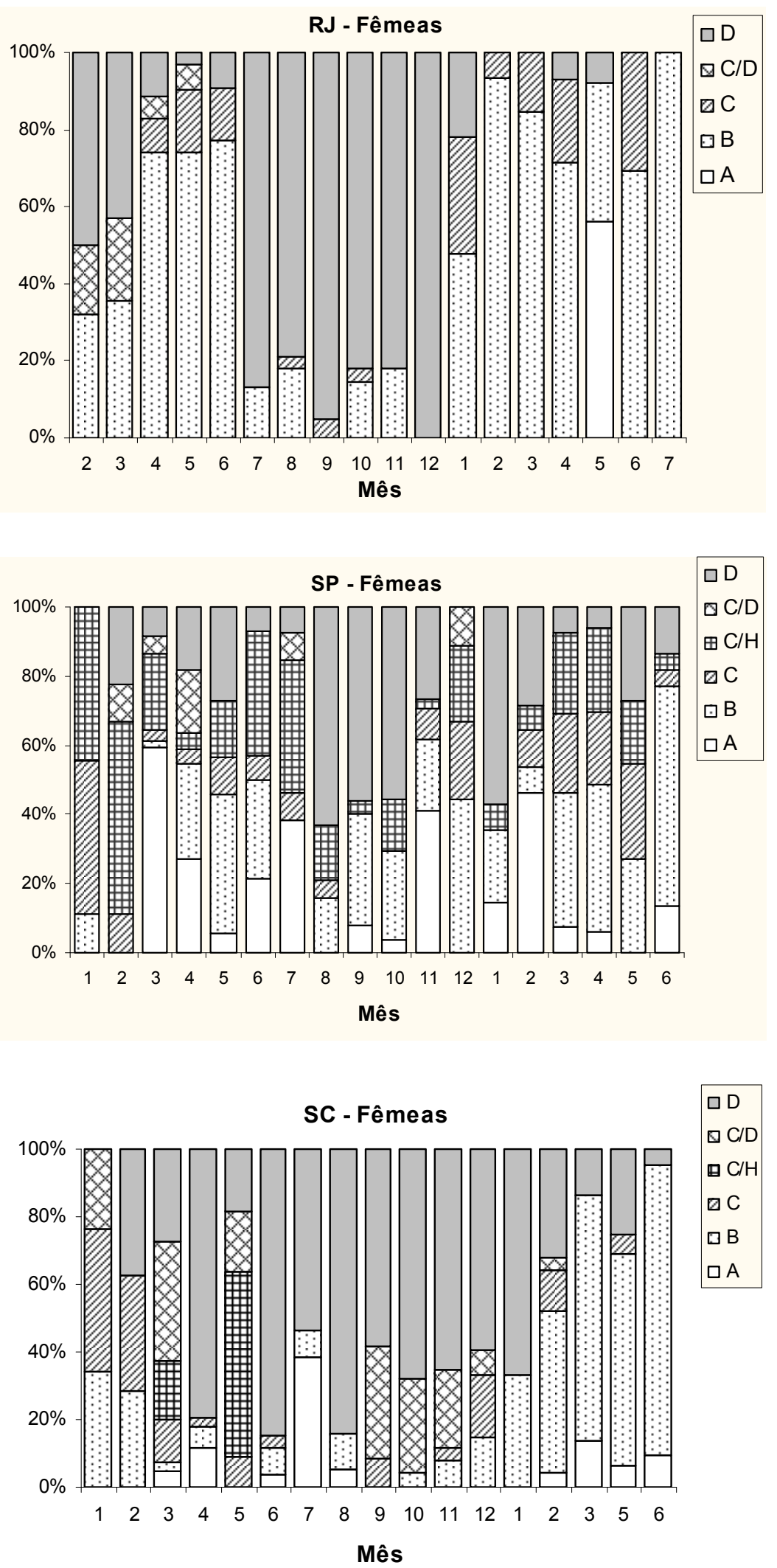

Figura 62: Freqüência relativa mensal de estádios de maturidade de fêmeas de T. lepturus coletados nos diferentes Estados. 

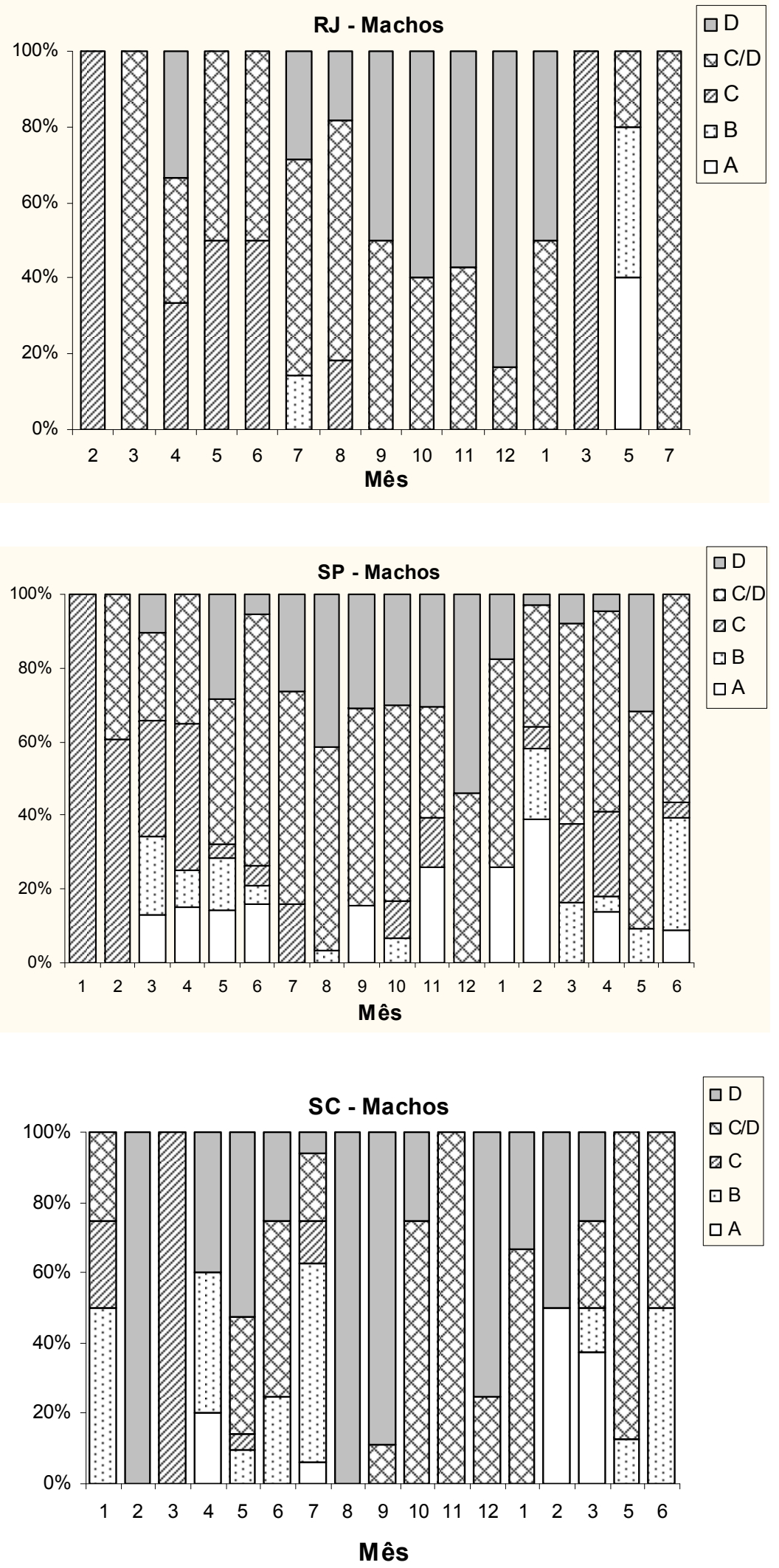

Figura 63: Freqüência relativa mensal de estádios de maturidade de machos de T. lepturus coletados nos diferentes Estados 

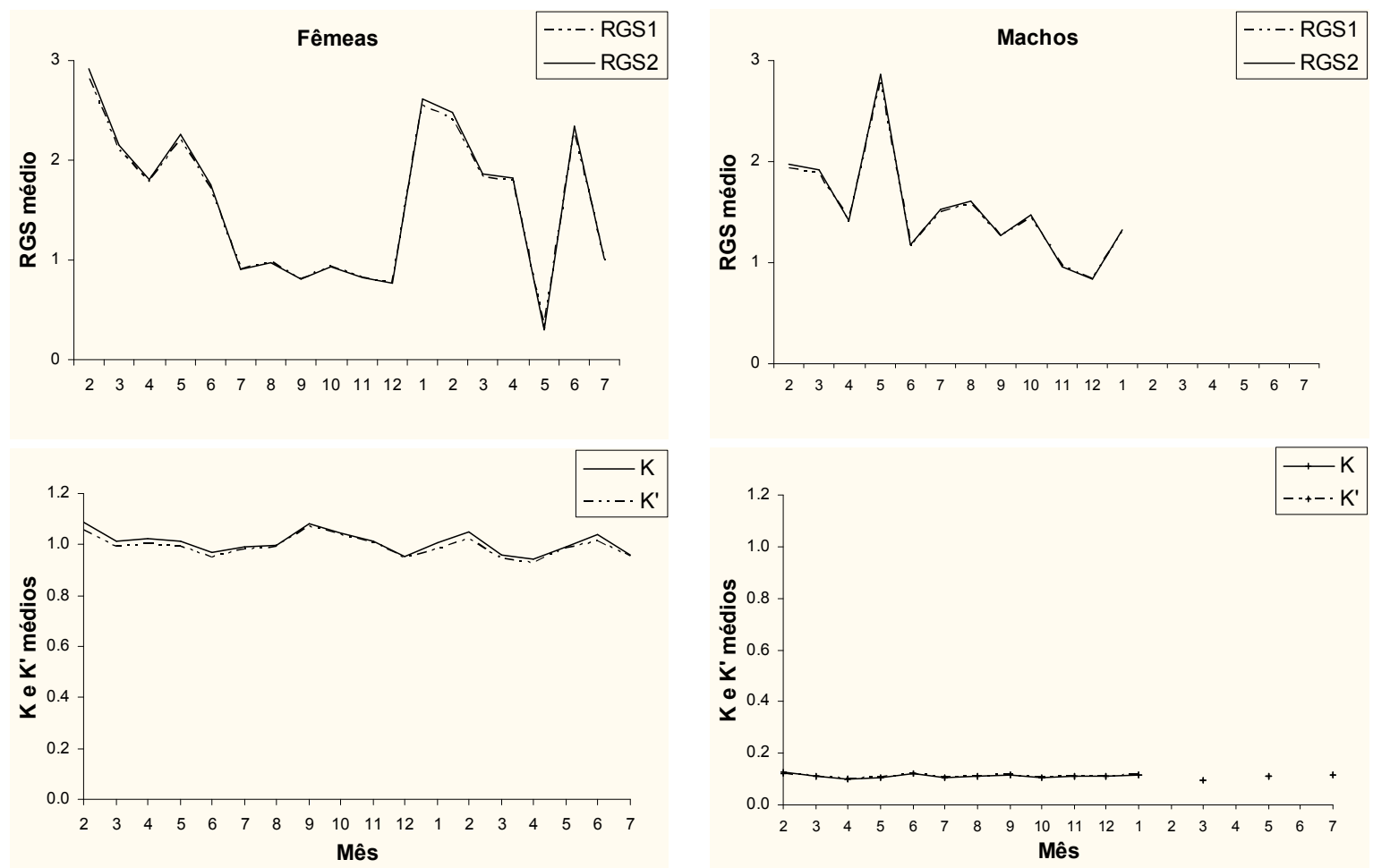

Figura 64: Variação mensal das relações gonadossomáticas médias (RGS1 e RGS2) e fatores de condição alométrico médios (K e K') de fêmeas e machos de T. lepturus coletados em Arraial do Cabo $(\mathrm{RJ})$.

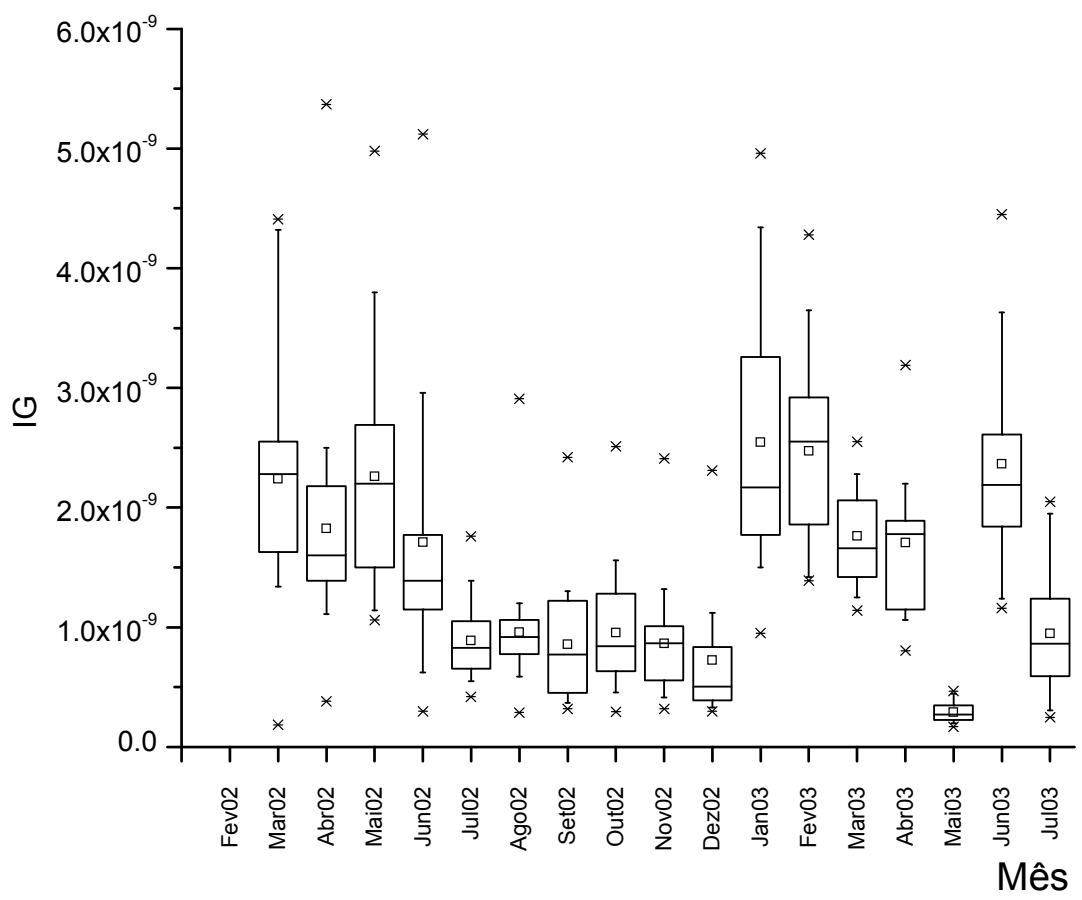

Figura 65: Boxplot dos índices gonadais (IG) mensais das fêmeas de T. lepturus coletadas na região de Arraial do Cabo (RJ). 

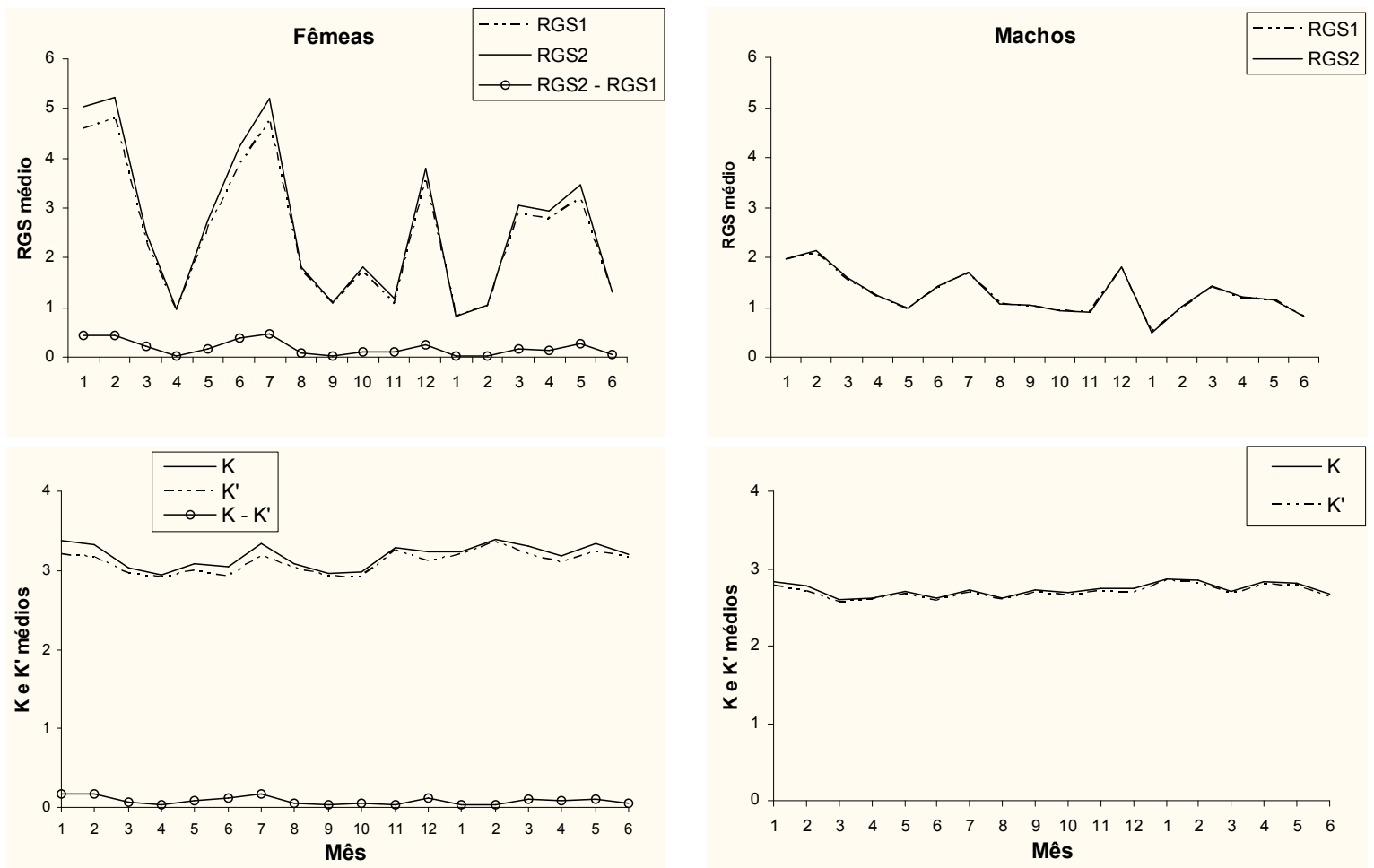

Figura 66: Variação mensal das relações gonadossomáticas médias (RGS1 e RGS2) e fatores de condição alométrico médios (K e K') de fêmeas e machos de T. lepturus coletados no Guarujá (SP), e suas respectivas diferenças em fêmeas.

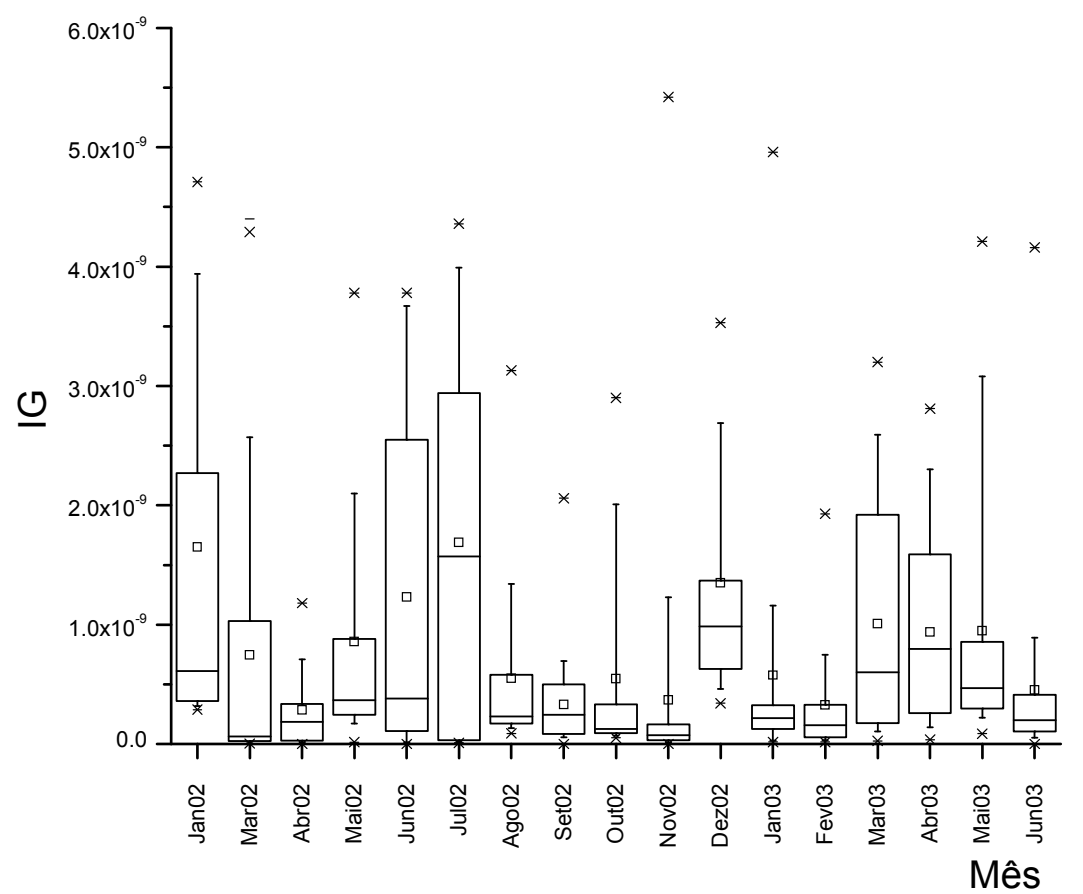

Figura 67: Boxplot dos índices gonadais (IG) mensais das fêmeas de T. lepturus coletadas em São Paulo. 

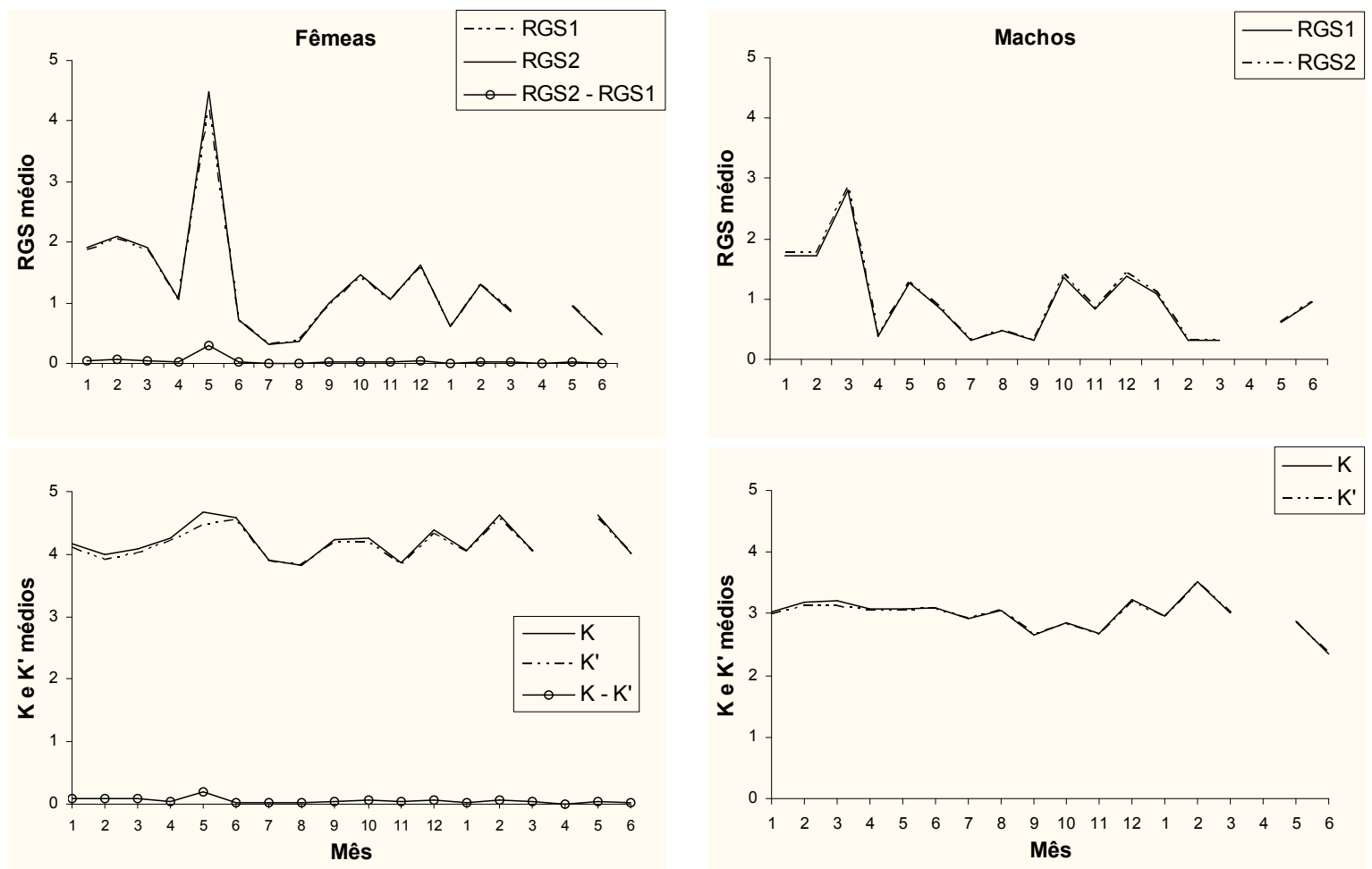

Figura 68: Variação mensal das relações gonadossomáticas médias (RGS1 e RGS2) e fatores de condição alométrico médios (K e K') de fêmeas e machos de T. lepturus coletados em Porto Belo (SC), e as suas respectivas diferenças em fêmeas.

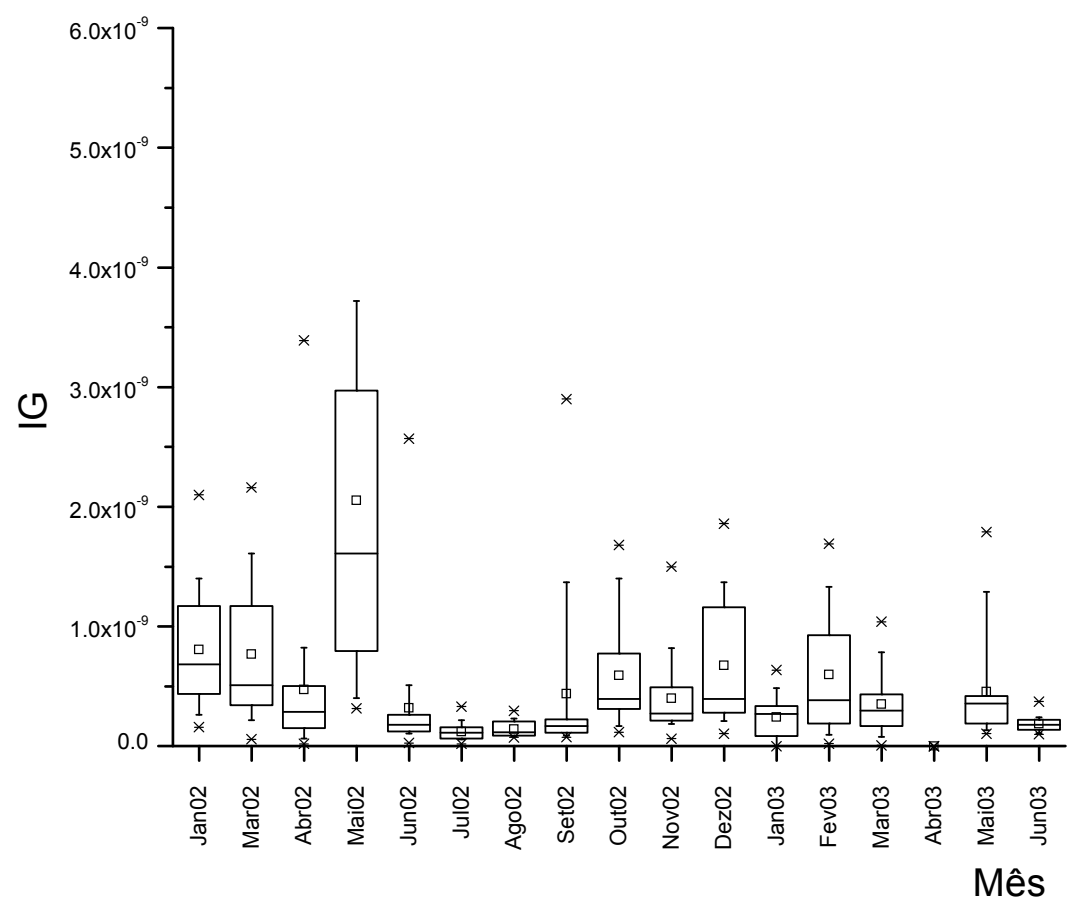

Figura 69: Boxplot dos índices gonadais (IG) mensais das fêmeas de T. lepturus coletadas na região de Porto Belo (SC). 


\section{Fêmeas}

Rio de Janeiro

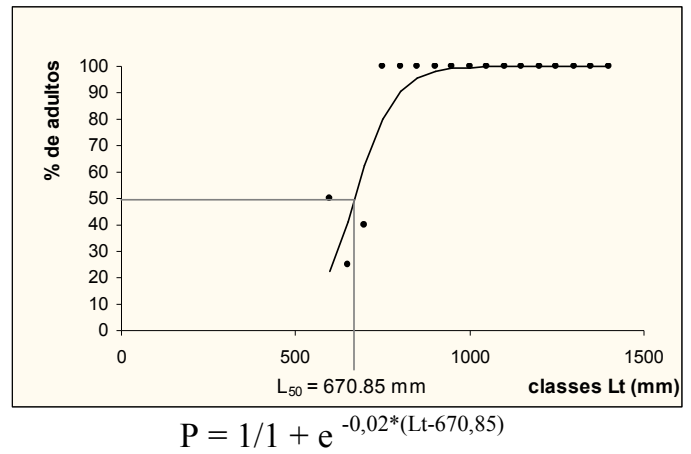

São Paulo

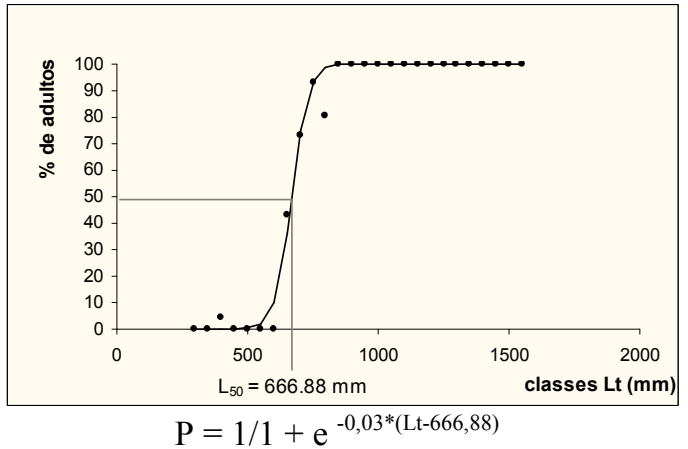

Santa Catarina

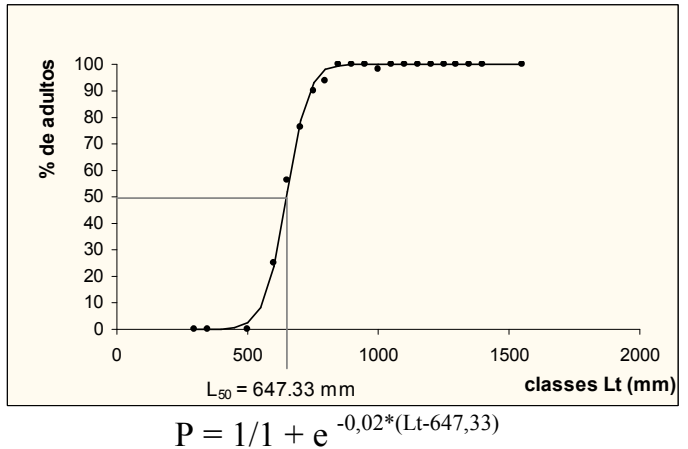

Machos
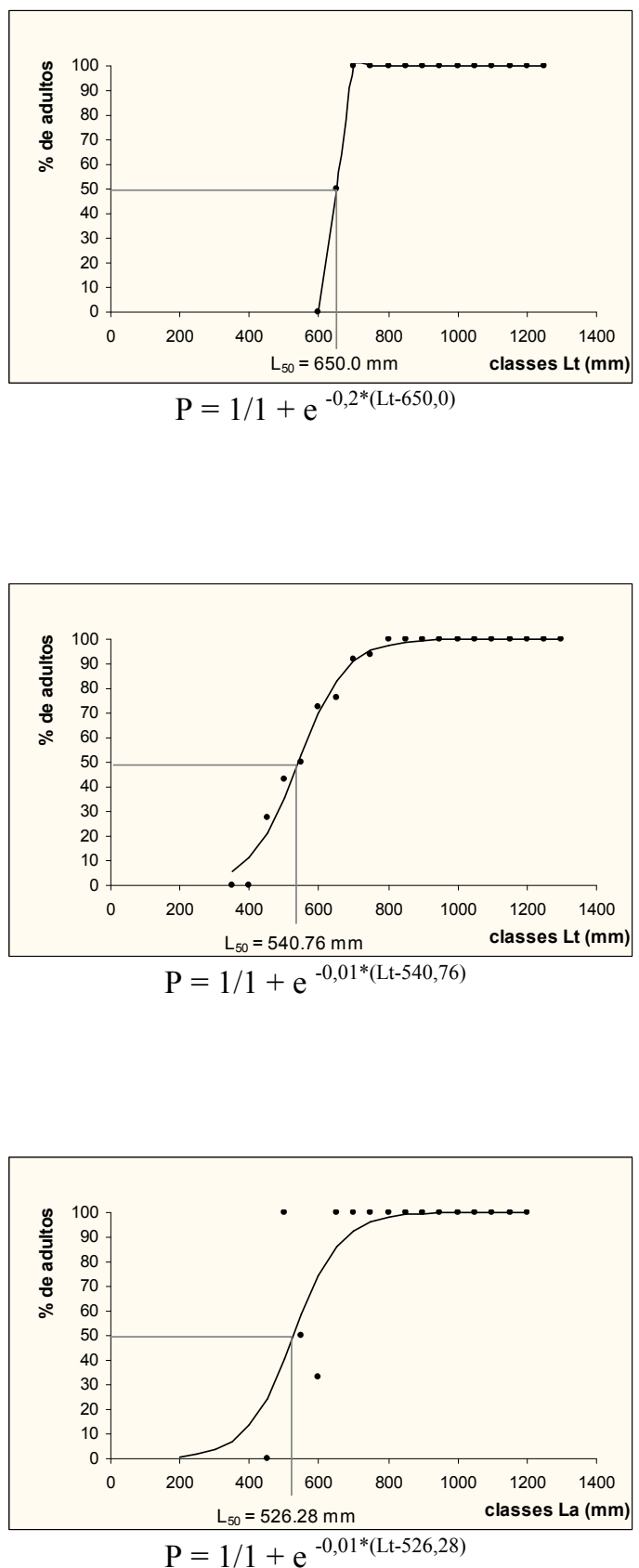

Figura 70: Curva de freqüência relativa acumulada de fêmeas e machos adultos por classe de comprimento total (mm) de T. lepturus coletados nos diferentes Estados 

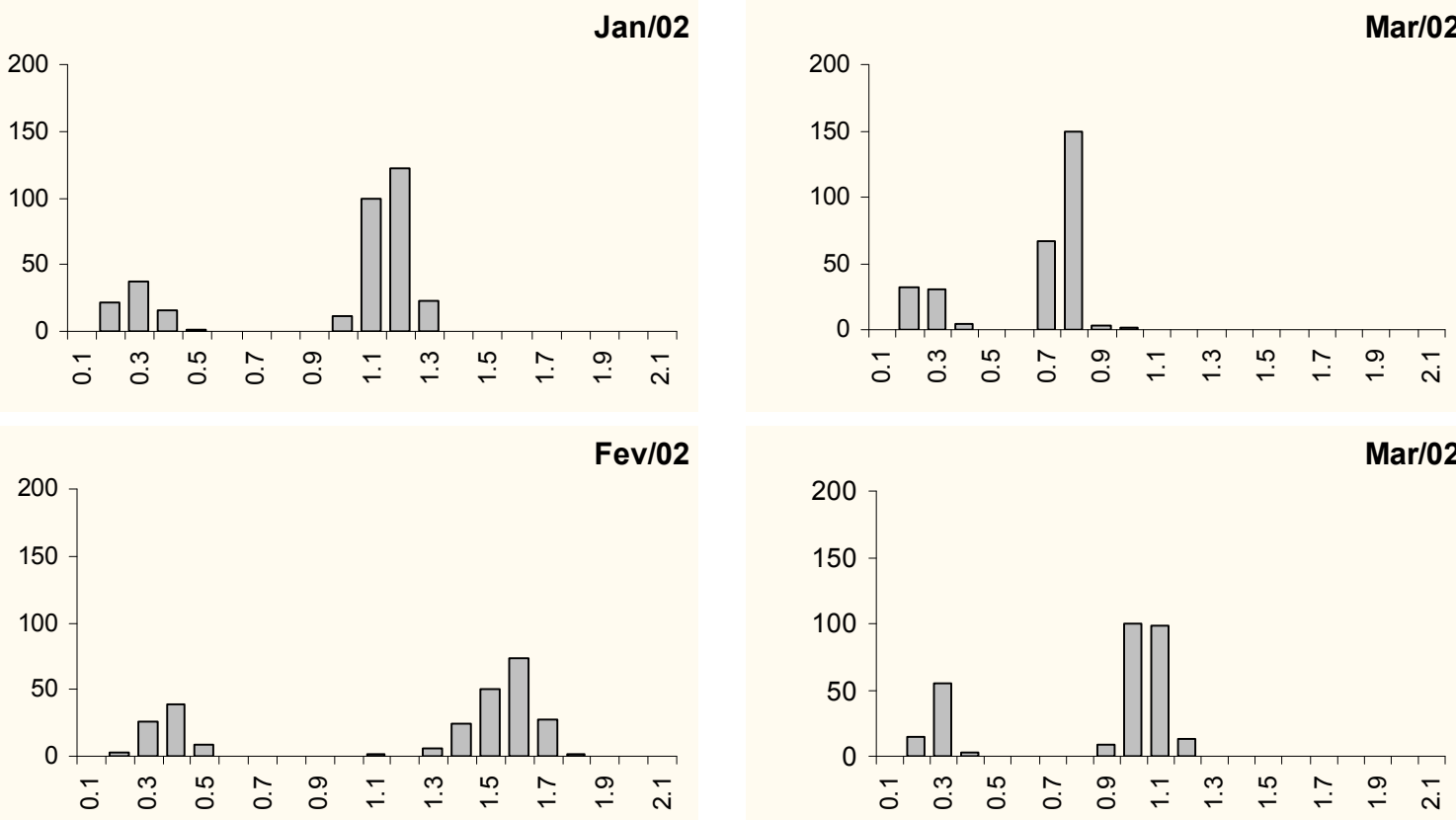

$\mathrm{Jul} / 02$

Mai/02
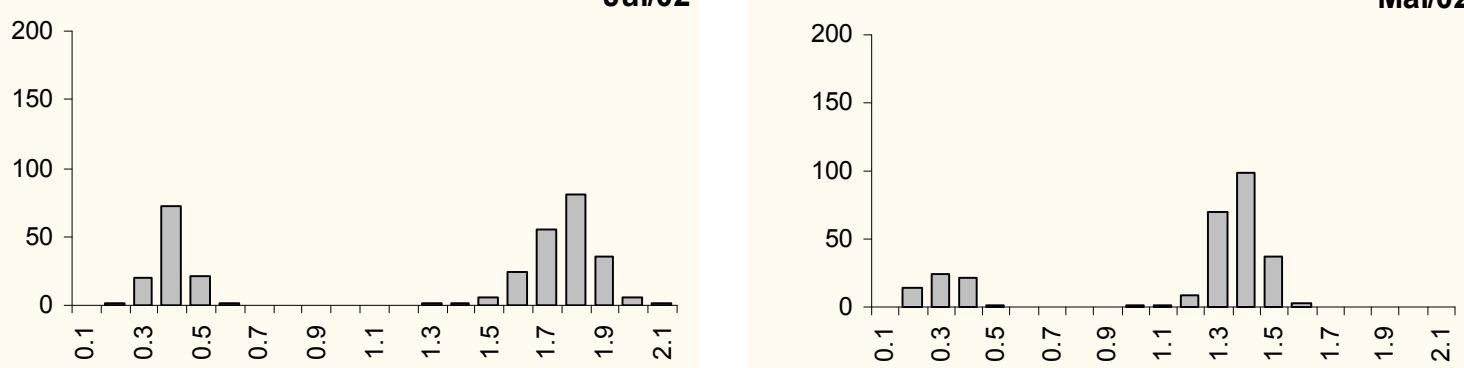

Diâmetro dos ovócitos (mm)

Figura 71: Distribuição de freqüência absoluta de diâmetros de ovócitos das gônadas de fêmeas maduras $(\mathrm{C}$ e $\mathrm{C} / \mathrm{H})$ de T. lepturus, coletados em diferentes amostras de São Paulo e Santa Catarina. 

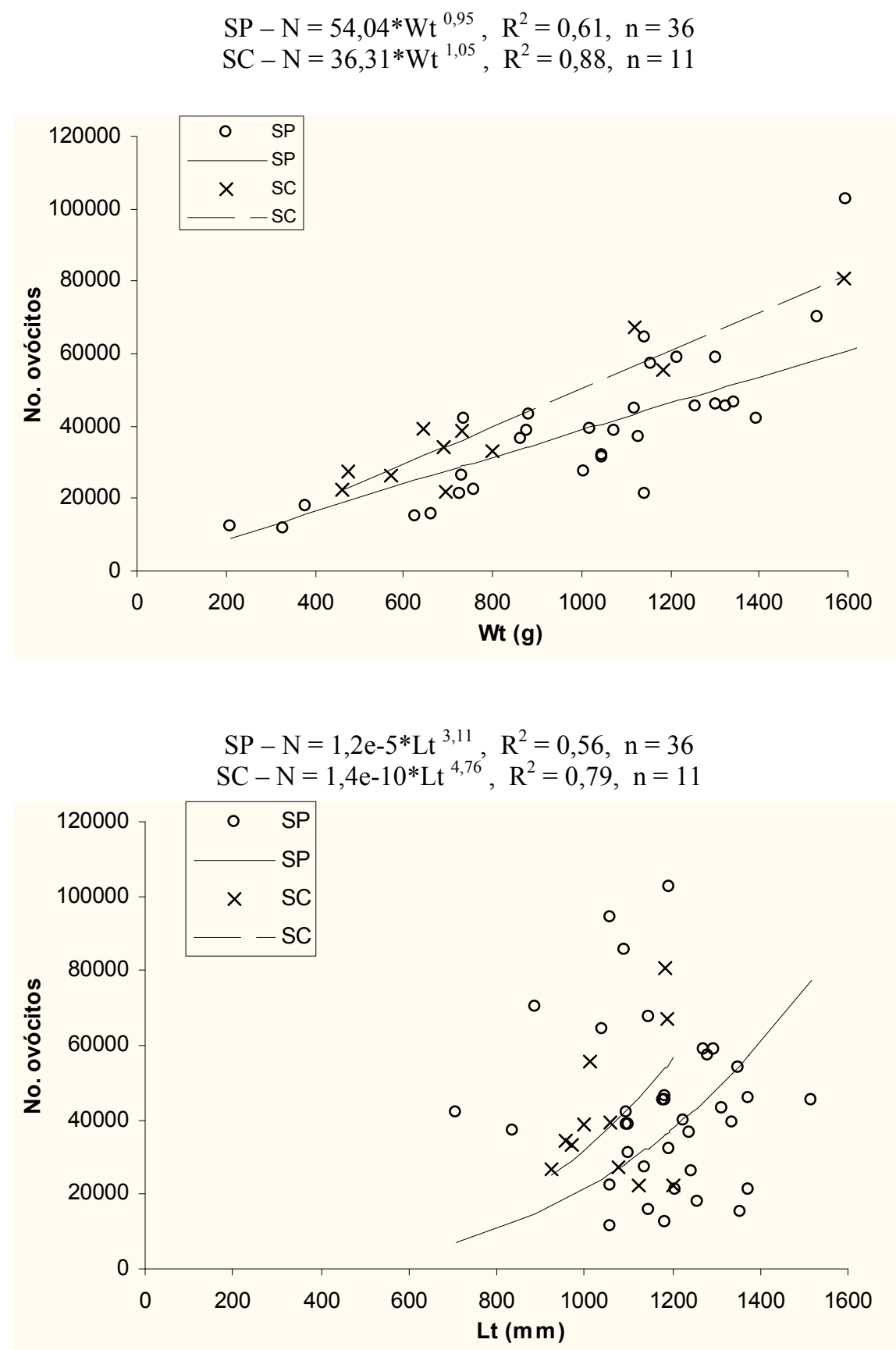

Figura 72: Relações entre fecundidade (em número de ovócitos) e comprimento total ( $\mathrm{Lt}-\mathrm{mm}$ ) e peso total $(\mathrm{Wt}-\mathrm{g})$ das fêmeas maduras de T. lepturus coletados em São Paulo e Santa Catarina. 


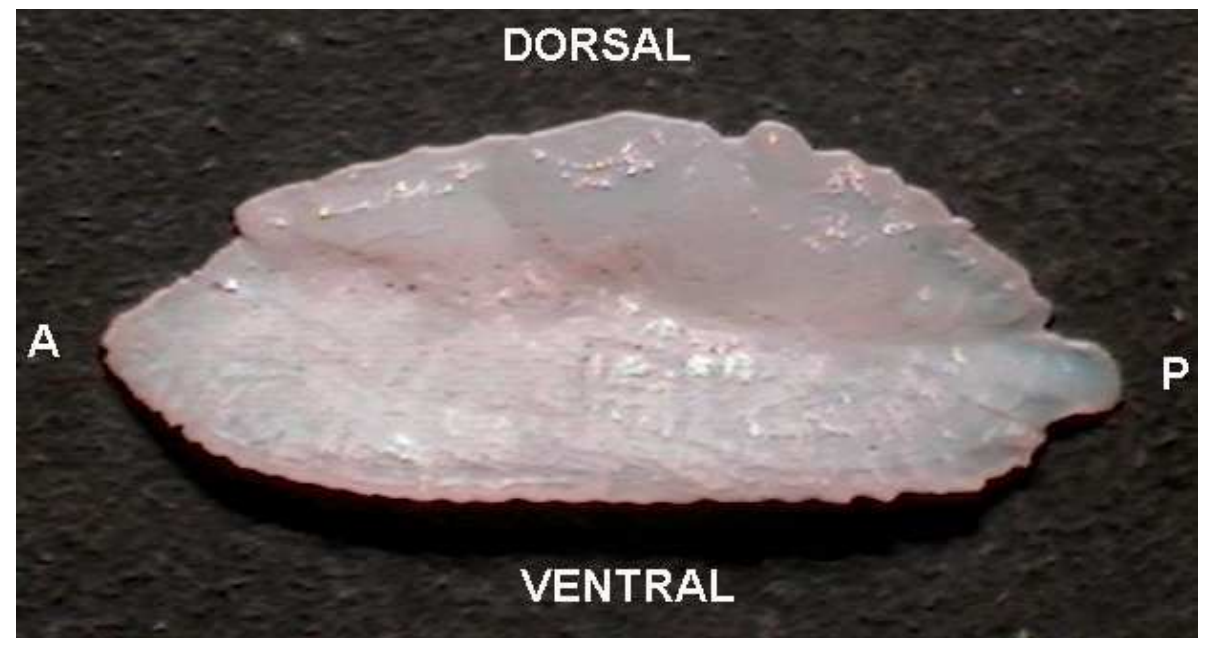

Figura 73: Otólito sagitta de T. lepturus: fêmea com 1230mm de comprimento total. Comprimento do otólito $7,8 \mathrm{~mm}$.

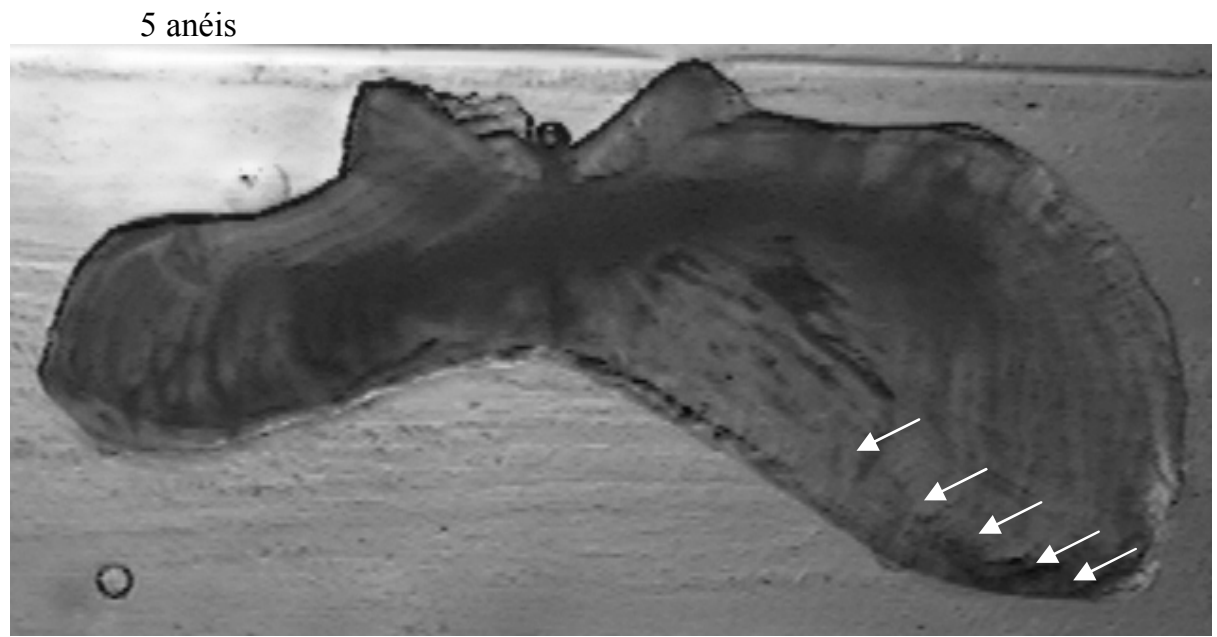

1 anel

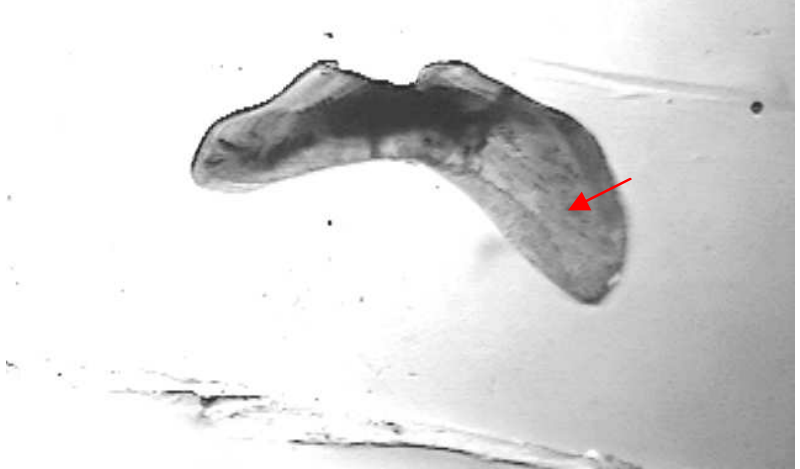

Figura 74: Cortes transversais de otólitos de T. lepturus com indicação dos anéis de crescimento 


\section{Rio de Janeiro}

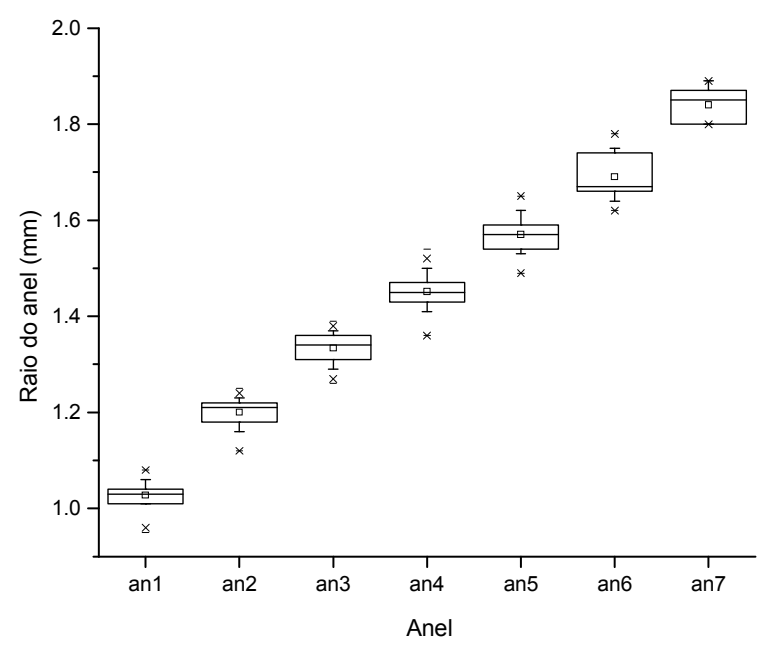

\section{São Paulo}

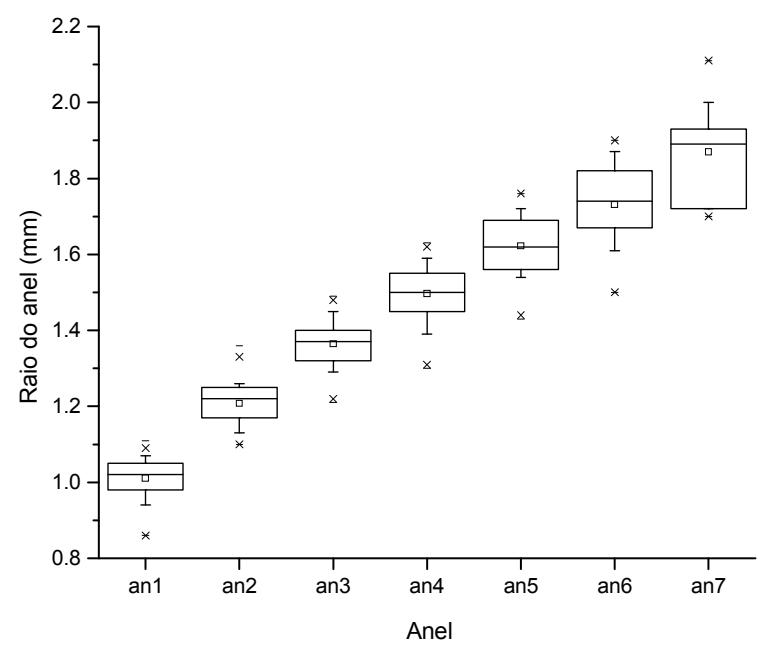

\section{Santa Catarina}

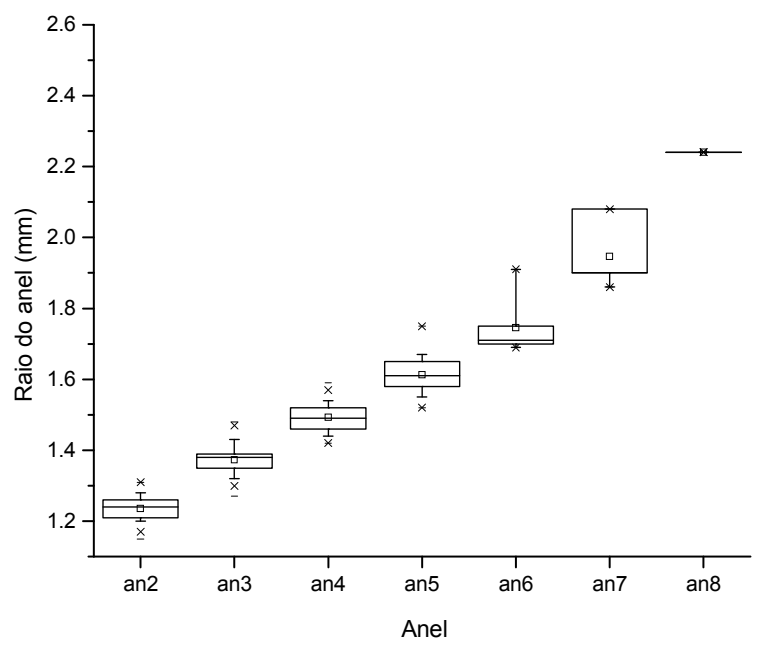

Figura 75: Boxplot dos raios de cada anel observado nos otólitos de T. lepturus coletados nos diferentes Estados analisados. 


\section{Rio de Janeiro}

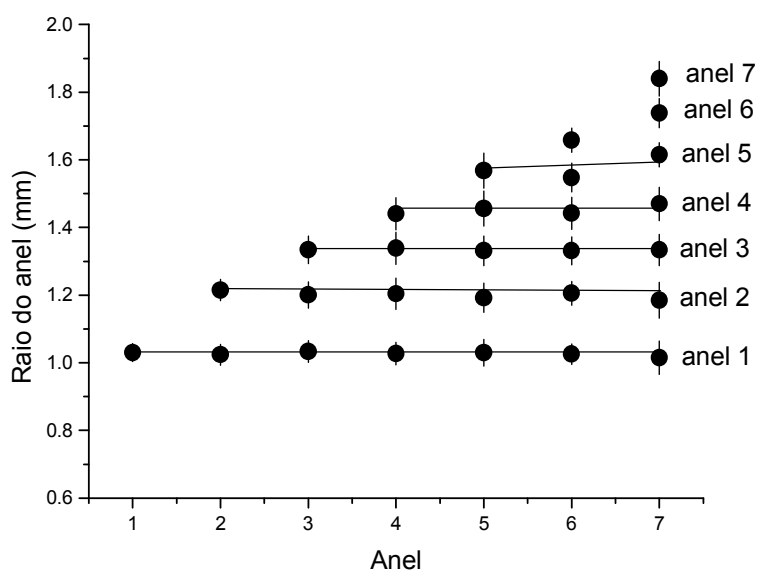

\section{São Paulo}

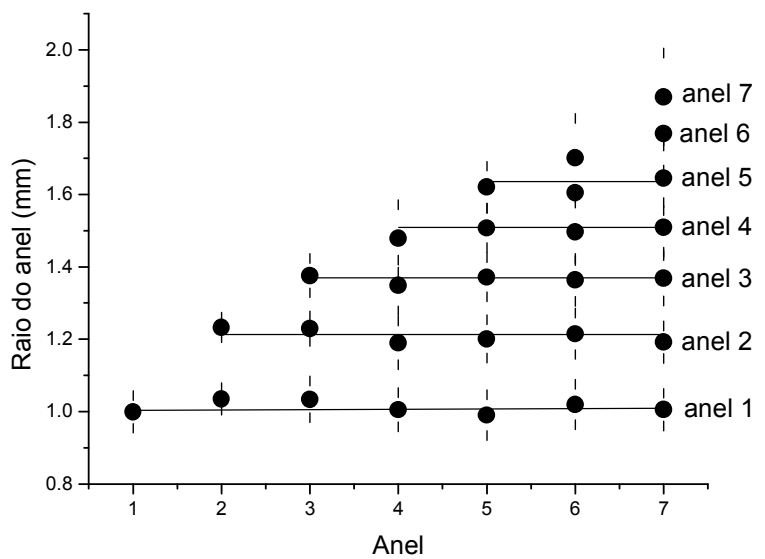

\section{Santa Catarina}

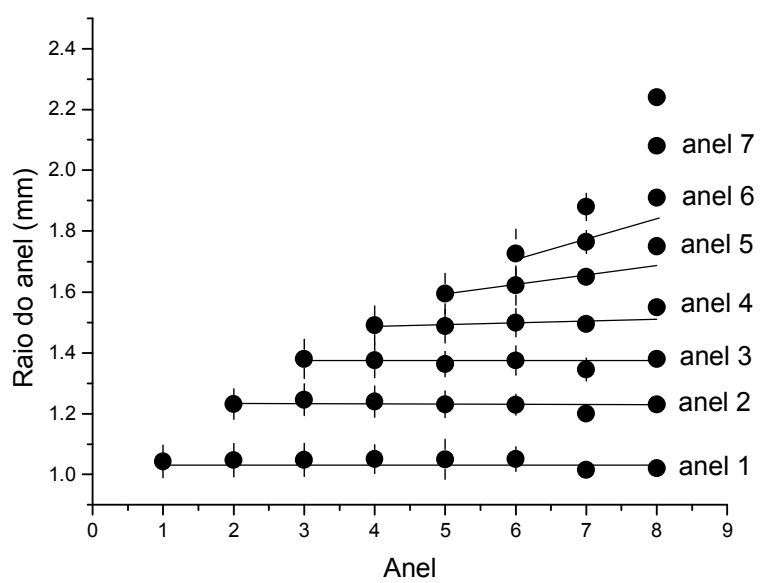

Figura 76: Constância na formação dos anéis dos otólitos de indivíduos de diferentes idades de T. lepturus em cada Estado analisado. 


\section{Rio de Janeiro}

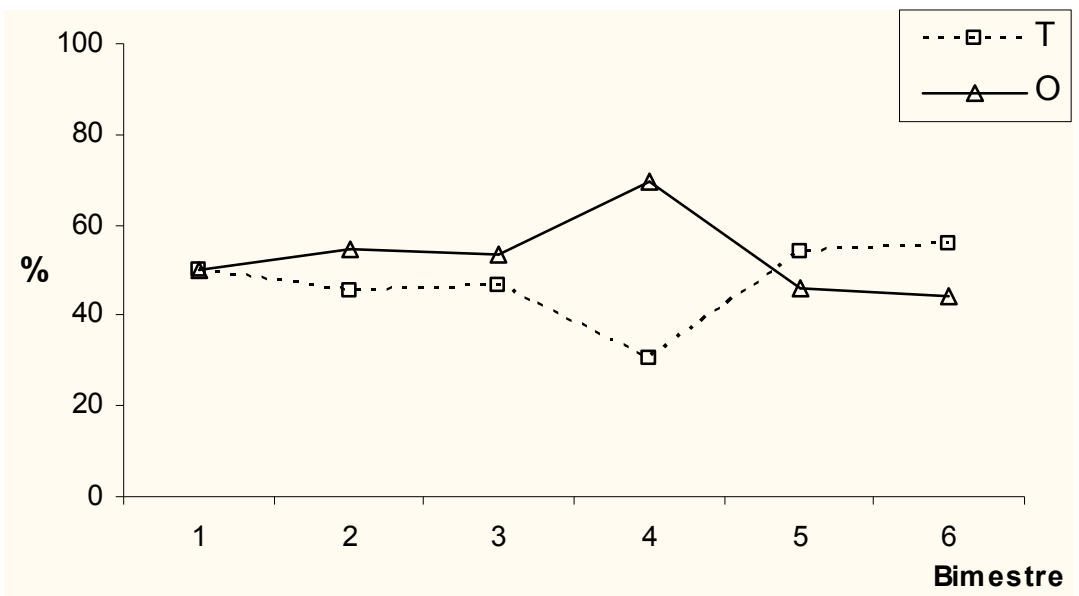

\section{São Paulo}

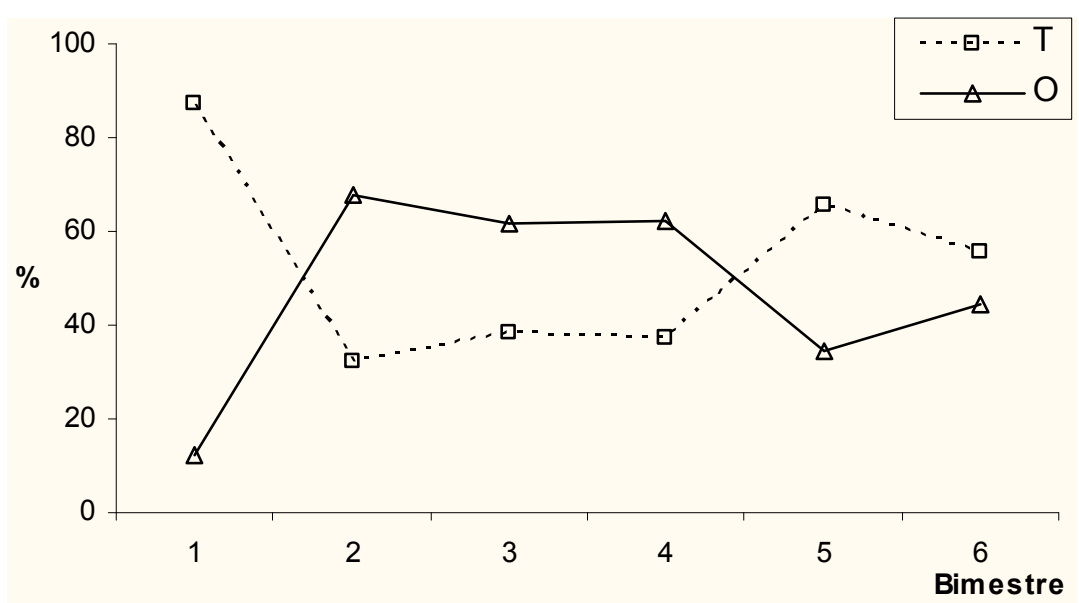

\section{Santa Catarina}

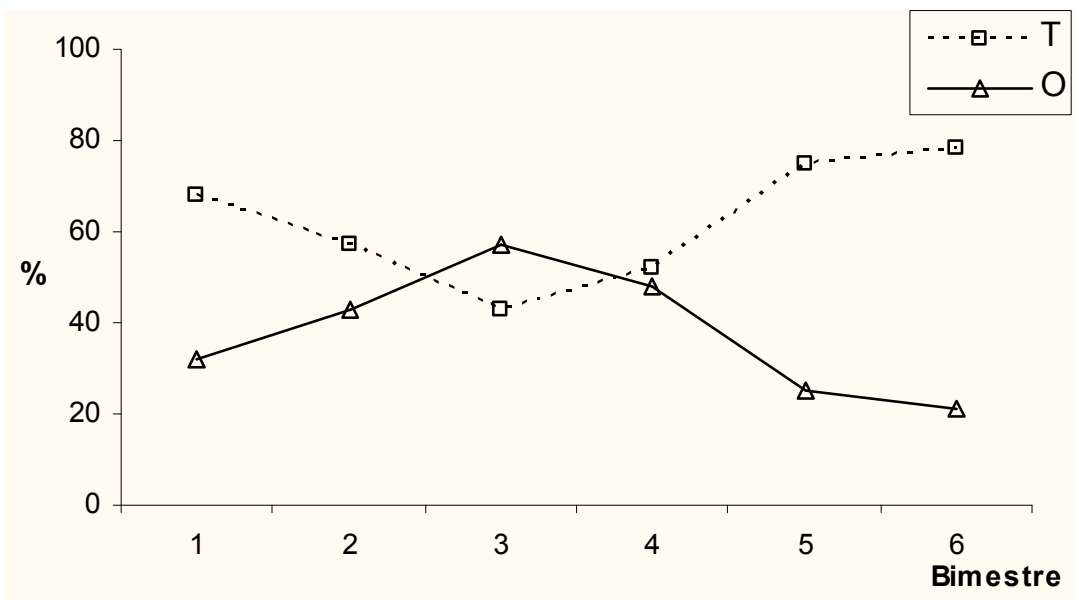

Figura 77: Proporção bimestral de borda opaca $(\mathrm{O})$ e translúcida $(\mathrm{T})$ nos otólitos dos exemplares de $T$. lepturus coletados em cada Estado. 


\section{Rio de Janeiro}

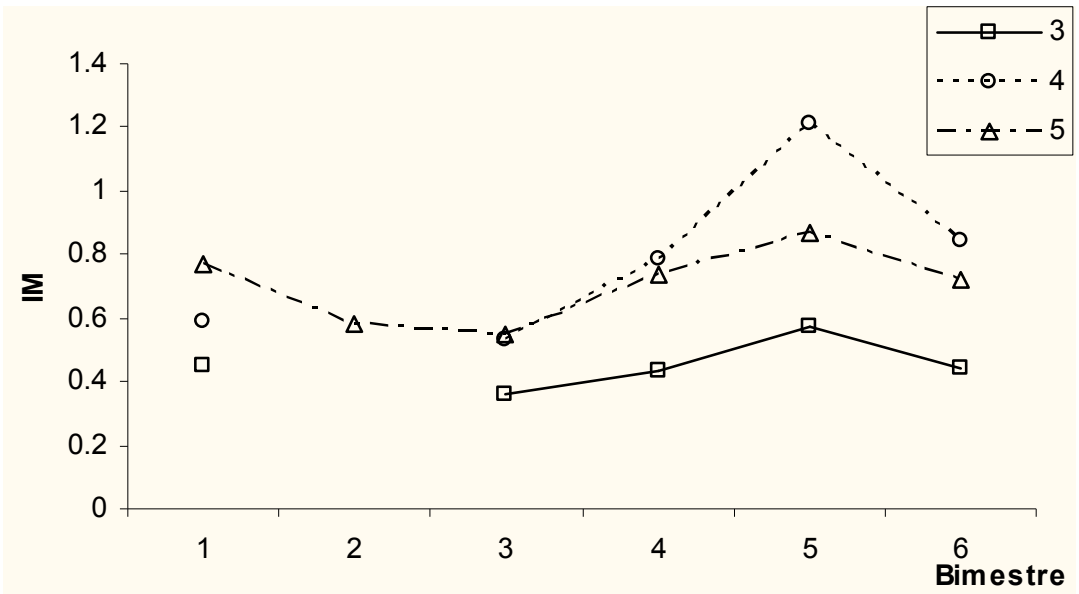

\section{São Paulo}

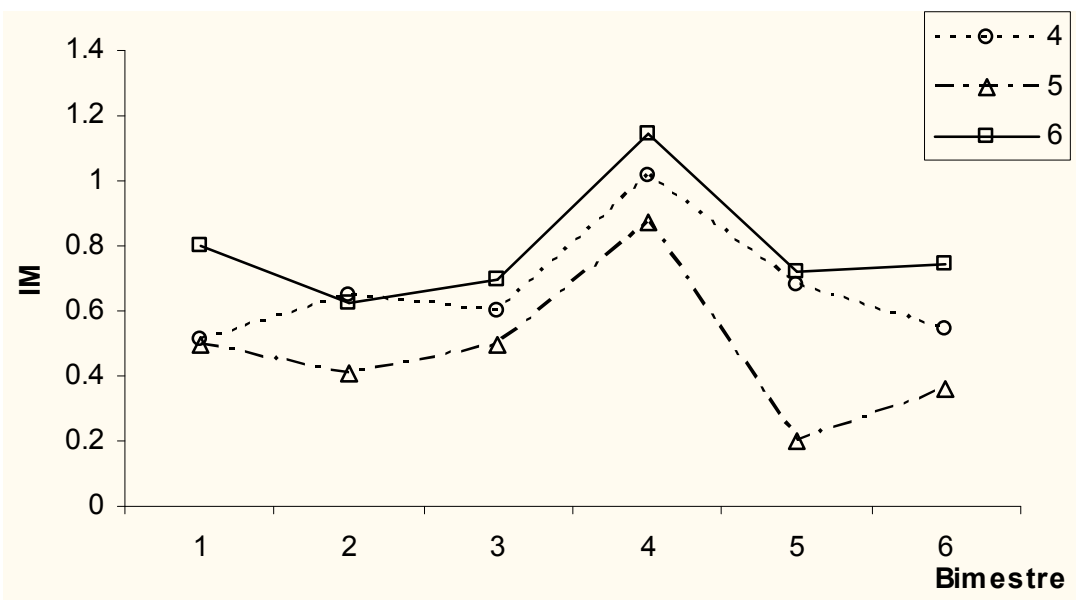

\section{Santa Catarina}

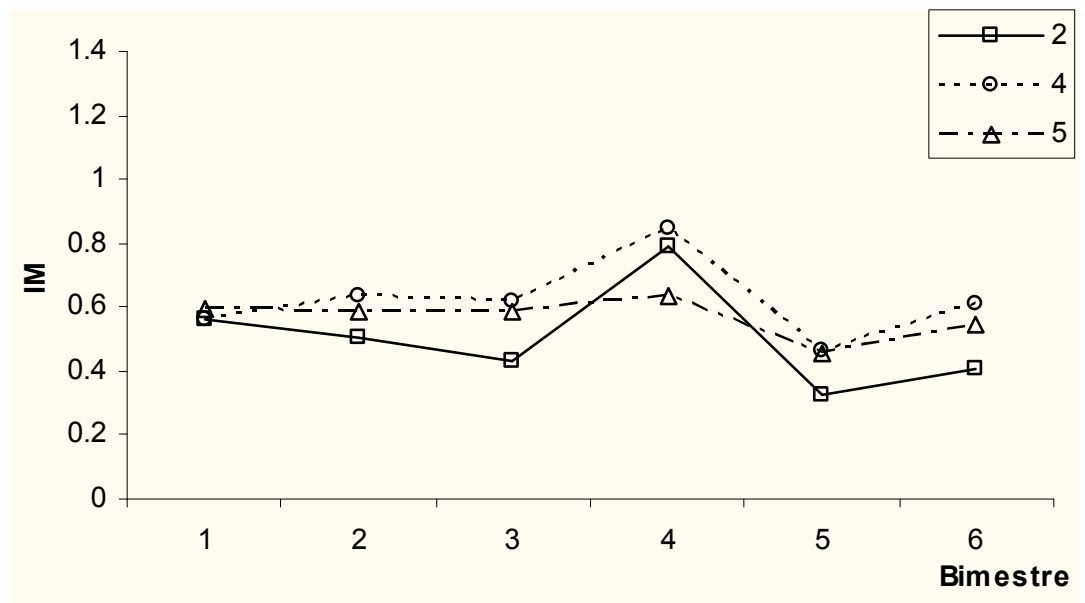

Figura 78: Variação bimestral do incremento marginal médio (IM) para exemplares de T. lepturus com 2, 4 e 5 anéis de crescimento nos otólitos. 

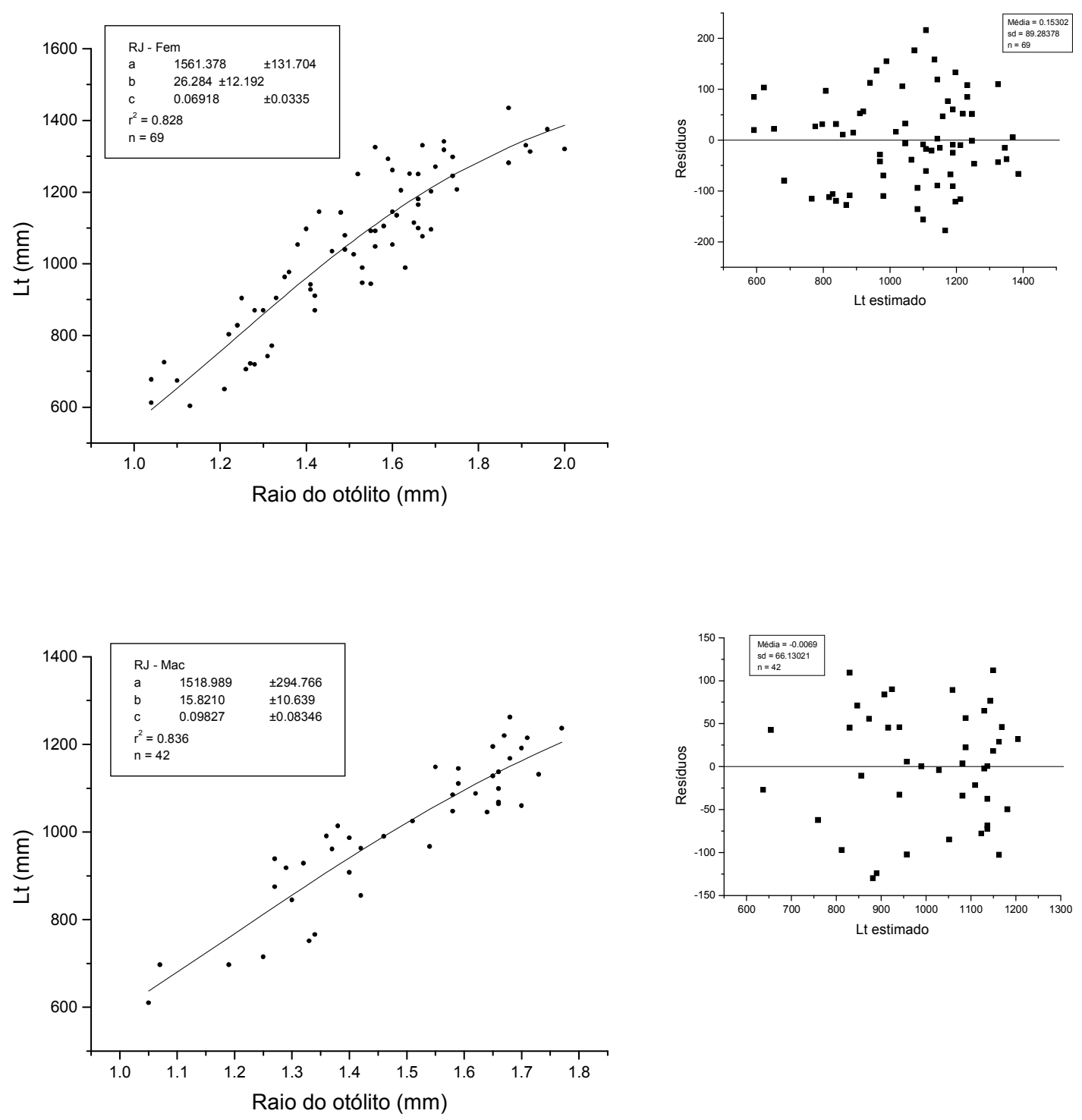

Figura 79: Curvas ajustadas pelo modelo logístico $\left(\mathrm{Lt}=\mathrm{a} / 1+\mathrm{b} * \mathrm{c}^{\mathrm{Rt}}\right)$ aos dados de comprimento total (Lt) e raio total dos otólitos (Rt) de T. lepturus da região de Arraial do Cabo (RJ) e respectivos diagramas de dispersão de resíduos. 

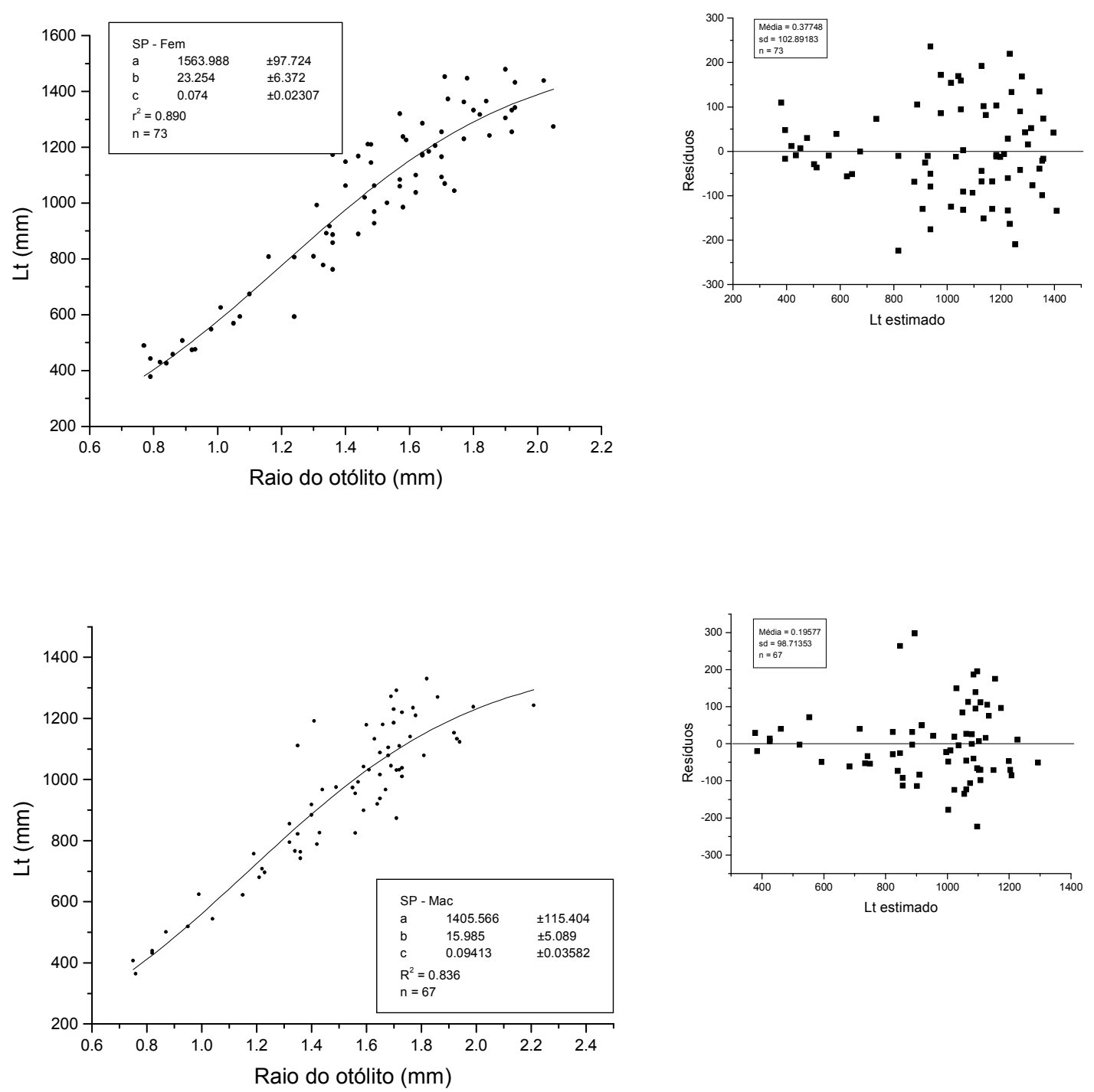

Figura 80: Curvas ajustadas pelo modelo logístico $\left(\mathrm{Lt}=\mathrm{a} / 1+\mathrm{b} * \mathrm{c}^{\mathrm{Rt}}\right)$ aos dados de comprimento total (Lt) e raio total dos otólitos (Rt) por sexo de T. lepturus da costa de São Paulo e respectivos diagramas de dispersão de resíduos. 

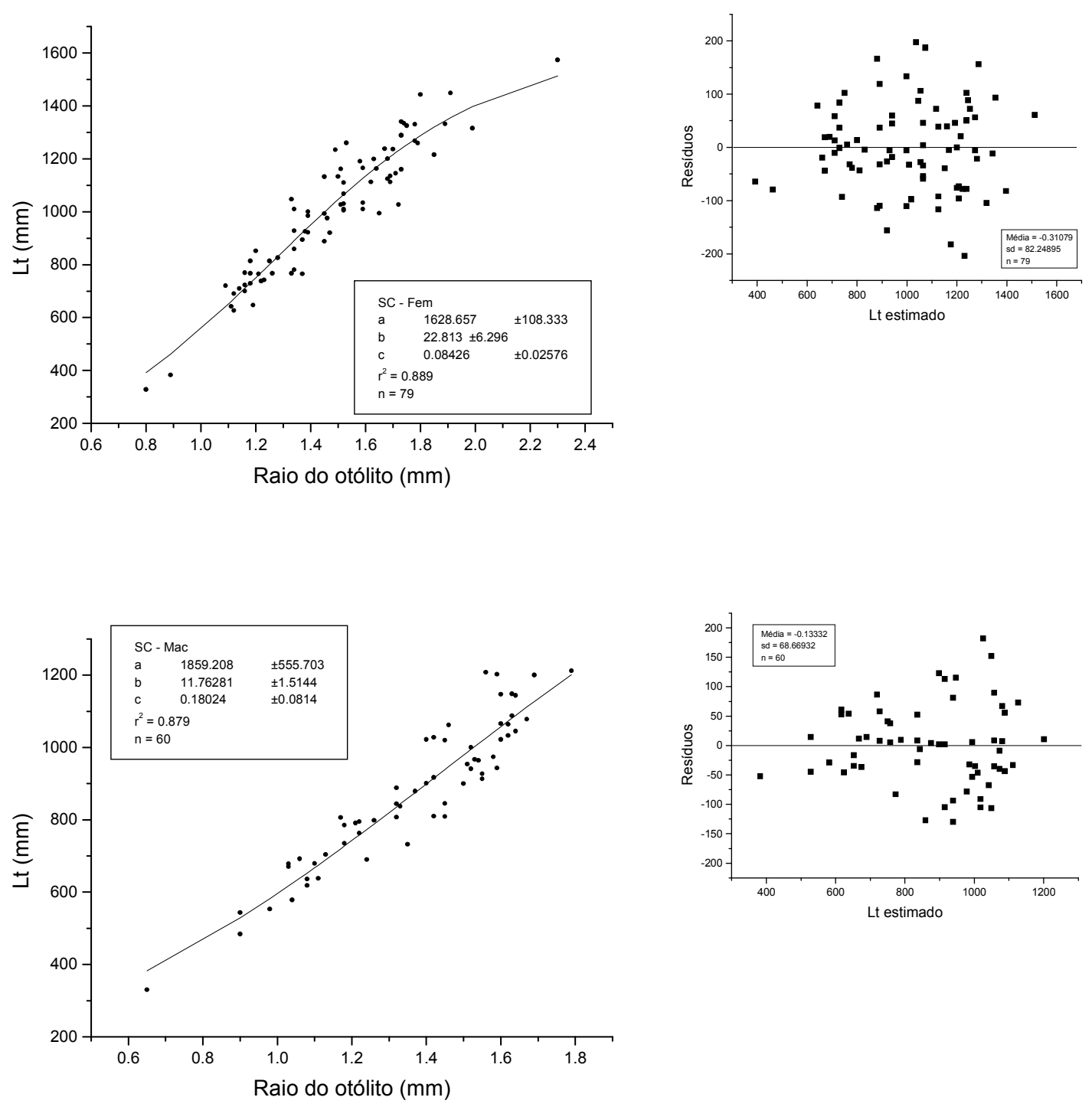

Figura 81: Curvas ajustadas pelo modelo logístico $\left(\mathrm{Lt}=\mathrm{a} / 1+\mathrm{b} * \mathrm{c}^{\mathrm{Rt}}\right)$ aos dados de comprimento total (Lt) e raio total dos otólitos (Rt) por sexo de T. lepturus da região de Porto Belo (SC) e respectivos diagramas de dispersão de resíduos. 

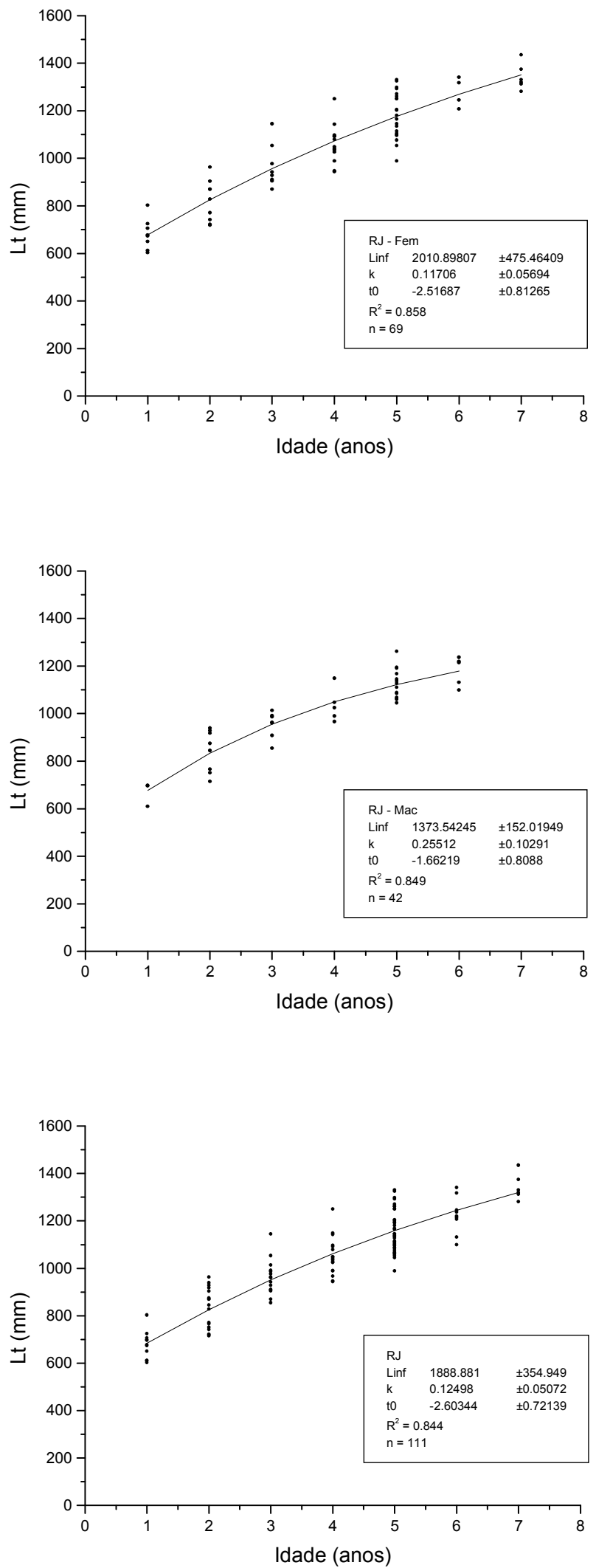

Figura 82: Curvas do modelo de crescimento de von Bertalanffy ajustadas aos dados do conjunto OtolTot de T. lepturus da região de Arraial do Cabo (RJ), por sexo e agrupados. 

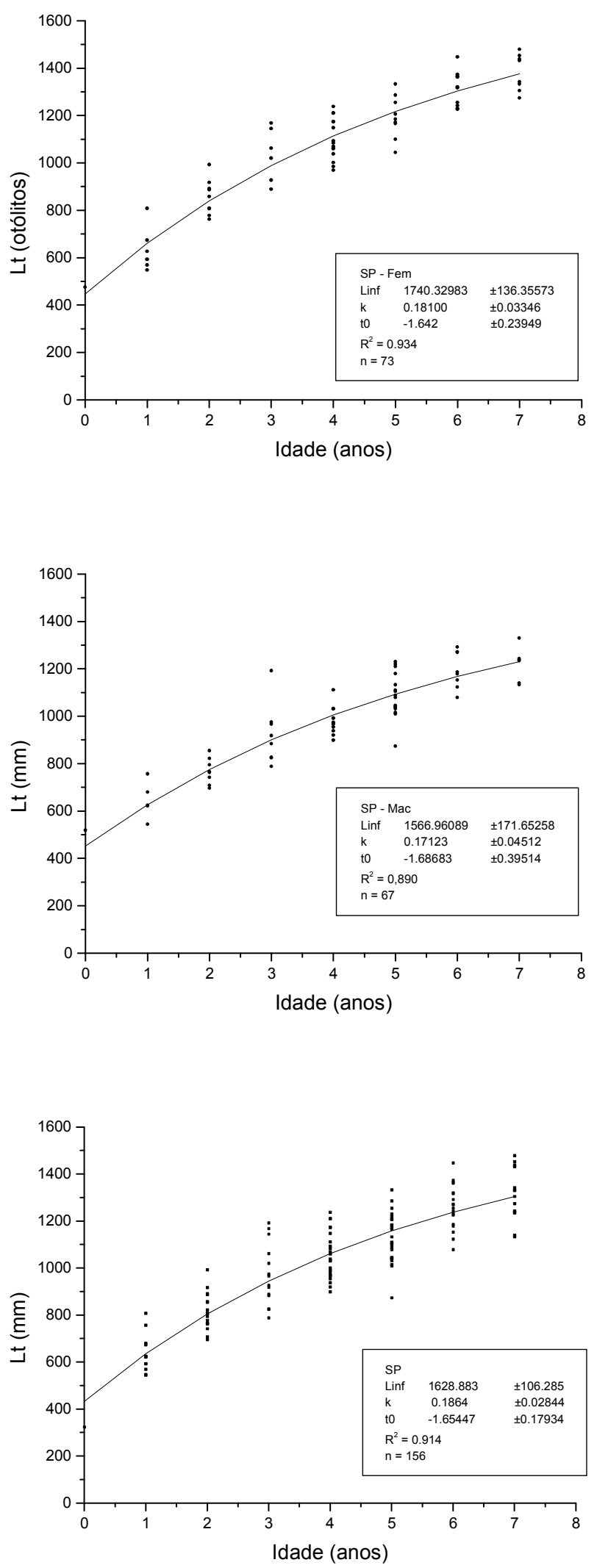

Figura 83: Curvas do modelo de crescimento de von Bertalanffy ajustadas aos dados do conjunto OtolTot de T. lepturus da costa de São Paulo, por sexo e agrupados. 

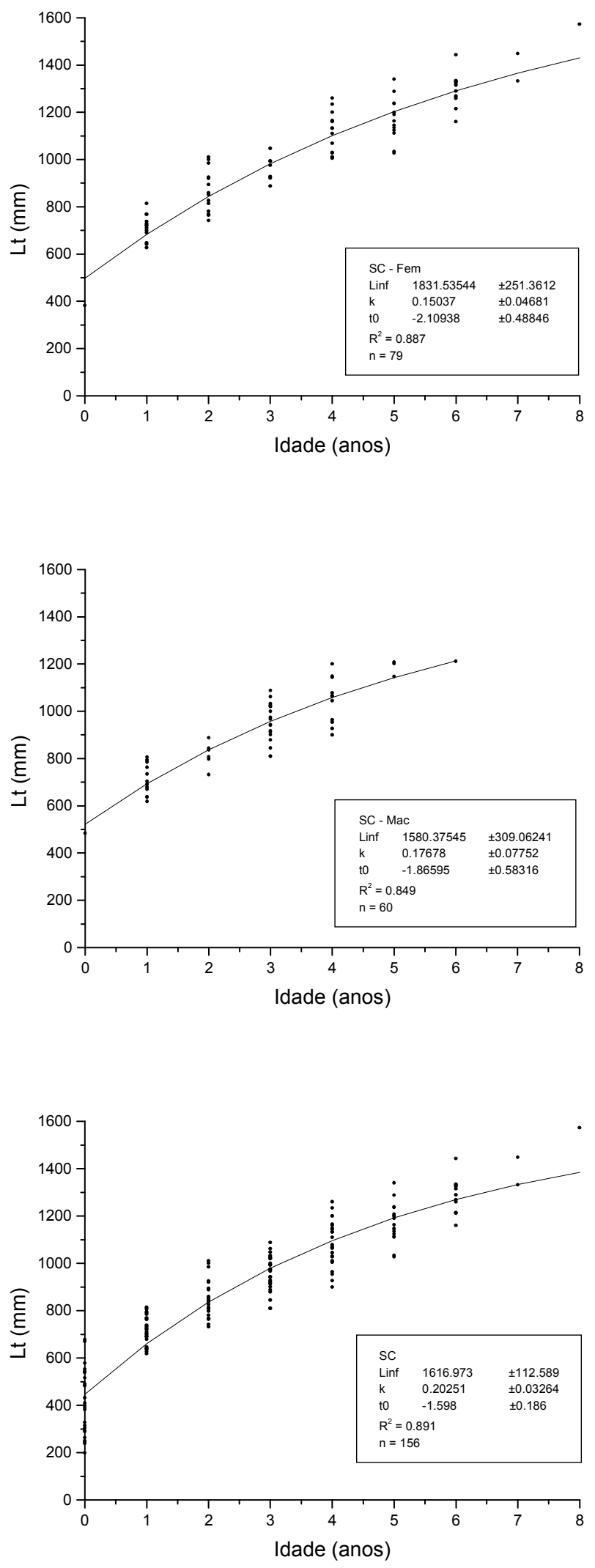

Figura 84: Curvas do modelo de crescimento de von Bertalanffy ajustadas aos dados do conjunto OtolTot de T. lepturus da região de Porto Belo (SC), por sexo e agrupados. 


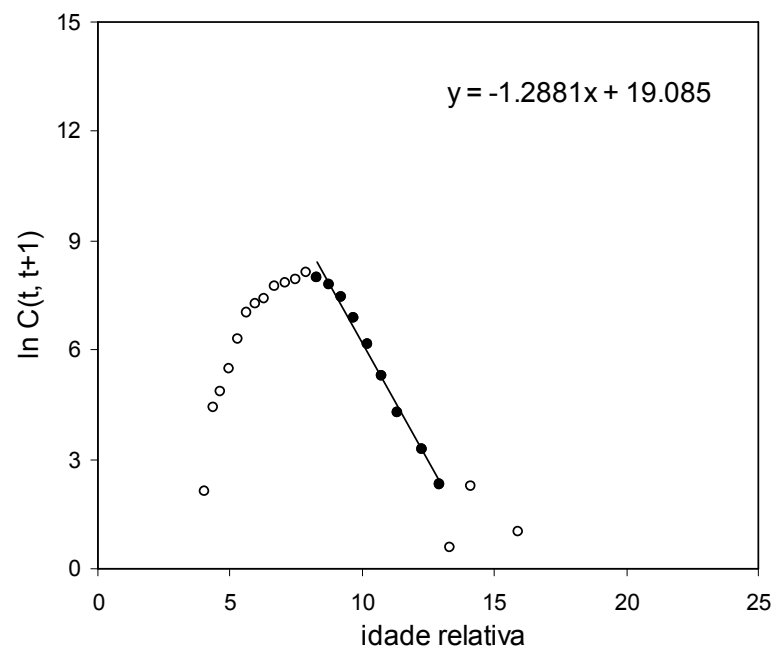

RJ

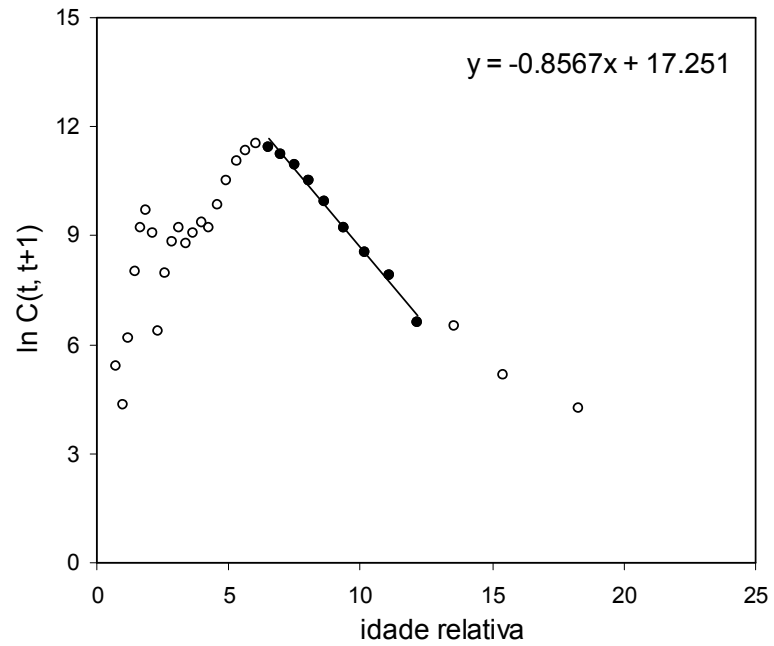

SP

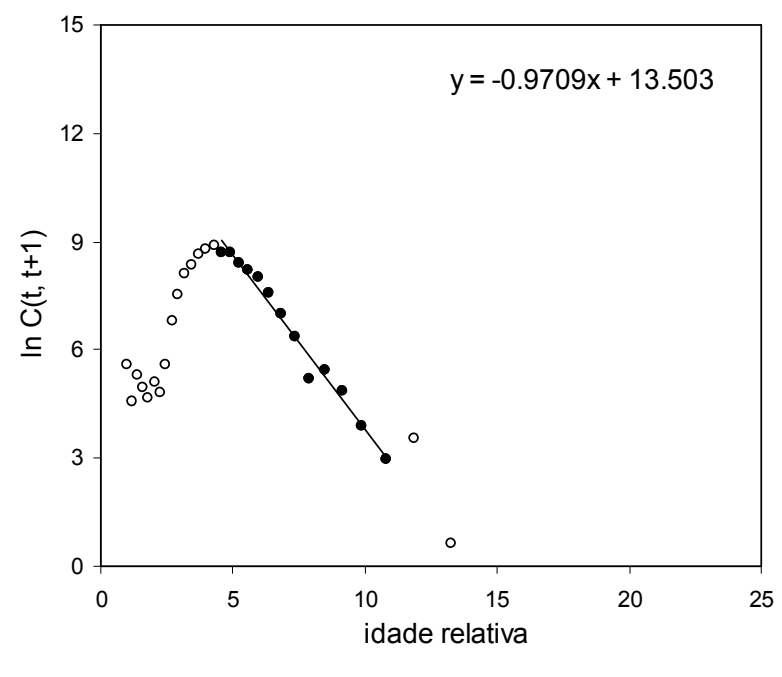

Figura 85: Curvas de Captura de comprimentos convertidos em idade de T. lepturus em cada Estado analisado. Os pontos em negrito foram utilizados na regressão linear. 

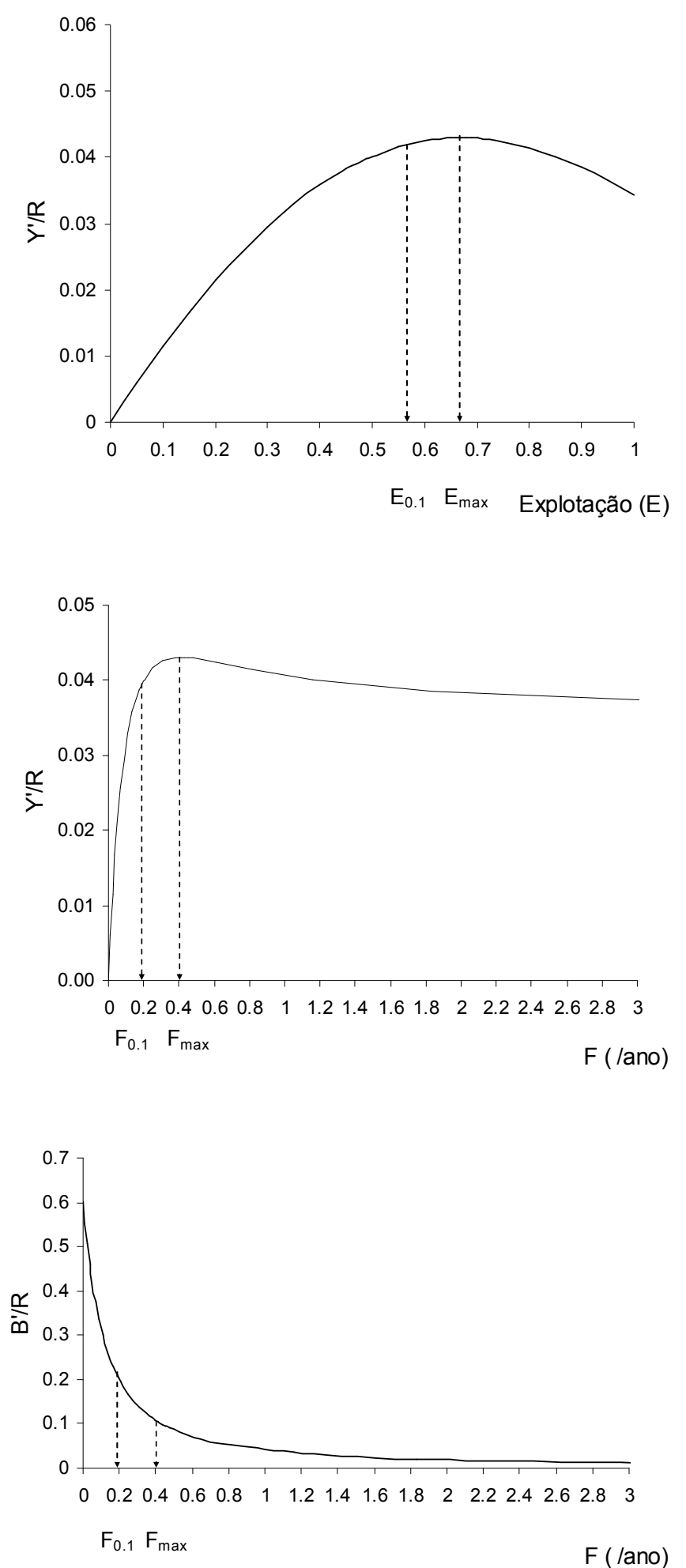

Figura 86: Rendimento relativo por recruta ( $\left.\mathrm{Y}^{\prime} / \mathrm{R}\right)$ em função das taxas de explotação (E) e mortalidade por pesca $(\mathrm{F})$; e biomassa relativa por recruta $\left(\mathrm{B}^{\prime} / \mathrm{R}\right)$ em função da taxa de mortalidade por pesca $(\mathrm{F})$ de T. lepturus da região de Arraial do Cabo (RJ), com indicação dos pontos de referência $\mathrm{E}_{\max }, \mathrm{E}_{0.1}, \mathrm{~F}_{\max }$ e $\mathrm{F}_{0.1}$. 

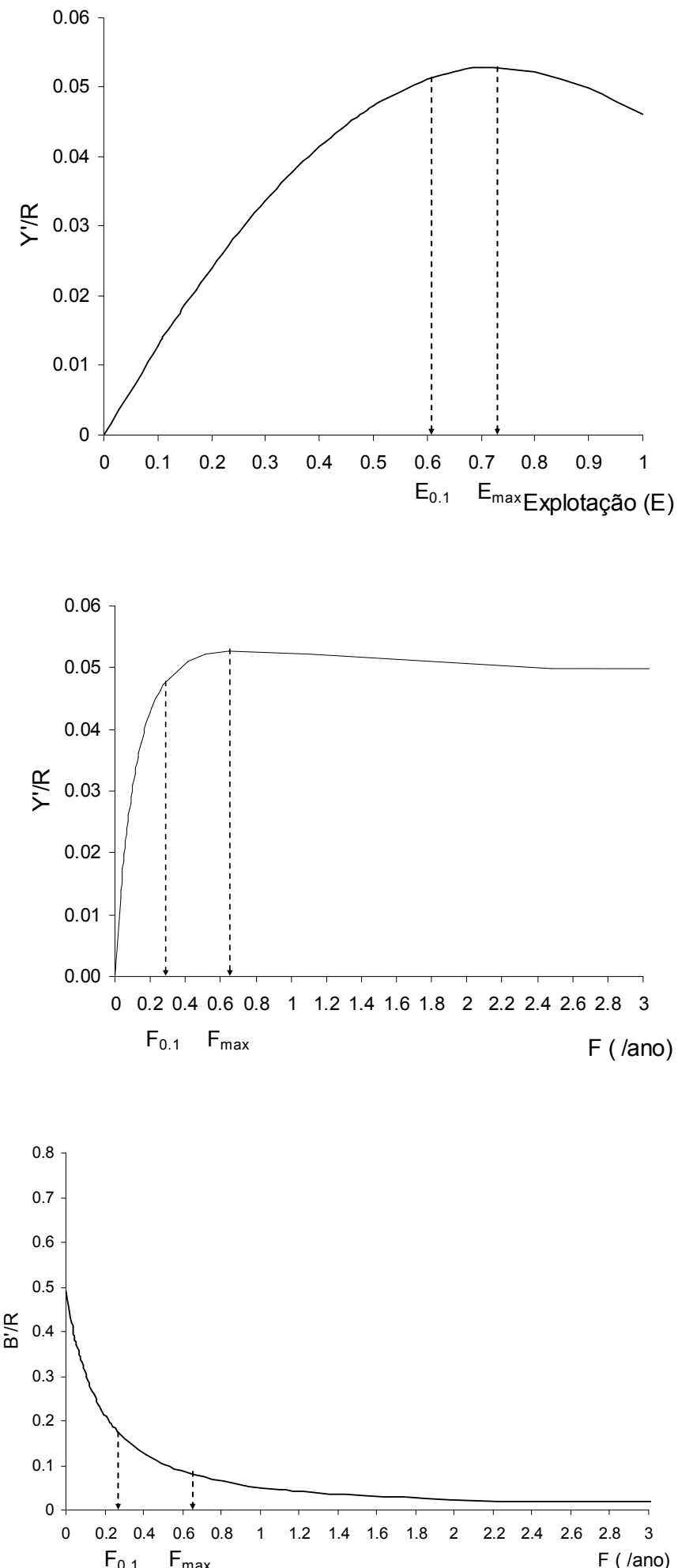

Figura 87: Rendimento relativo por recruta $\left(\mathrm{Y}^{\prime} / \mathrm{R}\right)$ em função das taxas de explotação (E) e mortalidade por pesca $(\mathrm{F})$; e biomassa relativa por recruta $\left(\mathrm{B}^{\prime} / \mathrm{R}\right)$ em função da taxa de mortalidade por pesca (F) de T. lepturus da costa de São Paulo, com indicação dos pontos de referência $\mathrm{E}_{\max }$, $\mathrm{E}_{0.1}, \mathrm{~F}_{\max }$ e $\mathrm{F}_{0.1}$. 

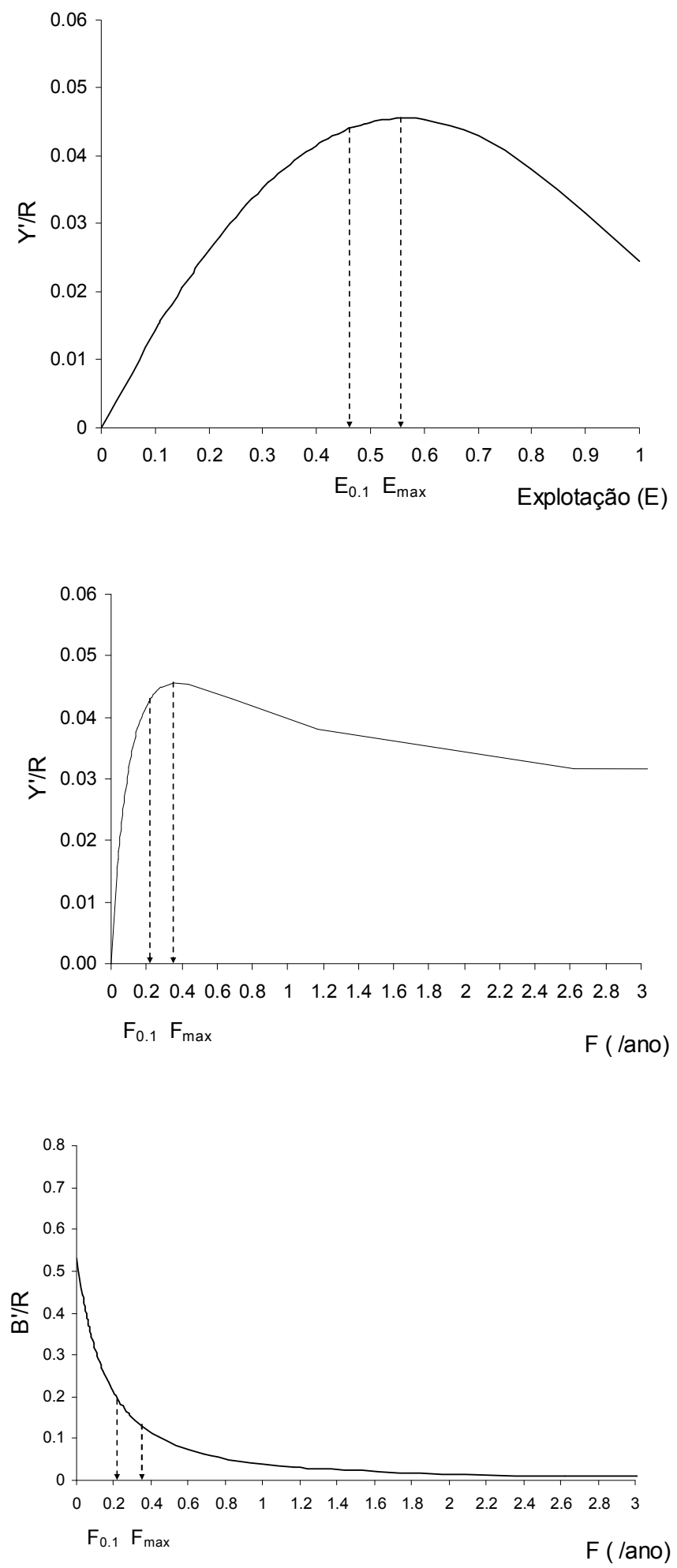

Figura 88: Rendimento relativo por recruta ( $\left.\mathrm{Y}^{\prime} / \mathrm{R}\right)$ em função das taxas de explotação (E) e mortalidade por pesca $(\mathrm{F})$; e biomassa relativa por recruta $\left(\mathrm{B}^{\prime} / \mathrm{R}\right)$ em função da taxa de mortalidade por pesca (F) de T. lepturus da região de Porto Belo (SC), com indicação dos pontos de referência $\mathrm{E}_{\max }, \mathrm{E}_{0.1}, \mathrm{~F}_{\max }$ e $\mathrm{F}_{0.1}$. 


\section{ANEXO I}

ENTRE SEXOS

\begin{tabular}{|c|c|c|c|c|c|c|}
\hline & RJF & RJM & SPF & SPM & SCF & SCM \\
\hline \multicolumn{7}{|c|}{ no. de raios da $2 a$. Nadadeira dorsal } \\
\hline \multicolumn{7}{|l|}{ Wt $x \mathrm{Lt}$} \\
\hline \multicolumn{7}{|l|}{ Lo x Lt } \\
\hline \multicolumn{7}{|l|}{ Ho $x \mathrm{Lt}$} \\
\hline Wo $\times$ Lt & & & & & & \\
\hline
\end{tabular}

ENTRE FÊMEAS

no. de raios da 2a. Nadadeira dorsal

L50

Fecundidade $\mathrm{x}$ Lt

Fecundidade $\mathrm{x} \mathrm{Wt}$

Lo $x$ Lt

Ho $x$ Lt

Wo $\times$ Lt

crescimento von Bertalanffy

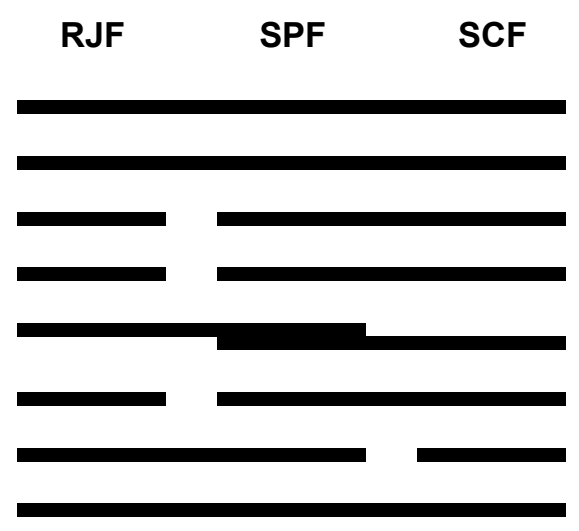

ENTRE MACHOS

no. de raios da 2a. Nadadeira dorsal

L50

Lo $x$ Lt

Ho $\times$ Lt

Wo $x$ Lt

crescimento von Bertalanffy

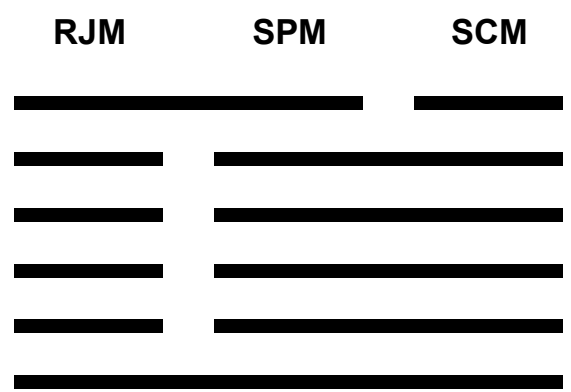

Anexo I: Diagrama das diversas comparações efetuadas entre os caracteres de T. lepturus obtidos nas amostras de Rio de Janeiro (RJ), São Paulo (SP) e Santa Catarina (SC), para machos (M) e fêmeas $(\mathrm{F})$. Wt - peso total, Lt - comprimento total, L50 - comprimento médio de primeira maturação sexual, Lo - comprimento do otólito, Ho - altura do otólito, Wo - peso do otólito. Esses resultados são conseqüência da aplicação do teste de comparação múltipla a posteriori (no. de raios da $2^{\mathrm{a}}$. nadadeira dorsal), ANCOVA (Lo x Lt; Ho x Lt) e razão de verossimilhança máxima (crescimento e reprodução). 